\title{
Waitangi Park: Public Land in Competition
}

\author{
A thesis submitted in partial fulfilment \\ of the requirements for the degree of \\ Master of Arts in Sociology
}

Nina Price

\section{Victoria University of Wellington 2009}




\begin{abstract}
This thesis looks at Wellington's Waitangi Park, through the specifics of the Chaffers Park Design Competition, in order to explore the repercussions mistrust can have on social vision and political response. In examining aspects of this competition over a piece of public land, and comparing various accounts of events leading up to it, an interpretative impasse is reached that factual explanations alone cannot minimise. Because the search for truth proves elusive, other forms of evidence must be relied upon as sources of knowledge. In this instance, an analysis of experiences demonstrates the effect differing expectations has on human interaction, ones that are shown to have a significant impact on placemaking processes and organizational structures. When debates over public land degenerate into power struggles, the issue of control is brought to the forefront of attention. It raises questions concerning who owns public land, whether it properly belongs to local authorities or the public itself. Who gets to designate how these spaces are used, and select what ought and ought not to go on these sites? Here, the issue of representation is troublesome because so many different groups claim to speak for the public's interest, leaving the reader wondering whose interpretation to believe and place trust in. Where the perception is that democratic rights are being undermined, then doubt in the principles underpinning consultation processes soon emerges. And once mistrust becomes entrenched, organizational tinkering is not sufficient in itself to reverse a negative state of affairs; only joint satisfaction will do. But if satisfaction proves unforthcoming, then a withdrawal from engagement can be anticipated as committed individuals quit the field in disillusionment. This in turn causes a narrowing of vision and leads to uncreative political responses - traits associated with acts of obliviousness.
\end{abstract}




\section{Acknowledgements}

I would like to thank Robin Boddy, Rachel Hughes, Simon Novak, Lindsay Shelton, Mary Varnham, and Rebecca Wilson for being willing to participate in this study, also for entrusting me with their recollections. I am much obliged to Chris Horne, Pauline Swann and Lyn Wilson for allowing me access to their personal papers; equally to the National Archives of New Zealand, the Turnbull Library and the Wellington City Council Archives for their assistance in retrieving archival material. To my academic supervisor, Dr Mike Lloyd, thank you for the sustained support. As well, I would also like to extend my appreciation to Victoria University of Wellington for granting the scholarship that made this research possible. 


\section{Contents}

Page

Abstract......................................................... ii

Acknowledgements............................................

Preface..................................................... $\quad \mathrm{V}$

Introduction and Framework...................................... vi

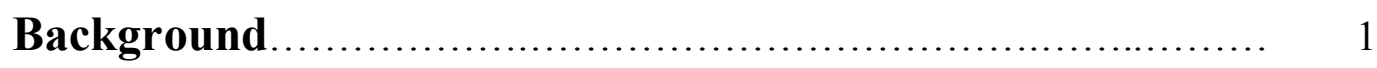

Telling the story..................................... 2

First Evaluation.................................. 44

Middle Way ................................................ 46

From the Ideal to the Unmentionable.................... 47

Acknowledging Anomalies.......................... 62

Second Evaluation................................. 74

The Literature........................................ 76

Third Evaluation............................................ 92

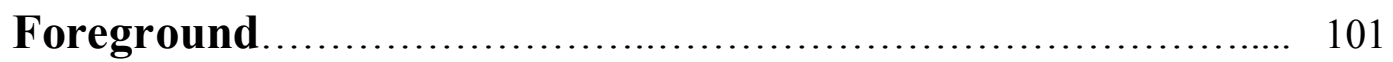

Re-envisioning Waitangi Park:

As a presence................................ 102

As a place of transformation..................... 107

As a space of obliviousness.................... 112

Unfinished Business............................................ 115

List of Illustrations.............................................. 117

References....................................................... 132 


\section{Preface}

It would be nice to think that this study was capable of jumping the barrier between disciplines, of extending knowledge in such a way as to resolve conflicts arising from mutual doubt. Certainly the concerns raised here remain far too complex for any one discipline to solve on their own. However, the idea of moving across different fields in the pursuit of solutions has proved more fraught than anticipated. So a word to the unwary, when contemplating crossing boundaries into unfamiliar territory:

Be sure of your starting point before setting off;

Tell someone of your intentions;

Pick a bearing and stick with it;

Be realistic about what can be accomplished;

When at risk of getting lost, head for higher ground;

For every leg of the journey, write up an evaluation. 


\section{Introduction and Framework}

Because of its unusual framework, this thesis requires a bit of explaining so that the reader will know what to expect. It has been divided into three sections: a background, a middle-way, and foreground.

The background provides a brief history of the Chaffers site, then launches into the story of how Waitangi Park was created through intense public lobbying. This account is told by two lobbyists: Lindsay Shelton, past president of Waterfront Watch and Mary Varnham, instigator of 'Chaffers Park - Make it Happen'. Both these lobby groups fought for an open, green space on public land set down by Wellington City Council for redevelopment as private townhouses and commercial retail outlets, with only a small allowance for a pocket-sized park. The story of the Chaffers Park Design Competition is recounted by Rachel Hughes, Simon Novak and Rebecca Wilson, part of the team of designers responsible for Scheme D proposal which gained the public's favour but failed to win, coming in runner up. Rounding off these reminiscences, Robin Boddy recalls taking part in the Wellington Civic Trust's Harbour City Competition, held in 1982/3, which kicked off redevelopment plans for Wellington's waterfront.

Their version of events is presented as a separate tableau in order to accomplish two things: first, to distinguish and preserve an account that few are aware of; second, to demonstrate a shift in the public mood from a state of hopefulness, and dynamism, to one of deep distrust in Wellington City Council's vision for the waterfront and Chaffers area. How over a span of twenty years, a conflict emerges due to unresolved issues which were associated with consultation and implementation practices, culminating in two particularly fraught periods, those of 1996-1998 and 2000-2002. In the first evaluation, which follows this joint narrative, the fairness of the design competition is brought into doubt, as is its overall effectiveness as a tool for public consultation.

In the second section of the thesis, entitled middle-way, an attempt is made to balance the first negative version of events with a more positive one as offered by Wellington City Council. This account is backed by the winners of the competition, as well as design professionals who fully endorsed the process behind Council's design selection for the park. From there, another version of the story is presented, this time that of local newspapers where a series of consecutive headlines is used to trace political events. The City Voice's account is shown to be strongly biased against Council, with Wellington's daily newspapers tending to play one side of the debate off against the other, as the mood suits. This juxtaposition, in such close quarters, of conflicting accounts makes the truth of the situation hard to discern, leading to an 'interpretive impasse or moment of undecideability’ (McQuillan 2001:87) (De Man 971).

The literature review further compounds matters by offering a scholarly perspective on issues pertaining to design competitions and procurement processes. These readings undermine the principles and structures underpinning the Chaffers Park Design 
Competition, and lend credence to the allegations made in the first version of the story. An examination of the role of lobby groups in democracies is also somewhat destabilising, as the impact of negative place-making experience on social vision and political response becomes clearer. In examining place as a process, the notion that social ties and levels of engagement have a significant effect on the meaning of sites is discussed, leading to a better understanding of the politics behind public parks. Here, the function of recreational spaces is looked at over different historical periods, culminating in the most recent of inventions, the 'cultural park', of which Waitangi Park is a prime example. A review of a similar waterfront redevelopment project, one built in Bristol, England, highlights some of the negative outcomes this city experienced, suggesting that certain land-use problems are not only foreseeable, but highly predictable. The second evaluation discusses the implications, relating these findings back to Waitangi Park and the Chaffers Park Design Competition.

In the last section of this thesis, entitled the foreground, a confrontation is forced between fact and speculation resulting in Waitangi Park being explored in three new ways: as a presence, as a place of transformation, and as a space of obliviousness. Because this version of the story is written from a more unfettered position, the problem of bridging between different sections becomes acute. Readers must be prepared to take a leap of imagination and cross over into unfamiliar territory where absences become presences. In going back over the site's transformation from a busy port to an obsolete facility, one phase of its history is traversed moving us closer to the park's present function, necessitating a fraught journey through a landscape of competing interests. Who will be the ultimate winners, and losers, in this adventure? One of the main victims of this conflict is Waitangi Park itself, coming off second best in a battle that pits makers and users against each other. If it can be shown that this new park has produced nothing unique in terms of new partnerings, or governance practices, then we are faced with an impoverished and unloved site that will never achieve an iconic status. After reading these conflicting accounts, Waitangi Park looks less benign than before, making us wonder whether knowing about the debate surrounding it helps, or hinders, our enjoyment of this space.

In terms of what makes this case study sociological, it has been selected primarily as a result of the perplexing methodological issues it throws up that are associated with noticing, recalling and reporting. Its use has necessitated the sorting of facts from speculation, as well as objects from events, making for an unorthodox framing. The presence of so many visuals is used as another source of knowledge, one that helps in making comparisons and brings to life other visions for Waitangi Park that would otherwise be forgotten. These images serve to illustrate events and describe designed environments, forming another colourful narrative option that is not commonly used in Sociology. Through a close examination of these, the reader will come to understand how useful visuals can be in terms of envisioning new identities and behaviours, as well as smoothing over anomalies. How design serves, on occasion, to sideline attention away from harder to resolve political and social issues, leaving only the more easily resolved concerns behind for the qualified professionals to sort out for us. 
No methodological report is offered in this thesis, the story and evaluations being selfexplanatory. All the participants are identifiable personalities, meaning that their interviews have been conducted on a non-confidential basis with their consent and that of the Victoria University of Wellington's Ethics Committee who approved this procedure. Interviewees were given the opportunity to amend their version of the story until it met with their approval, a step I considered warranted given the complexity of events. The rest of the data, being available in the public domain, has been obtained through a combination of literature and archival searches with additional material being sourced from private collections.

Because of a growing interest in place-making practices, the selection of an urban park as a topic of research is not that uncommon for Sociology. At Honours level, I wrote a paper entitled, 'Waitangi Park: Setting the Context', in which the site was looked at as an object, an idea and as an object-lesson. Here, findings suggest it takes careful scrutinising to understand that objects, in themselves, cannot to tell us what a park ought to do 'for' us; likewise, ideas alone are insufficient to explain the user's experience of a park. That it requires a combination of both objects and ideas to get the full picture, or measure, of any place. And unless this awareness is fully grasped and acted upon, we are likely to find ourselves condemned to a life torn between fact and wish, with our expectations always at odds with experience (Huxley 1961:29).

This act of breaking through Waitangi Park's surface gives a greater appreciation of the motives behind utility, making discernable aspects of procurement and implementation practices not normally made visible to the layperson. Further, in becoming aware of the behind the scene politics of this space, we get some idea of how collective memory is shaped, particularly through the manipulation of official historical accounts. This is probably the most striking observation to come out of this study, especially the ease with which countervailing interpretations are obliterated through the reinterpreting of events by prevailing interests. If anything, stumbling across these conflicting stories made me realize the importance of preserving alternate versions of events, as a way of counteracting an obliviousness to place-making practices in urban environments. I wanted to unsettle the notion of park patrons as passive spectators and promote better models of engagement.

Because this study deals with a conflict over public land, it will be of interest to sociologists working in the areas of space use, place-making, and land-use problems. It may also attract the attention of anthropologists, planners, urban designers, architects, landscape architects, and urban geographers. Since design is far from being a value-free enterprise, because it has close ties with social and political circumstances, the occasional hiccup thrown up by redevelopment projects makes for interesting research topics. Since some of the concerns raised tend to re-emerge, time and again, an exploration of land use problems is timely particularly in relation to sustainability issues. Furthermore, in considering how to reverse mistrust once entrenched, the need for more open dialogue becomes imperative, hence this foray into an embattled landscape. Not to enquire into these matters condemns the public to remain bit part actors in their own environments, an unenviable position that I would like to see rectified if at all possible. 


\section{Background}

Background refers to that which lies behind, or at the back, of an object of contemplation. Although taking up a background position affords a certain level of obscurity and safety, there is every chance of being overlooked in the process of doing so. 


\section{Telling the Story}

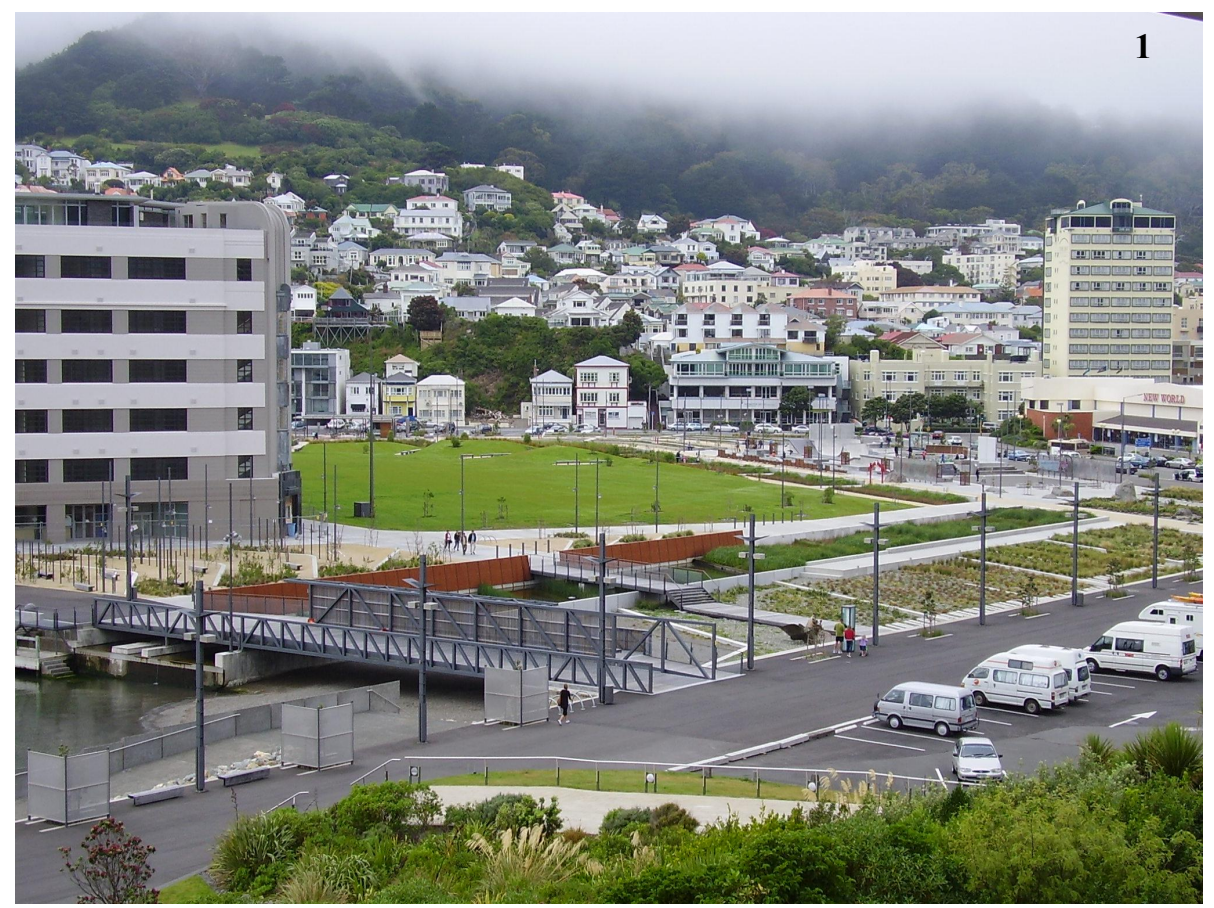

This story tells of how two small lobby groups battled their local Council to get an open, green space on a piece of public land. It is also the tale of a two-staged competition process held to select a design for the park, as recounted by the runners up in this event. 


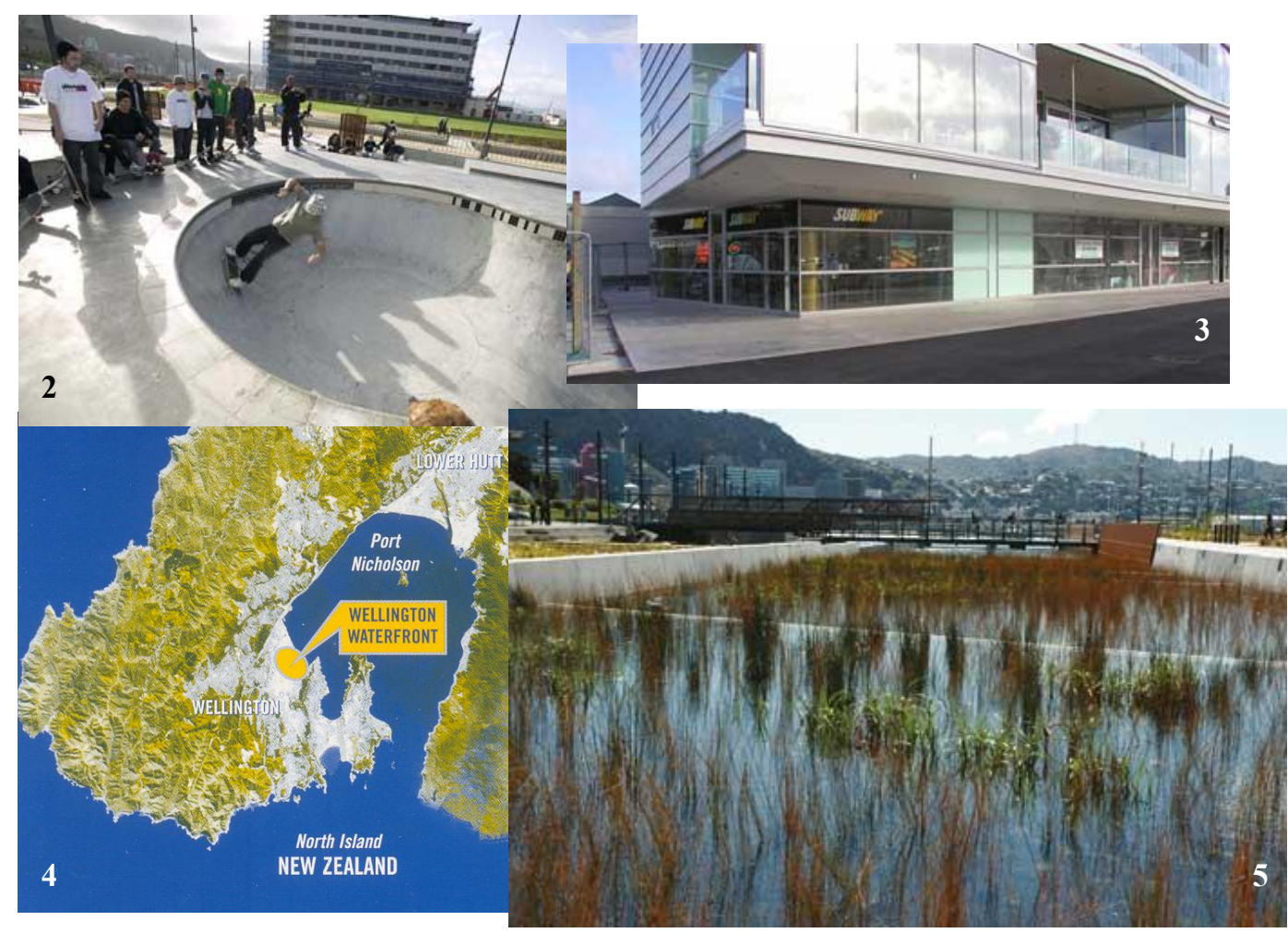

For those of you unfamiliar with Waitangi Park, it is located at the southern end of Wellington Harbour. This area of the capital has been undergoing revitalization over the past 15 years as have numerous other cities with waterfronts. In terms of its design, Waitangi Park follows a current trend whereby former industrial sites are being redeveloped into urban playgrounds. The park has won its joint designers, Megan Wraight, of Wraight and Associates Ltd, and John Hardwick Smith, of Athfield Architects, both national and international recognition ${ }^{1}$.

${ }^{1}$ Wellington City Council, On the Waterfront, Issue 29, April 2007.

'Waitangi Park wins architectural award', The Dominion Post, 29 May 2007. 


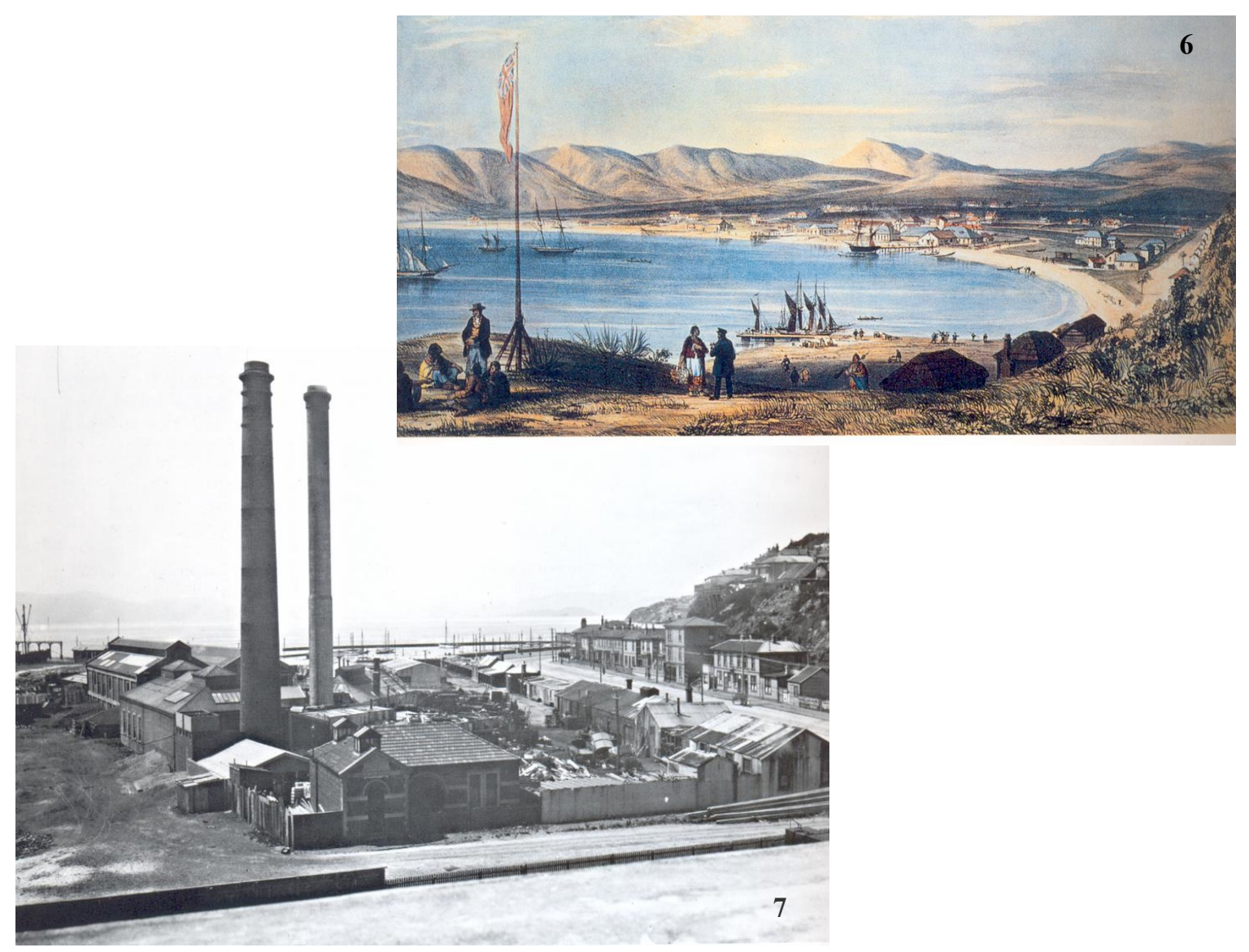

Knowing a few background facts about the site is helpful for setting context. In precolonial times, a Maori Pa existed in the vicinity of Waitangi Park whose inhabitants were displaced by the arrival of British colonists. Initially, the settlement of Port Nicholson consisted of military barracks and only a few private dwellings along the foreshore. In 1855 , an earthquake uplifted the area by 1.5 metres thereby destroying a steep bank that impeded growth. With its disappearance, commercial and wharfing activities were stepped up eventually making the area an industrial hub. Its capacity for growth was further enhanced by a series of sea reclamations that changed this once sleepy fishing village into a bustling township. The site went on to house an enormous trash incinerator, dubbed 'the Destructor', as well as the city morgue and dog pound. The open spaces that remained on the site were slowly engulfed by a sprawling City Corporation Yard from which city services operated, such as engineering workshops, maintenance crews, garages, laboratories, transport yards and the like ${ }^{2}$.

2 (Yska 2006:80-83) (McGill 2003:25) (Ward 1975: 304,306) (Davies 1994:4) (Roberts 1989:6-10) (Wellington Harbour Board 1980:9). 


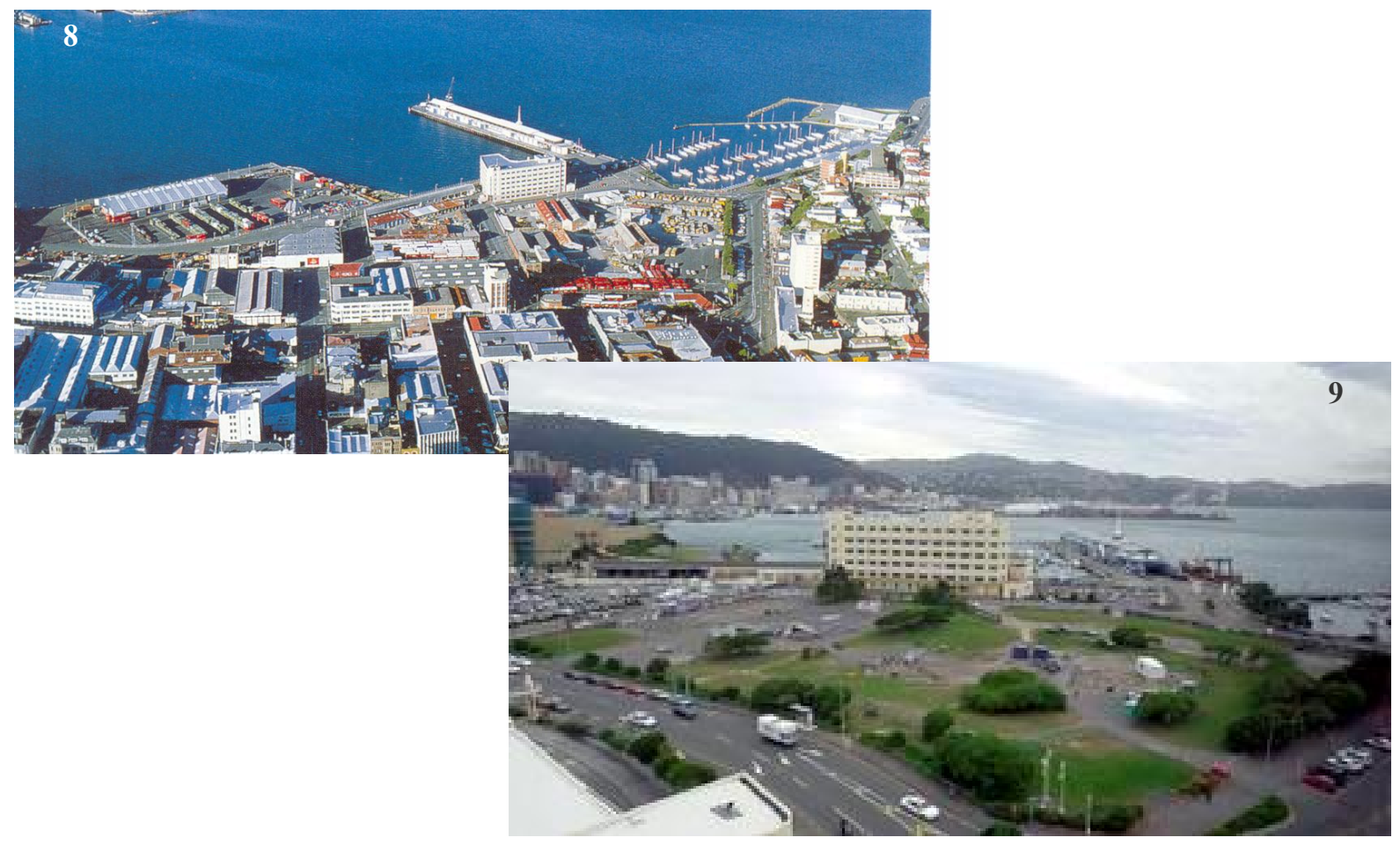

During the 1930's, the Herd Street Post and Telegraph Building was erected as part of a plan to beautify Wellington's gateway. This art deco building, designed by Edmund Anscombe, made provisions for a public park in its ground that unfortunately were never realized. Nor did a vision for grand avenues, creating view shafts from the city down to the waterfront, ever come to fruition either. By the late 1970s, Wellington's port facilities were in the process of being shifted across the harbour, a move that led to the gradual demolition of the City Corporation Yards. This left behind a vacant lot upon which a temporary park was created. In spite of its unsightliness, Wellingtonians were grateful for this open, green space because so few existed in the central city. The area became known as Chaffers Park after Edward Main Chaffers, one of Port Nicholson's founders and its first harbourmaster ${ }^{3}$.

\footnotetext{
3 'Clyde Quay Area: Improvements Effected and In Prospect', The Dominion, 11 November 1937. 'Corporation Yard Move Would Free Six Acres of Valuable Land', The Evening Post, 11 June 1957. 'Eyesore Soon May Go', The Dominion, 13 February 1965.

'Big Redevelopment Plan for City Council's Yard in City is Approved', The Evening Post, 17 August 1972. 'City plans \$40m. facelift for three acres', The Dominion, 28 June 1978.

(Wellington Harbour Board 1980:9)

(Edwards 1989)
} 


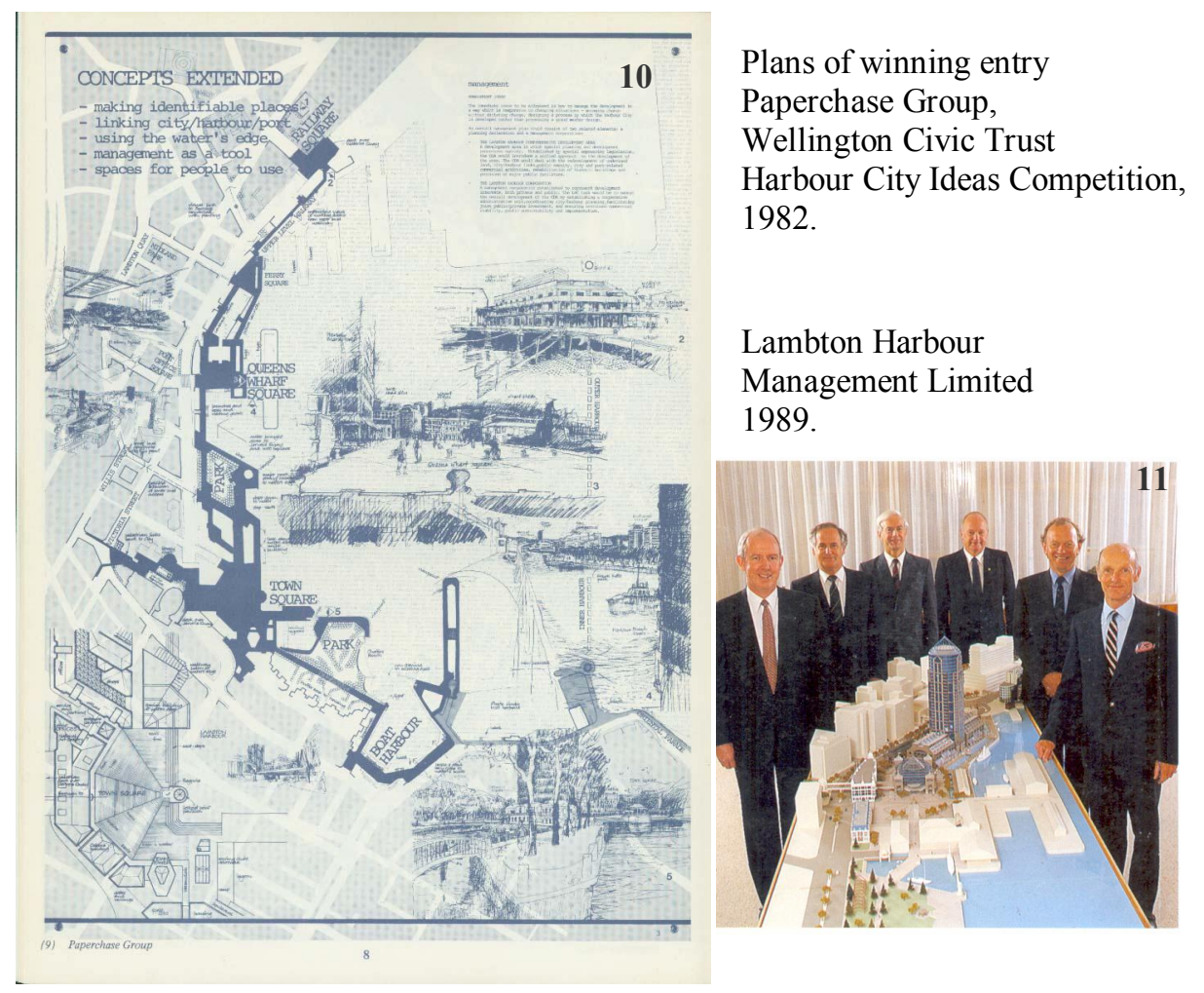

As early as 1978, a public opinion survey was conducted in order to gauge what direction harbour development should take, also to measure the extent of public interest in this sort of project. Response showed two major areas of concern: the preservation of unique features and the need for revitalization of the area. At the time, the public mood for this project was hopeful and dynamic. In 1982, Wellington City Council and the Harbour Board sponsored the Wellington Civic Trust, a lobby group, to organise a public competition. Its task was to create a redevelopment scheme through a 'Harbour City Ideas Competition', an event where everyone was encouraged to participate. In the competition's first phase, ideas were captured and fed through to architects who, in phase two, were expected to incorporate them into their own concepts. The core philosophy behind this process revolved around a $60 \%$ retention of open areas along the harbour, the only proviso being that these spaces be self-funding. This was an unusual principle that would prove troublesome in times to come. The Paperchase Group won this competition by coming up with an innovative vision as well as a management structure for the redevelopment - something none of the other entrants had thought to do. However, due to the 1987 stock market crash, few of their plans would come to fruition save for the idea of a wide promenade along the length of the waterfront ${ }^{4}$.

\footnotetext{
${ }^{4}$ Action for the Environment (1978) A Harbour View: A Public Opinion Survey of Wellington. Wellington Civic Trust (1982/3) Harbour City: New Ideas for One of Wellington's Finest Assets. Wellington Civic Trust (1983) Harbour City: Blueprints for the Future; Winning Entries in the Wellington Civic Trust Harbour City Competition.

Assessors' Report: Harbour City Competition, New Zealand Architect, No. 5, 1983, pp.35-41. Wellington Civic Trust (1984) Harbour City Ideas For Action: Proceedings of the Harbour/City Conference, 4-5 July 1984.
} 
12

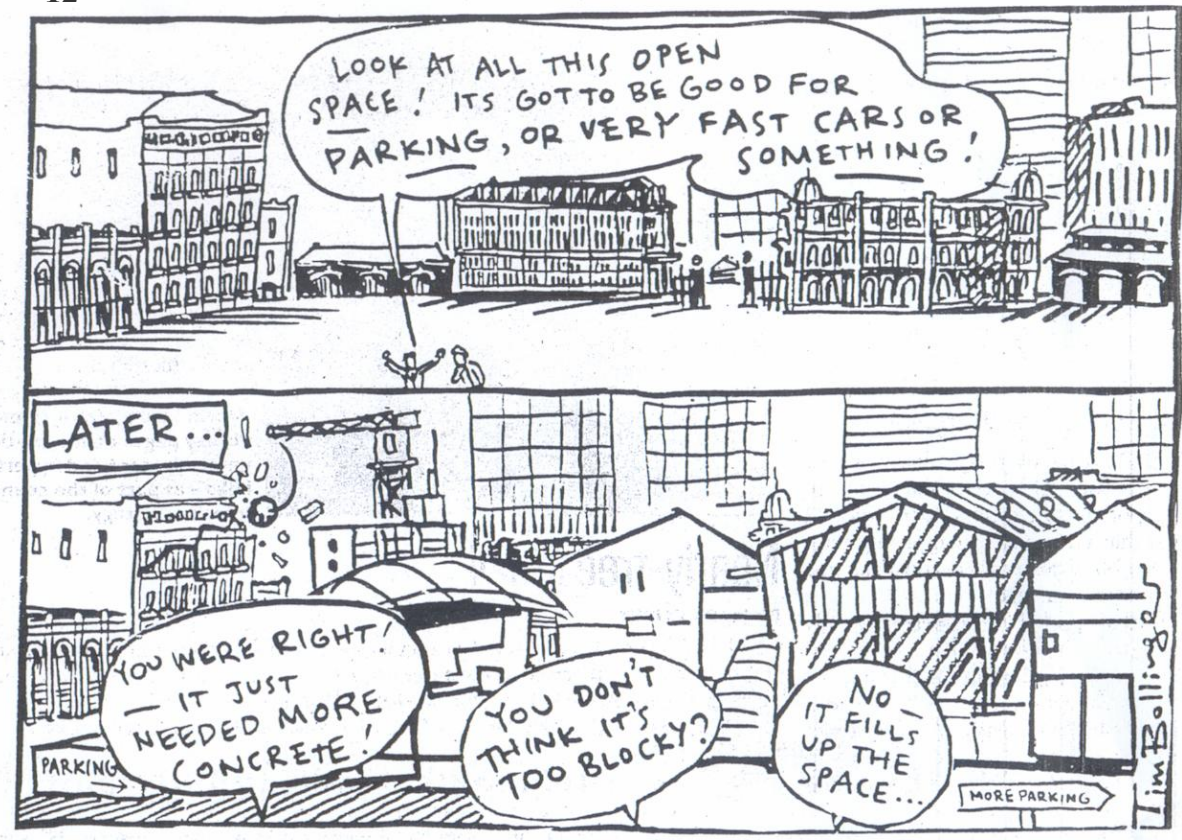

In spite of this economic downturn, Wellington City Council was still able to proceed with a number of schemes. These included the development of Frank Kitts Park, a lagoon and boat shed, renovations to a small number of historic buildings along Queens Wharf, turning old warehouses into restaurants, as well as the construction of a marina near Chaffers Park. As this cartoon suggests, the initial enthusiasm for these changes was dampened somewhat by the reality of seeing them built. The foreshore was changing so rapidly, and in what must have appeared such an unregulated fashion, that the public was justifiably upset. Their vision of the harbour was at odds with Council's, particularly over its use for car races and as the potential home of an unwanted casino $^{5}$.

\footnotetext{
5 'Right questions not asked', Contact, 25 August, 1989.

Lambton Harbour Management Limited (1989) Lampton Harbour Development Project. Lambton Harbour Group (1989) Lambton Harbour Combined Scheme: Under Town and Country Planning Act 1977: Appendix: Urban Design Concept.

Lambton Harbour Management Limited (1990) A Place for People: Lambton Harbour Development Moves into the 1990s.

'A non event?', City Living, 7 December 1995.

'Casino's long game of chance begins', The Evening Post, 1 April 1996.

'Update on Lambton Harbour', Wellington City Council, May 1996.
} 


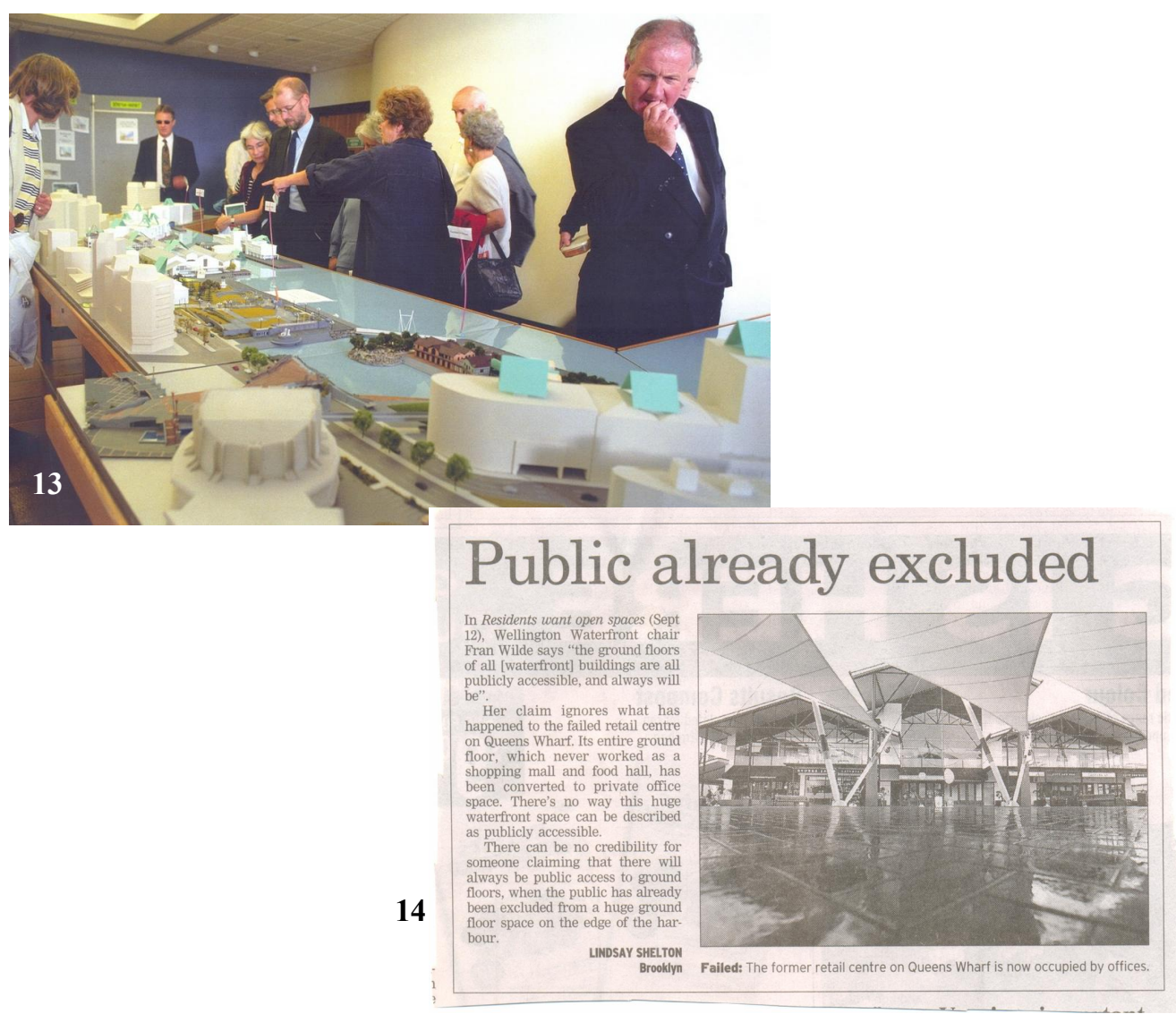

With the erection of the Queens Wharf Retail and Events Centre in the mid-1990s, the mood turned decidedly hostile. Even the architects were unanimous in condemning what they saw as examples of appalling redevelopment, as were newly formed lobby groups, indignant at the way the public was being excluded from decision-making processes. The call went out for Council to adopt more transparent and inclusive procedures. In response, a Community Consultative Committee was established whose function was to review waterfront development and interact closely with the public ${ }^{6}$.

\footnotetext{
${ }^{6}$ Wellington Civic Trust (1996) On the Waterfront: A Report and Commentary of the Lambton Harbour Forum.

'Thinking big on the harbour', The Dominion, 15 and $16^{\text {th }}$ May 1996 [commentary by Lindsay Shelton]. Community Consultative Committee (1996) Report on Lambton Harbour.

Community Consultative Committee (1997) Public Consultation on the Waterfront Designs.

'Wellington's waterfront - a vision betrayed', City Voice, 26 June 1997 [commentary by Derek Wilson].

'Creed of the cancer cell', City Voice, 3 July 1997 [commentary by Derek Wilson].

'The state of our civilisation', City Voice, 10 July 1997 [commentary by Derek Wilson].

'Getting Lambton Harbour back on track', Wellington City Council, Special Lambton Harbour Consultation edition, July 1997.

'Public already excluded', The Dominion Post, 15 September 2007.
} 


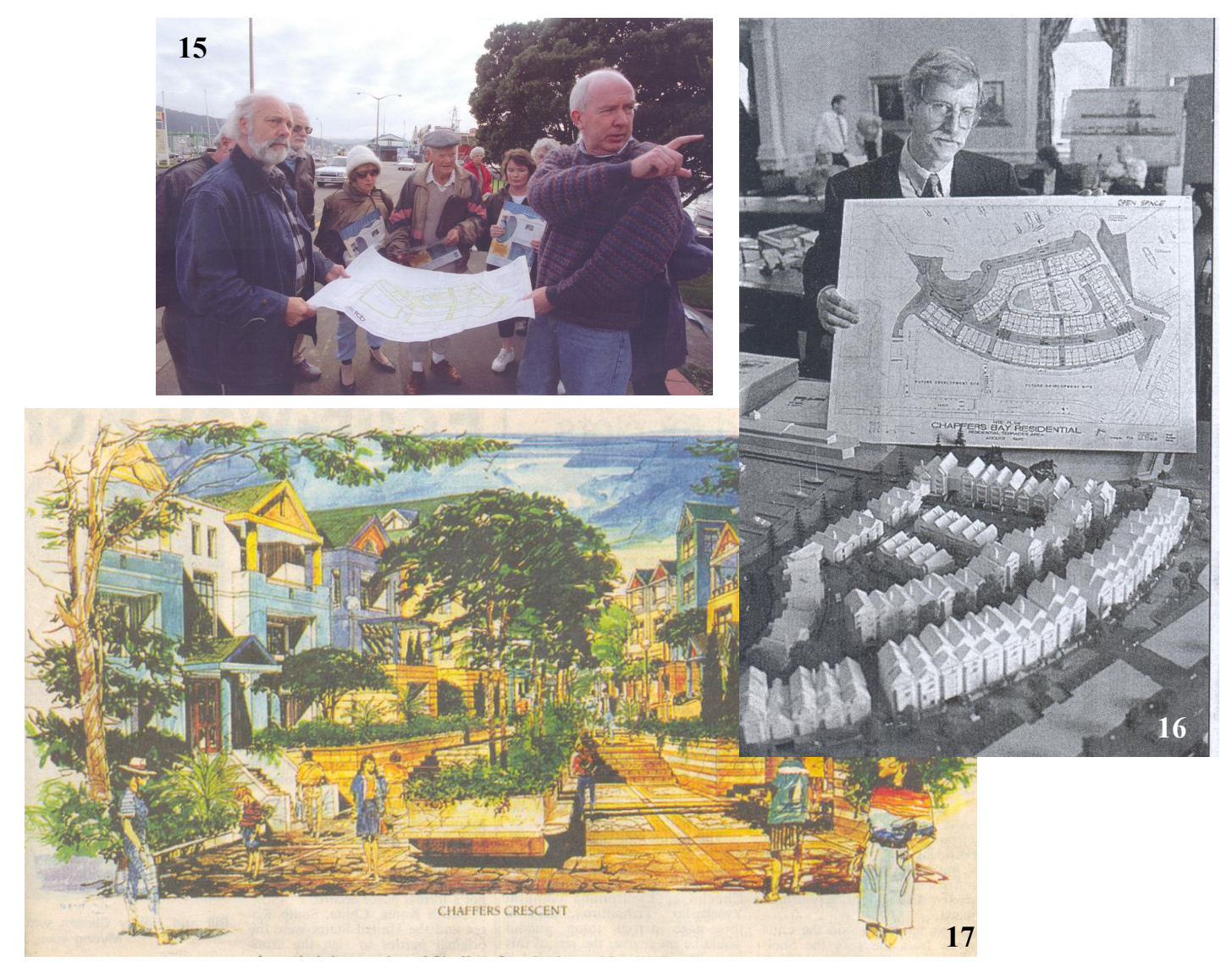

Groups, like 'Waterfront Watch' and 'Chaffers Park - Make It Happen', had begun taking matters into their own hands, suspicious of Council's motives. One of its plans, announced in April of 1996, was to turn Chaffers Park into an estate housing 700 people along with retail outlets and a pocket-sized park. This was an idea modified from the 1983 design competition which, at the time, had seemed like a reasonable use of the land. However, for a long time Wellingtonians had wanted a public park on the Chaffers site, an opportunity that they now saw slipping away with the privatization of this public land ${ }^{7}$.

\footnotetext{
7 'Clyde Quay Area: Improvements Effected and in Prospect', The Dominion, 11 November 1937.

Letter from Winifred E. Wright to Mayor of Wellington, 29 May 1964. Wellington City Archives, File: 00009:953:50/3/13 Pt 1, 1933-1965.

'On the Waterfront', The Dominion Weekend, 18 November 1995.

'Integrated view of Chaffers Bay plan urged', The Dominion, 17 April 1996.

'Parts of the development will be unpleasant for public - report', The Evening Post, 18 April 1996.

'A space to play?', City Voice, 18 April 1996 [commentary by Simon Collins]

'Informed debate welcomed', City Voice, 9 May 1996 [commentary by Malcolm Woods, Chairman of Lambton Harbour Management].

'A foundering flagship', City Voice, 16 May 1996 [commentary by Chris McDonald].

'Another look at waterfront', The Dominion, 21 May 1996.

'Lambton Harbour mismanagement', City Voice, 8 August 1996 [commentary by Alastair Thompson].
} 


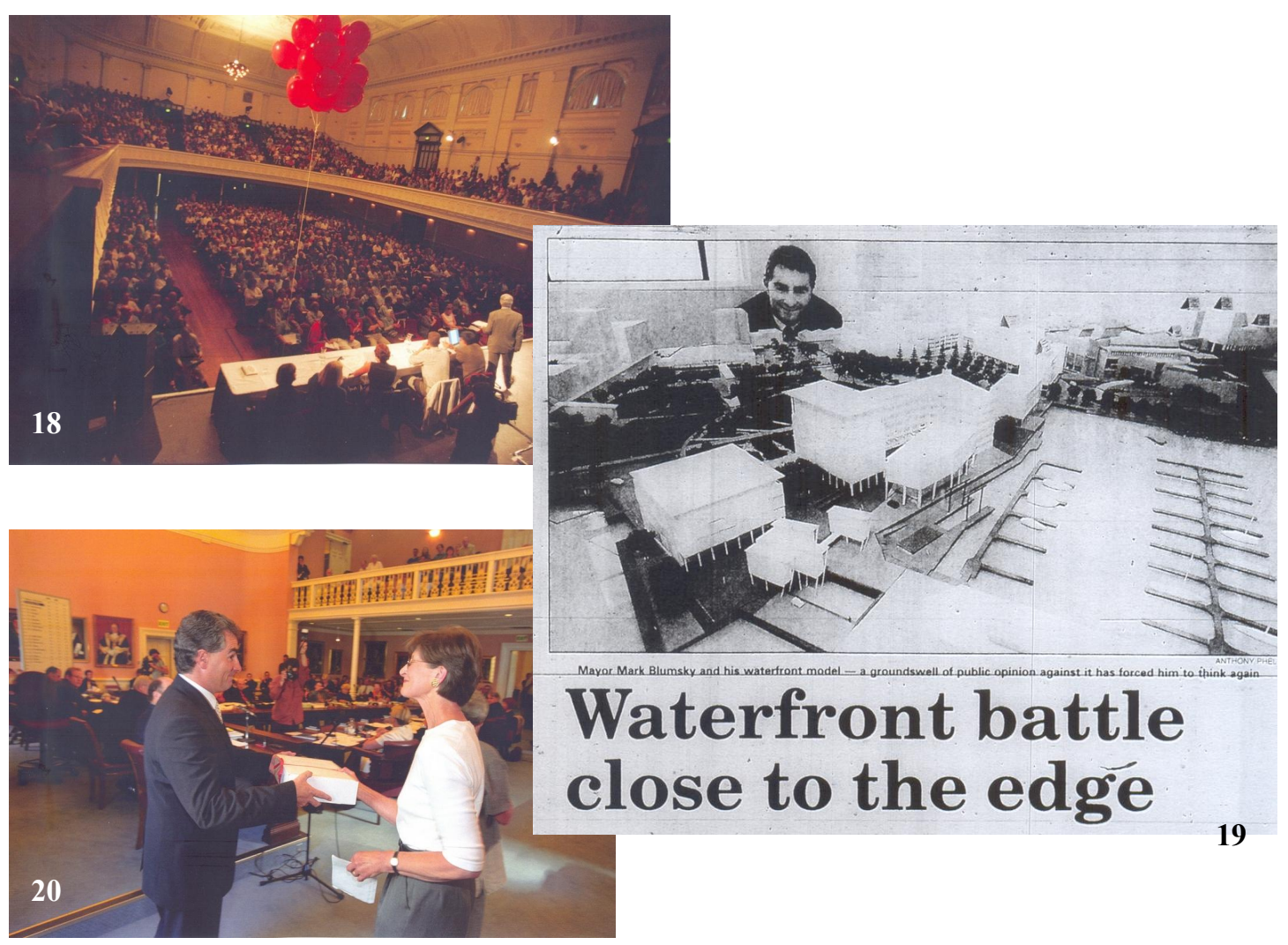

Then Wellington Mayor, Mark Blumsky, was eager to see this development go ahead and failed to account for the strength of public sentiment on the matter. In large and confrontational meetings, Blumsky was faced with a barrage of opposition over his plans for the site. Two months after a noisy gathering in May of 1996, a petition with 10,000 signatures was presented to Council which opposed schemes for large new buildings along the waterfront's edge. Eight hundred people attended this meeting called by Lambton Harbour Management, where the public voted in favour of keeping the Chaffers area free of buildings. The crowd made its message abundantly clear: a 100\% open, green space with no new buildings was wanted ${ }^{8}$. In response, Wellington City Council placed a moratorium on development, which was an unprecedented move, and undertook a review of its waterfront plans instead.

\footnotetext{
8 'Time to pause - Blumsky: Wellington Waterfront Forum', The Evening Post, 20 May 1996.

'The common theme: put people first', The Evening Post, 28 May 1996.

'New waterfront plan almost ready', City Voice, 27 March 1997 [commentary by Simon Collins].

'Attack on Lambton planning', The Dominion, 13 May 1997.

'Lambton Harbour: Decision time', City Voice, 17 July 1997 [commentary by Ian Hunter, Chairman, Wellington Civic Trust].

'Council votes for buildings on Chaffers site', The Dominion, 5 March 1998 [commentary by Paul Moran].

"Public 'treated as fools' on Chaffers", Contact, 12 March 1998 [commentary by Mary Varnham].
} 


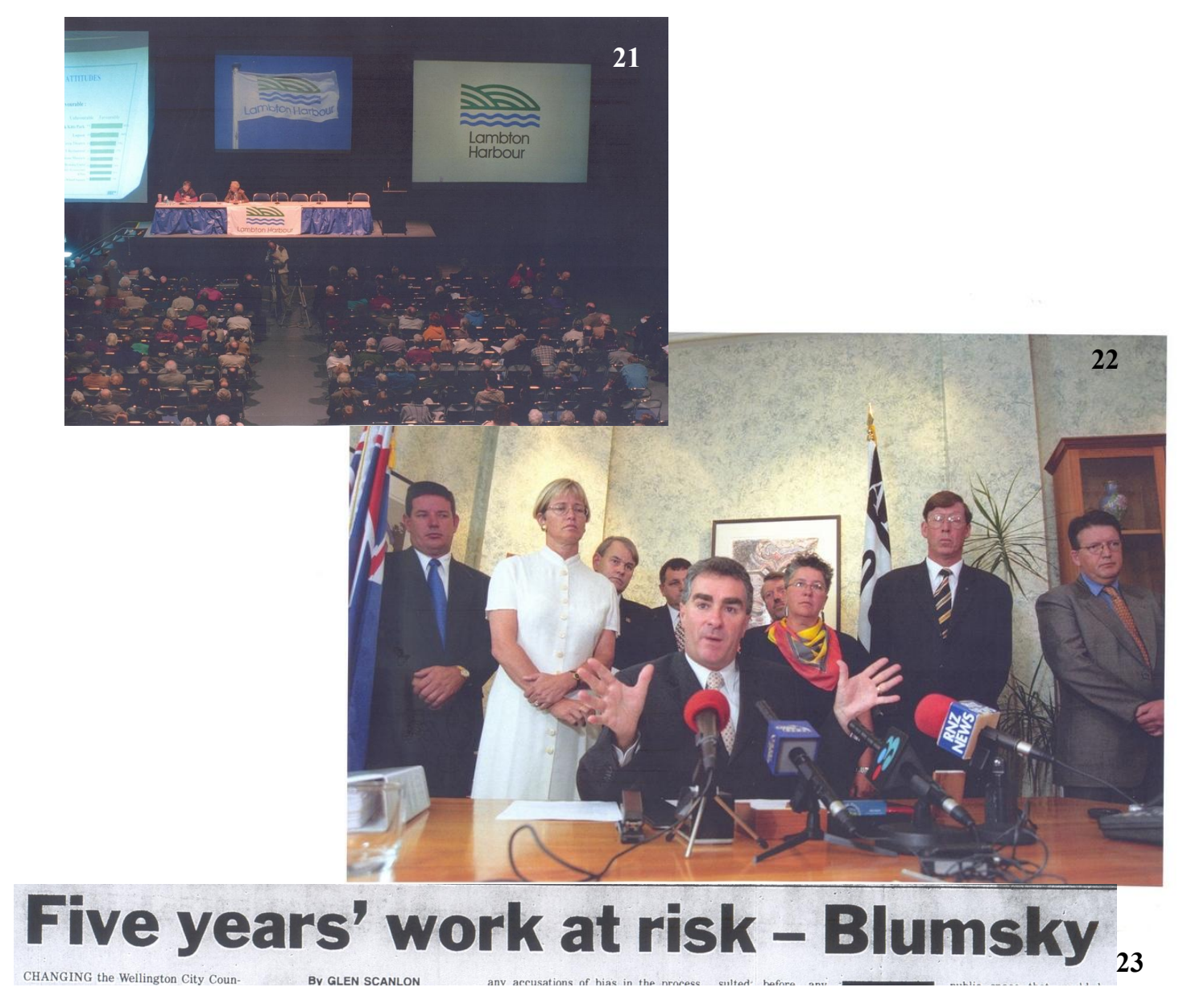

Yet in February of 1998, Council gave its approval for a row of multi-storey edifices to be erected around two sides of the Chaffers area, effectively ignoring the thrust of the 1996 petition that called for an open space without buildings. Wellingtonians set about challenging their Council over this move and won - or so it must have appeared at the time. In April of 2000, mass protests finally resulted in Council pulling the plug on Variation 17, one of its most controversial and unpopular plans for the waterfront ${ }^{9}$.

\footnotetext{
9 'Big city park at Chaffers a step closer', The Evening Post, 3 September 1997.

Chaffers Park - Make it Happen! newsletters, No. 3, 5 September, 1997, No. 6, 27 February 1998.

'War on the Waterfront', The Evening Post, 19 January 2000.

'Harbour plan gets a rough ride', The Dominion, 14 January 2000 [commentary by Leah Haines].

'Five years' work at risk - Blumsky', The Dominion, 29 January 2000.

'Wrestling on the waterfront', The Dominion, 15 February 2000.

'Sombre council pulls Variation 17 plug', The Evening Post, 14 April 2000.
} 


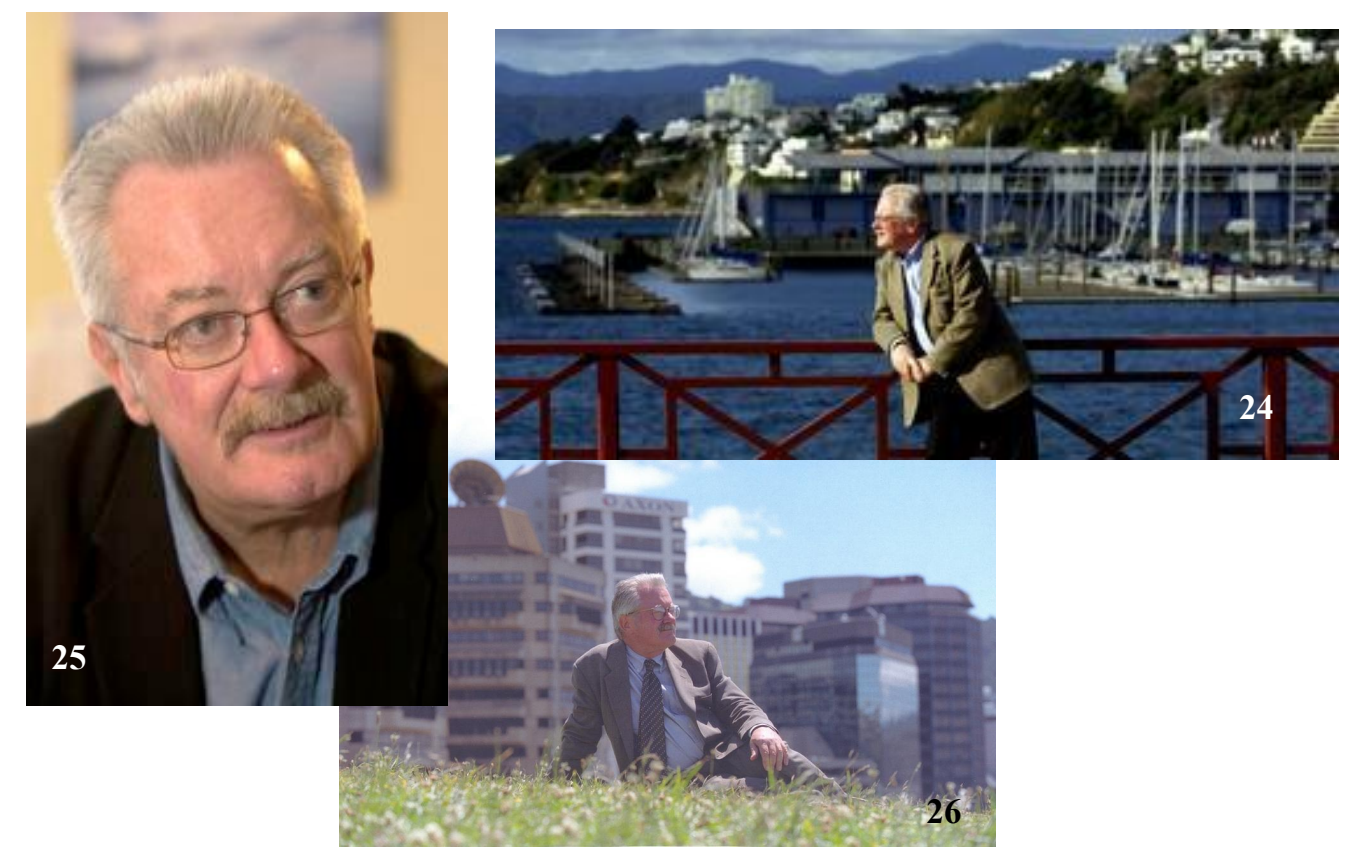

Lindsay Shelton, then Marketing Director for the New Zealand Film Commission, wasn't prepared to leave decisions concerning the harbour's redevelopment to Council alone. In September of 1995, he, along with Helen Glasgow and others, established Waterfront Watch a lobby group dedicated to making sure the public's views were not only heard but acted upon. Lindsay spoke of his fruitless attempts to establish a dialogue with Council. How, over his eight years as president of the group, he discovered that this Council was only willing to listen to its professional advisors - not the public. When it was announced in late 1999, that Variation 17 made provisions for more than 20 new buildings along the waterfront, including a 12 storey tower, Lindsay and his committee set about campaigning against these plans. This campaign climaxed when 2000 people attended a protest meeting, in February of 2000, arranged by Waterfront Watch in Town Hall, the outcome of which was the withdrawal of Variation 17 some two months later. In the same year, Waterfront Watch lodged an appeal in the Environmental Court to stop Lambton Harbour Management from shifting the historic St. John's Ambulance Building from the street onto the wharf, in an attempt to make way for new buildings. Waterfront Watch's success in blocking this move set a legal precedent that others would follow ${ }^{10}$.

10 'Harbour Protest', City Voice, 22 February 1996.

'The waterfront: a re-designed process', City Voice, 30 May 1996 [commentary by Marguerite Scaife].

'Hundreds rally against harbour plan', The Evening Post, 28 January 2000.

"Council waterfront plans 'take people by surprise", The Dominion, 13 January 2000 [commentary by

Lindsay Shelton].

'Waterfront protest packs town hall', The Dominion, 2 February 2000.

'Stop the wall', The Evening Post, 2 February 2000.

'Smokescreen on the waterfront', The Evening Post, 5 February 2000 [commentary by Stuart Niven].

'Another waterfront battle brews', The Evening Post, 4 September 2001.

'Ambulance building stays put - court', The Evening Post, 13 December 2001.

Wellington Civic Trust newsletters, July, 2001, October 2001, March 2002.

Waterfront Watch newsletters, No. 31, March/April 2000 through to No. 41, March 2002. 
HAVE YOUR SAY: WWL will be displaying building designs resulting from their competition from 4 to 21 October. The display will be at the New Zealand Academy of Fine Arts, Queens Wharf, from 4 9 October and then at the Waterfront Project Information Centre (Shed 6, Queens Wharf) for the remainder of the exhibition.

WHAT IS THE PROBLEM WITH NEW BUILDINGS: On the plan there are five new buildings proposed for Waitangi/Chaffers Park. We oppose such buildings because they: occupy public land that should be dedicated to public recreation; obstruct views of the harbour; create wind hazards and shading; demand vehicle access.

WE HAVE TO TRY TO MAKE A DIFFERENCE! Even if we cannot have a $100 \%$ park we can still influence the outcome in terms of the number of new buildings and their scale. Come to the meeting and bring your friends, remember this is our city and this will be our waterfront park.

IF YOU OBJECT TO THE WAY SRE FIND OUT MORE

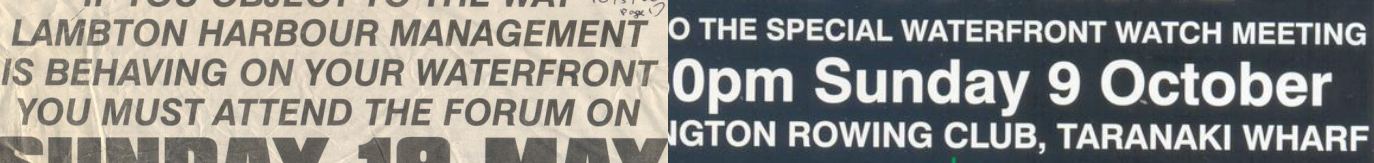
SUIDAY 19 MAY TELL. LAMBTON HARBOUR MANAGEMENT YOU DON'T WANT LARGE UGLY BUILDINGS COVERING THE OPEN SPACE ON YOUR WATERFRONT And, when you are there ask them And, when you are there... ask them:
Why they have gambleg 1818 million worth of debt on the chance of putting a casino on the water
. Why a company charged with runhing its projects AT NO COST TO COUNCLL is in debt at all? STARTS 9AM SUNDAY 19 MAY QUEENS WHARF RECREATION CENTRE REGISTER ON ARRIVAL AT THE DOOR. ANY TIME YOU CAN COME WIL BE TIME WELL SPENT EVERY VOICE COUNTS

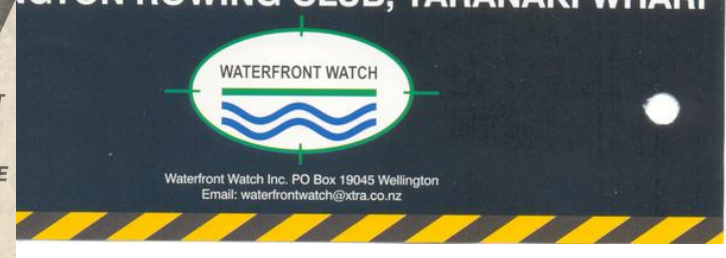

Shelton also found fault with Council's consultation practices, claiming that a mechanism didn't really exist for incorporating advice from the public coming out of these processes. Council just seemed to keep pushing through old concepts under new guises, always pressing for the addition of large buildings that threatened to block harbour views and public access. Shelton found the situation scandalous and was totally opposed to the idea of new buildings for the Chaffers area ${ }^{11}$.

11 'If you object to the way Lambton Harbour Management is behaving on your waterfront...', City Voice, 16 May 1996.

Doorne, Stephen M. (1998) 'Power, Participation and Perception: An Insider's Perspective on the

Politics of the Wellington Waterfront Redevelopment' in Current Issues in Tourism, Vol. 1, No. 2, 1998.

Doorne, Stephen (1998) The last resort: a study of tourism policy, power and participation on the Wellington waterfront : a thesis submitted to the Victoria University of Wellington in fulfilment of the requirements for the degree of Doctor of Philosophy in Tourism and Services Management.

Victoria University of Wellington.

'Up In Arms', The Evening Post Magazine, 29 January 2000.

'Oppose New Buildings on Waitangi/Chaffers Park', Waterfront Watch, leaflet, October 2005. 

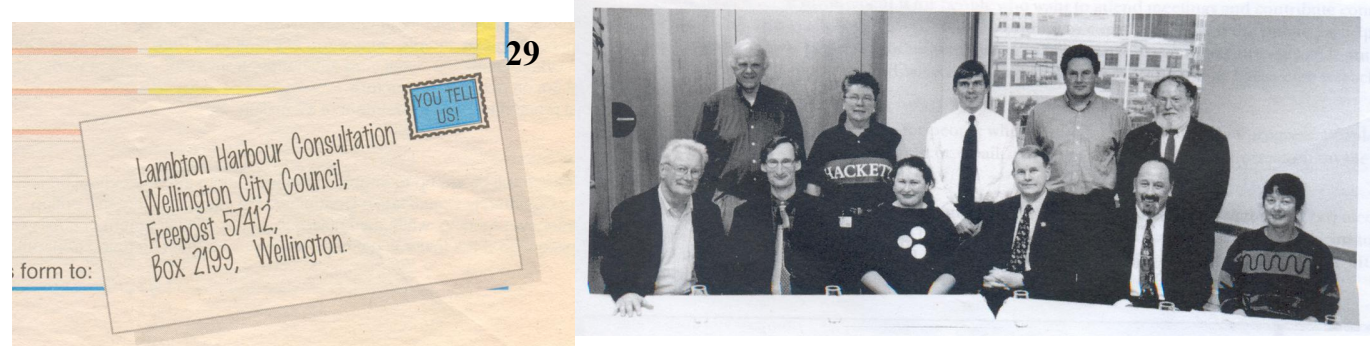

30

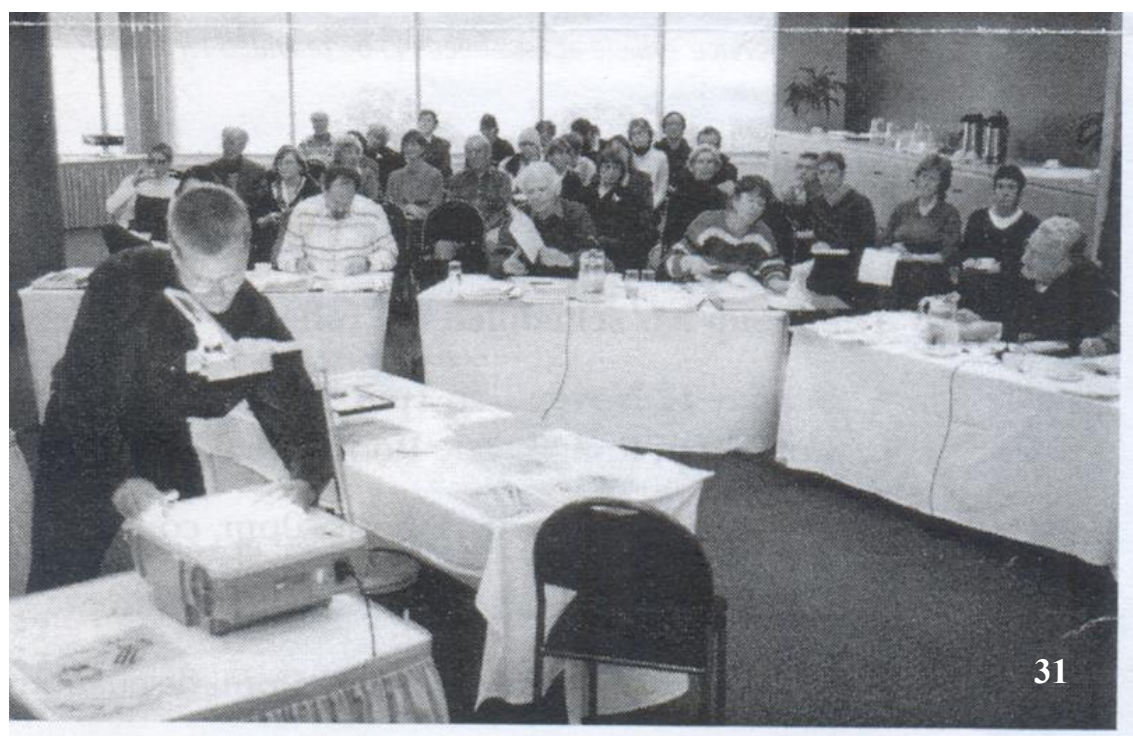

The time he had spent in workshops, and as part of the Waterfront Leadership Group, Shelton considered frustrating and counterproductive. 'You had five minutes to have your say, then that was it.' This negative view of consultation practices as being inadequate was supported by the Controller and Auditor-General, with claims that public confidence in the consultative process was undermined when there was a lack of feedback about final decisions, why they were taken, and what impact they might have in the future ${ }^{12}$.

\footnotetext{
12 “Applause greets 'no' to waterfront buildings", City Voice, 19 October 2000.

Brooks, Peter (1999) Public Consultation and the Waterfront: An account, based on the records of the Wellington Civic Trust, of the public consultations undertaken by the Wellington City Council in 1996-97 on the development of the waterfront, Wellington: The Wellington Civic, p.21.
} 


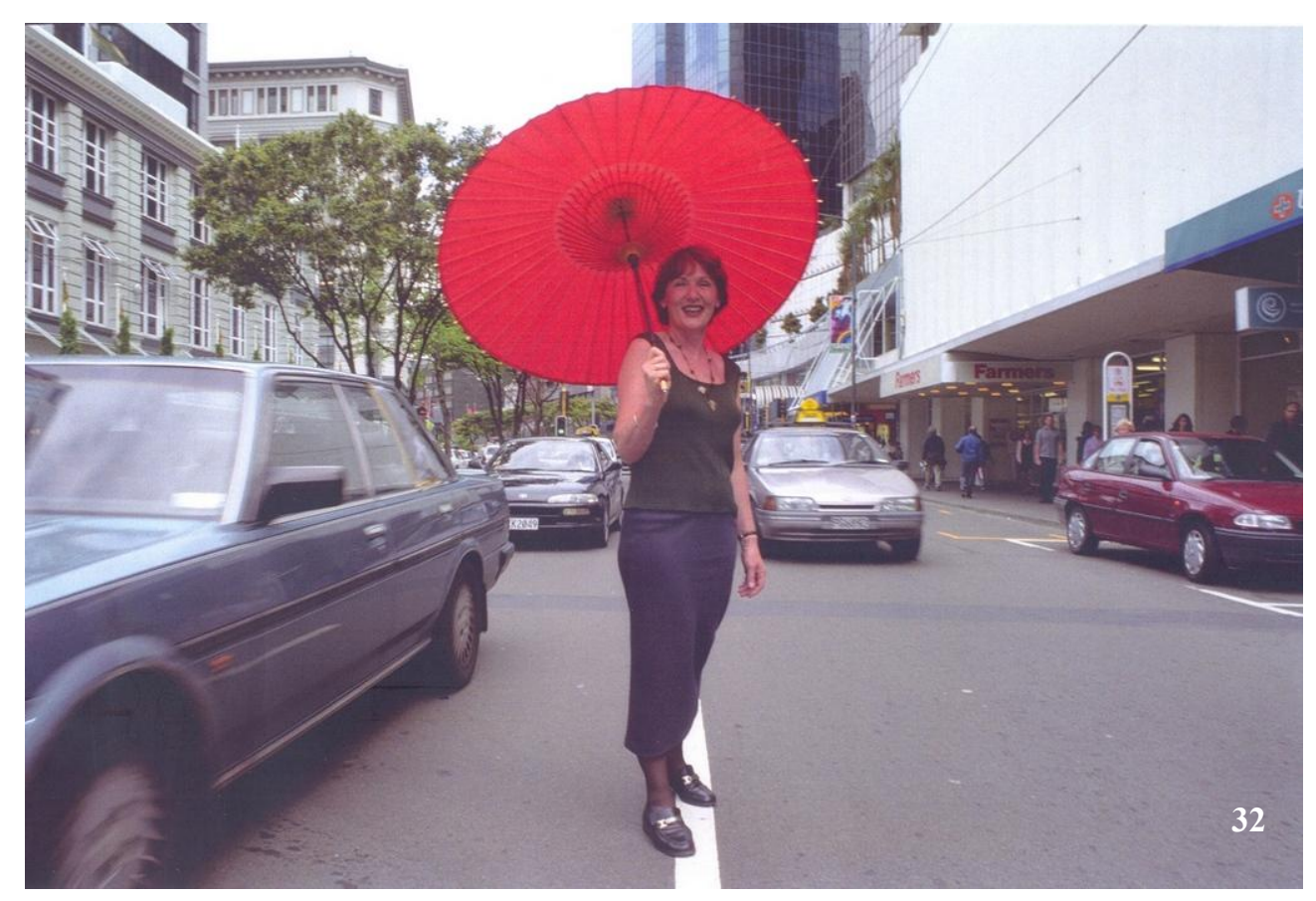

Another person committed to the $100 \%$ park idea was Mary Varnham, a freelance researcher and writer with Labour Party affiliations. Mary, like many other Wellingtonians, was opposed to Council's plans for the Chaffers site. She recalled setting up, in July of 1996, a small lobby group called 'Chaffers Park Make It Happen' in order to press for a green, open space. She also wanted to see what remained of the Corporation Yard Buildings saved because of their historic value and charm. 'I became enraged,' Mary said, 'when I found out that public land was going to be used for the most hideous looking development.' It was unthinkable considering Council had already conducted a survey, in July of 1997, which clearly indicated the majority preference for more parks and recreational areas along the waterfront. In it, $70 \%$ of respondents stated that only minimal residential, or commercial, development ought to be allowed. So with this in mind, she decided to get together a bunch of people and do something about $\mathrm{it}^{13}$.

\footnotetext{
13 'Fighting through the tack to get to the water', The Evening Post, 17 August 1995 [commentary by Mary Varnham].

'Lambton Harbour dream a nightmare', The Evening Post, 9 May 1996.

'Debate encouraged but let's get facts right', The Evening Post, 17 May 1996 [commentary by Malcolm Woods, Chairman Lambton Harbour Management].

'Chaffers must become a true city park', The Evening Post, 15 December 1996 [commentary by Mary Varnham].

Chaffer Park - Make it Happen! newsletters, August 1, 1997, 5 September 1997, February 20, 1998.
} 

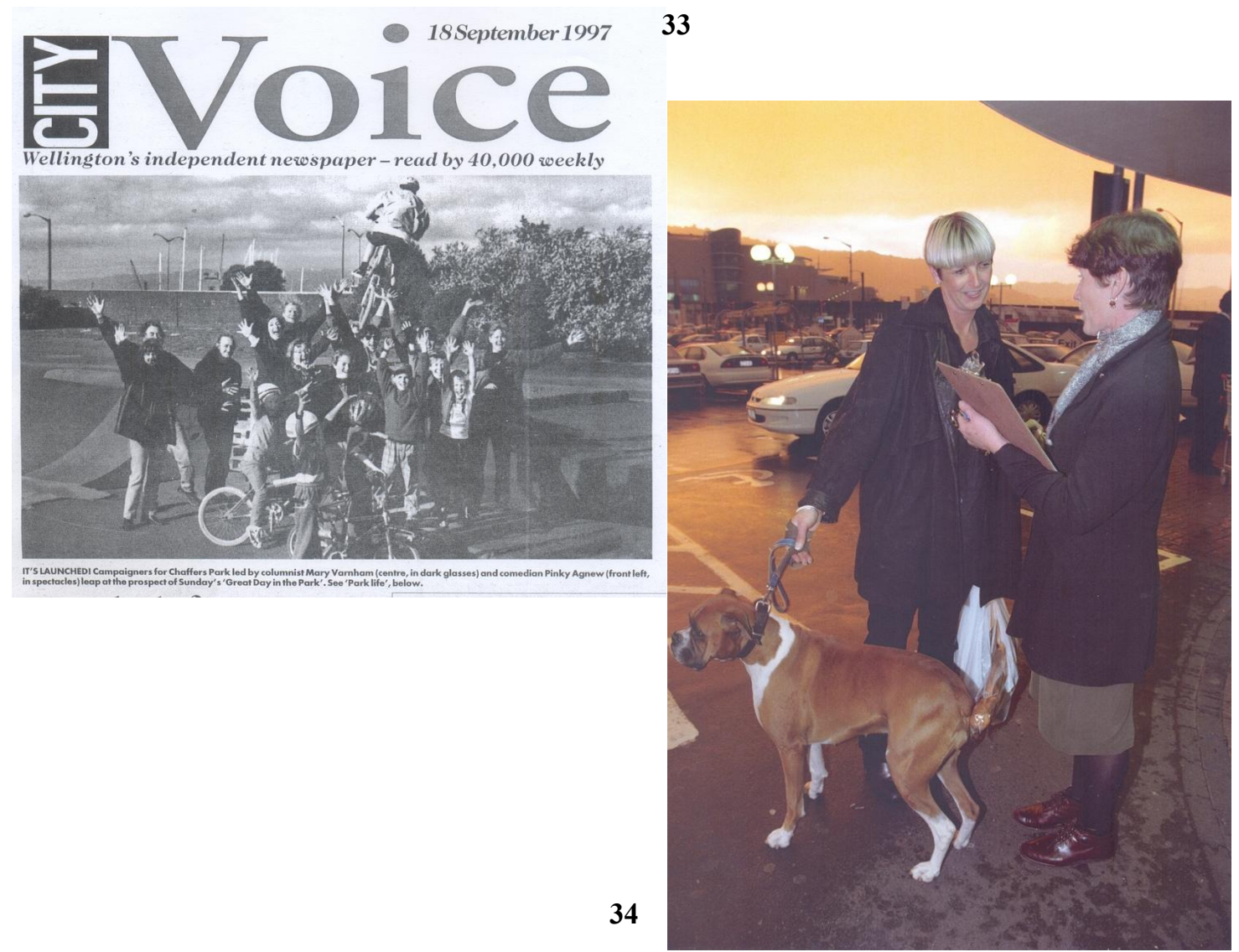

'We created a flyer called something like "Save Our Park". I remember going round to the New World Supermarket car park and putting it under car windscreens. Then we started advertising in the City Voice, a civic-minded newspaper. Within a few weeks $\$ 38,000$ had been raised for our campaign which was incredible support.' Mary also conducted a number of surveys to find out what people wanted for the park, something Wellington City Council never did at the time because it was so adamantly opposed to the idea ${ }^{14}$.

14 'Waterfront test for council', City Voice, 26 November 1998.

'Chaffers needs buildings', City Voice, 26 November 1998 [commentary by Julia Gatley of the Wellington Architectural Centre]. 


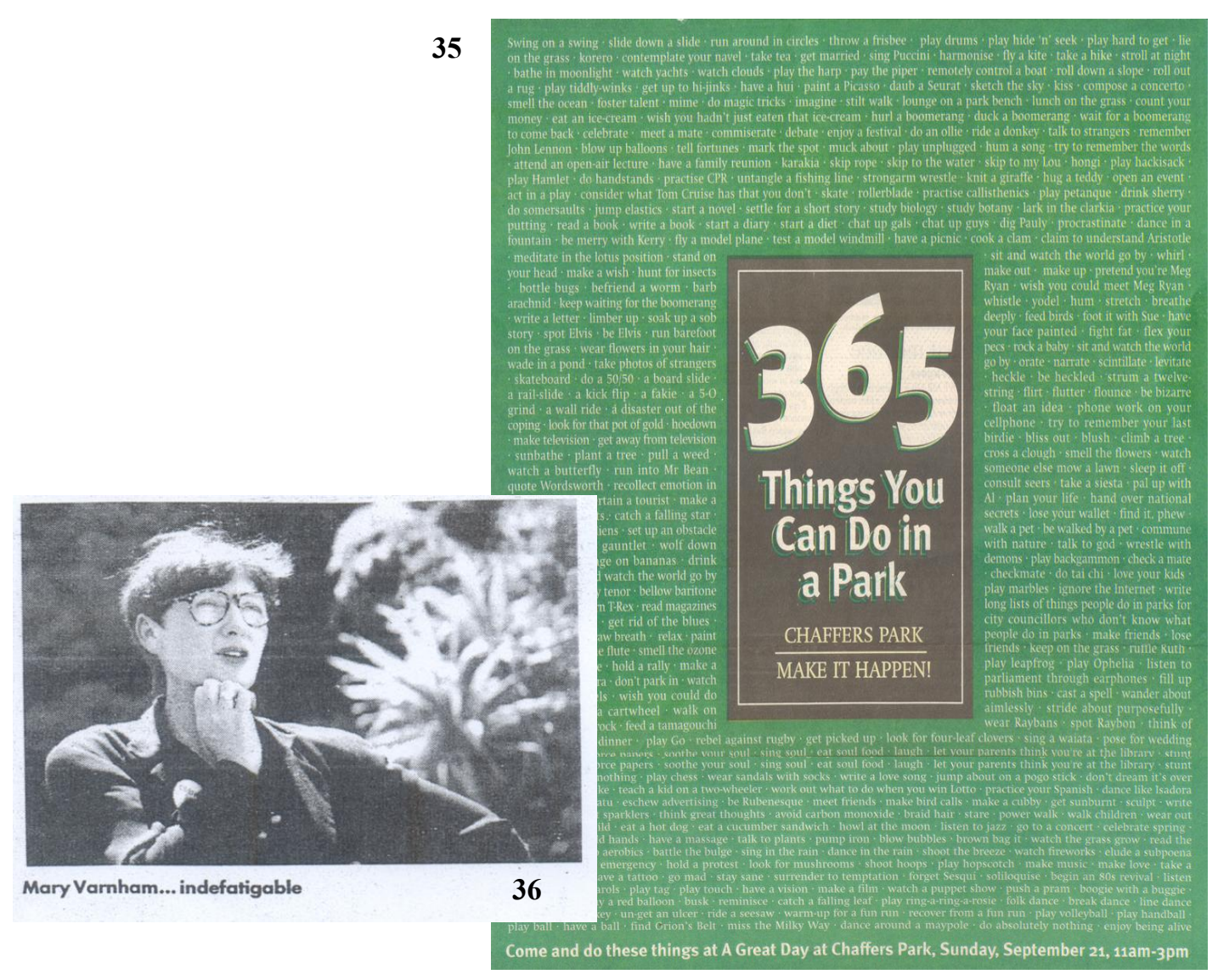

'Lots of people seemed to be thinking the same way as we were. They told me thank goodness someone is doing something about it. Their response encouraged us to go out and lobby Council, but we were hopelessly naïve in this regard. We just thought we would go there and say what the public wanted and Council would say yes, yes, yes! But their response astounded us; Councillors were overwhelmingly against the idea of a park. I remember one Councillor, Andy Foster, saying, "What do you do in a park?" In retaliation, we created a t-shirt listing "365 things to do in a park.", 15

15، Throwing herself into the cause', City Voice, 18 December 1997.

'Bleak park?', City Voice, 3 December 1998 [commentary by Mary Varnham]. 


\section{a great day at Chaiffers Park \\ Sunday, September 21, 11am - 3pm}

\section{The waterfront event of the year}

Bring your own activity. Come with family and friends. Have a picnic. Throw a frisbee. Paint a picture the world go by (bring your own chair)

Show your support for a park on the whole Chaffers site. Stop the city council privatising public waterfront land. ENTERTAINMENT • FOOD • STALLS

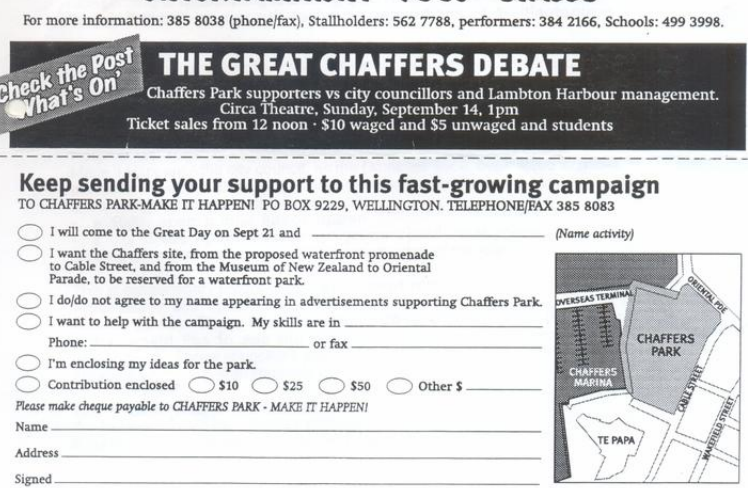
39
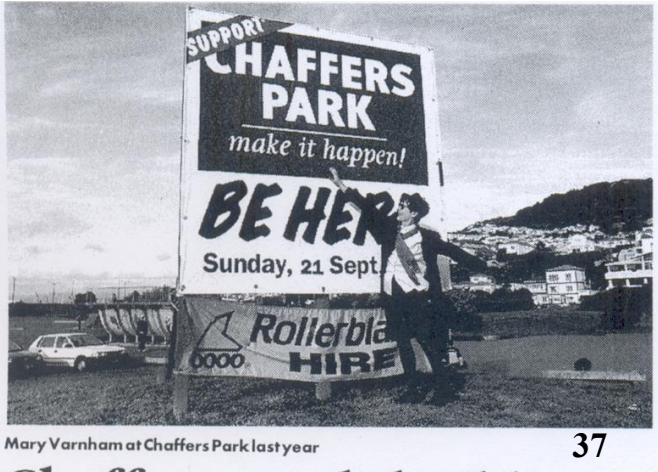

- $\quad 10$

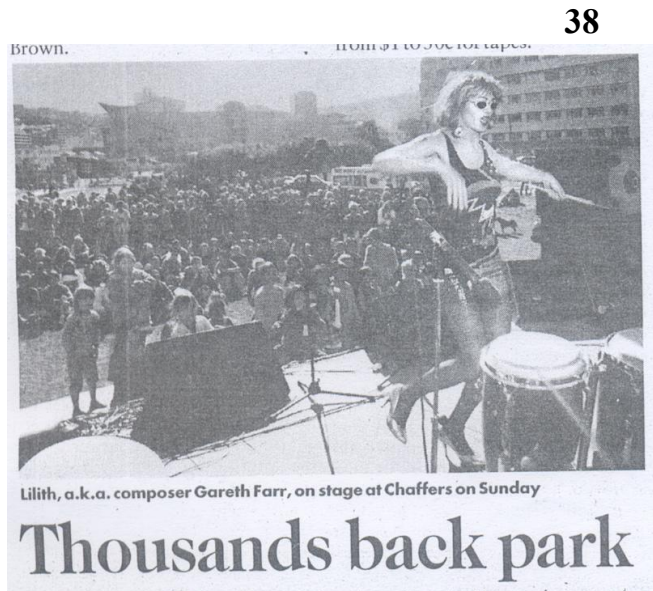

'But Council kept saying that nobody needed a park, that they wouldn't go there because there was Frank Kitts Park already. The only thing to do, we figured, was get people using the space by creating a special event. So we organised a party and called it "A Great Day at Chaffers Park." We had music and stalls and about 5,000 people attended, which was pretty good given the weather wasn't so good that day.' Mary's point was straightforward: 'The land is owned by the people of Wellington not the mayor - and he should let them decide what happens to it. ${ }^{16}$

16 'Campaign for bigger Chaffers Park', City Voice, 24 July 1997.

'Big city park at Chaffers a step closer', The Evening Post, 3 September 1997.

'Park Life', City Voice, 18 September 1997.

'Thousands back park', City Voice, 25 September 1997.

Chaffer's Park Campaign press releases and newsletters, No. 4, 16 October 1997. 


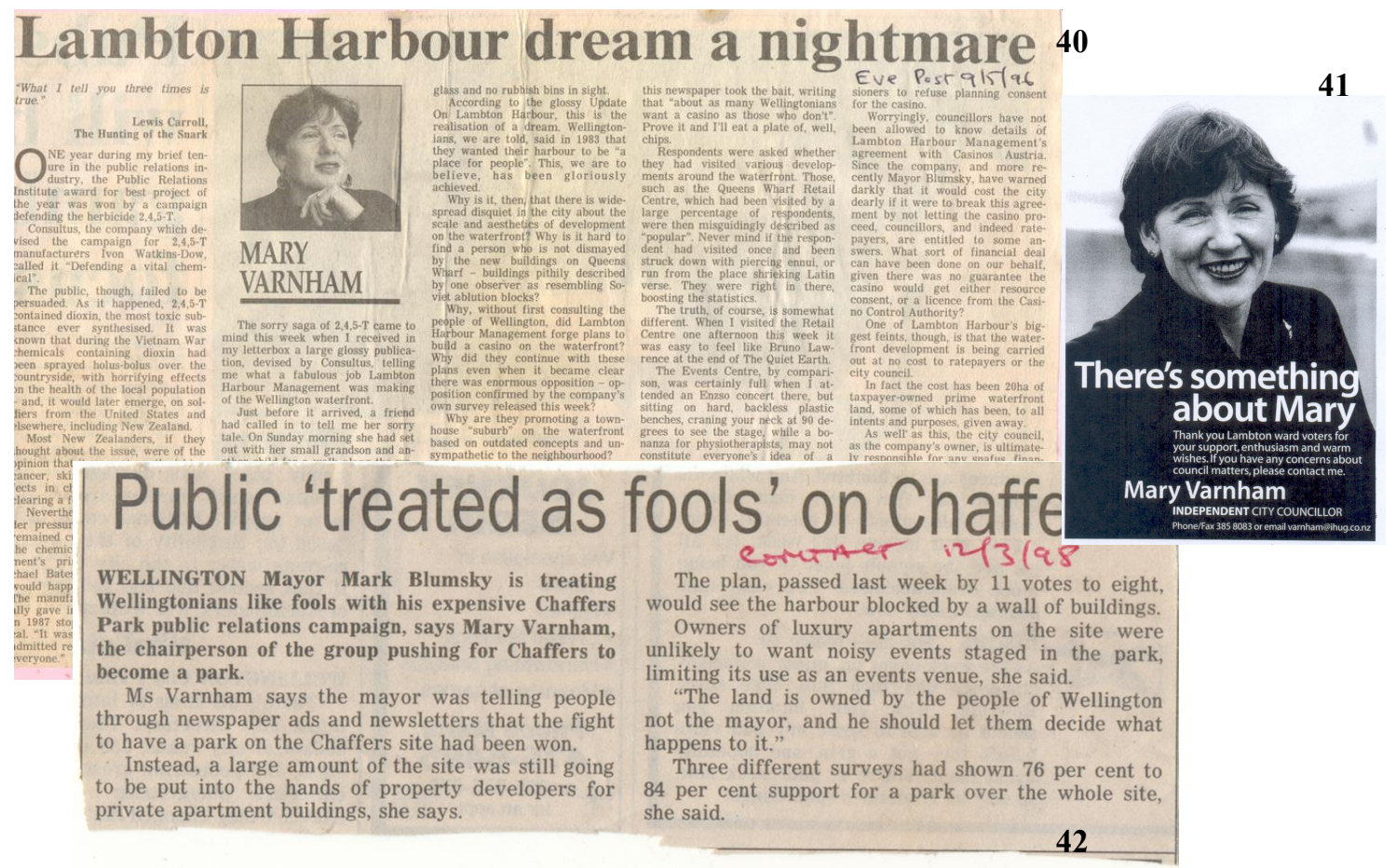

By 1998, things were getting nowhere so Mary decided to run for a seat on Council, and to her delight she got elected. 'I thought this would be the way to bring about change, from the inside.' But from the outset, forces in Council were aligned against her and the left/public interest sector she represented as Councillor for Wellington's Lambton Ward. Mary was on the outside which effectively made it impossible for her to get onto any committees dealing with the waterfront. 'Every effort was made to ensure that I didn't sit on any bodies that had decision-making powers in that area.' The whole experience was very distressing. Mary recalled situations where citizens would come along to Council meetings and make submissions, only to have Councillors put them down and rubbish their ideas. 'I was really stunned,' she said, 'by their attitude toward the public. Instead of drawing on the talents of these people, they just saw them as getting in the way of what Council really wanted to do. Council treated the public like their enemy, as something to be defeated rather than valued as a resource.' It was a far cry from her experience of New York City where Mary witnessed what she considered fairer and more effective engagement practices between local Councils and the public they represented ${ }^{17}$.

\footnotetext{
17 'Varnham in election', The Evening Post, 26 August 1998.

"Candidates claim 'lies' over Chaffers Park", City Voice, 24 September 1998.

'Constitutional issues in Variation 17 dispute', The Evening Post, 28 January 2000 [commentary by Mary Varnham].

'Variation 17 - It's a violation, not a variation', Chaffers Park - Make it Happen!, 7 February 2000.

'Blumsky's Folly', Chaffers Park - Make it Happen! Fax to members dated 12 October 2000.

'Varnham throws hat in mayoral ring', The Evening Post, 20 August 2001.

'Varnham seeks waterfront job', The Dominion, 27 February 2002.
} 


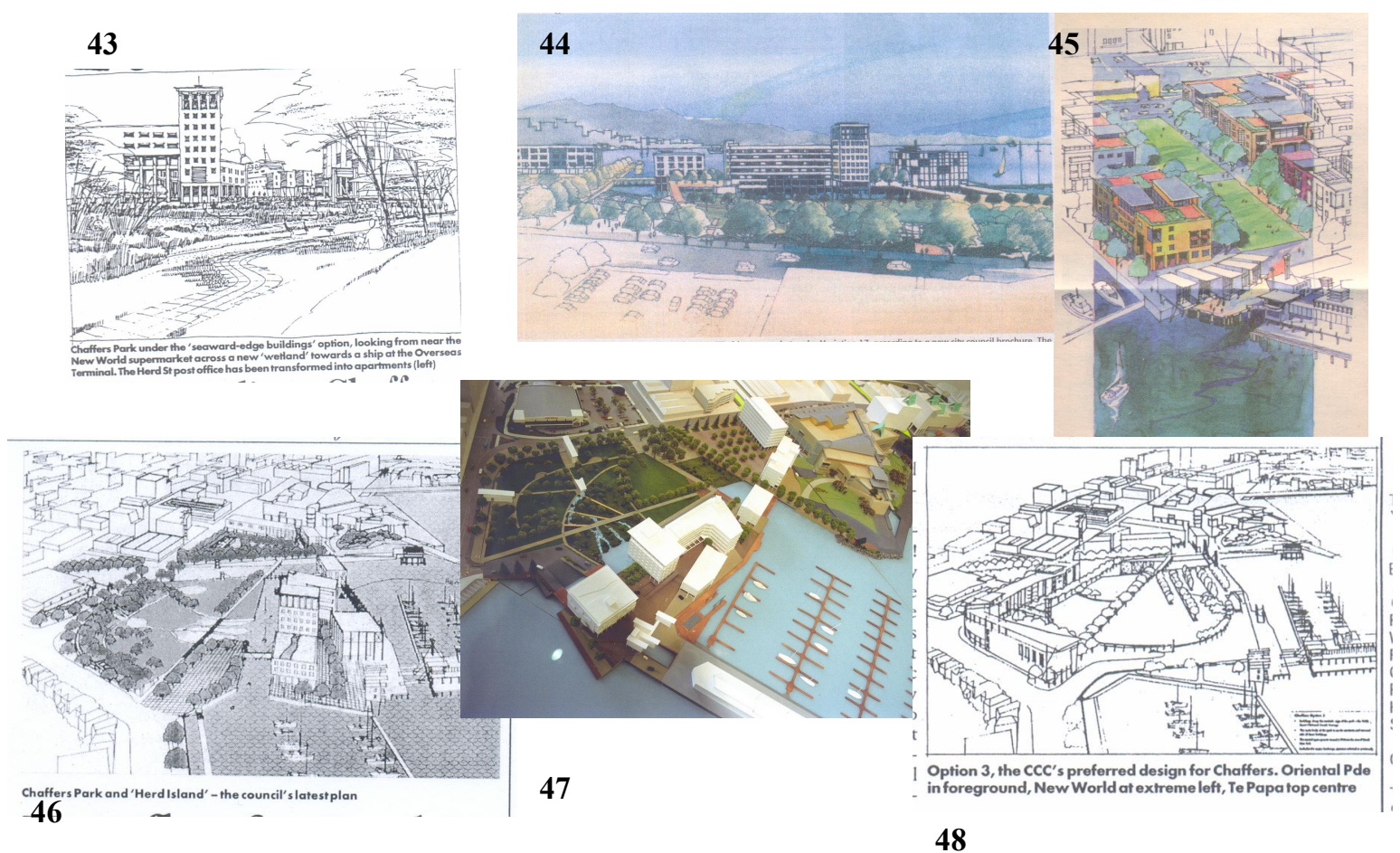

During the moratorium on waterfront redevelopment, Council worked on new concepts for the area. As part of this process, it enrolled a team of outside consultants composed of urban designers, architects and landscape architects to assist in coming up with new visions. A design process, conducted in the late 1990s, developed a number of proposals for a master plan. Various options were tested to find the optimum amount of buildings that the Chaffers site could accommodate. Decisions about buildings - how big, how many and where - were based on the quality of open space different types of configurations could provide. One particular scheme which provisioned for buildings along the seaward edge of the park caused an uproar with newspaper headlines reading 'Stop the Wall'. Wellingtonians came out in force to protest this plan, sending Council back to the drawing board yet again. In the general melee, it was easy to miss the small announcement, in December 2001, notifying the public that a competition was about to be held to select a design for Chaffers Park ${ }^{18}$.

\footnotetext{
18 'Getting Lambton Harbour back on track', Wellington City Council, Special Lambton Harbour consultation edition, July 1997.

'Harbour plan gets a rough ride', The Dominion, 14 January 2000.

'A better public space', The Dominion, 19 January 2000 [commentary by Mark Blumsky].

'War on the Waterfront: Latest scheme reopens divisions: The council claims the development will draw people to the waterfront. Opponents say Wellingtonians don't want it', The Evening Post, 19 January 2000.

'Hundreds rally against harbour plan: MPs join the call against proposal', The Evening Post, 28 January 2000.

'Stop the Wall', The Evening Post, 2 February 2000.

'Waterfront battle close to the edge', The Dominion, 2 February 2000.

'Chaffers Park design contest', The Dominion, 13 December 2001.
} 


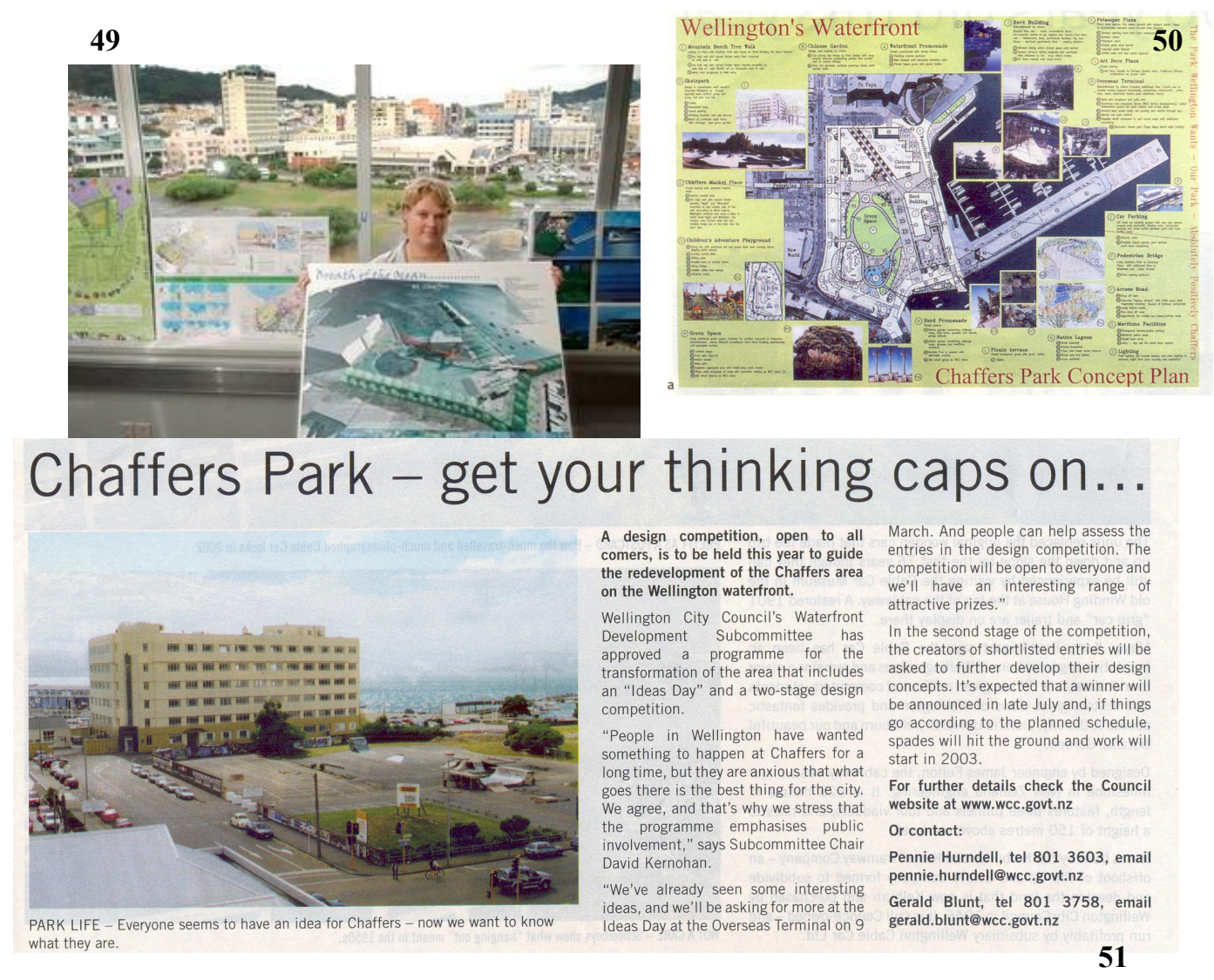

The structure of this competition would be two-staged, much like the Harbour City Competition of 1983, but with a significant difference. Whereas in the earlier competition only architects had been allowed to participate in its second stage, this time anyone with a good idea could go on to the finals so long as they had the backing of qualified professionals. In theory, this meant that a member of the public could win. At the time, Mary Varnham thought this competition was a step in the right direction. She even put together a scheme of her own in collaboration with Weta Workshop, and Alan Titchener, which the public selected as its favourite ${ }^{19}$. Council originally planned to chose only four finalists from amongst 17 drawn from a field of 129 eligible entrants ${ }^{20}$. However a fifth entry, that of Rachel Hughes, was selected to take part in Stage 2 possibly because her design was the only one to fully embrace the $100 \%$ park idea that lobby groups and the public demanded ${ }^{21}$.

19 'Oscar winner fails to make park design cut', The Evening Post, 25 May 2002.

20 'Possible Chaffers designs to be revealed', Wellington City Council website, 16 May 2002.

'International line-up for next Chaffers design stage', Wellington City Council website, 21 May 2002.

'Chaffers designs open to public feedback', Wellington City Council website, 4 October 2002.

21 'Chaffers' future inspires designers', The Evening Post, 19 April 2000.

'Design brief for Chaffers Park', The Evening Post, 11 December 2001.

'Chronology of waterfront developments', The Dominion, 2 ${ }^{\text {nd }}$ Ed., 21 April 2001.

'Park design plans at a glance', The Dominion Post, 9 October 2002. 


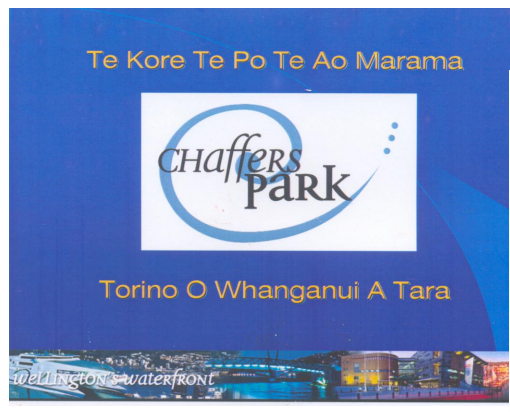

52
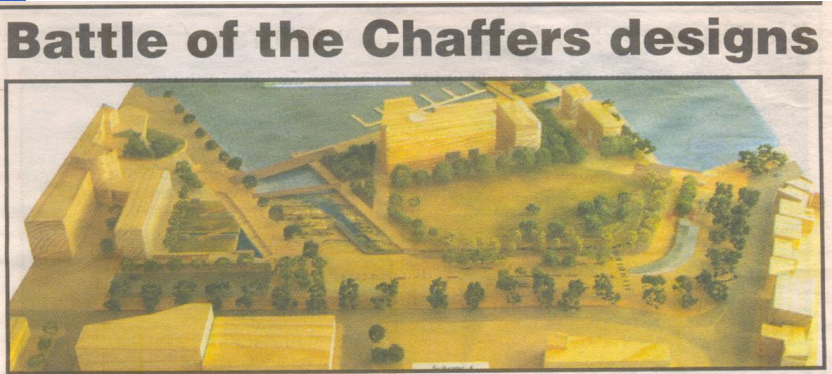

The winning Scheme A (above) is designed by Megan Wraight Landscape Architects, Athfield Architects, Stantiall's Studio and department of public works New South Wales. Waterfront development subcommittee member Ray Ahipene-Mercer says he fully backs this design, because "culturally, environmentally and recreationally, it was far superior". However, council has committed to reducing the height of the buildings incorporated in the plan, reviewing the wetlands part of the design, the connections for mana whenua and the area allocated for the Chinese garden. Scheme D (below) - designed by Rachel Hughes, Beca Carter, Novak and Middleton Architects and Earthwork Landscape Architects - includes a flying fox and a large killer whale sculpture. The design has been criticised for being too detailed, not allowing it to be changed or adapted over time.

53

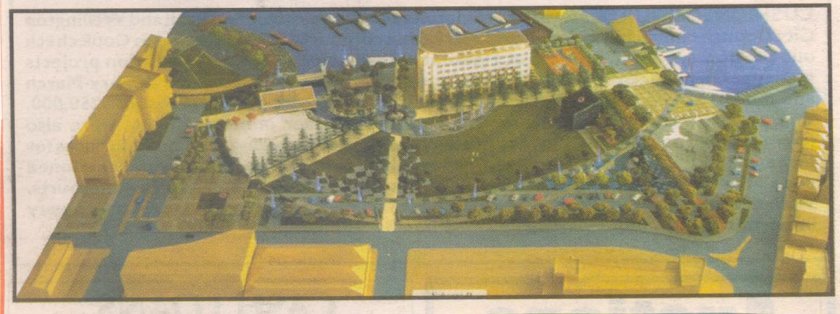

Out of these five finalists chosen, two would end up battling it out for the prize: Scheme A, shown at the top, and Scheme D, below. A meeting was held, in October 2002, to thrash out the merits and failings of all finalists at which Scheme A was praised for being culturally, environmentally and recreationally superior. Scheme D, on the other hand, was criticized for being too detailed and not allowing for change, or adaptation, over time. Nonetheless, Scheme D had been selected as the people's choice, being considered by many public space advocates as a triumph because it called for a $100 \%$ open, green space with no new buildings. Its design was also applauded by lobby groups who were quick to associate themselves with the scheme. However, the Waterfront Development Subcommittee which was judging the competition favoured Scheme A, as did design experts on its Technical Advisory Group $^{22}$.

22 'People don't want Chaffers buildings, watchdog warns', The Evening Post, $3^{\text {rd }}$ Ed., 30 January 2002. Johns, Ralph (2002) 'Wellington waterfront so far so good' in Landscape New Zealand, Jan/Feb., pp.12-15. 'Crunch time for Chaffers Park site', The Dominion Post, 25 November 2002.

'Experts' plan gets Chaffers nod', The Dominion Post, 26 November 2002.

'Waterfront Watch to meet over Chaffers decision', The Dominion Post, 27 November 2002.

'Controversy over capital's new urban park', The National Business Review, 29 November 2002.

Green, Suzanne (2002) 'Chaffers on show' in Landscape New Zealand, Nov/Dec., pp.46-49.

'Battle of the Chaffers designs', Cook Straight Times, 2 December 2002. 


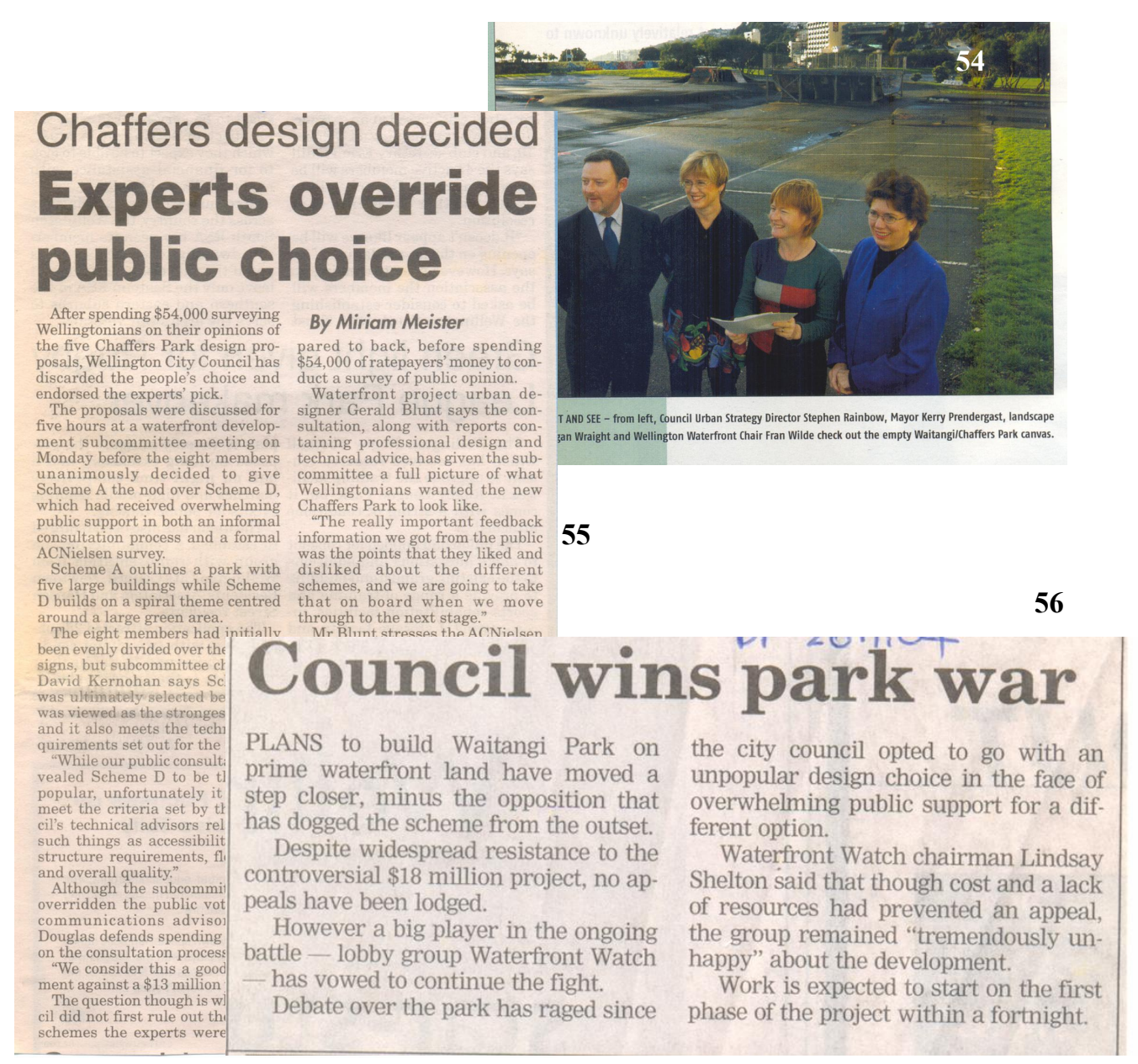

When Scheme A was finally selected to win the competition it caused a few raised eyebrows, but Council could show that a rigid process had been followed to the letter, thereby silencing critics. Nonetheless, the decision rankled. Five models had been displayed for a month, allowing the public to view the designs and select their favourite. Preference was shown by filling in, and depositing, a form supplied by Council which it then tallied up. Of the 3,530 visitors attending the exhibition, 1,020 filled out a form. Numbers indicated that Scheme D was by far the most popular design but Council chose to ignore this finding, as well as results from an ACNielson survey it commissioned which supported this view, opting instead for Scheme $\mathrm{A}^{23}$. Incensed, lobby groups called foul, saying the vote was clear and should be abided by. Council countered by saying that it had never been a voting situation - only a call for comments. Besides, lobby groups were alleged to have attempted to sway the competition outcome, at both stages, by tampering with the forms ${ }^{24}$.

23 ACNielson, Chaffers Design Competition, November 2002, p.5.

24 'Blind eye to public in Chafers designs', The Evening Post, 21 May 2002.

'Chaffers design decided: Experts override public choice', Cook Straight Times, 2 December 2002.

'Council wins park war', The Dominion Post, 28 January 2004. 


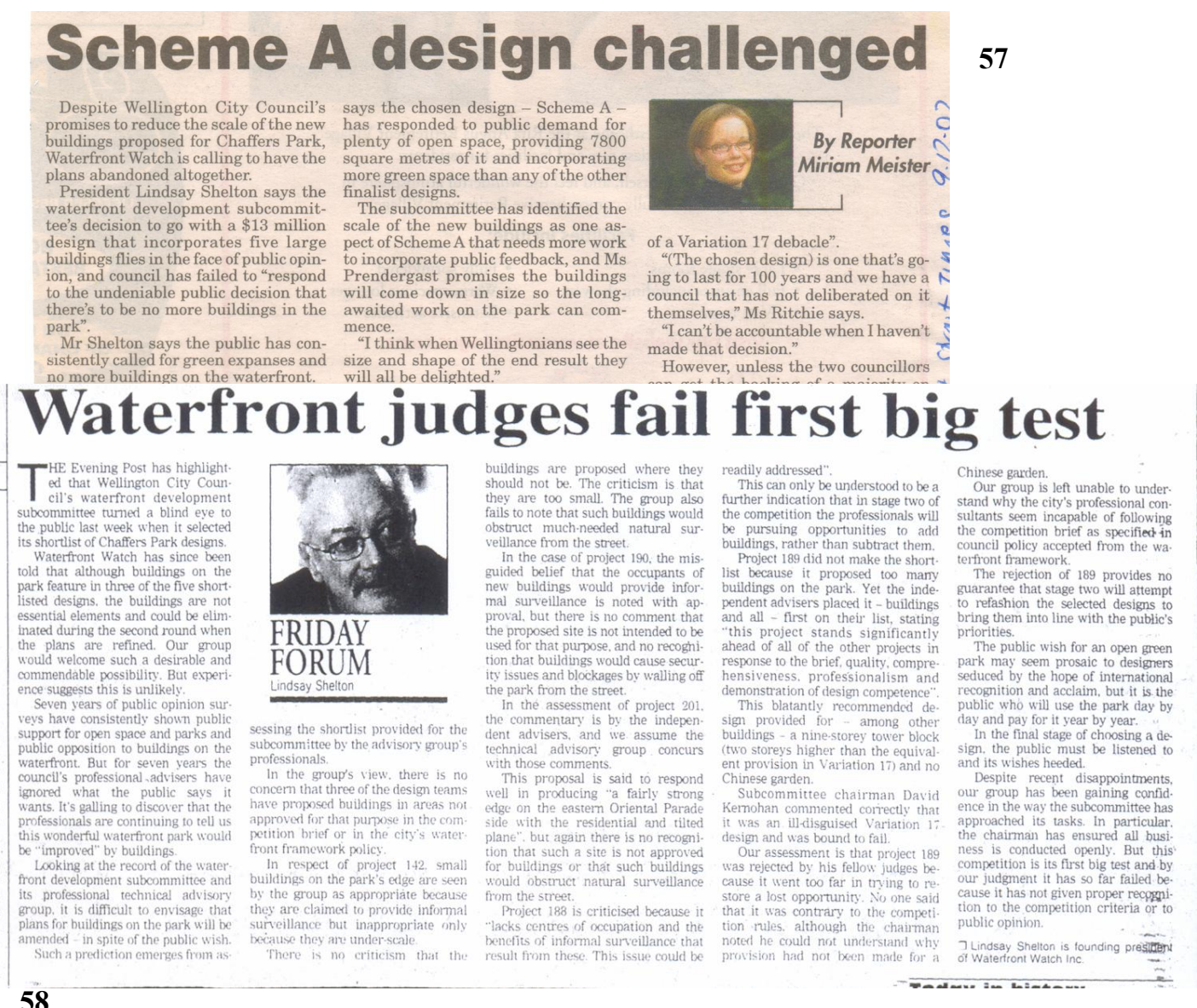

In raising this issue of vote tampering with Lindsay Shelton his only comment was, 'would that we were so organized.' He certainly never instructed any of his Waterfront Watch members to do so, but it did show a certain lack of organization on Council's part if forms could be spirited away like that and supposedly duplicated. Mary Varnham laughed outright at the idea, saying that her busy team had no time to even attend the exhibition, let alone vote. So what was going on? Mary believed the competition was a jack-up from start to finish. 'Scheme D never had a chance of winning because it was always going to be Scheme A.' Shelton was equally annoyed, calling the final choice a failure. However, the decision stood ${ }^{25}$.

25 'Waterfront judges fail first big test', The Evening Post, 31 May 2002.

'Park backers deny dirty tricks', The Dominion Post, 21 November 2002.

'Scheme A design challenged', Cook Straight Times, 9 December 2002. 


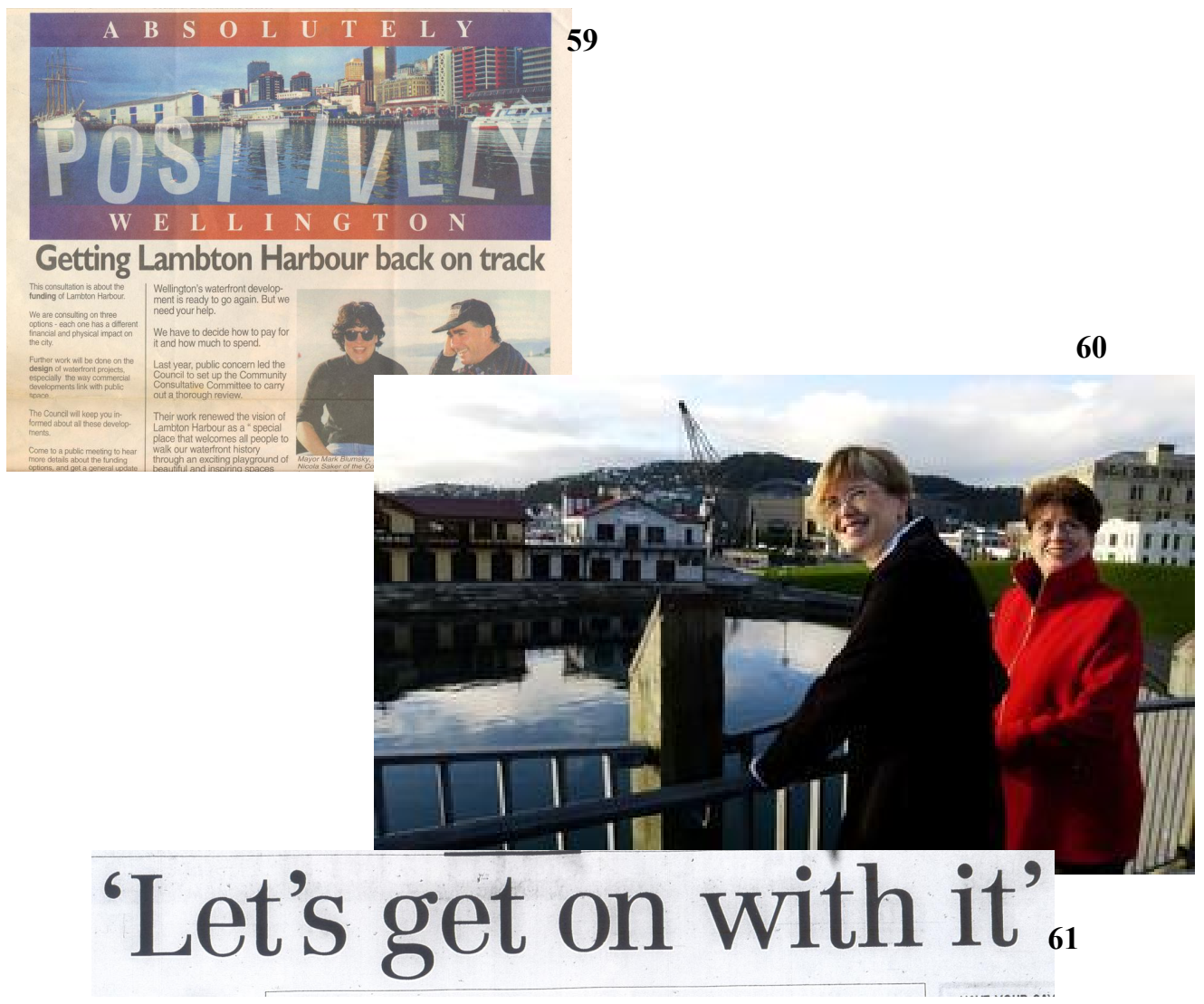

Meanwhile, the newly elected Mayor, Kerry Prendergast, claimed enough consultation had been done, that it was time to get on with it. Someone had to make decisions and that someone was Council, as official representative of the public, not disaffected lobby groups that represented only a handful of Wellingtonians. Truth to tell, not everyone supported Shelton's stance because it was viewed as unnecessarily obstructionist at times. Many preferred Council's progressive attitude with its promise of economic and cultural growth for the city. Others, however, were of the belief that Council's plans outweighed community welfare, a perception that fuelled deepening suspicion. In looking back over media coverage at the time, it becomes apparent that an oppositional mode of interaction was in the process of becoming entrenched, and that a mood of distrust had begun to pervade relations between Council, lobby groups, and the public. But Council's sunny newsletters rarely alluded to any problem which only showed how blind texts could be $\mathrm{b}^{26}$.

\footnotetext{
26 'What people want and why they don't get it', The Dominion Post, 20 January 2003 [commentary by Lindsay Shelton].

'Waterfront decisions', The Dominion Post, 20 February 2003 [commentary by David Kernohan].

'Park building plan faces fight', The Dominion Post, 5 May 2003.

'Chaffers park area approved', The Dominion Post, 13 May 2003.

'Cynicism not too surprising', The Dominion Post, 11 June 2003.

'Who can we trust?' The Dominion Post, 19 July 2003.

'Let's get on with it', The Dominion Post, 23 July 2003, p.B5.

'Waitangi Park Site Blessing', Wellington City Council website, news release, 2004.

Wellington City Council, On the Waterfront, first issue, May 2004.
} 


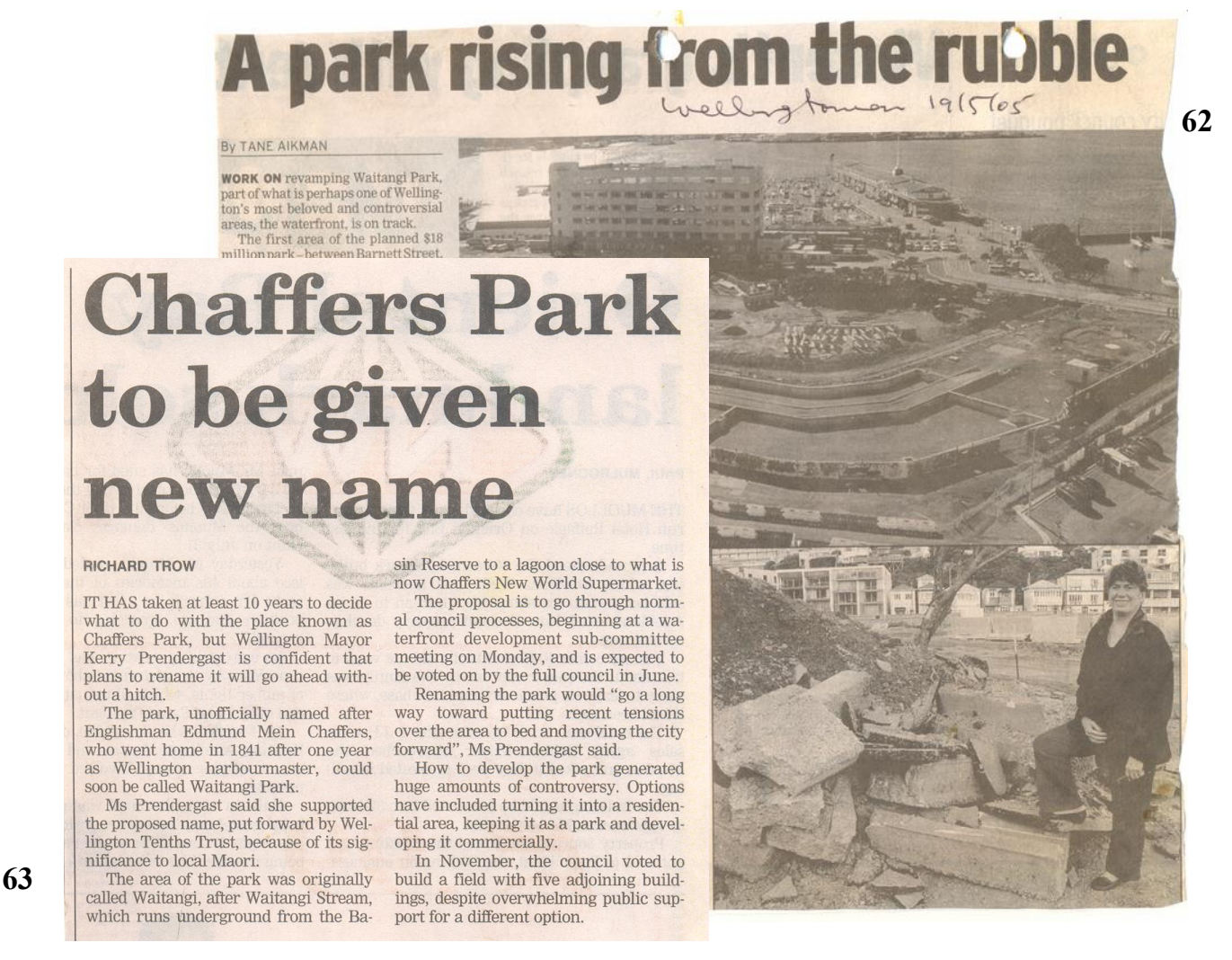

As part of a re-branding exercise, Chaffers Park would be renamed Waitangi Park in recognition of the Waitangi Stream that once flowed beneath the site. It was now being brought back to the surface in a design scheme that some critics unkindly referred to as an open sewer and mosquito breeding swamp. Mary Varnham thought this name change was a convenient way of burying the debate, and any reference to its instigators. The least Council could have done was acknowledge the public's efforts, as well as those of lobby groups, in getting a park on the site rather than some housing estate. But Council now seemed intent on claiming sole authorship of the project which was an ironic turn of events, given its long-standing rejection of the park idea. Nor were members of lobby groups invited to the sod-turning ceremony inaugurating the beginning of the build, likely because Council wanted to bury the fact that it had been forced to bow to public pressure $^{27}$.

27 'Use of stormwater in park', The Dominion, 2 February 2000.

'Chaffers Park to be given a new name', The Dominion Post, 11 April 2003.

'Shore to rise', The Dominion Post, 19 July 2003.

'Waterfront warriors, The Dominion Post, 22 July 2003.

'Taking a stroll into the future', The Dominion Post, 25 July 2003.

'Who can you trust with the waterfront?', The Dominion Post, 26 July 2003.

'Farewell for Chaffers Park', The Dominion Post, 23 October 2003.

'Group attacks park sewage plans', The Dominion Post, $2^{\text {nd }}$ Ed., 17 November 2003.

'A park rising from the rubble', The Wellingtonian, 19 May 2005. 


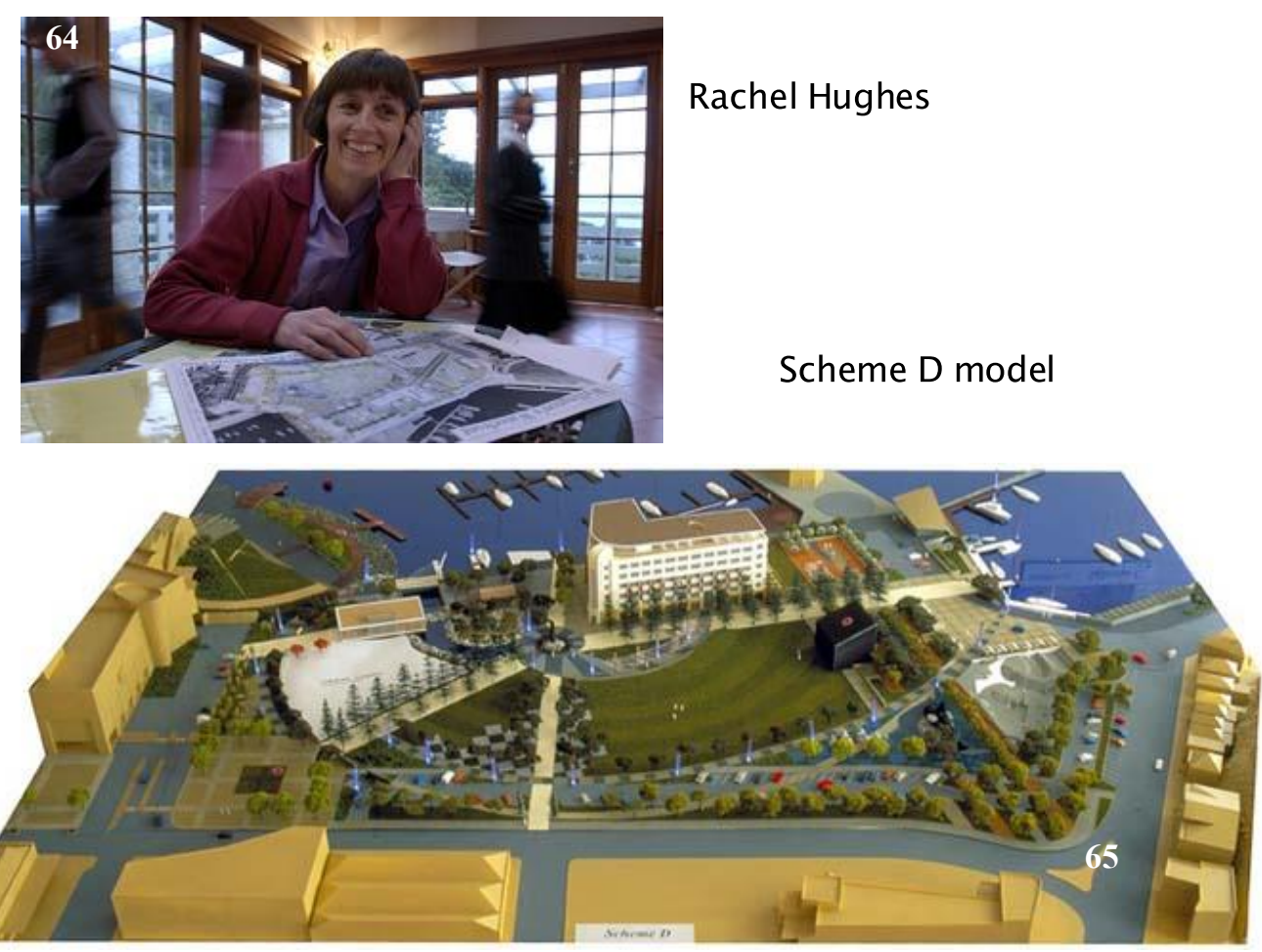

I interviewed the designers of Scheme D, the runner up in the competition, talking first to the team leader Rachel Hughes, an engineer by profession. I asked her to describe the vision she had for this unrealised park. 'It was quite simple really,' she replied, 'the park was meant to be a destination with multiple functions for people to enjoy.' It was designed to include a balance of open spaces, plants and facilities, providing a visually aesthetic and welcoming experience. Just a place that gave you a good feeling and that you really wanted to be in.' The scheme's detailed model showed a distinctive blue torino, a Maori term, at its centre symbolizing the eons of time. There was a memorial to Ancestors in the form of an upturned waka positioned on an island at the centre of this swirling form. This proposal allowed for all the normal park facilities, such as a children's playground, a skate park, a market square, pétanque court, picnic areas, and a tea pavilion with Chinese Garden. There were places in which to sit, walk, bike ride, stage festivals and ceremonial occasions. Artworks, representing Maori, British and Chinese culture, had also been provisioned for throughout the grounds, making for a variety of spatial experiences ${ }^{28}$.

28 'Garden in waiting', City Voice, 24 February 2000.

'Part-timer has big plans for city park', The Dominion, 23 May 2002.

'Park design favourite chosen', The Dominion Post, 16 October 2002. 


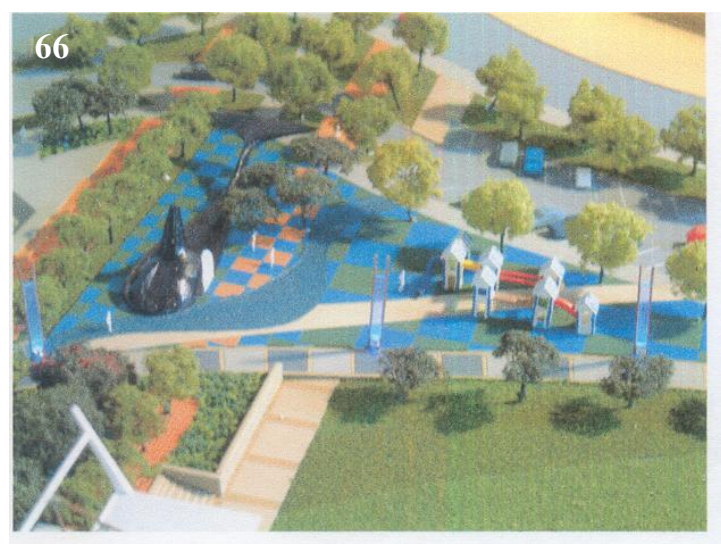

\section{Scheme D}

Playground facility with

Orca and flying fox

\section{Scheme A \\ Children's playground \\ Waitangi Park}

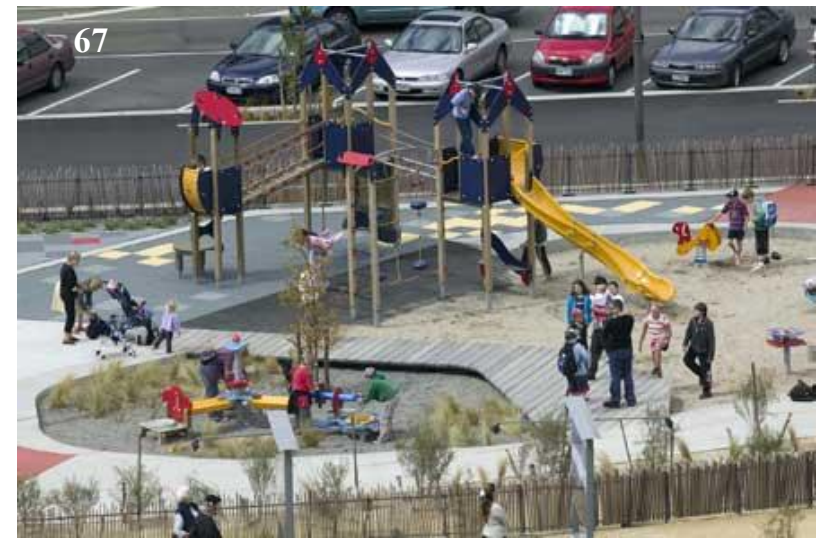

Rachel recalled the moment she found out her design had been selected to go on to Stage 2 of the competition. 'It was an amazing experience, although I can't remember all the details of that meeting. But to be sitting in that room having them make the decision in front of you. Ours was number 148, or something like that. First the scheme was "in" and then it was "out", and then it was "in" again, and was "out". Finally we were "in" and I just couldn't believe that I had made it. At that point I thought it was a genuine competition. I felt this was amazing, I just couldn't believe it. I was really, really pleased. ${ }^{29}$ Upon hearing the good news, she set about assembling a team of professionals which included not only architects Novak \& Middleton, landscape architects Earthwork, and engineers Beca, but also artists Robyn Kahukiwa, Chris Booth, Noeline Walker, skatepark designer Campbell Johnson, playground specialists Galloway International, and model maker Florian Franzmayer.

29 'Park design is a winner', The Dominion Post, 30 October 2002.

'Call to keep Chaffers simple', The Dominion Post, 8 November 2002. 


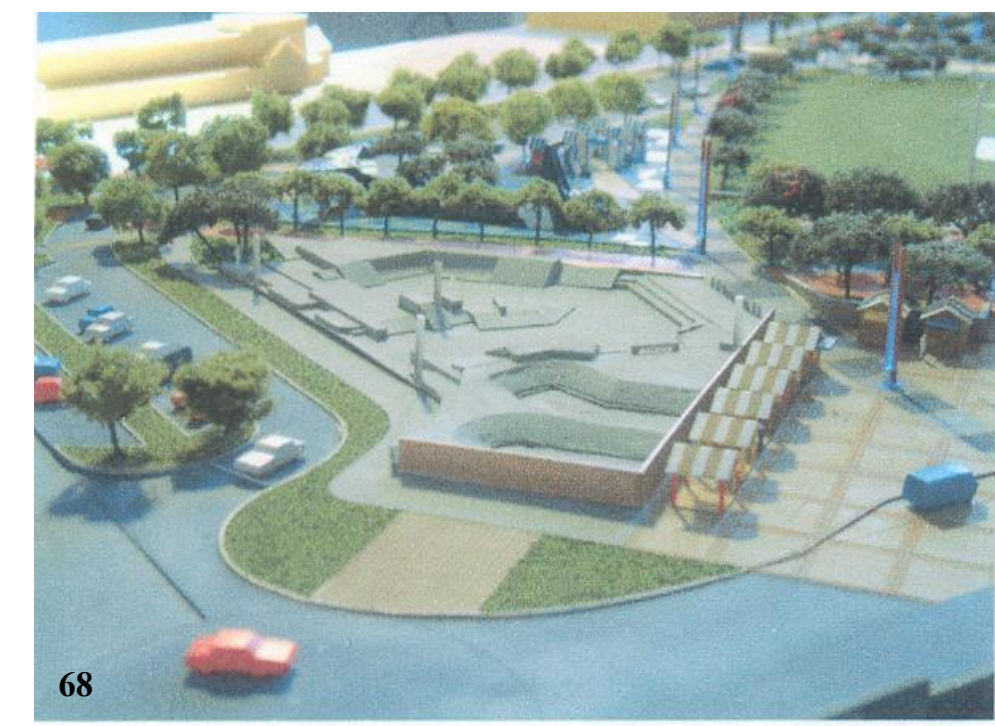

Scheme D

Skateboard Park

Market Square
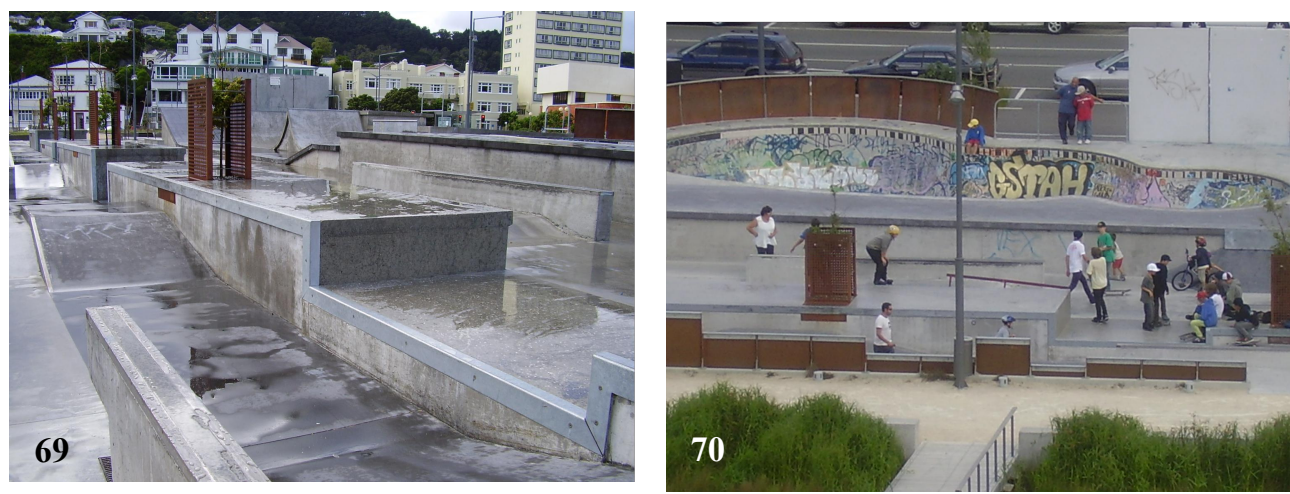

Scheme A

Skateboard Park Waitangi Park

\begin{abstract}
Altogether, Rachel would take some three months of unpaid time to coordinate and write the proposal for the park design with input from all team members. The proposal produced was a 176 page document containing an array of sketches and plans, as well as budgets and concepts. The $\$ 5,000$ awarded to each of the five finalists was put toward making a model. With the Scheme D model, "people could see what they were getting but funnily enough we were criticised by the WCC's Waterfront Development Subcommittee for showing too much detail. They said that it was too prescriptive, but we thought we'd captured the public mood. ${ }^{30}$
\end{abstract}

\footnotetext{
30 'The architect says thanks', The Dominion Post, 6 December 2002.
} 


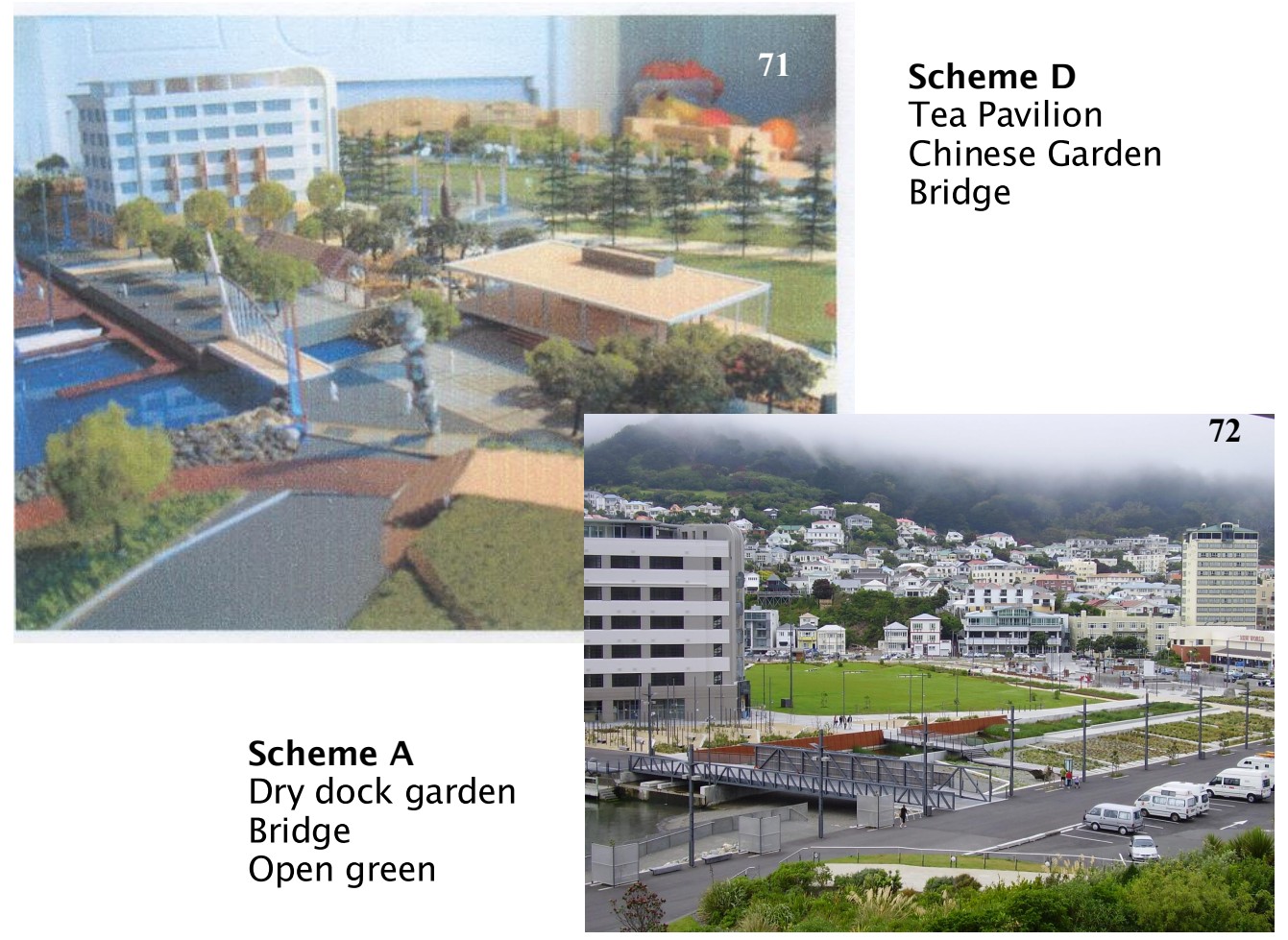

At one point, she remembers being told by a work colleague that there was a possibility the competition was a sham. From that moment onwards Rachel's spirits plummeted. 'I felt the WCC urban designers were the main decision makers in the whole selection process and they didn't want Scheme D because it didn't have the correct style. Nor did it have the additional buildings that they were looking for in that area. I believe Scheme A was always preferred because it did meet what they were looking for and it was pretty similar to their original design from Variation 17 for the Chaffers area. And so I think that the Councillors on the judging panel were somehow involved in the process to ensure that Scheme A succeeded and went through. It's kind of like Council put its own design in the competition and then picked it as the winner.' Rachel was particularly vexed at the way the public's preference for Scheme D had been ignored in spite of the positive feedback the model received in both 'uncontrolled' feedback forms, as well as high rating results in 'controlled' consultation conducted by ACNielsen. This experience was an embittering one for Rachel who subsequently tried to get the daily newspapers involved, but to no avail. They didn't want to know about her concerns over the competition process $^{31}$.

31 Waterfront Watch newsletters, No. 41, March 2002 through to No. 46, December 2002.

'Councillors' choice for Chaffers Park', Contact, 9 January 2003. 


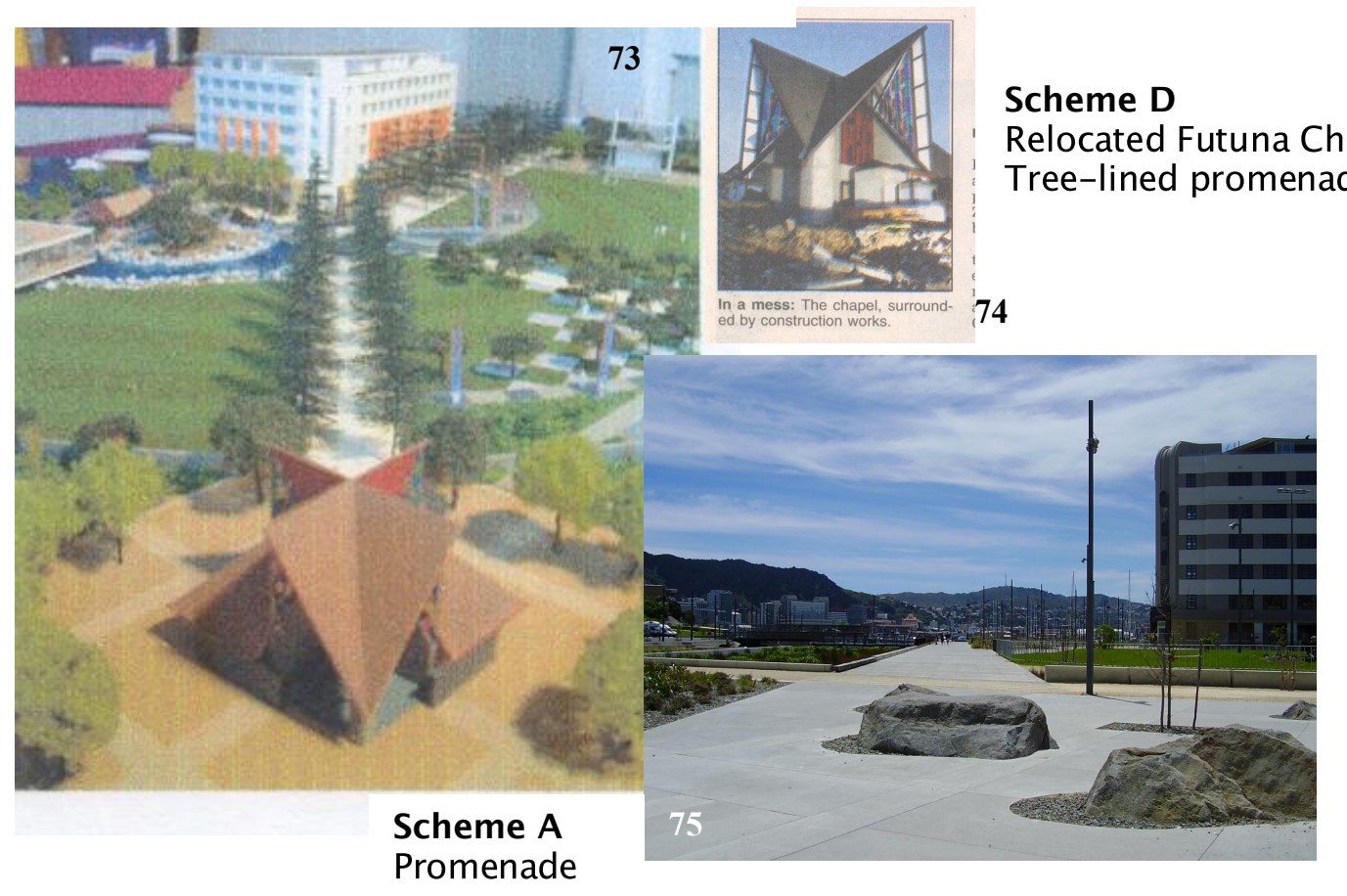

In interviewing the team's architect, Simon Novak, of Novak and Middleton Architects, he discussed the reality of taking part in competitions; how it was a huge financial drain. 'Most of it was done outside of office hours. Various people worked on it and gave their time because they believed in it and found it interesting. We got very close to winning. It got locked into a meeting where, from memory, there was the judging panel with the Technical Advisory Group, a few Councillors, and representatives from the Tenths Trust. Because the Mayor was absent on this occasion it meant that there were only ten people casting a vote, with a split decision being the outcome. My recollection was that a representative from the Tenths Trust decided that it wasn't so much about the design - he could go with either scheme - but that there were other issues more important to him. Some of these concerned the naming of the park. If he could get some certainty from the other scheme that they could be in dialogue over issues, then he was prepared to go either way. At the end of the day he went on the other side and the decision was made. But it was close - then gone.' ${ }^{32}$

\footnotetext{
32 'In a mess: surrounded by construction work', The Dominion Post, 16 September 2002.

'Futuna shift one idea for Chaffers', The Dominion Post, 9 October 2002.

Blunt, Gerald, Chris McDonald, and Tommy Honey (2003) 'Battle of the Backyard' in Architecture New Zealand, Jan/Feb 2003, no. 1, pp.64-72.

'Wellington's Waterfront: A new urban park for Wellington', The Dominion Post, 2 August 2003.
} 


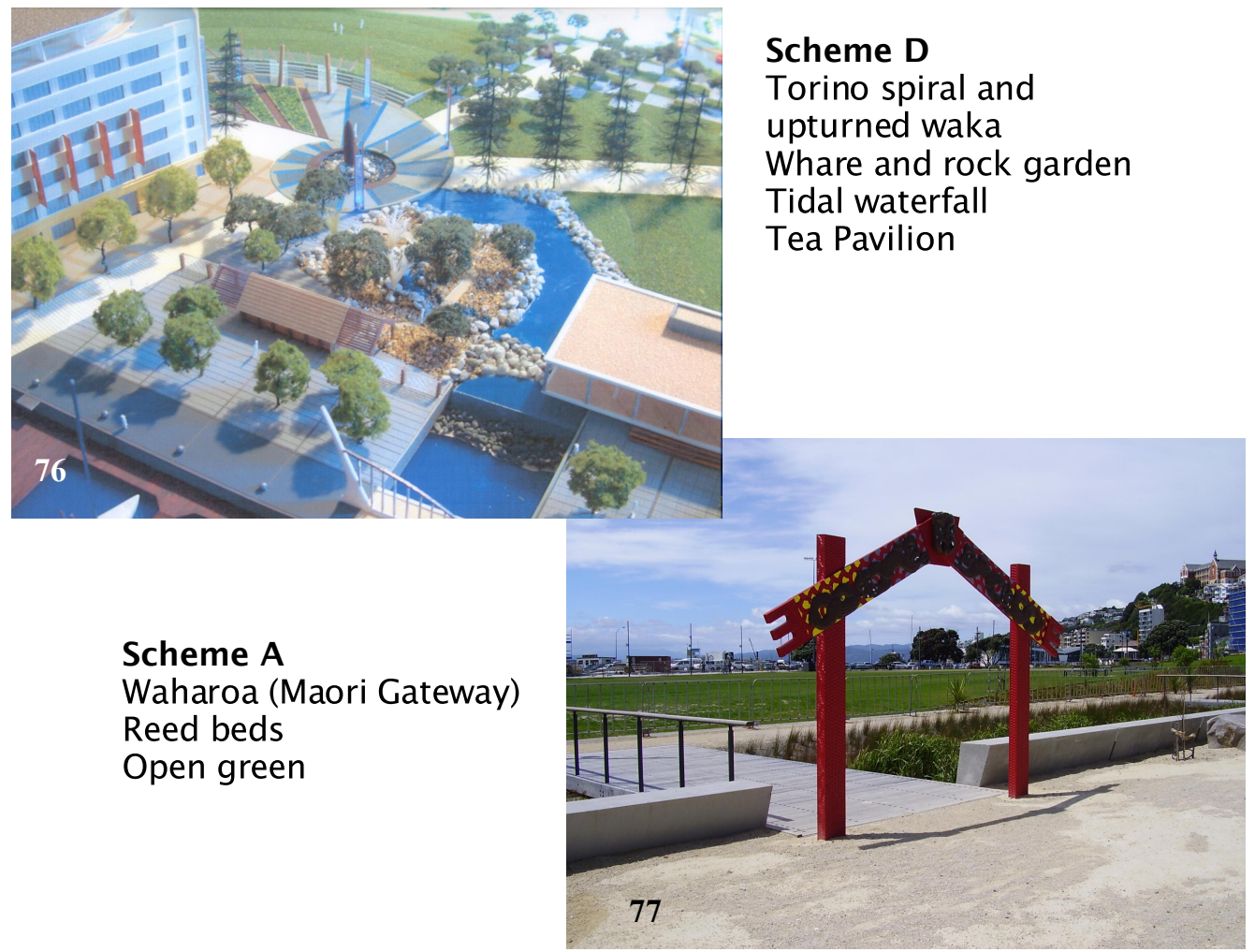

In Novak's opinion, 'if a competition is going to be public then you've got to give the public a voice. The curious thing is that Council needn't have run a competition for the park at all, but at the end of the day it had to consider the influence of ratepayers because interest in the site was so huge. Council rightly realised that the correct thing to do was to allow as many people as possible a say in the matter.' Confusion over the voting process concerned Novak, but not as much as the thought that some of Scheme A's designers might already have been involved in designing a framework and concept for this park prior to the competition. If true, this represented a serious conflict of interest. Any prior involvement with Council work on the park ought to have barred a designer from taking part. Talk circulated at the time, but nothing was ever resolved. 


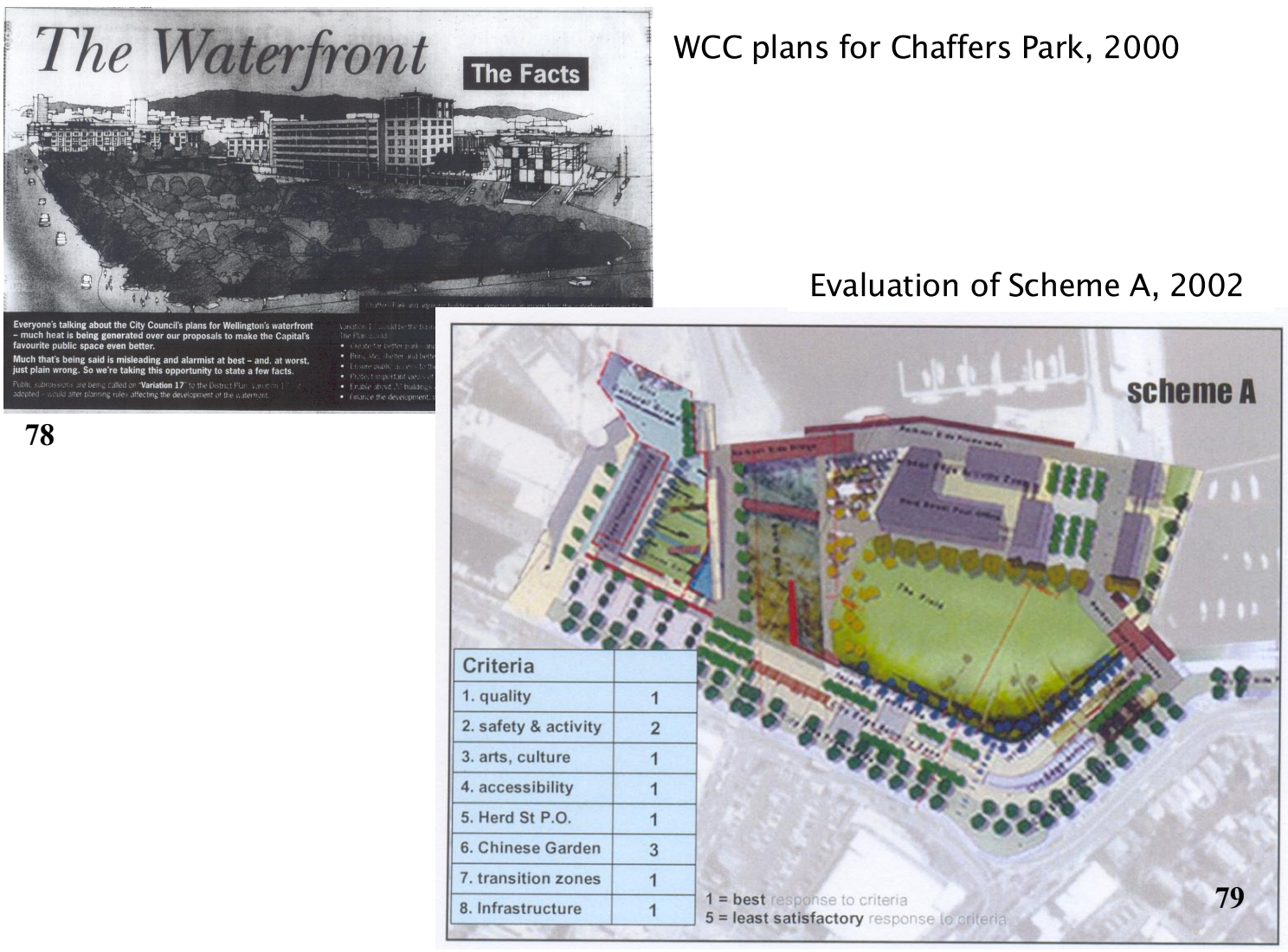

'Why they just didn't select Athfield and Wraight to design a wonderful park, I don't know,' said Novak. 'It would have made a lot of sense to use the same team of designers who had done some very good work on other areas of the waterfront and city. There's nothing wrong with that approach, but to put it into the framework of a competition. If you do that, then the competition's got to be independently run, conflicts of interest declared and removed, which didn't seem to have happened in this instance.' In hindsight, Simon realised that a competitor had to have a good understanding of how a competition was going to be assessed - before entering. They had to know how it was going to be judged and what influence this was likely to have on the outcome ${ }^{33}$.

\footnotetext{
33 'The Waterfront: The Facts' [Wellington City Council], The Dominion, 26 January 2000.

Wellington City Council, Wellington Waterfront Development Subcommittee,

Assessment of Chaffers Design Competition Entries, 20 May 2002.

Wellington City Council, Wellington Waterfront Development Subcommittee, Technical Advisory

Group, Review of Chaffers Park Competition, Stage 2, 18 November 2002.

AC Nielsen, Chaffers Design Competition, a report prepared for Wellington City Council, November 2002.
} 


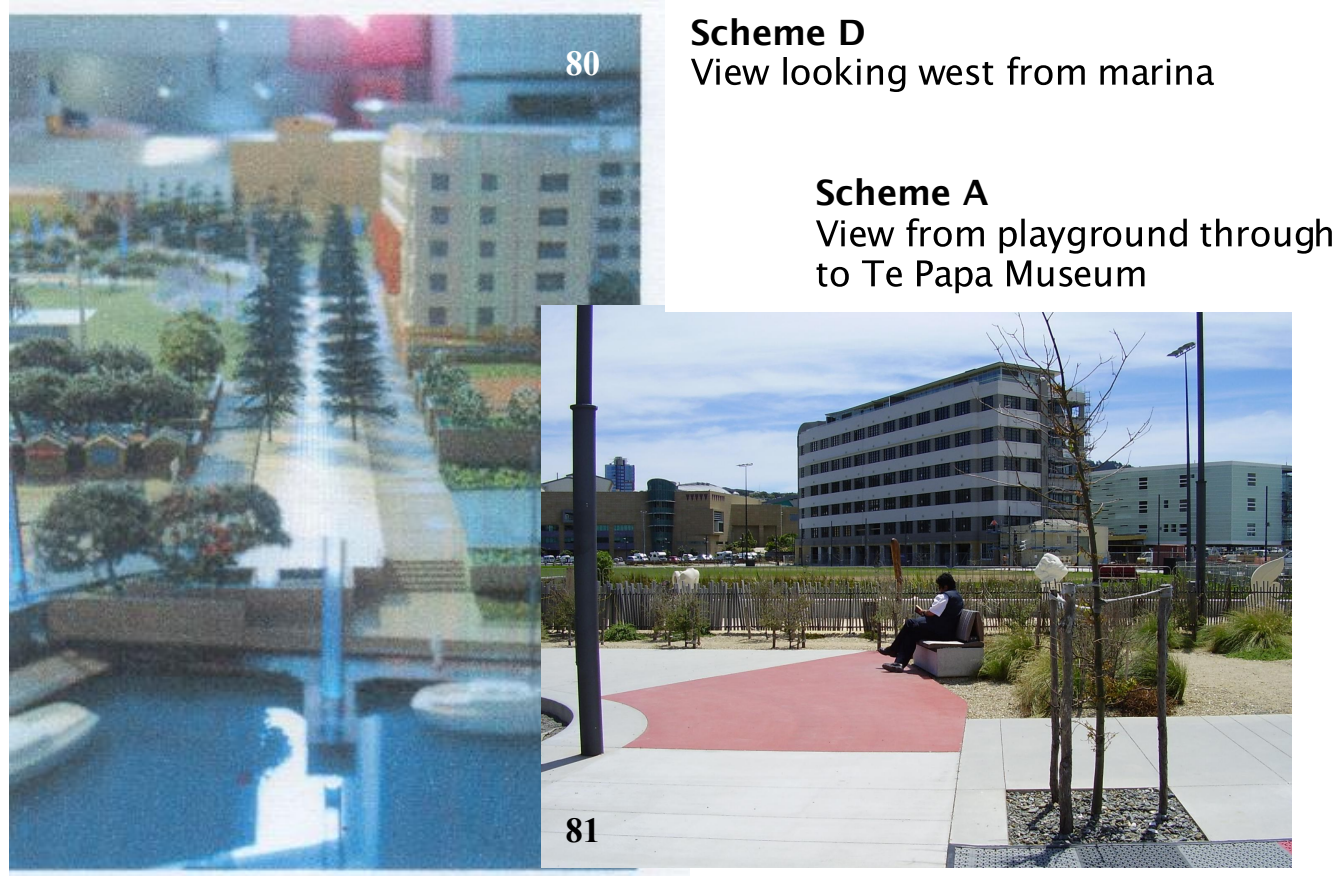

Rebecca Wilson, the landscape architect for Scheme D, and director of Earthwork Landscape Architects, had her own recollections of the competition. She thought winning it would be her big break. 'It was a really big thing to get through to Stage 2 of the competition because we're a small business and small practices don't usually get these types of big jobs. It would have raised my profile and a lot of work come out of it. As it turns out, we're very glad we didn't win because of the drama that went on with the pollution and sub-ground problems. It was really complex, the whole thing, and would have been quite hard for us to deal with ${ }^{34}$. Also I think that if we'd won, we would have been vilified by the architectural community. In asking Rebecca why, she replied, 'Well, it was pretty obvious with the bad press that was thrown through the internet by the New Zealand Institute of Landscape Architects and the New Zealand Institute of Architects that our design wasn't wanted. They sent e-mails out to all of their members, of which I am one, saying this is Scheme D and the reasons it is wrong are $\mathrm{x}, \mathrm{y}$ and $\mathrm{z}$. Please write to the Council and tell them that you hate Scheme D. That you don't want it to win.' 35

\footnotetext{
34 'Suits fly as park builder digs up dirt', The Dominion Post, 26 May 2005.

${ }^{35}$ Excerpt from draft submission to Council e-mailed by Wellington Branch of the NZILA to its membership regarding competition designs and Scheme $\mathrm{D}$ proposal. The final version of submission appears page 35.

- Well made, very clear colourful model.

- Views of the harbour blocked by shelter plaza next to herd St Building and the Chinese pavilion.

- Overuse of clichés/tokenism e.g. paua marking Waitangi Stream has no place in fresh water.

- Main axes all lead into a very tight knot or torino which focuses pedestrians into the Herd Street Building and away from waterfront and corridors through to Oriental Bay.

- Symbolic shape of the torino does not relate to other crucial axes and lines on the site.

- Over use of Norfolk pines forming walkways.

- Design places too much emphasis on the Herd Street building rather than the edge between road and park which is almost all taken up with parking.
} 
WELLINGTON BRANCH OF THE NEW ZEALAND INSTITUE OF LANDSCAPE ARCHITECTS SUBMISSION FOR CHAFFERS PARK DESIGN

The Wellington Branch of NZILA is supports the Process set down by the Waterfront Development Subcommittee, with its rigorous assessment of the criteria as outlined in the competition brief.

The Process must be followed to ensure that the Competition is fair to all entrants We are concerned that the Process could be subverted by strong lobby groups, whose decisions are not based on the design criteria..

The Branch believes that the Technical Advisory Group is the body that is best placed to provide guidance on the Chaffers Park Design to the Waterfront Development Subcommittee in their final design selection. TAG group members possess a wide range of urban design expertise, and have an in-depth knowledge of the site, the issues and the design criteria.

Model Making Technique:

We note that different presentation styles were employed for each model, especially in the representation of the buildings and existing features. A strongly realistic model eg Scheme C may have been more legible than Scheme $E$, where a more conceptual style was employed.

We feel that this may have a strong influence on the submissions, particularly for members of the public who are not well versed in reading plans and who therefore used the model for their primary communication.

In retrospect, submissions may have been more balanced if one model maker had been employed to construct all models.

Preferences

A survey of Wellington NZILA Branch members indicated that:

- Scheme A is the preferred design. Respondents felt that the designers have shown a sophisticated understanding of the site. The design is fluid, flexible and would endure over time. The design showed several layers of interpretation thus enabling the widest range of users to comfortably enjoy the park.

- Scheme D was definitely the least preferred with most respondents ranking it lowest. It was felt that this design lacked flexibility, restricted accessibility around the site, and was likely to date over time.

- Schemes $B$ and $C$ ranked about equal as the second or third most preferred design. Responses for Scheme E were polarized; members either liked it or strongly disliked it.

Yours sincerely,

Angela McArthur - Branch Secretary

Email; angelamcarthur@paradise.net.nz

Secretary Wellington Branch NZILA,

4 Kohima Drive, Khandallah, Wellington.

(on behalf of the Wellington Branch of the New Zealand Institute of Landscape Architects)

These documents corroborate Wilson's claims. They also support Shelton's belief that a public vote had been anticipated, with professional institutes having the same impression. In this submission to Council, the Wellington Branch Secretary of New Zealand Institute of Landscape Architects relates its membership's preference for Scheme A, and the reasons behind this choice. It cites Scheme D as being the least preferred and lowest ranking design proposal amongst those who responded to the institute's in-house survey. It also mentions lobby groups being powerful enough to subvert the outcome of the competition, while ignoring its own potential influence. 


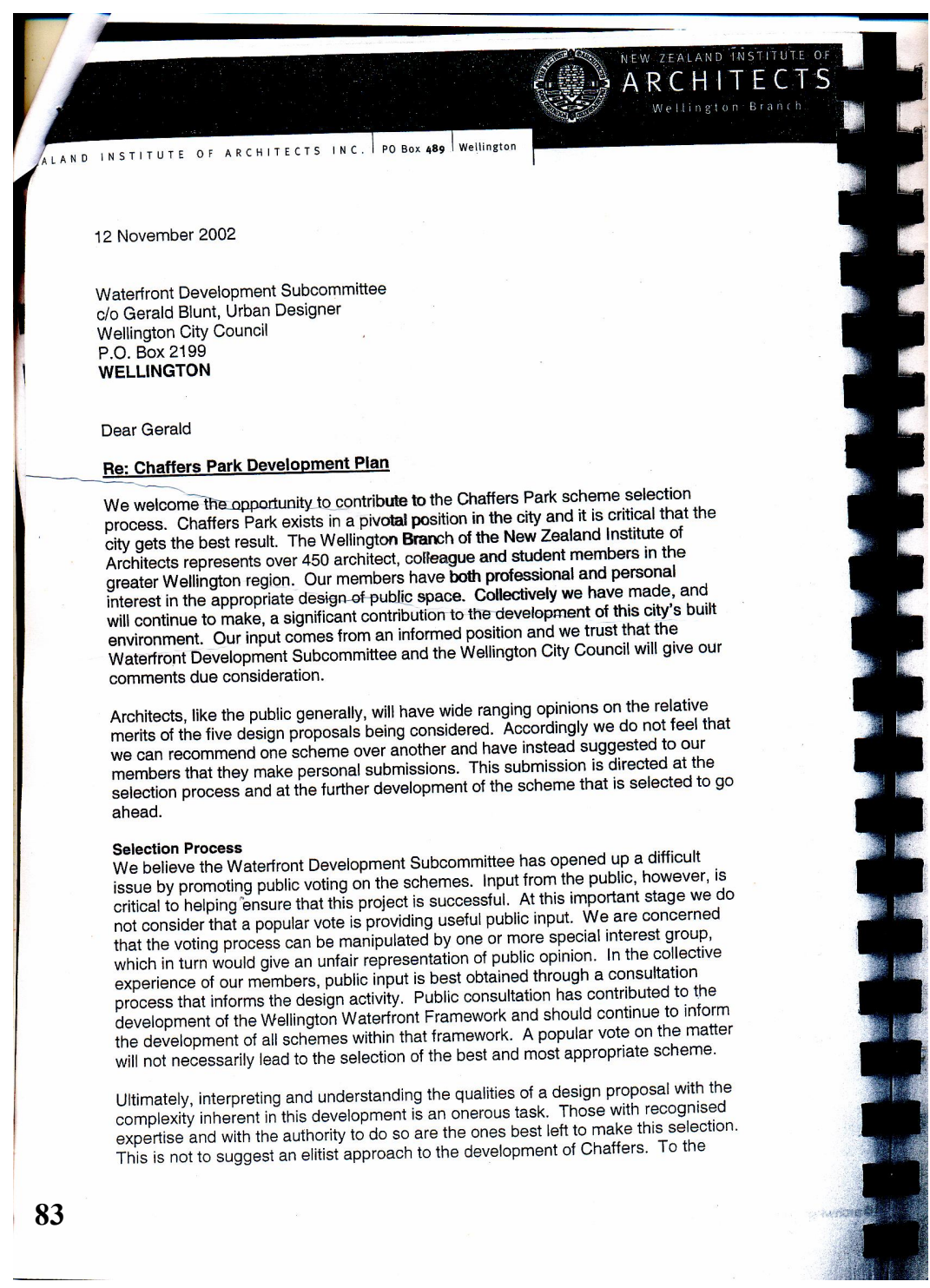

The second document, a three-page submission from the Chairman of the Wellington Branch of the New Zealand Institute of Architects to the WCC's Waterfront Development Subcommittee, notes that allowing the public to have a say in the final selection of a park design would be detrimental. That a popular vote on the matter is a poor idea because, although the public's input was needed to make the park successful, it might be open to manipulation. That special interest groups could well use the opportunity, giving an unfair representation of public opinion in the process. Under these circumstances, public input should be minimised to consultation alone - as was the current practice. 


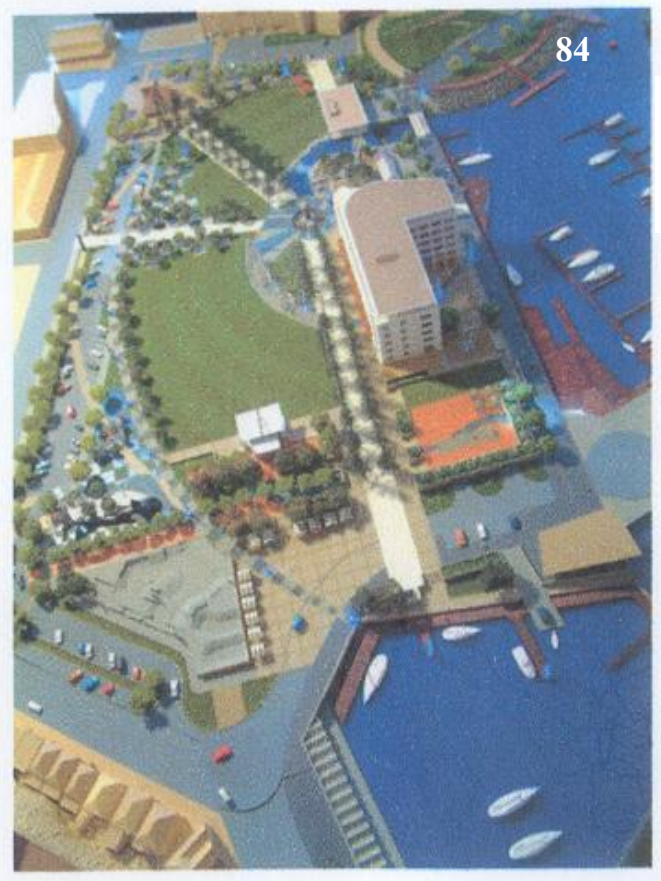

\section{Scheme D}

Aerial view looking west

\section{Scheme A \\ View from marina}

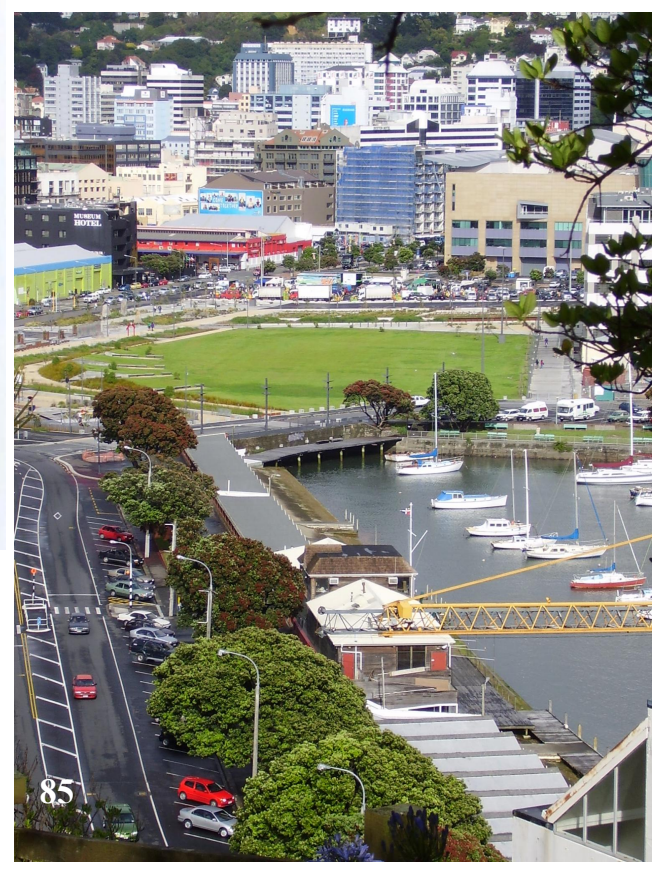

Rebecca was furious with the NZILA for interfering and showing such bias. 'It was a serious turning for me,' she recalled, 'I just really wanted to run away from the project and didn't want anything more to do with it. If that was the sort of stuff that was going on. It was very blatant - obscene in my opinion. I was very upset and really traumatised by the sort of hate campaign against our scheme. I wondered why they were being so awful about it. When asked why she thought the competition had been run at all, Rebecca replied that it was done as 'a bit of a PR exercise to make everybody think that they were involved.' 

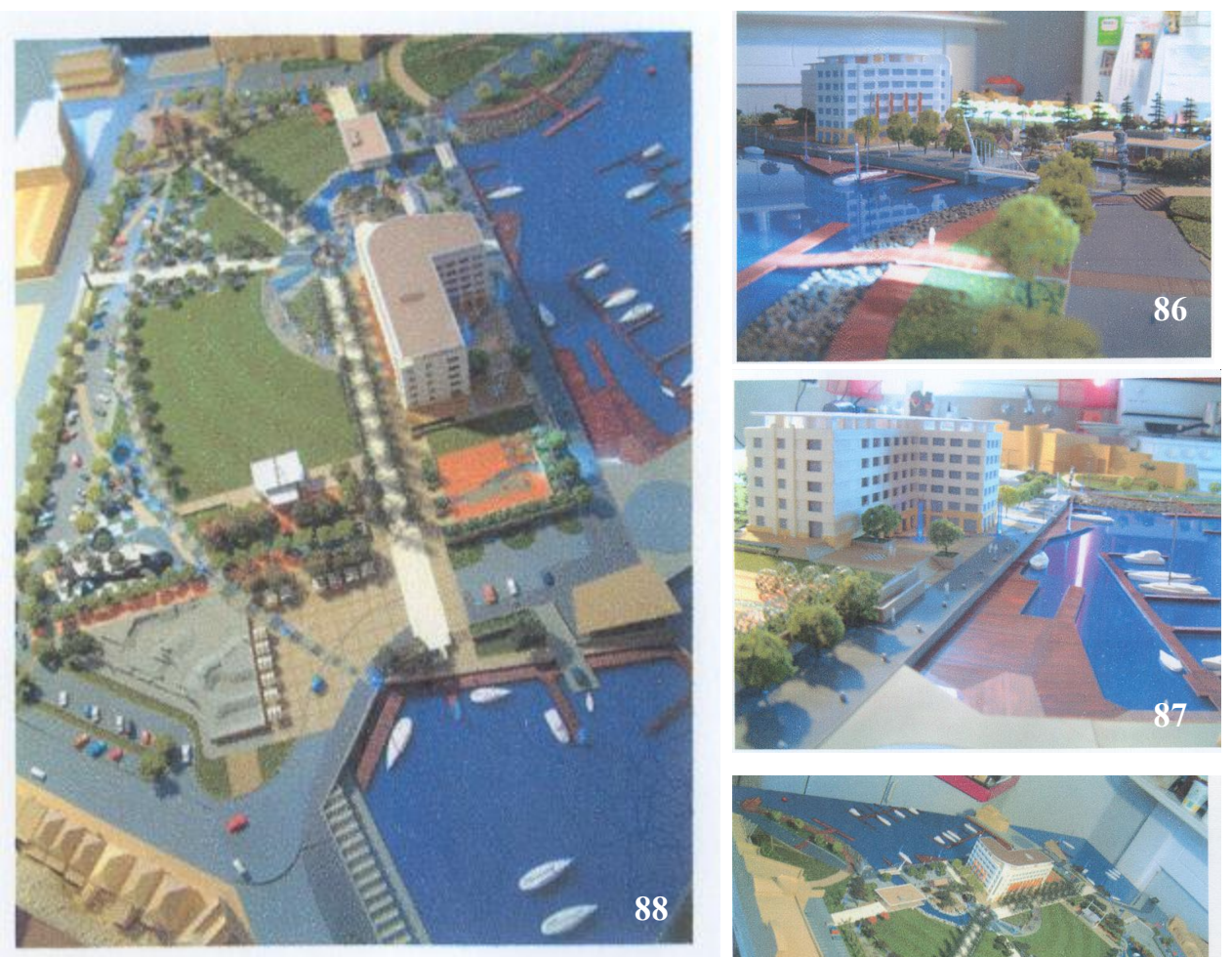

Scheme D model

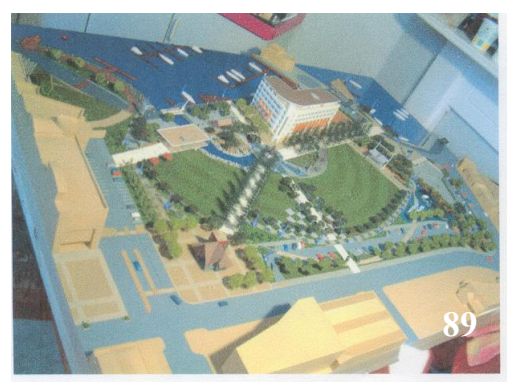

'I believe Council was paying lip service to the public interest and trying to sort of get what it wanted. Definitely steering the outcome. But the thing that brought us down was our model. Believe it or not, we were criticised for ticking all the boxes. We hadn't left any empty, formless spaces, no areas that were unspecified and unused, no wishywashy bits off to one side that could later have a building on it, or some other thing. 36

\footnotetext{
36 'Park building plan faces fight', The Dominion Post, 5 May 2003.
} 

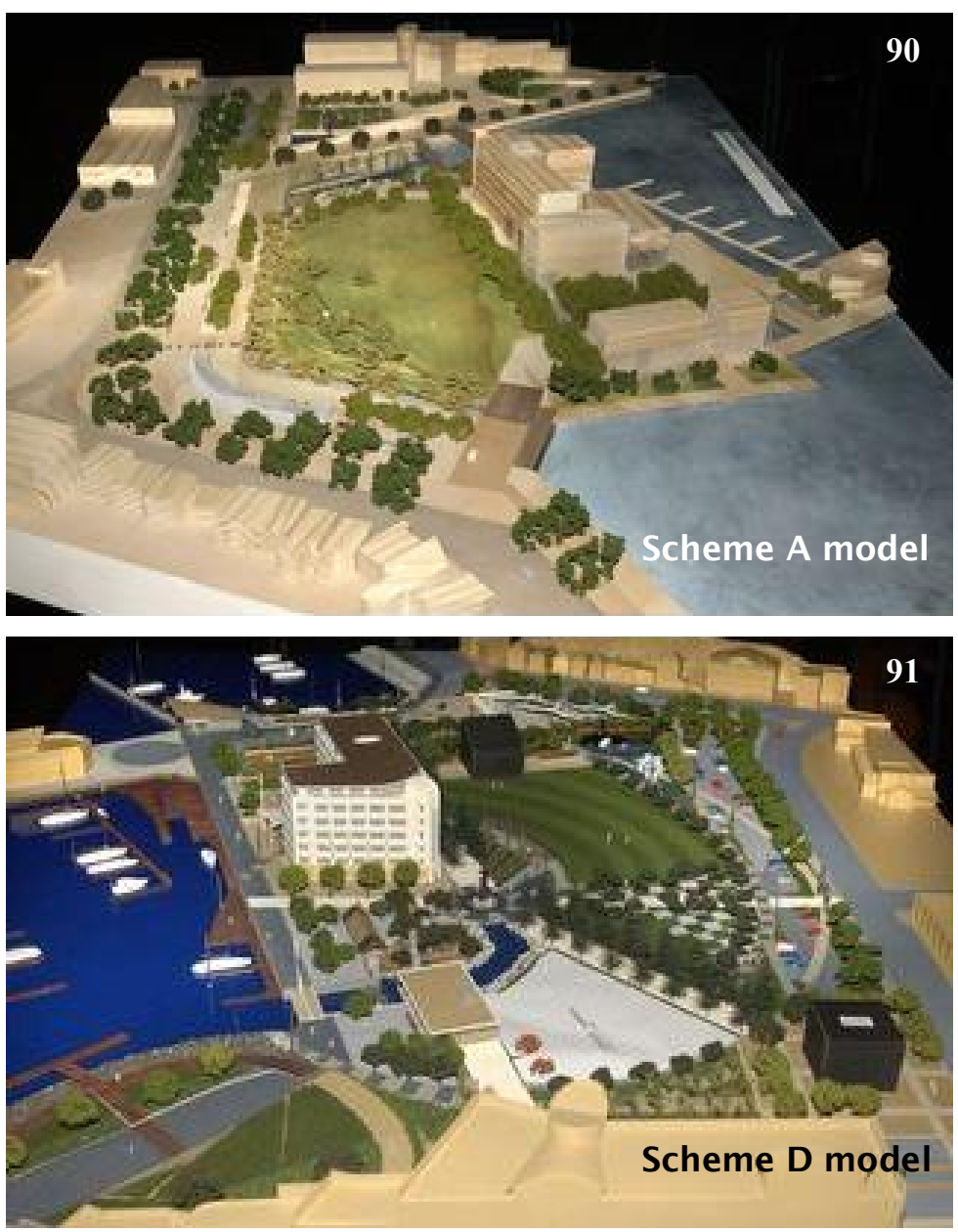

In terms of the model, 'we over-designed it,' she said, 'we went too far down the track. We showed too much and got too carried away with the detail instead of keeping it conceptual. Council inferred the public had voted for our model - not the design. In comparison, Scheme A's model was rough. 'If it was hard for an experienced designer like myself to tell what was being suggested, then you can imagine why the public wasn't immediately drawn to this design. Too much was being left unspecified.' Rebecca believed the Scheme A model was a bit of joke. They knew their design was going to get in so why waste money and effort on it. And, 'suddenly we came along and the public loved us. So then they had to start bagging us and sending out the bad press and rigging the results and accusing us of stealing voting forms.' 


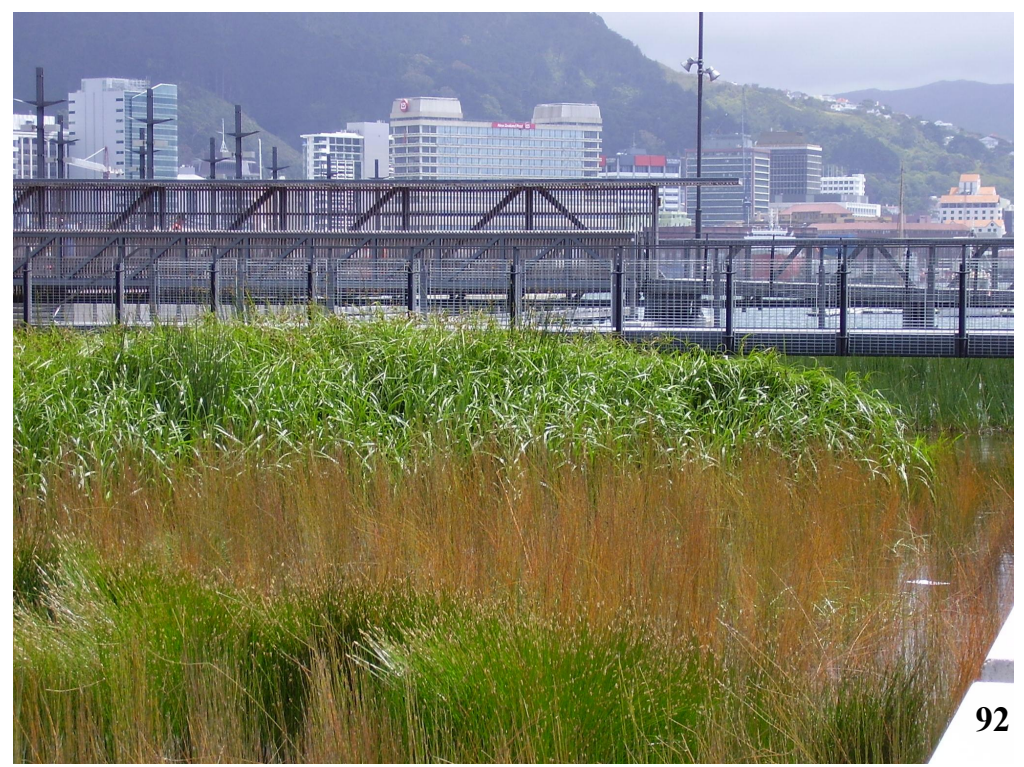

When asked whether Rebecca did any work for Wellington City Council now, she replied, 'Not really, no. They have their own inhouse landscape architects that tend to do things around the place. And Megan Wraight gets most of the other work.' This implied that certain designers carved out patches for themselves in a city, and that others in the same field recognised this and stood aside. 'And really, I can't be bothered with the aggravation of trying to win something that I don't have an outside chance of doing. I can't get hot enough around the collar to put up a struggle. If I thought she was doing a terrible job, then I might put up a fight. But I actually like what she does. Besides, I'm not a minimalist; I prefer to get work that celebrates nature a bit more, rather than celebrating man's domination over it, that sort of thing.' 


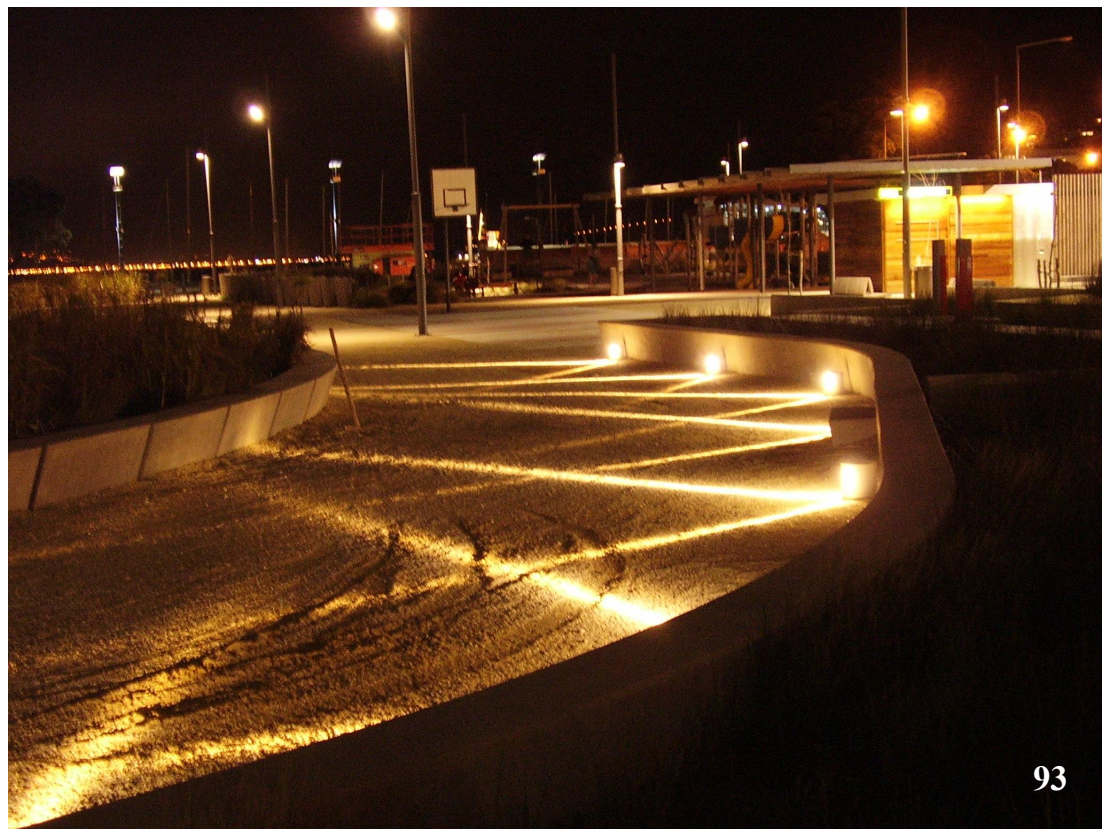

Council appeared to be branding Wellington with a certain civic look that only some designers were thought capable of providing. As to consultation processes, Rebecca saw them as a necessary evil. 'I don't think there are many designers who would honestly say that they want to do just what the public wants. They mostly go, "Oh god, we have to go through this public consultation process." And if there's ways that we can incorporate the public's requirements and desires, without upsetting what we really want to do as designers, then there are many times where you can incorporate what they want. But there's not very often where you go to the public consultation process with no prior idea of what you want to do and say, "Come on guys, bring it on. We'll do what you want.", 


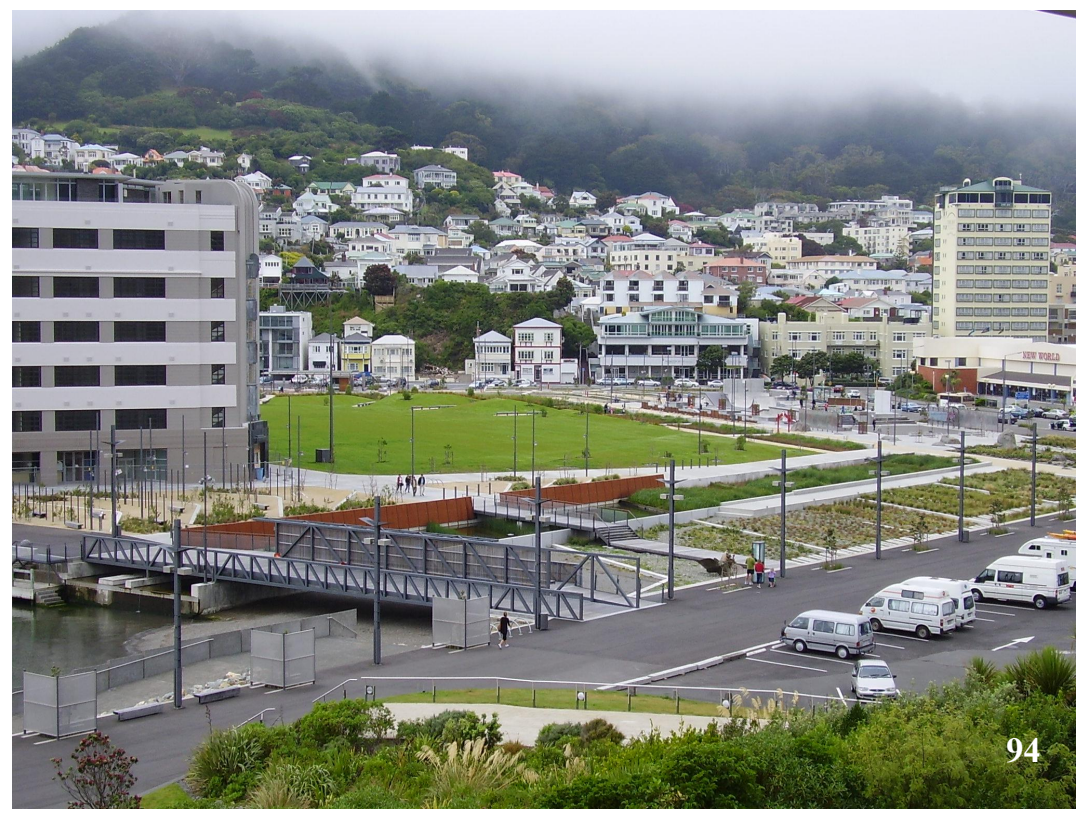

This was bad news for all those who thought they were taking part in an equitable process and a far cry from the hope and dynamism associated with the Wellington Civic Trust's Harbour City Competition in 1983. Robin Boddy, an engineer, had a clear recollection of this event. He got interested in taking part and drew up a proposal for the waterfront only to realise that in order to qualify as a competitor he would have to find a firm of architects to go in with. Robin located one and they cobbled together a design, submitting it at the last minute. All the entries were presented in a public exhibition which he also attended. He spoke of the occasion with fond memories. 'Do you remember the old city art gallery? They had the competition entries jammed in a little room upstairs. It was hot and stuffy and everyone was packed in there. But it was great to see your things pinned up on the wall of an art gallery. I've still got my drawings.' And although his vision failed to win the competition, Robin didn't really mind. 'I think it was a fair outcome,' he said, in speaking of the Paperchase Group's winning proposal. Twenty years between public design competitions had seen quite a different set of experiences emerge, bringing to a close this version of the story - except for one small point ${ }^{37}$.

\footnotetext{
${ }^{37}$ Wellington Civic Trust (1982/3) Harbour City: New Ideas for One of Wellington's Finest Assets. Wellington Civic Trust (1983) Harbour City: Blueprints for the Future; Winning Entries in the Wellington Civic Trust Harbour City Competition.

Wellington Civic Trust, newsletter July 1983.

Wellington Civic Trust (1984) Harbour City: Ideas for Action: Proceedings of the Harbour/City Conference, 4-5 July 1984.
} 


\section{8 weeks to design quayside}

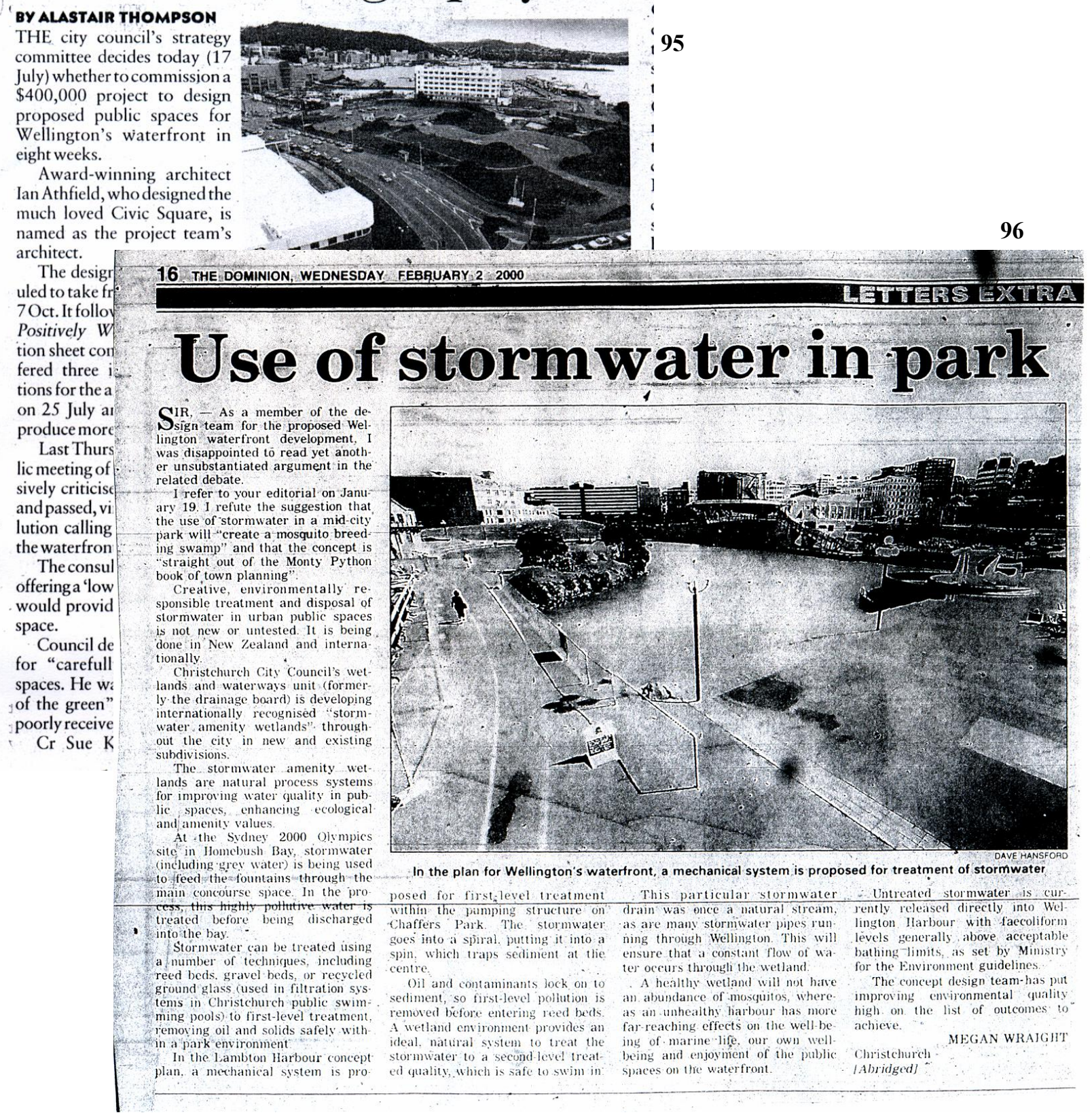

In the uppermost article, Ian Athfield is named as project team architect for an eight week redesign of Wellington's waterfront, in 1997, by Wellington City Council. In the second, Megan Wraight writes, in 2000, of being a member of the design team working on the Chaffers Park site. This meant they were very familiar with Council's expectations for the park, making for an uneven field of competitors. Whether Athfield was personally involved in this event is unclear, though members of his staff obviously were. The competition itself was held beginning in late 2001, with the judging done in November of $2002^{38}$.

38 'Eight weeks to design quayside', City Voice, 17 July 1997.

'Use of stormwater in park', The Dominion, 2 February 2000. 


\section{First Evaluation}

In beginning the story of Waitangi Park and the Chaffers Park Design Competition with this particular version of the story, my intention was to provide the reader with an unusual starting point from which to base their judgment of events. By allowing the background history of the site to be retold from the perspective of lobbyists, and the runner up in the competition, a disruption in understanding is set in motion.

First, the rather simplistic notion that Waitangi Park was created through the Chaffers Park Design Competition is set aside. Mary Varnham puts us straight on this account, reminding readers that the park was in fact the result of intense public lobbying aimed at keeping the site in public hands rather than being privatised by Council for the purposes of housing, commercial retail outlets, and a pocket-sized park. She rightly pointed out that the quest to create a park on the Chaffers site went back to the 1930s, well before lobby groups 'Waterfront Watch' and 'Chaffers Park - Make It Happen' existed. So in a sense, the vision for an open, green space was already there in the minds of Wellingtonians, lobbyists merely tapping into what was a pre-existing wish and using the resulting groundswell to secure the future of the park. This explained the massive turnout at meetings and the generosity the public displayed in contributing to fundraising appeals, outpourings of support that both surprised and delighted lobbyists. Picking up on the depth of emotion for this popular cause, lobbyists were able to use this concentrated power to force Council into taking up the park idea instead.

However in rejecting Council's plans, the public appeared to be backtracking on a more recent vision for the area, a design coming out of Wellington Civic Trust's 1983 Harbour City Competition. Although considered a good scheme at the time, with the realisation that public land would need to be privatised in order for this to come about, the public abruptly changed its mind. It dawned on them that without immediate intervention, the possibility of getting a large park on the site was about to be lost forever. The resulting debate reflected a division between Council and the public's vision over what was needed in this space, and about who had the ultimate say in the way public land was used. This situation also highlighted the tension between acts of founding and preservation, and how interest groups aligned themselves on one side of a conflict or another depending on their preferred outcome.

Because resistance against Council plans was of a piecemeal nature, with some projects being opposed while others went ahead without any trouble, this drew attention to the special value Wellingtonians accorded the Chaffers site. This was somewhat hard to fathom, given the neglected nature of this place over the years, having been a scruffy industrial area and unsightly Corporation Yard for decades. Somehow the vision for an open, green space was retained and considered worth fighting for in this instance, which explained why people came out in force to insist upon a park. However, it would be true to say that without the commitment, skill, and concerted effort of lobbyists, this dream was unlikely to have come to fruition. So by rights, the presence of the park is due to the insight of groups like 'Waterfront Watch' and 'Chaffers Park - Make It Happen', though 
others were instrumental in preparing the groundwork, such as the Wellington Civic Trust.

In placing so much emphasis on the political aspect of the park's creation, this relegates the design competition to a more secondary position. But for those involved in this event the demands were equally intensive and formidable, making 'it' the centre of attention. Their focus was almost exclusively on the creative process apart from a bit of background context, the convoluted politics behind the entire waterfront redevelopment being too much for most people to encompass. Because the debate extended over several decades, with few people being fully conversant with all the ins and outs of events, this would prove detrimental. The minutia was overwhelming, making it hard to grasp the bare bones of the matter, yet to be unaware of the growing mood of opposition between Council, lobby groups, and the public was to leave oneself unprepared.

This lack of forewarning would have a more devastating effect on designers than lobbyists who, after all, had more political experience though even here they weren't entirely immune to naïve assumptions about power sharing. In looking at the runner up's design proposal, and their perceptions of the process as it evolved, a good appreciation of their involvement is gained. Equally, in making use of visuals depicting their scheme, the reader gains a better appreciation of what other park possibilities were possible. This comparison between what is there now, and what might have been, gives us a rare opportunity to understand how engineers, landscape architects, architects and designers think and react in political situations. The fact that Scheme D appeared to have won the public's approval, yet lost out because of Council's experts being against it, was a blow. But not as great a one as finding out that the competition might well have been a sham; this was truly devastating. Anomalies in the competition process started to mount up with each of the interviews I conducted, making this version of the story particularly sensitive because of the allegations brought forward.

This situation made me think about Council's remarkable ability to capture ideas, how it could get people to willingly offer up concepts for no recompense in most instances. Because only one entry could win a competition, this meant that all the other contributors were automatically losers whose visions were basically unwanted. These superfluous proposals represented countless hours of work and considerable financial input, making me wonder why designers did it over and over again. The status accorded a win and the excitement of taking part accounted for the big turnout, but didn't explain everything. To throw one's hat into the ring for the sheer exhilaration of competing and pulling out all stops in the process was understandable, so too was the disappointment and disillusionment in realising that an injustice might have taken place. And although Scheme D's loss looked to be undeserved, Council would have no trouble rationalising this decision. 


\title{
Middle Way
}

\begin{abstract}
$\boldsymbol{T}_{\text {he term middle way refers to the }}$ mid-course in any journey. It also represents a course of action between two extremes. At the halfway mark, a certain type of play is expected. Here wrestling over differences and contradictions takes precedence.
\end{abstract}




\section{From the Ideal to the Unmentionable}

\section{The Wellington City Council's Perspective}

Wellington City Council is an organisation that sees itself as passionate, hard working and committed to making the city a great place for residents and visitors alike. In order to communicate the work it undertakes, as well as its plans for the future, advertisements are at times taken out in local newspapers. The one below appeared in the 'City Voice' in 1997.

\section{Lambton Harbour consultation ... the Design Team reports}

\section{The story so far...}

Wellington City Council has been consulting with the community over the next stage of the Lambton Harbour Project for over a year.

Throughout the consultation the people of Wellington have asked for a high-quality waterfront, led by superbly designed public space.

To achieve this, a team of top architects and designers have worked on a Design Concept since August. They presented their first "work in progress" for public comment in September.

They are now ready to present their finished design ideas to the community and the Council.

Come and see for yourself! Monday, 20 October, 7pm, Ilott Concert Chamber
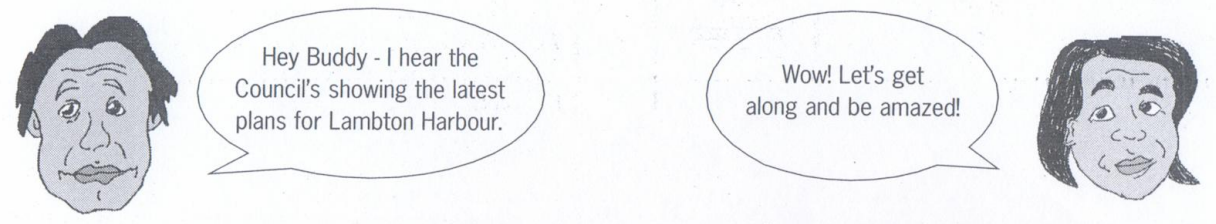

LAMBTON HARBOUR CONSULTATION

Design Team Reports

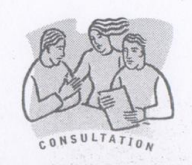

Through its content and tone, this advertisement gives a good indication of Council's intent to communicate in a factual and forthright manner that is at once decisive yet remains approachable. Here, the public is informed of what has transpired, how events ought to be understood, and where input would be most appreciated. The most striking aspect of this document is not so much the information conveyed, but the facts that are left out for the sake of simplicity and clarity of purpose. Complex political situations are pared down to their minimum, with hints of a debate scrupulously removed so that any tension that exists between founding and preservation in Council's work is not made visible. By sticking to the immediate present uncomfortable events are skirted, allowing a brighter viewpoint to assert itself. And when past events are permitted to emerge, a concerted effort is made to circumscribe details in such a way as to make them accord more closely with future directions and policies. So an ideal was at work, one that answers to a higher conception and bespeaks Council's particular vision for the city which could be described as aggressively positive. 


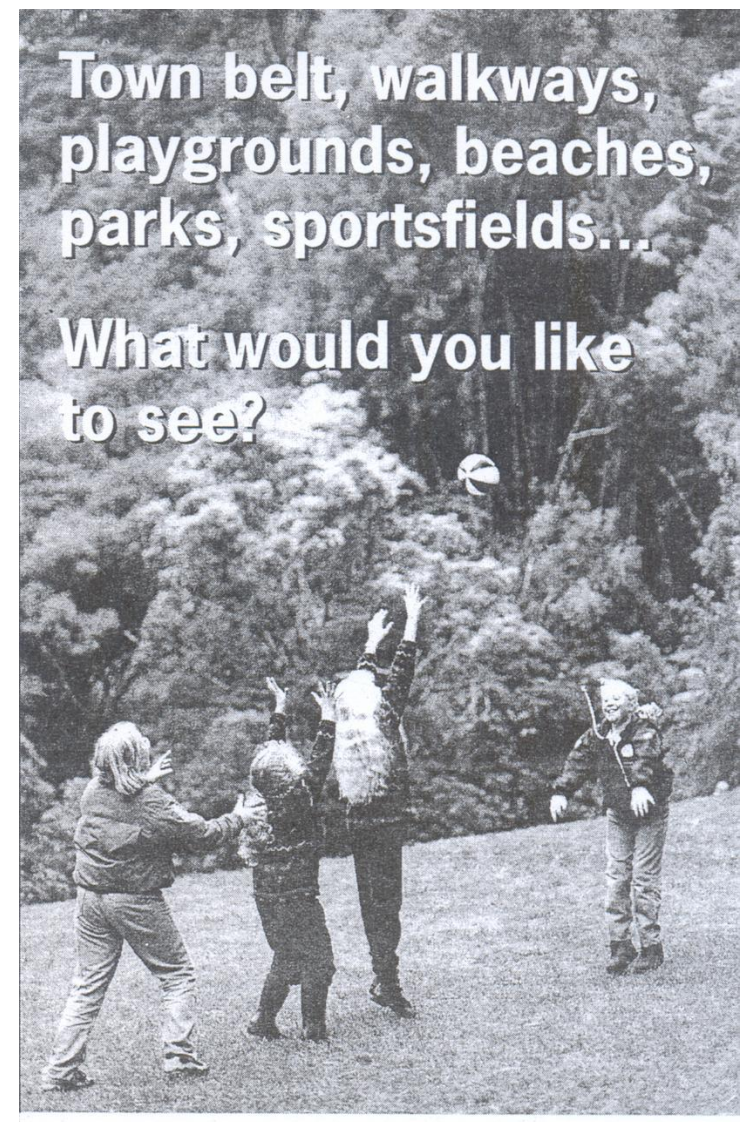

You can comment on the Council's draft Open Space Strategy. Your feedback will help.

Please send your comments by 26 August 1998.

Contact Hugh Nicholson for a copy:

PO Box 2199, Wellington.

Phone: (04) 8013632

Fax: (04) 8013231

Email: hugh.nicholson@wcc.govt.nz

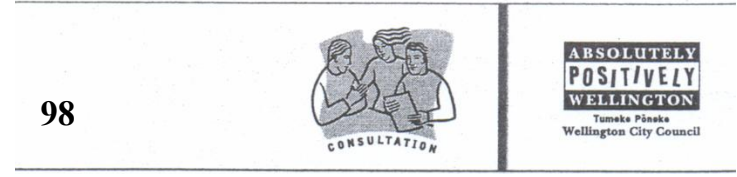

In order for Council to get people's support for its plans, the public must somehow be made to accept, or readily buy into, their initiatives and strategies. It is incumbent upon Council to marshal the resources necessary for making its ideas a reality. Because standards of excellence are a top priority, when the best option is indicated for some project, there is little room for doubt left. A preferred route to cooperation is selected, and pushed, until a satisfactory outcome is achieved. Sometimes the messages used to implement desired outcomes can be simple, other times much more comprehensive in content. In the example alongside, the public is asked to engage with Council and help it decide what needs doing to Wellington's open spaces to make them better places. People are given the opportunity to comment, or supply feedback, which Council then takes upon itself to consider. Taken at face value, there is orderliness and equity in this process in that an effort has been made to consult with stakeholders in order to assure that what is most needed, and wanted, is implemented. When the situation warrants, more prominent notices are placed in newspapers that contain greater detail, sometimes taking up single, and double-page spreads, as needs be. This is done to circumvent, or nip in the bud, misunderstandings that might otherwise cause damage to upcoming projects that require public support in order to be enacted.

In the troubled times between 1996 and 2001, a number of rallies and protest meetings were staged in Wellington, demonstrating the public and lobby groups' hostility towards Council's plans. Once the moratorium, brought about by Waterfront Watch, was lifted on waterfront development Council found itself in a position of rebuilding bridges, having alienated the public. The new Mayor, Kerry Prendergast, had a direct approach which she made sure was reflected in Council's actions. In her words, 'there was a feeling from Councillors that we had abdicated our responsibility for some time anyway, and when were we going to take the reins back and make a decision.' (City Voice, 9 October 1997). 
This forthrightness is visible in the advertisements placed by Council in local newspapers, which used an authoritative tone with the public, as though chiding it for being willfully uncooperative. A summary of its contents is offered on the next page, the print being a bit too unclear to read comfortably.

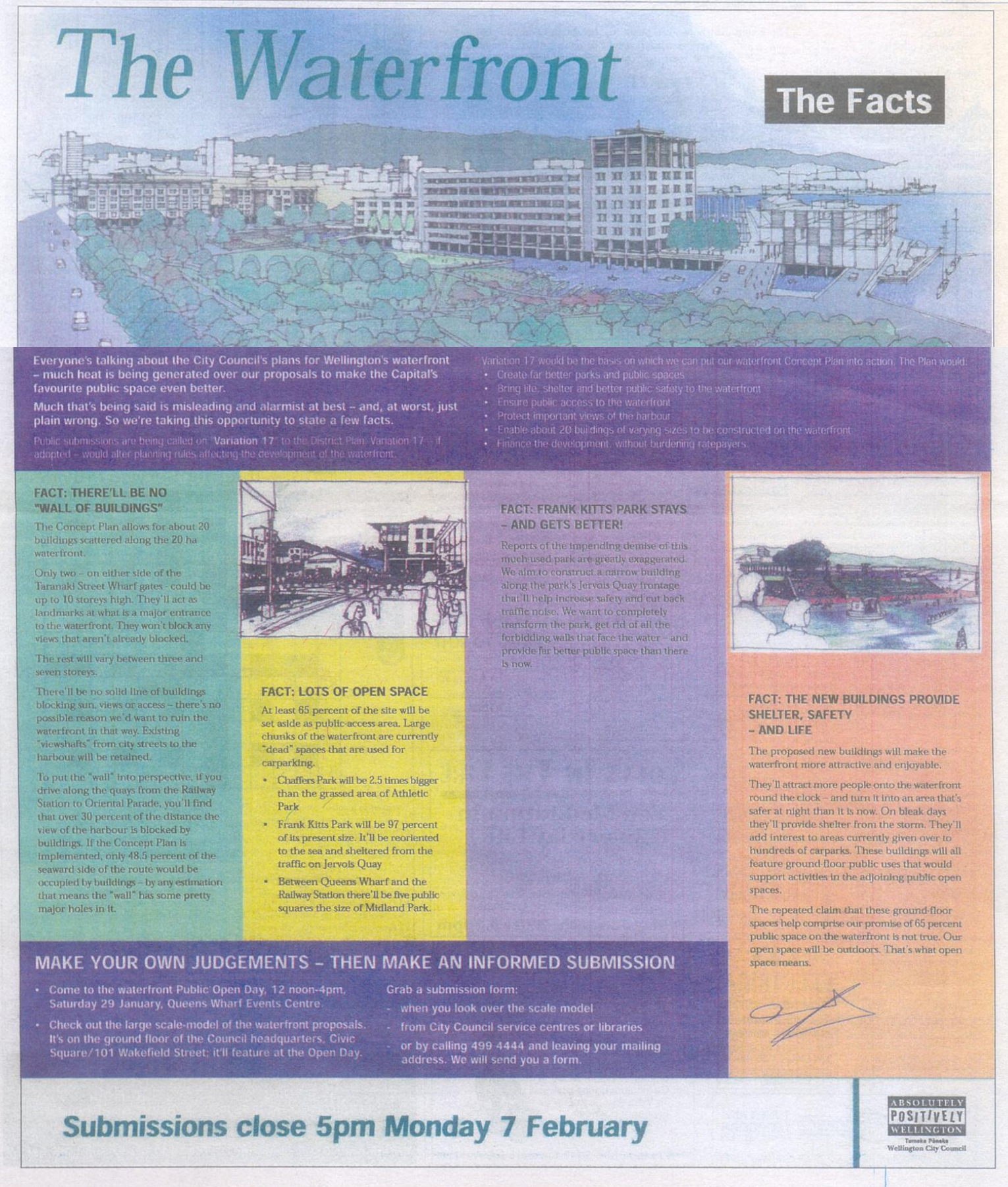


As published in the City Voice, 27 January 2000.

\section{The Waterfront: The Facts}

This bold, and colourful, announcement begins by noting that everyone in Wellington was talking about Council's proposals to make the Capital an even better place through its plans for the waterfront. How a great deal said by detractors was not only misleading and alarmist in this case but just plain wrong, making it necessary to put things right by elaborating upon a few key facts. In smaller type mention is made of Variation 17 and of how, if adopted, it would alter planning rules affecting the development of the waterfront - for the better. This variation on plans was intended to serve as the basis upon which 'we', meaning the public in cooperation with Council, put the Concept Plan into action with the benefits accrued being the:

- Better parks and public spaces

- More life, shelter, and better public safety to the waterfront

- Public access to the waterfront

- Protection of important views of the harbour

- Enabling 20 buildings, of varying sizes, to be constructed

- Financing of this development without burdening ratepayers.

\section{Fact: There'll be no "wall of buildings"}

The new buildings proposed would be scattered along the waterfront over a 20 hectare area, with only two of them envisioned as being more than 10 storeys high. Because the intention was to make these landmark structures serve as entry points to the waterfront, the issue of affecting views was somehow mitigated, the inference being that structures would not be obstructing any views that weren't already blocked. The remaining buildings would vary in height, between three and seven storeys, meaning that no solid line of buildings would either deter access or block the sun. Nor was there any plan to ruin the waterfront by doing so, the intent being to safeguard and retain viewshafts that already existed. Some useful statistics regarding what was already on the waterfront are presented, the point here being that major holes would always exist between buildings, thereby ensuring some prospect out to the harbour in any event.

\section{Fact: Lots of open space}

Some $65 \%$ of the waterfront site was to be set aside as public-access area as a way of ensuring that "dead" spaces, of which there were large chunks, would be used for other than just parking. As part of this plan, the Chaffers Park area was to become 2.5 times bigger than the green of Athletic Park, with Frank Kitts Park only being subject of a 3\% reduction in size through a judicious reorienting of the site. Five new public spaces were being planned for the area between Queens Wharf and the Railway Station whose size was estimated to be roughly that of Midland Park, a local landmark most Wellingtonians would be familiar with.

Fact: Frank Kitts Park stays - and gets better

Council noted that the report of Frank Kitts Park's demise had been greatly exaggerated, that in re-orienting the park to face the water rather than street, it would become a much better public space. 


\section{Fact: The new buildings provide shelter, safety - and life}

In defense of the new buildings proposed, these would make the waterfront more attractive and enjoyable by drawing more people to the waterfront, round the clock. This in turn would create a safer night time experience and provide shelter on inclement days. Buildings were also expected to add interest and feature ground-floor public uses supporting unspecified activities. The claim that these buildings might comprise the promise of $65 \%$ public space on the waterfront were patently untrue, since Council firmly believed that open spaces were meant to be just that - for out of doors.

Then the following request: MAKE YOUR OWN JUDGEMENTS - THEN MAKE AN INFORMED SUBMISSION, telling the public how to go about doing just that.

- By coming to a waterfront Public Open Day;

- Checking out a scale-model of Council's proposals for the area; and,

- Grabbing a submission form after considering option two.

Ten days were allocated for tendering thoughts on the matter.

\section{Wellington City Council Newsletters}

The most consistent way for Council to get its message across was through newsletters produced in-house, a number of which have appeared over the years under various banners. These were distributed to householders, and made available in public places, as a way of keeping the public up-to-date on current events taking place across the city, as well as development specifically along the harbourfront. Three sequential newsletters are examined to glean Council's version of events leading up to, and including, the Chaffers Park Design Competition: 'Waterfront Newsletter', 'Splash!, and 'On the Waterfront'. A decision was made not to conduct interviews with Council members, in the belief that interviewees might become defensive, or guarded, if asked to respond directly to sensitive issues. Reliance on the contents of newsletters was thought to be more representative, in this instance, of Council's normal communication style with the public.

\section{'Waterfront Newsletter'}

The 'Waterfront Newsletter' first appeared in July of 2000, with the waterfront story being taken up at the point where the WCC has withdrawn its unpopular plan, Variation 17. Rather than dwell on this fiasco a report is given on Council officers who, at this juncture, were busily looking for a new process to move things along on the waterfront. Their goal was to harness the wide interest that existed in this project by speaking with as many individuals and groups as possible. This meant instituting an extensive round of consultation which Council thought would translate into more widespread support. The plan was to develop and implement a new scheme in three distinct stages, Stage One's purpose being to locate agreement on an overall framework for the waterfront, including the values and principles needed to guide it. Stage Two was for developing more detailed plans for each area of the waterfront, while Stage Three's function was to complete the actual public space finally agreed upon. Council hoped to get community endorsement by running a public workshop in early August 2000, as well as a unified vision for the project. It was convinced that in pushing for an urban design framework, which would need endorsement, the necessary guidance would be provided to see a project of this magnitude through to successful completion (Waterfront Newsletter, Issue One, 24 July 
2000). A Waterfront Leadership Group was set up to oversee this endeavour, a body made up of Councillors and individuals chosen from the community, Lindsay Shelton being one of them as President of Waterfront Watch. The plan was to develop, in succession, proposals for each of the waterfront areas, the framework providing not so much details on a building by building or space by space basis, but sufficient information for their context to be understood. Backing up this group was another body, the Waterfront Monitoring Group, whose task was to see that whatever plans were decided upon got implemented. Its members consisted of a mixture of urban designers, architects, landscape architects, planners and other professional experts representing a variety of needs such as transport, cultural, heritage, and the community (Waterfront Newsletter, Issue Two, 30 August, 2000, Issue Three 21 September, 2000).

The Waterfront Leadership Group would hold a number of meetings to nut out the urban design framework, and to confirm the necessary Terms of Reference for the waterfront project as a whole. In order to bring group members up to speed on Council's recent design history, briefs were given covering everything from the 1983 Wellington Civic Trust's Harbour City Competition, 1986 Concept Plan, through to the 1997 and 1998 public space concept plans. This presentation also covered the 2000 concept plan review undertaken following the receipt of submissions on Variation 17. After that presentations were heard from the public whose wants and needs were considered in relation to open spaces, Chaffers Park also getting a mention. In all, some forty groups and individuals were consulted by Council over a three month period in a procedure that was 'based on the principle of a continuous process of engagement' (Waterfront Newsletter, Issue Three, 21 September 2000).

Members of the Leadership Group, being at the forefront of this involvement, were expected to take part in decision-making, attend meetings, comment, offer feedback on proposals, and generally make their views known. By the time their eighth meeting rolled around, plans for the waterfront were shaping up, and once the decision was make to focus attention on open space and public access, things began to fall into place. The plan was harbourfront redevelopment to concentrate on specific themes, such as Maori culture, heritage, nautical matters and trading, with an overall emphasis on the city to sea connection. As things stood, the Chaffers area appeared destined to become a large park with the Herd St Building being retained for apartments, though no final decision had yet been made. A proposal for bringing water into the park was agreed upon, as was the presence of a Chinese Garden, but the real issue was how to make these plans come to fruition. All options were considered though much depended upon:

[...] whether the park was seen as part of the waterfront, or more as a park supporting the surrounding commercial and residential area. [...] If Chaffers was to be made an integral part of waterfront, the group [...] should consider what activities could be there that would encourage people to go to the park.

(Waterfront Newsletter, Issue Four, 19 October 2000) 
During a public meeting, held at Te Papa Museum on the $26^{\text {th }}$ of November, 2000, the Waterfront Leadership Group made a progress report to some 150 people. Details of the four different visions for the Chaffers area were relayed, the first of these being for an urban park; the second, an arts and culture park; the third, a recreation park; while the fourth was for a neighbourhood park. The public was informed that a decision had been made to go for a large, multi-purpose park with an emphasis on recreation because this offered the widest possible range of uses for the community. In provisioning for informal sporting activities, preference would be given to running, walking, and biking activities rather than formal arrangements as found in a more traditional park. Accordingly, the design for this new park had to be such that it attracted visitors and was capable of serving as a drawcard for the area. Bringing water into the site was one way of accomplishing this, that and providing a big, grassed area. A wide promenade would be created along the seaward side of the park as a means of accommodating activity along the entire shoreline, with any new buildings planned for the site being well integrated into the waterfront. They also had to provide services and be capable of opening up onto the promenade, thus ensuring for 'active edges' and no dead spaces along the way (Waterfront Newsletter, Issue Five, 5 December 2000).

The Waterfront Leadership Group had decided that a more independent agency was needed to run and plan the waterfront project, the Lambton Harbour Management Ltd being the best agency to accomplish this so long as it remained flexible and encouraged public participation. Two focus groups were then held, late November 2000, in preparation for a survey of 500 people to be conducted by the research firm ACNielsen. These groups were meant to set out key issues emerging from the Leadership Group meetings, the hottest topic to emerge being the Chaffers Park site. Here, the rub was whether or not new buildings ought to be erected on the site, the height of buildings being the main sticking point, with the public being unsure what Council had in mind. To a lesser degree the proposed Chinese Garden, and Waka House, were also said to be problematic though for reasons unspecified (Waterfront Newsletter, Issue Six, 19 December 2000).

In February of 2001, another progress report from the Waterfront Leadership Group was relayed at a meeting attended by some 70 people, this time to go over finalized decisions. Results from the ACNielson Survey indicated that $72 \%$ of those contacted supported the direction taken by the group for the waterfront's redevelopment. Findings also showed that the proposal set out in the framework for the Chaffers Park site was deemed to be acceptable to about $90 \%$ of respondents. A little more than half wanted the Herd St. building retained, while $46 \%$ were opposed to the introduction of buildings between it and Te Papa Museum in what Council referred to as a transition zone. Rather more than half agreed that a green space was needed, with $85 \%$ saying they thought it should be landscaped in some way. In terms of governance, a great deal of stress had been placed on transparency and openness throughout the process so that the public could see clearly where things were going. But the implications of Council's plans were hard to gauge, particularly where statements were vague:

In line with Resource Management Act and the current District Plan, the [Waterfront Leadership] Group believes that the planning provisions for 
the waterfront should be 'effects based'. This means the planning provisions would not spell out exactly what will happen on the waterfront or how it should be done; rather, they would specify the results or outcomes that should be achieved. [...] As an alternative, a suggestion has been made that the Council uses its powers as owners of the waterfront to protect the framework, rather than immediately incorporating it into the District Plan. This would mean that stage 2 could proceed more quickly, with a District Plan variation done at the end of stage 2 .

(Waterfront Newsletter, Issue Seven, 20 February 2001)

At least the concept of keeping planning and implementation separate entities was easily grasped, the aim here being to have public consultation processes fall under the umbrella of planning, with experts responsible for handling this engagement. Implementation and commercial management were also to be kept apart, as a way of ensuring they remained at arm's length from Wellington City Council. There would be two entities then, one consisting of an independent group of experts, the other of community representatives whose task was to develop design briefs. The Chaffers area was to have its own brief indicating just what sort of amenities were thought good, such as sunlight and wind protection. The designers were charged with setting out the sort of spaces needed to achieve these benefits, something that would have to be done in conjunction with the public whose involvement was built into the process. The completed briefs were then meant to go off to the implementation agency whose business it was to commission the design proper. The final vision for the park would then be bounced between agencies before being signed off, the public having its say throughout these procedures. The current Waterfront Monitoring Group had to oversee all this, making sure sufficient funding was allocated to get the very best possible park, as well as seeing to it that everything complied with the newly developed framework. Although the presence of a Chinese Garden feature was finally approved, being given a position in the transition zone, no firm decision had yet been reached concerning new buildings on the park site. This would have to wait some while longer, since everything seemed to hinge on whether or not new buildings could be seen as contributing positively to the space. Council's idea was to explore this possibility further, this time through design (Waterfront Newsletter, Issue Seven, 20 February 2001).

The new 'Wellington Waterfront Framework' (April 2001) was in the process of being incorporated into the District Plan by way of another variation, a move intended to give statutory weight to Wellington City Council's policy for the waterfront. The public was given an opportunity to make submissions on this framework through the Resource Management Act's statutory process. Again, the drift was hard to follow for outsiders:

New buildings and significant alterations to existing buildings would be a Discretionary Activity (Unrestricted) and would require a notified resource consent. This requirement would be in the form of a rule. At a future date this rule could be amended when a further variation is introduced to incorporate decisions made during stage two of the waterfront planning process (Waterfront Newsletter, Issue Eight, 15 March 2001). 
With the adoption of the Waterfront Leaderships Group's report, in early April of 2001, the waterfront policy was set, allowing for Stage 2 of the project to go ahead under the supervision of the new Waterfront Development Sub-Committee. Although paid members for this committee had not yet been appointed, nominations were expected to come from the community with some design representatives likely to figure. The plan was for this body to meet on a fortnightly basis at first, then possibly monthly after that. In enshrining the waterfront framework in the District Plan, also known as Variation 22, the aim was to hurry along procedures which were already heading for hearings towards the end of December 2001. The revised plan could only be integrated once due notification of the public had been given and the necessary period of receiving submissions and cross-submissions allowed for. Once this was sorted out, the Central Area proposed along the waterfront would get underway. This was done to simplify matters and circumvent challenges that might attempt to block Council's plans for incorporating the Waterfront Framework into the Plan - all of which indicated that a great deal of care was being taken in formulating the latest variation (Waterfront Newsletter, Issue Nine, 7 May 2001).

Concerns around governance structures had yet to be resolved with the establishment of two governance entities, those of planning and implementing, still involved risks. If resourcing was insufficient, or there was a lack of goodwill on the part of the public, then problems were sure to arise, meaning that opposition had to be factored into the overall plan if a successful outcome was ever to be reached. But the mechanisms of this were complex. The Waterfront Development Sub-Committee (WDSC) reported to the WCC's Strategic Committee on actions taken in developing a plan and prioritising work. The WDSC already had a lot on its plate, what with engaging the public, working up design briefs, signing off projects work and approving any plan variations during implementation phases. For its part, the Lambton Harbour Management Ltd (LHML) had to report back on business plans for the waterfront, provide input to the project and make revisions to plans. In addition to this, daily operation of the waterfront area had to be managed which included running events, doing the clean up after them, as well as maintenance and security for the area. The WDSC also had to be advised on budgeting, costs, and development phasing, amongst other matters. The LMHL's role was to market the waterfront sites and get a good return on them for Council, while also acting as the contact for those interested in private development projects. It helped to negotiate these spaces, in addition to managing their design and building (Waterfront Newsletter, Issue Ten, 21 June 2001).

As part of the Stage Two process, the WDSC had to complete a Development Plan for the waterfront as a means of implementing the Waterfront Framework. The plan for this would come directly from concepts set out in the Framework, whose principles were being covered by way of public involvement. Other priorities, such as working out different projects, financial plans, as well as performance briefs also needed to be taken into consideration. Issues relating to the generation of income, the lessening of impact on rates, timing on commercial development to meet market conditions, and the restoration of heritage buildings were important factors that required careful thought. Keeping the public on board with these plans was no small feat, it being the Waterfront Leadership 
Group's business to go out and seek input and feedback on pertinent issues. Provisions for various communications tools were made available to the group, including open meetings, workshops, newsletters, e-mail discussion groups, web sites, reports in Council newspapers, as well as advertisements (Waterfront Newsletter, Issue Eleven, 20 August 2001).

While this was transpiring a slight hiccup developed in the form of an impending hearing in the Environment Court, set for late November of 2001, which related to the shifting of the Free Ambulance Building. Nothing could be done about it until resource consent was granted, so the Court's decision was being awaited to see if it could be moved further along the waterfront to make way for new buildings. Waterfront Watch was trying to block this from transpiring, drawing this reaction from Council:

Regardless of whether a resource consent is granted to move the building, the WCC will have the final say because it owns the building and the Council has asked for the subcommittee's views on moving the building.

(Waterfront Newsletter, Issue Twelve, 21 September 2001)

This blip isn't dwelt upon, the newsletter moving on instead to the issue of submissions that were about to be received by Council, in late October 2001, concerning the whole of the waterfront. Comments from these submissions called for the Chaffers site to be retained as an open space with new buildings being allowed only for servicing the park itself (Waterfront Newsletter, Issue Thirteen, 29 October 2001). In mid-December of the same year, a design competition for Chaffers Park was announced, Council being of the opinion that people wanted something to happen at Chaffers and were anxious that what went there was the best possible thing for the city (Waterfront Newsletter, Issue Fourteen, 19 December 2001). Wellingtonians would have a chance to help design the park with the assistance of the Waterfront Development Subcommittee, who would be in charge of setting up a programme for transforming the Chaffers site.

The intention was to hold an 'ideas day' as part of a two-staged competition process that would be open to all - at no cost to participants - which ensured public involvement. But time was of the essence, meaning that the event had to be run quickly and without delays. The programme was launched in late February and registrations accepted for the first stage of the competition in March of 2002. The ideas day was to be held in early March with people invited to sketch, write, or voice their concepts for the new Chaffers Park. These would then be passed on to entrants as part of their brief and there would move on to the second stage of the competition. Those short-listed would be asked to develop their concepts in greater detail and a winner selected in July of 2002, allowing for work to begin on the site sometime in 2003. Although the timeframe for this competition was very ambitious, it was nevertheless in accordance with plans already set in the Waterfront Development Plan (Waterfront Newsletter, Issue Fourteen, 19 December 2001). 
In late January of 2002, the design brief was finalized and the overall programme approved by the Waterfront Development Subcommittee. A month later, a presentation of the project was made to the public and the proposed process set out, the upshot being that by the beginning of March those keen on registering interest in the competition were in a position to put their names forward. In the midst of this, an interactive ideas workshop was held whose purpose was to contribute to an ideas attachment going into the design brief for final sign-off in mid-March. The competition was scheduled to open on the $21^{\text {st }}$ of March, with the closing date for Stage 1 elapsing on the $19^{\text {th }}$ of April. By the $22^{\text {nd }}$, the stage one designs had been set up for exhibition, with all entries anonymous. The public was given a two week period to comment on designs, with the judging scheduled to take place on the $20^{\text {th }}$ of May. Winners would be announced in that same week and sent away to do more detailed proposals which would then have to be ready by the $1^{\text {st }}$ of July, one month later. Stage 2 of the competition would then be closed.

The next two weeks, to mid-July 2002, would be taken up with designers presenting their park ideas to the Waterfront Development Subcommittee, culminating in the actual judging night to be held on July 15th. Following the announcement of the winning scheme, two days later, the public would also be given a chance to give feedback on the winning design, after which the selected winner would be officially commissioned by the Lambton Harbour Management Ltd. A shop front for the waterfront redevelopment was being set up where designs could be displayed, giving Council a venue for showing the finalized design which was likely to have to undergo further amendment. This display area, which was on the waterfront itself, offered 'a good level of interaction with the public', consisting of a venue where interested parties could see what Council was proposing and also drop off any comments they might have. Passers would be able to scrutinise plans and models of the area, as well as pick up information made available by Council. The newsletter then went on to report that the Lambton Harbour Management Limited had decided to withdraw its Environment Court application for the shift of the Free Ambulance Building, a move Council had little choice but to support given Waterfront Watch's victory (Waterfront Newsletter, Issue Fourteen, 19 December 2001).

The plan was working according to schedule, with the turnout for the Chaffers ideas day, on Saturday, 9 March 2002, being very good with over two hundred showing up at the Overseas Passenger Terminal to share their thoughts. Architecture students were there to help people sketch out their ideas with all ages giving it a go, leaving the chair of the WDSC, David Kernohan, very pleased with proceedings. 'It was wonderful', he said, 'to see so many people taking part.' (Waterfront Newsletter, Issue Fifteen, 3 April 2002). Every conceivable type of idea for a park had been proposed, with copies of this material being distributed to the competition entrants as part of their information packs. They could develop some of these ideas further or go with their own vision, as it suited. Information about the competition, including plans and photos of the site, was made available on Council's website, with around 250 people entering the competition from New Zealand and further abroad. The WDSC approved the evaluation process and assessment criteria for the competition, with judging of both stages to be carried out by the same body with assistance from its Technical Advisory Group. This independent panel, made up of professional advisors, had the task of carefully scrutinising each entry 
in order to make sure it was feasible and fitted within budget constraints (Waterfront Newsletter, Issue Fifteen, 3 April 2002). An exhibition of 129 entries was held at the Herd Street Building, from which 17 were short-listed for further consideration by the Waterfront Subcommittee. At Stage 2 of the competition, public feedback was considered as well as recommendations coming out of the two advisory panels, resulting in the whittling down of entrants to five finalists.

Benoit Vignes and Ariane Smythe, international entrants and landscape architecture students hailing from Versailles, France;

Chris Yandle and Peter Rough of Peter Rough Landscape Architects of Christchurch;

Megan Wraight Landscape Architects, AthfieldArchitects, Stantiall's Studio of Wellingon, the New South Wales Dept of Public Works and Services Landscape Environment and Urban Design Unit, Australia;

John Gray, Michael Sorkin, Tim Nees, and Catherine Alington of Wellington;

Rachel Hughes with Beca Carter Hollings and Ferner [the complete team being comprised of architects Novak \& Middleton, landscape architects

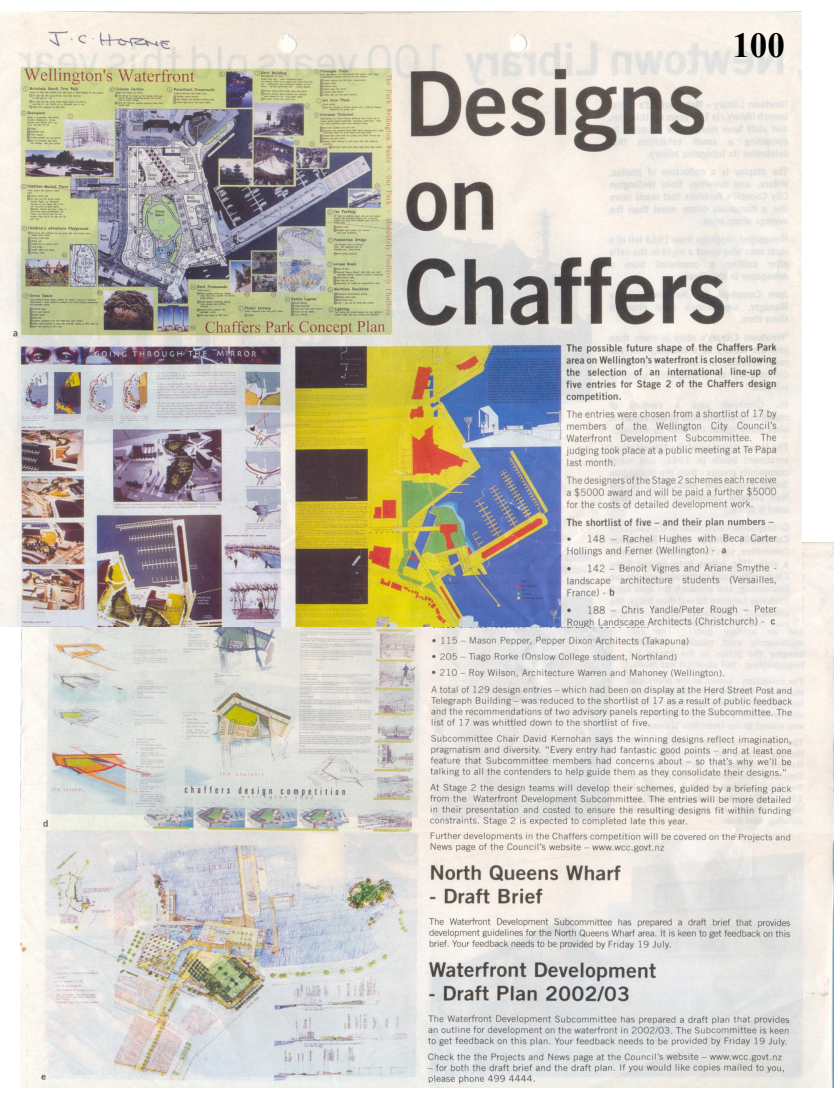

Earthwork, artists Robyn Kahukiwa, Chris Booth, Noeline Walker, skatepark designer Campbell Johnson, playground specialists Galloway International, and model maker Florian Franzmayer].

David Kernohan, Chair of the Subcommittee, was delighted with the designs and commented positively on the diversity, imagination and pragmatism displayed in them. He noted that 'every entry had fantastic good points - and at least one feature that Subcommittee members had concerns about - so that's why we'll be talking to all the contenders to help guide them as they consolidate their designs.'(Waterfront Newsletter, Issue Sixteen, 17 June 2002). As planned, the finalists' designs were displayed in Shed 6 on the waterfront, where the public got a good look at the schemes and were able to write their comments on forms provided, with Council asking people to fill out only one each to ensure a fair representation. In addition to public feedback, public submissions on the proposals were received, as well as findings from a formal survey. 
As part of this process, a video of all five finalists was produced in which each of the finalists' designs were shown using camera pans over their three-dimensional models 39. On October $7^{\text {th }}$ of 2002 , the finalists presented their entries at an evening meeting attended by some 300 people, marking the end of this newsletter's reports on the competition process proper (Waterfront Newsletter, Issue Seventeen, 21 August 2002, Issue Eighteen, 23 October 2002).

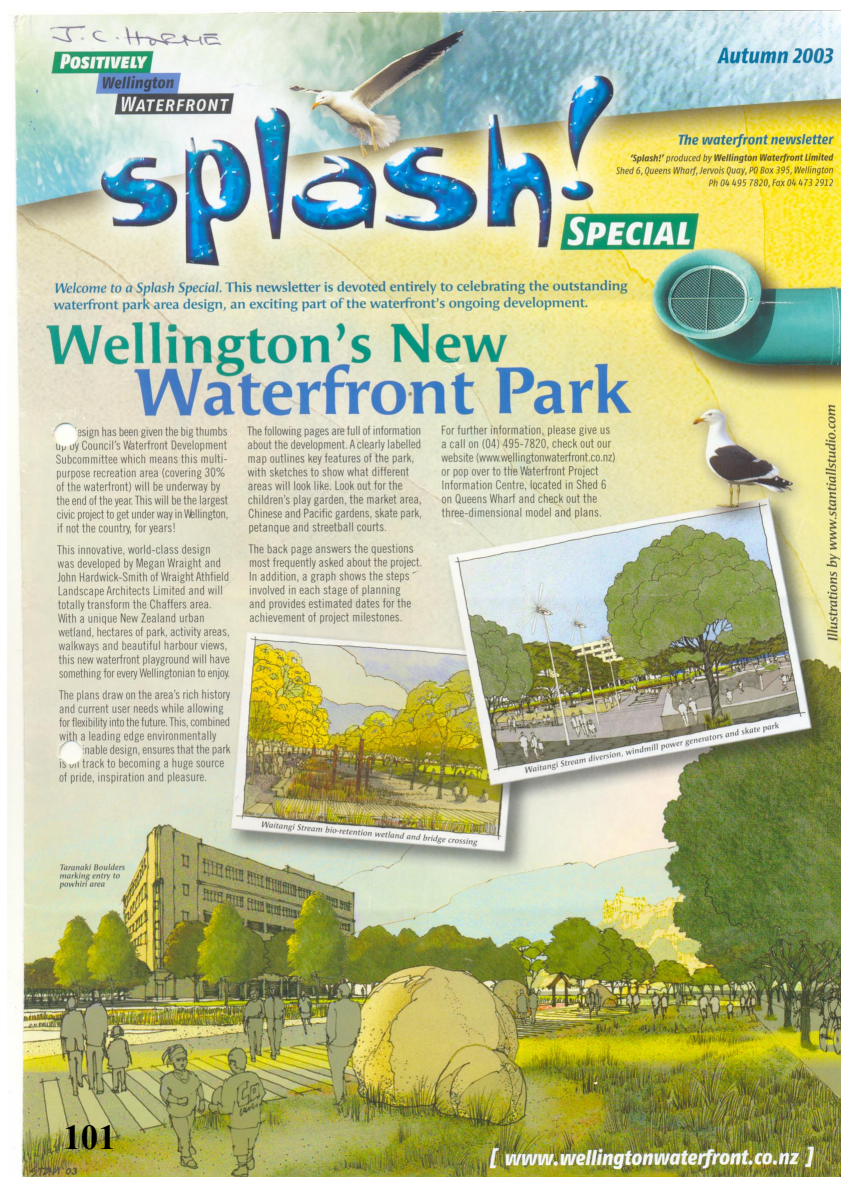

\section{'Splash! \\ The waterfront newsletter'}

Published by Wellington City Council Company through its Positively Wellington Waterfront/ Wellington Waterfront Ltd, 'Splash' was a quarterly newsletter with an altogether different feel from the 'Waterfront Newswletter'. 'Splash Specials', like the one shown alongside, provided information on projects to do with waterfront redevelopment issues, such as the new harbourside park. The Autumn, 2003 issue was devoted to celebrating the new and outstanding waterfront park designed by Megan Wraight Landscape Architects and John Hardwick-Smith of Athfield Architects, winners of the Chaffers Park Design Competition. This newsletter focussed on informing the public of how projects were developing, particularly the Chaffers site which was beginning its longawaited transformation. Sketches of

the proposed park were provided along with plans, giving the reader a good idea of what the final outcome might look like in years to come. The name Chaffers was no longer being used in conjunction with the site, signalling an impending name change for the park. In addition, the newsletter devoted a page to answering frequently asked questions concerning the new park, such as who was paying for the new park; how much would it cost; what its design reflected culturally and historically. It even tackled the issue of whether, or not, the proposed wetlands posed a danger to park visitors. In terms of what the park would be called once finished, the Tenths Trust had recommended it be renamed Waitangi Park in keeping with the significance of the area's Waitangi Lagoon and Stream. This rebranding of the site brought to an end the site's long association with the ill-fated William Main Chaffers, Master RN, a founder of Wellington, and its first harbour master (Edwards 1989).

\footnotetext{
${ }^{39}$ Wellington City Council [video] Chaffers Park Design Competition, 2003.
} 


\section{'On the Waterfront'}

The first issue of this monthly newsletter appeared in May, 2004. Its purpose was to show the public what made Wellington's waterfront unique, also to inform them of new developments being proposed that would further enhance the area's value and beauty. Notice was given that construction on Waitangi Park was about to begin, with tenders going out to interested contractors. In June, work was reported as having commenced on the waterfront promenade, while in the July issue a picture is shown of the Mayor, Kerry Prendergast, turning the first sod on the site in the company of Dr Ngatata Love, an elder of the Wellington Tenth's Trust. In the following newsletters, available on-line at this point, the park's transformation is depicted photographically, giving a clear indication of the progress that was being made at every step of construction. In the tenth issue, the problem of soil contamination at the site is touched upon briefly, the lead levels having exceeded the Greater Wellington Regional Council's resource consent for disposal, a fact discovered through commissioned tests. With its eighteenth issue, published in March 2006, announcement is made that the barriers had come down around the park in preparation for the New Zealand International Festival of the Arts, the first special event to be held there. Although Waitangi Park was not yet fully completed, an exhibition entitled 'Earth From Above' was staged with the park's precincts, a colourful event attended by scores of curious Wellingtonians.

\section{The Design Expert's Perspective}

In spite of the fact that Council's practices, in addition to those of Wellington Waterfront, were roundly criticised by lobby groups, the public, and even Audit New Zealand there were still numerous supporters prepared to give the City a big thumbs up, with professionals fully endorsing the processes used to select Waitangi Park's design ${ }^{40}$. For instance:

The New Zealand Institute of Architects recently announced Waitangi Park was among this year's New Zealand Award recipients. The Awards judging panel described the park as "an integral piece of Wellington's waterfront landscape that has been embraced by the whole city". The panel added that the park "is a dense layering of rich ideas; historical, cultural, ecological, ESD [Environmentally Sustainable Design] features and mixed recreational spaces for a diverse range of users". With tremendous pride and great delight, Athfield Architects ltd and Wraight and Associates ltd accepted a Supreme Award for the design of Waitangi Park from the New Zealand Institute of Architects (NZIA).

(On the Waterfront, Issue 29, April 2007)

The park also received a Mention at the prestigious Torsanlorenzo International Landscape Architecture Competition, the judging panel in this instance consisting of some of the world's top landscape architects. They noted that Waitangi Park was receiving this award in the urban green spaces category because it consisted of a public park where urban and ecological values had been used to create a distinct sense of place. Further, that this effect had been achieved through judicious choice, and sensitive planting design, of indigenous vegetation (On the Waterfront, Issue 29, April 2007).

${ }^{40}$ Johns, Ralph, 'A shore thing' in Landscape New Zealand, August 2006, pp.6-8. 
Not to be outdone, the New Zealand Institute of Landscape Architects decided to grant Waitangi Park its Award of Excellence for Sustainability ${ }^{41}$, making it clear for all to see that the park's creators did indeed have 'The Wraight Stuff' (On the Waterfront, Issue 15, 2005). Thanks to the efforts of architect John Hardwick-Smith of Athfield Architects, and Landscape architect Megan Wraight of Wraight and Associates Ltd, what had once been a sad and neglected site was finally undergoing a remarkable transformation for the better. In the magazine 'Forest \& Bird'42, Wraight was credited with being the architect of nature's return to Wellington's shoreline, and

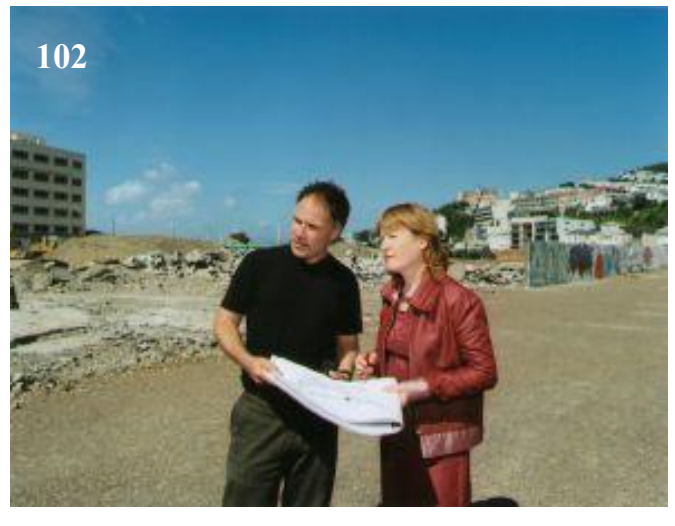
when asked to define the approach she used, Wraight insisted that the real genesis of the park idea belonged to Wellington City Council. Its 1997 Waterfront Masterplan set out to strip away the changes to Wellington's shoreline, thereby revealing its original ecology. Rather than create a nature reserve, Wraight had sought to combine the idea of a cultural park with that of a 'remnant ecology', in an altogether new park model. Of the criticism leveled at Council's processes and the principles underpinning the Chaffers Park Design Competition, Wraight had only this to say:

The council never intended to go solely with the results of the public survey the Framework was developed to provide a rigorous assessment of proposals for the waterfront. But the public perceived that once asked, they would be listened to [...] [But] the development of the waterfront was never going to be decided by public opinion. Otherwise, the Waterfront Framework and the technical advisory groups would be redundant.

(Architecture New Zealand, Jan/Feb 2003, No.1, p.72)

Nor was Council remiss in its duty to the public, supplying reports, surveys, charts, and other statistical facts justifying their evaluation and selection of Scheme A as overall winner of the Chaffers Park Design Competition ${ }^{43}$.

\footnotetext{
41 'Waitangi Park: Wellington's newest urban playground', Landscape New Zealand, Issue 2, 2006.

42 Park, Geoff, 'The remnant ecologies of Waitangi Park' in Forest \& Bird, August 2007, pp.36-37.

43 Wellington City Council

Wellington Waterfront Development Subcommittee

Assessment of Chaffers Design Competition Entries, 20 May 2002.

Results of Public Consultation on Chaffers Design Competition Finalists, Report 3,

25 November 2002.

Chaffers Park Design Competition winner selection, Report 4, 25 November 2002.

Chaffers Design Competition, a report prepared by ACNielsen for WCC, November 2002.

Wellington Waterfront Development Subcommittee, Technical Advisory Group

Review of Chaffers Park Competition, Stage 2, 18 November 2002.

Review of Waitangi Park, Report 6, 22 August 2007.

Waitangi Park Design Quality Audit, 14 June 2007.

Evaluation of Waitangi Park - a Qualitative Study, April 2007.

Wellington Waterfront General Users Survey, UMR Research, April 2008.
} 


\title{
Acknowledging Anomalies
}

Sometimes anomalies are acknowledged by the media, while at other times they are ignored, or curtailed drastically, depending on the response garnered from the public, advertiser, or powerful detractors. If a newspaper senses that its readership may be tiring of an issue, or if outside pressure is brought to bear, then a story can be made to disappear and reappear again, according to circumstances. In taking up the waterfront debate from the perspective of local Wellington newspapers, a rather serendipitous account emerges over the 13 year period leading up to, and beyond, the Chafers Park Design Competition.

\section{'Wanted: a vision'}

City Voice, 14 March 1996.

Tough questions were asked: 'The Waterfront: can we trust Lambton Harbour Management?'

City Voice, 18 April 1996.

Its point being:

\author{
"Waterfront 'for people, not profits"” \\ City Voice, 23 May 1996.
}

That a problem existed:

'Lambton Harbour mismanagement'

City Voice, 8 August 1996.

\author{
Which needed addressing: 'Lambton Harbour twists \\ consultation process' \\ City Voice, 10 July 1997.
}

\section{Indicating: 'Campaign for bigger Chaffers Park' \\ City Voice, 24 July 1997.}


Noting issues from the lobbyist's perspective:

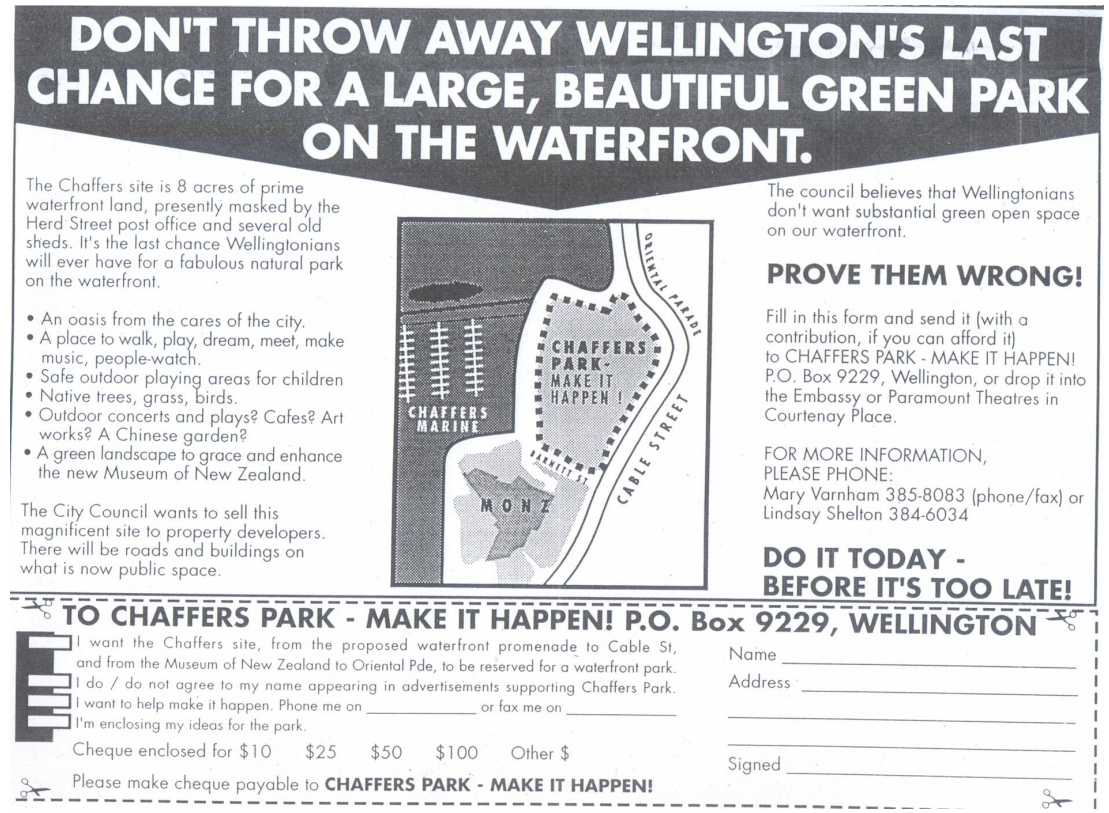

City Voice, 7 Aug 1997.

While showing that numbers did count: $\quad$ 'Thousands back park,

City Voice, 25 September 1997.

Bemoaning the fact that:

'Consultation axed'

City Voice, 9 October 1997.

Moreover, quick to point out that:

\section{'Wall of buildings' opposed}

City Voice, 30 October 1997.

That augured a:

\section{'Dysfunctional city?'}

City Voice, 20 November 1997.

Reminding Wellingtonians that it was:

'Our Waterfront'
City Voice, 27 November 1997.

And urging them to:

\section{'Claim the city'}

City Voice, 29 January 1998. 
Stirring things up:

\section{'Chaos reigns again on waterfront' \\ City Voice, 12 March 1998.}

Fanning the flames:

\section{"Candidates claim 'lies' over} Chaffers Park"

City Voice, 24 September 1998.

Sure of one thing only:

'Council in a mess'

City Voice, 1 April 1999.

Proposing solutions:

'Waterfront slowdown urged'

City Voice, 29 April 1999.

Prognosticating:

As:

'WAR ON THE WATERFRONT'

Latest scheme reopens divisions

City Voice, 19 January 2000.

Outcome:

'Tidal wave against waterfront plans'

City Voice, 20 January 2000.

Evaluation:

'Waterfront farce'

City Voice, 20 January 2000.

Adding a reminder:

"No compromise on harbour"

City Voice, 27 January 2000.

That a revolution was ahead:

\section{'Aux armes, citoyens!'}

City Voice, 10 February 2000.

Calling for the foe's head:

\section{'Blumsky to block democracy' \\ City Voice, 29 June 2000.}

Acting the scourge:
'Democracy poisoned'
City Voice, 13 July 2000. 
Never satisfied with the status quo, the City Voice always sought to redress what it perceived as injustices, and inequitable practices, coming out of Wellington City Council.

\section{The Wellington dailies: The Dominion, The Evening Post, The Dominion Post}

With the abrupt demise of the City Voice in 2000, lobby groups lost a significant platform for raising their concerns. This meant having to rely on Wellington's two daily newspapers instead, whose support was less guaranteed. The Wellington Civic Trust and Waterfront Watch did publish newsletters of their own, which were circulated to members, but wider coverage was always better in bringing to light anomalies and battling through disputes with Council. The Evening Post and The Dominion covered events but in a less dramatic fashion than the City Voice, employing more cautious language and an approach to reporting the conflict that appeared to favour neither one side nor the other. With the amalgamation of The Evening Post and The Dominion, into The Dominion Post, coverage of waterfront events was halved, which meant that even fewer versions of the story were available to the public for comparison purposes. The tone adopted in coverage is factual and to the point, with fewer dramatics:

\section{'Council to discuss waterfront'}

The Evening Post, 20 May 1996.

Playing down drama:

Pressing the point quietly:

Sighing over problems:

Stating the obvious:

Offering a solution:

Laying out the agenda:

\section{'Time to pause - Blumsky'}

The Evening Post, 20 May 1996.

\author{
'The common theme: put people first' \\ The Evening Post, 28 May 1996.
}

\section{'Waterfront dilemmas'}

The Dominion, 24 July 1996.

\section{'Attack on Lambton planning'}

The Dominion, 13 May 1997.

\section{'Buildings not parks urged for waterfront'}

The Dominion, 14 August 1997.

\section{'Chaffers site the key issue at council meeting'}

The Dominion, 15 August 1997. 
Informing generally:

\section{'Guidelines set for Chaffers'}

The Dominion, 16 August 1997.

Reporting progress:

\section{'Big city park at Chaffers a step closer'}

The Evening Post, 3 September 1997.

Providing good advice:

\section{'New council must have eye on future'}

The Evening Post, 12 November 1998.

Asking for more:

\section{'Details please'}

The Dominion, 22 January 2000.

Noting disappointments:

'Mayor let us down'

The Dominion, 24 January 2000.

Pressing the issue a little:

\section{'Objections run hot over waterfront'}

The Evening Post, 29 January 2000.

Reminding Council:

\section{'Foreshore is public space'}

The Dominion, 22 January 2000.

Leaning on it: 'Hundreds rally against harbour plan'

The Evening Post, 28 January 2000.

Taking one side, for a time:

\section{'Call to stand firm on waterfront'}

The Evening Post, 29 January 2000.

Showing public's indignation:

\section{'Up in arms'}

The Evening Post, 29 January 2000.

Then reporting on Council's response:

'Mayor backs off seafront plan'

Sunday Star Times, 30 January 2000. 
Bringing in other voices:

\section{'Councillors ready for waterfront row'}

The Evening Post, 31 January 2000.

Setting the stage:

\section{'Full house expected in fight against Variation 17'}

The Evening Post, 1 February 2000.

Being there when the sleeping giant awakes:

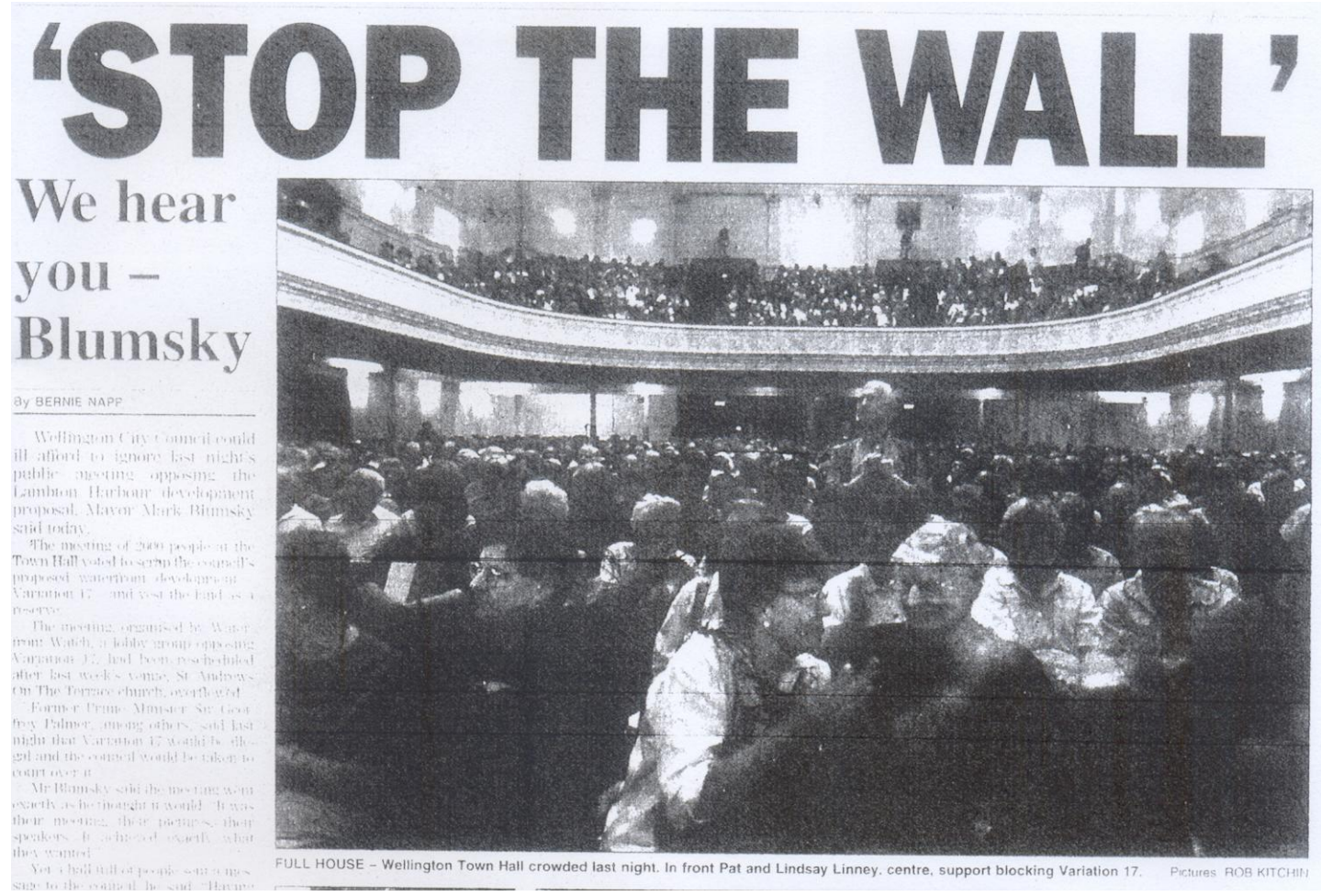

The Evening Post, 2 February 2000.

Teetering along with everyone else:

\section{'Waterfront battle close to the edge'}

The Dominion, 2 February 2000.

Never over-embellishing:

'Waterfront protest packs town hall' 
Giving experts the occasional say:

\section{'Smokescreen on the waterfront'}

The Evening Post, 5 February 2000.

Finally splashing out:

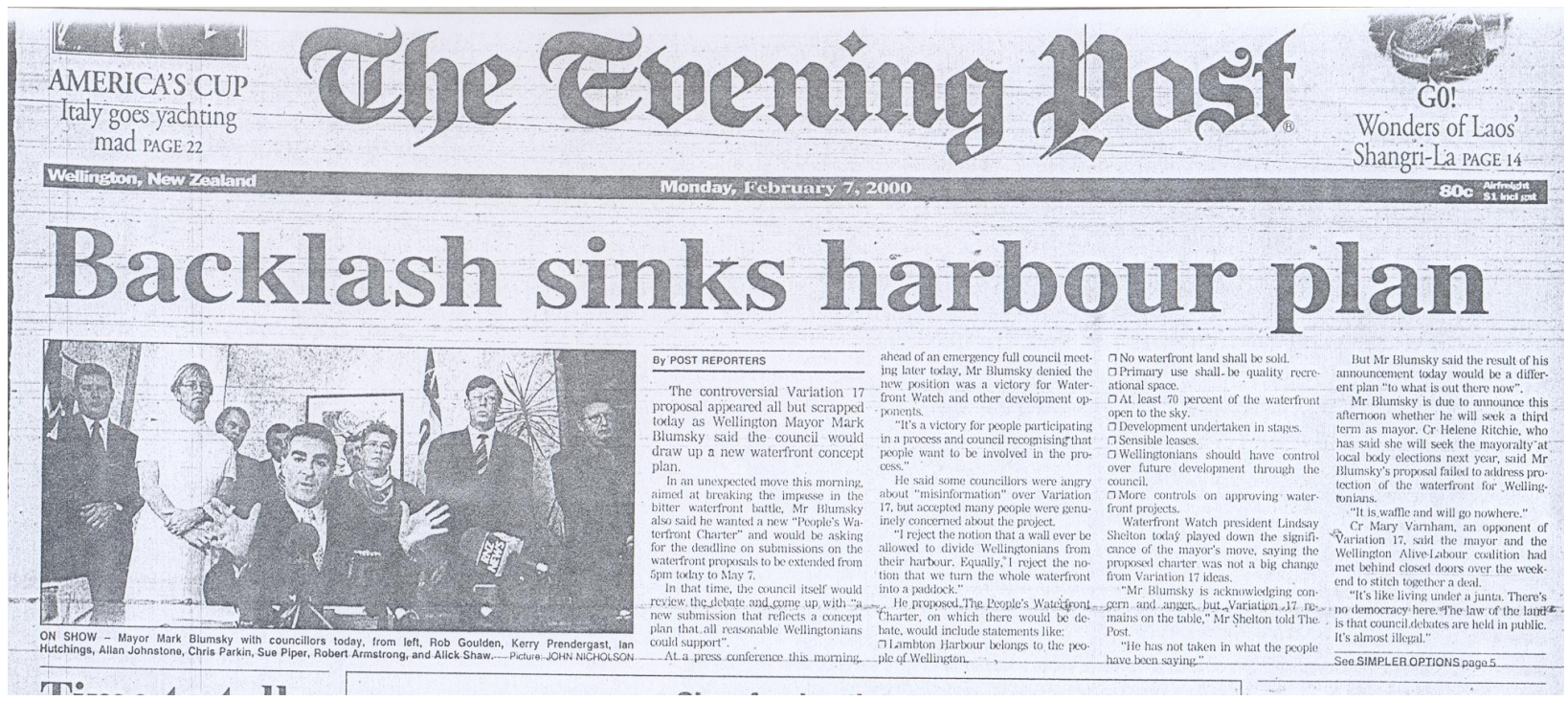

The Evening Post, 7 February, 2000.

To show that:

\section{"Council's 'middle way' is meaningless, say opponents"}

The Evening Post, 8 February 2000.

And no end to:

\section{'Wrestling on the waterfront'}

The Dominion, 15 February 2000.

Until: $\quad$ 'Sombre council pulls Variation 17 plug'

The Evening Post, 14 April 2000. 
Welcoming uplifting news:

\section{Design contest for Chaffers}

\section{By DEAN BEDFORD} Waterfront reporter

A public design competition is to be held to get ideas on how to devel op Chaffers Park.

The park is the first big project for Wellington City Council's waterfront development subcommittee.

The subcommittee is trying to

move cautiously to keep public opinion on side after widespread op position to waterfront plans las year. However, the competition will

be to specifications to be drawn up by the subcommittee.

It hasn't yet been decided wheth r that brief will allow for buildinos at Chaffers Park. Much of last year's backlash was a reaction to proposals to build tall buildings along the waterfront.

Opponents were worried that buildings would cut off sea views and access to the waterfront. But others thought buildings provided greater security and more life to the waterfront in the evenings than open green space.

A final plan on how the compet tion would work would go to a subcommittee meeting this week. But it was likely the council would adyert ise for groups to register their inter- est in a design competition. The de signs would be publicly displayed, three would be further developed with the help of professional design ers and the council would pick a winner some time in the middle of next year.

The council wanted to promote public participation in the project and have designs that were profes sionally produced.

Design plans were drawn up in 1997 with some retaining the Herd St former Post Office building and some not.

SeO LHM SCRAPS page 12
The Evening Post, 26 November 2001.

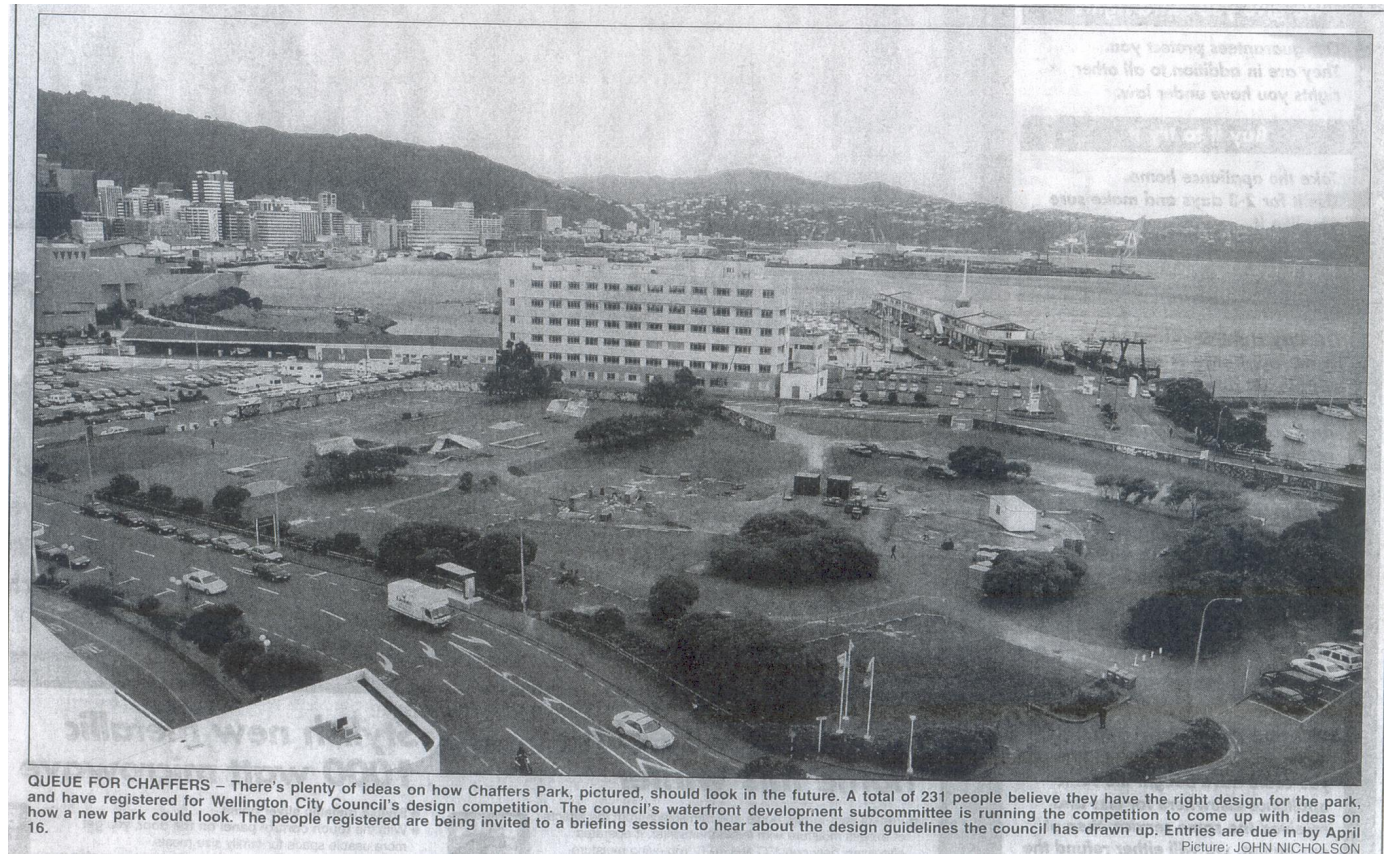

'Queue for Chaffers - There's plenty of ideas on how Chaffers Park, pictured, should look in the future. A total of 231 people believe they have the right design for the park, and have registered for Wellington city Council's design competition. The council's waterfront development subcommittee is running the competition to come up with ideas on how a new park could look. The people registered are being invited to a briefing session to hear about the design guidelines the council has drawn up. Entries are due in by April 16.'

Rallying support for this event:

\section{'Chaffers' future inspires designers'}

The Evening Post, 19 April 2002. 
Then doubling back:

\section{'Is nothing safe from the bulldozer mentality?' \\ The Evening Post, 11 May, 2002.}

Laying down the options:

\section{'PARK DESIGN PLANS AT A GLANCE'}

Five design proposals which have been shortlisted for

Chafers Park. The winner will be chosen next month.

The Dominion Post, 9 October 2002.

Spotting winners:

'Park design favourite chosen'

The Dominion Post, 16 October 2002.

Nudging in one direction:

'Call to keep Chaffers simple'

The Dominion Post, 8 November 2002.

Backing the dark horse:

\section{'Park backers deny dirty tricks'}

The Dominion Post, 21, November 2002.

Amidst pleas:

"Chaffers debate: "Listen to the people",

The Dominion Post, 23 November 2002.

Seeing the storm clouds:

'Crunch time for Chaffers Park site'

The Dominion Post, 25 November 2002.

Unveiling:

'Experts' plan gets Chaffers nod'

The Dominion Post, 26 November 2002.

Highlighting consternation:

'Waterfront Watch to meet over Chaffers decision'

The Dominion Post, 27 November 2002.

Giving Lindsay Shelton the floor:

\section{'What people want and why they don't get it' The Dominion Post, 20 January 2003.}

Digging in for another battle:

\section{'Park building plan faces fight' \\ The Dominion Post, 5 May 2003.}


Moving things along:

\section{'Chaffers park area approved'}

The Dominion Post, 13 May 2003.

Rooting for:

\section{'Waterfront Warriors'}

The Dominion Post, 22 July 2003.

While also giving Mayor a say:

\section{'Let's get on with it'}

The Dominion Post, 23 July 2003.

Having misgivings:

'Who can you trust with the waterfront?

The Dominion Post, 26 July 2003.

Providing the obituary:

\section{'Farewell for Chaffers Park'}

The Dominion Post, 23 October 2003.

Lobbing salvos:

'Council under fire again'
The Dominion Post, 10 May 2004.

Getting a dig in at lobbyists:

\section{'Waterfront Watch 'spoilers' - Wilde \\ The Dominion Post, 30 April 2004.}

While giving more heartening news:

$$
\begin{aligned}
& \text { 'Park project taking shape' } \\
& \text { The Dominion Post, } 16 \text { March } 2005 .
\end{aligned}
$$

As speculation continues over:

\section{'Waterfront's tarnished jewel'}

The Dominion Post, 10 December 2005.

Seeing to the scuttling of another unpopular vision: 


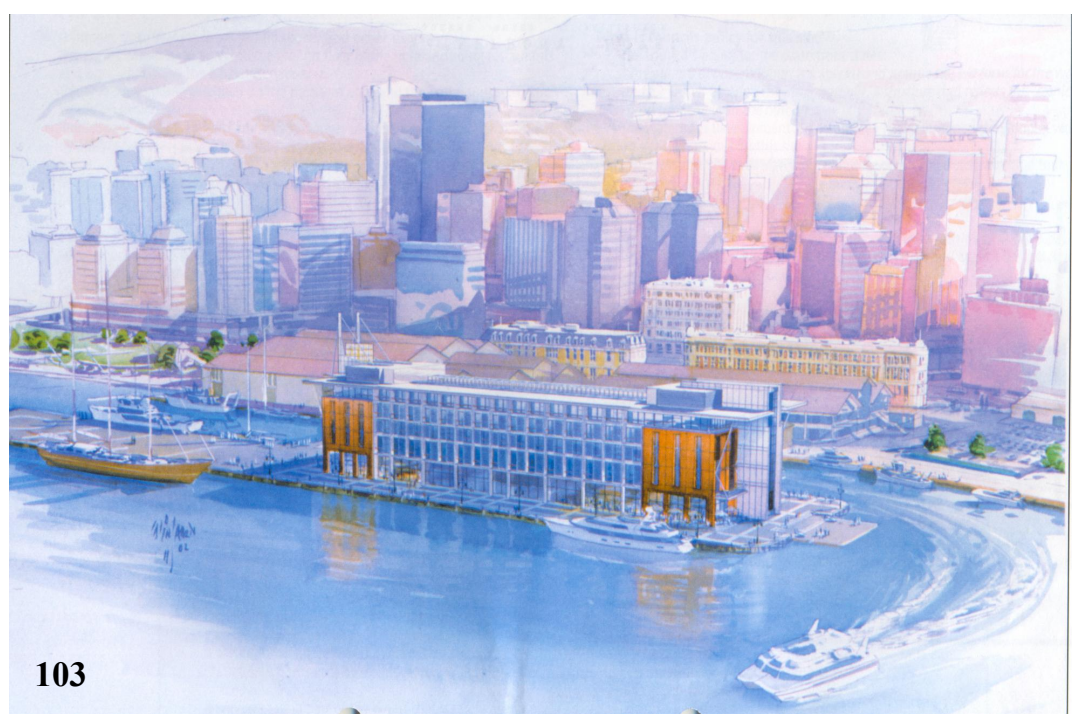

\section{'End of the line' for Hilton on waterfront'}

The Dominion Post, 10 April 2008.

Warning of other possible setbacks to come:

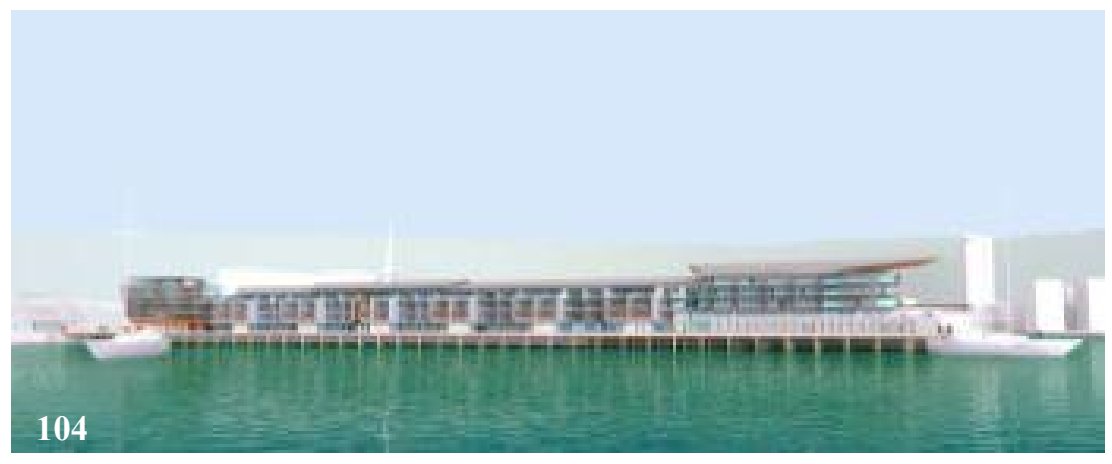

Proposed Overseas Passenger Terminal.

\section{'Waterfront appeal'}

A $\$ 100$ million redevelopment of Wellington's Overseas Passenger Terminal is on hold after Waterfront Watch lodged an appeal to the Environment Court. The appeal could delay construction of the proposed 90-unit apartment and retail development by 12 to 18 months. Waterfront Watch president Pauline Swann said Wellington City Council and its wholly owned company Wellington Waterfront Ltd failed to consult the public over the site's future.

The Dominion Post, 27 May 2008. 
Lending a hand:

\title{
'Council wants your opinion'
}

The Dominion Post, 1 May 2008.

As the next conflict unfolds:

\author{
'Cloud over waterfront plans \\ Council feels pinch after hotel vetoed' \\ The Dominion Post, 17 June 2008.
}

Querying:

\section{'Why the council secrecy?'}

The Dominion Post, 28 August 2008.

Revealing the next move:

\section{'Nats ready controversial RMA planning shakeup'}

'The government is poised to make radical changes to the Resource Management Act, drastically raising fines, cutting the time spent considering major projects and limiting some appeal rights. [...] The bill would be "pretty aggressive" in dealing with vexatious and frivolous objections and would crack down on companies that used the planning process to try to frustrate commercial rivals [...] There will be some controversy around our attempt to find a better balance between the rights of citizens to participate in the planning process and the time it's taking [...]'

Sunday Star Times, 1 February 2009.

While signaling concern:

\section{"RMA changes may go "too far"” HOW CHANGES AFFECT YOU \\ The Dominion Post, 4 February 2009.}

Remarking on sweeping changes to organizational structure that might have the effect of silencing legitimate public input into decision-making, possibly putting paid to much of the work undertaken by lobby groups such as Waterfront Watch. 


\section{Second Evaluation}

In Wellington City Council's version, the story unfolds in a homogeneous and seamless manner, betraying none of the controversy or division associated with Wellington's waterfront redevelopment. No contradictions, or doubts, are allowed to surface in its retelling that could disrupt the easy flow of the narrative which gives the erroneous impression that Waitangi Park's creation went off without any hitches. Processes, procedures, and organisation are shown to have proceeded in an orderly and efficacious manner, with facts being presented throughout to support this rendering of events.

Council's poor relations with lobby groups 'Waterfront Watch' and 'Chaffers Park Make - It Happen' get no mention in the newsletter coverage which gives the impression that lobbyists played no part whatsoever in the creation of Waitangi Park. This deliberate omission gives some indication of Council's capacity for writing out versions of history that conflict with its own, also its propensity for leaving out reference to events that show Council's actions in an unfavourable light. However, in failing to acknowledge the involvement and presence of lobbyists, an injustice takes place because these groups are known to have been instrumental in safeguarding the Chaffers area from privatization. Similarly, in sidestepping the issue of its original reluctance to take up the park idea in lieu of a housing estate and commercial development the uninformed reader might well be led to believe that Council was the sole instigator and champion of an open, green space on the site, this being far from the case.

Nor does the issue of conflicts of interest arise, possibly because none were thought to exist, or because they were an in-house concern that had been dealt with in due course. Either way, the general public wasn't informed of the possibility that any such conflict could, or might, arise in the course of the waterfront's redevelopment or the running of the Chaffers Park Design Competition. That no mention is made of Wraight and Athfield's prior involvement with Council work on both of these projects is a little harder to countenance, particularly in light of the number of commissions this team has been awarded over the years for the waterfront, the most recent being for the redevelopment of the Frank Kitts area into a Chinese garden.

At least with the newspaper perspective the waterfront debate is acknowledged, perhaps even exaggerated a little for good headlines. But simmerings of discontent are there, building up to a crescendo on several occasions over a fifteen year period, with the same complaints resurfacing time and again. That is, Council and its affiliate companies, Lambton Harbour Management Ltd / Wellington Waterfront Ltd, lack trustworthiness because they put profits ahead of people's wellbeing, and that the harbour's redevelopment is being mismanaged and consultation processes twisted, leaving the public out of the real decision-making loop. City Voice sees Wellington as a dysfunctional city, what with its despotic Council and barony of experts ruling the roost, with nothing short of a revolution being the solution. Daily newspapers The Dominion and the Evening Post, amalgamated into The Dominion Post, opt for a more restrained coverage of events. In their hands, the drama comes across as more muted but 
nevertheless conveys the strength of emotion felt by all parties concerned. At one moment citizens are being called to stand firm on the waterfront and not compromise their beliefs, while at the next Council is being given a chance to respond and act in a forthright and masterly way, with the resulting seesaw back and forth becoming noticeable in looking back over old newspaper headlines. How the showdowns eventually lead to Council making a graceful u-turn and taking up the park idea instead for the Chaffers site. But in thinking back to other versions of the story, the running of the competition starts to look more and more like a face-saving exercise, a means of recouping a bad situation and making sure Council's vision is imposed over others. The principles and values underpinning processes and structures get so little attention that it makes their shadowy presence stand out in sharp relief.

And although the people get the park they so badly wanted, the table gets turned on this success in a subtle way with the introduction of a competition. Council serves as its sponsor and overseer making it a clever tool for reasserting control over the waterfront situation while at the same time making the public look involved. Council takes matters in hand and makes sure its vision for Waitangi Park prevails, educating the public by raising their tastes in the process (Glazer 2007:44-45). However, no sooner is the new park laid down than controversy moves elsewhere, in the direction of other unwanted projects such as the Hilton Hotel and Overseas Passenger Terminal. The battle shifts to new locations along the waterfront, proving that the park's construction changed little in terms of relations between the public, lobby groups and Council. Indeed, proposed changes to the Resource Management Act leave things up in the air where resistance to Council's plans are concerned, it being uncertain what implications these will have on lobby groups' capacity to stop, or forestall, unpopular development. As to what moves, and counter-moves, are being planned - only time will tell - but the presence of lawyers on both sides of the debate suggests that litigation is in the offing.

By now the reader is beginning to twig that 'truth depends upon who picks the facts, who writes them down, and who reads them' (Corrick 2008:24). This awareness is unsettling, so too is the knowledge that more than one truth exists and that these can be conflicting at times. Faced with befuddling political and social maneuvers, the first impulse is to get shot of the whole business, there seeming to be no end to the battle and far too little generosity of spirit in evidence to reverse matters. However, rather than ignore anomalies there is another approach available that involves standing back and taking the longer view. With this in mind a literature review is presented in the next section, one that explores issues not yet touched upon in this thesis that relate to the nature of competitions and procurement practices, as well as their effect on governance structures and organization. In bringing to light information concerning the role of lobby groups in democracies, as well as the impact of land-use problems on social relations, new knowledge relevant to the Waitangi Park and the Chaffers Park Design Competition is revealed. A look at the politics of parks leads to a discussion of place as a process, and culminates in a review of another waterfront redevelopment project in Bristol, England, that indicates to what extent Wellington's experience is unique. 


\section{The Literature}

The literature review presents the scholars' perspective which has been gleaned from a variety of fields such as architecture, landscape architecture, urban and environmental design, business management, philosophy, political science, and environmental psychology. The intent, in casting such a wide net, is twofold: first, in stepping back and exploring conflicts from the vantage point of other disciplines, some not so obvious causes for conflict over waterfront redevelopment projects become visible. Second, in conducting an interdisciplinary literature review, gauging the type of contribution Sociology can make to such inquiries became far easier. With this in mind, let the story proceed.

\section{On the nature of design competitions}

For a 'how to manual' on running competitions, one need look no further than the New Zealand Institute of Architect's 'Handbook for the Organization of Architectural Design Competitions' (199[-]). This straightforward booklet lays out the responsibilities, roles, and processes associated with successful design competitions, as well as the special requirements and challenges likely to arise in their execution. According to this slim handbook, The NZIA endorses only competitions that clearly define rules and requirements, with events having to be overseen by professional advisers and evaluated by assessors representing both sponsor interests and appropriate expertise. Accordingly, the Institute does not support sponsors who run competitions without the guidance of the Institute or who undertake unfair, or inequitable, processes. When professional advisers are used to oversee a competition, then the institute recommends selecting those who are independent, impartial and objective to oversee proceedings. The key point to take note of here is that 'the advisor must have no interest in the project, as a designer, as an investor, as an employee of the sponsor or through association with any competitor' (NZIA 199[-]:4). Having said that, a competition's success rests largely on the quality of the design brief given to competitors, whose formulation is the adviser's responsibility. This person must be prepared to work with the sponsor, and take their specific needs into consideration. Where projects are very complex it is appropriate for technical specialists to be appointed, their function being to act as consultants throughout the competition, however the sponsor's employees ought not to serve anywhere in the competition process itself.

In terms of types, competitions can be broken down into three main ones: the project competition, the special purpose competition and the ideas competition. They are also classified in two other ways: based on eligibility, whether open to all or limited to professionals alone, and by their staging which has the option of being one, or twostaged. Ideas competitions are meant to be open to anyone, the procedure being that in their first stage a rough design concept is presented offering just enough of an indicator to the judging panel for them to make an informed selection. From there a decision is made as to which of these rough concepts is worth developing at the second stage of the competition. The expectation is that each competitor does his/her best to address the design brief, with the task of the adviser being to check this had been done, also to see to it that the sponsor's needs are being met. A check must also be made to make sure 
designers are being allowed sufficient leeway to express their interpretation. Naturally, it is up to the competitors themselves to study the brief carefully and respond appropriately, in order to avoid the risk of early disqualification. So where assessors are concerned, expert judgment needs to be brought to bear on competition submissions, noting:

The caliber and standing of each member of the panel should be of the highest order. Architects are willing to enter competitions where they can be confident of the ability of assessors to judge their work fairly and fully. The caliber of the assessor panel thus helps determine the quantity and quality of submitted designs.

(NZIA 199[-]:15)

This explains why some architects are choosy about which competitions they enter, wanting to be sure beforehand that those serving on a judging panel are independent and objective with no vested interest in the client's projects. Competition judges are not meant to be associated with any architectural practice, the rules for panelists being particularly stringent in this area. And because small countries, like New Zealand, have a limited pool of experts, the use of overseas judges is one way of getting around possible conflicts of interest, though this option is not always taken up for various reasons. Most of the important aesthetic decisions concerning competition entries are usually made by the architects involved, these experts being more knowledgeable and skilled at scrutinising plans and drawings than others on a judging panel. The architect is better able to visualise finished products from plans and determine whether a design can actually work, also whether the proposal is likely to fit allocated budgets, or not. The agency sponsoring a competition usually has representatives looking out for its interests, as well as members of special groups most affected by the project in question.

Successful competition outcomes depended largely on the jury, a group that is assumed to be experts in their respective fields. However, because a panel's members can hail from diverse backgrounds opinions will diverge, and sometimes markedly, with damaging results at times. So the selection of judges must be carefully considered in order to avoid problems. It follows that knowing something about a jury's composition can give a fairly good indication of the type of design a client might be looking for, also the final choice they are most likely to make. Sometimes information about the judging panel is available to competitors prior to a competition, other times not, making it a hit and miss affair for competitors. Although the public isn't normally made privy to the exchange of views that goes on between judges during deliberations, out of this dialogue emerges a preferred submission which is eventually agreed upon. After the selection has been made, reports are written justifying and explaining this decision which are then made available to interested parties. This is done in order to demonstrate to the client, the public, and losing competitors that the competition has been conducted fairly 'thus conferring legitimacy on the winning designs' (NZIA 199[-]:18).

In commenting on competition outcomes, Paul Spreiregen (1979) claims that design competitions are not 'intended as a tool for political or professional reform; their primary purpose is to concentrate on design; to find new possibilities; to embody a mood toward 
which a society is tending. Also to advance new ways for living that haven't yet been disclosed' (Spreiregen 1979:2).

Inevitably, this ideal falls short of expectations on occasion. Architects acknowledge that competitions are sometimes subject to misuse, having little in-built immunity against the effects of bad management on the part of sponsors. This explains, to some degree, why competitions are 'almost always accompanied by gossip, backbiting, arguments, quarrels, reproaches and vilification' (Haan \& Haagsma 1988:7). Part of the problem stems from the fact that there is 'only one winner coming out of the process' (Haan \& Haagsma 1988:12) which tends to cause jealousy amongst competitors and blur the issues.

It stands to reason that unless the sponsor has a strong motivation to search out the best available talent, there is little value in undertaking a competition. If that talent happens to already be at hand, then one can legitimately ask why the process has been undertaken in the first place given the time and financial commitment necessary for all those involved. In a sense, this makes every competition a yardstick indicating not only how well a designer responds to the challenge but, more importantly, how sound a sponsor's organization is (Haan \& Haagsma 1988:12). When everything goes according to the guidelines set, all is well, and things can proceed according to plan. However, when processes go wrong, then pre-existing problems tend to get highlighted with a tug of war ensuing between commercial imperatives and the more utopian ideas underpinning competitions. Part of the problem is that these events vary 'in accordance with the wide range of agenda' (McCarthy 2003:79). Christine McCarthy notes that criteria that are not particularly relevant can easily end up inhibiting the selection of more creative solutions precisely because they challenge orthodoxies. Equally, in awarding the prize to only one competitor, all those who have also participated feel that their contribution is being discounted, thus causing general ill-will. So it becomes crucial for those thinking of entering to consider the dynamics and structure of competition systems before taking part, the reason for this being that 'any architect who enters a competition solely to get the job will soon become disillusioned' (Strong 1976:14).

According to Judith Strong, competitors often make the mistake of expecting assessors to indicate what they are looking for, but if the sponsor already knew that, then there would be no point in holding a competition. What competitions processes do, in effect, is give designers an opportunity to prove themselves by coming up with a better solution than might otherwise have been reached by any other means. Owing to the considerable influence assessors have on the design brief, it is therefore imperative that they abide by the competition rules in order for trust in the procedure to be maintained. Consequently, mandatory requirements have to be made absolute and not be permitted to change once the competition gets underway (Strong 1996:18). Equally, 'since no regulations, however well drawn up, can preclude all possibility of disputes, provisions for conciliation and arbitration must be included in the competition conditions' (Strong 1976:145).

John Hunt maintains that design competitions come in many guises with some being precisely defined while others, 'one dare not speak of its name' (Hunt 2005:82). Cultural 
or civic projects whose intent is to have iconic significance are particularly challenging because they often incorporate conflicting requirements. Here, an intangible philosophical stance is expected of designers, meaning that often they have to incorporate ambiguous cultural meanings whilst intersecting them seamlessly with more pragmatic needs. What this does, in many instances, is expose divisions about architecture's responsibilities without giving an opportunity to resolve them because so little discussion takes place following competitions. Hunt finds this situation irksome but recognises the reasons behind the reticence, "sponsors are unwilling to have their project "exposed" in this way - occasional intemperate public comments by some members of the architectural profession must take some responsibility for this' (Hunt 2005:18).

However, without a dialogue about outcomes, it is difficult to determine vagaries in competition processes, the sponsors being left to distill the aftermath of emotionallycharged circumstances often all on their own. As to evaluating the considerable physical, economic and social impacts of competitions on the public, this task is just as important, if not more so, than preparing design briefs (Hunt 2005:18). This means that making provisions for discussing expectations, and disappointments, in the process is a way of keeping everyone in the loop. Plastering over aspects of a contentious competition damages trust and is against the interest of the public in the long run. This idea of having everyone 'au fait' with competition outcomes is supported by Kim Dovey who comments, 'to abandon the concept of 'public interest' is to abandon the concept of 'public space' because the sharing of space between citizens necessarily implies a shared interest in its possible transformation" (Dovey 2005:2).

The notion of 'public interest', though it appears stable, is actually more constructed than found, often masking the dominance of certain interests and the marginalization of others. Amidst this, what the 'design drive' underlines is the existence of 'public/private partnerships under entrepreneurial modes of urban governance' (Dovey 2005:2). What this means in effect, is that public interests become little more than 'place myths' made up through advertising. By blotting out the tension between private and public interests, through the limiting of public imagination, political legitimacy is given to mechanisms used in favouring one type of development over another. And when understanding is curtailed, a debate is effectively over if not entirely eliminated, with democratic planning being unable to reverse a conflicted situation. The source of the problem stems, it seems, from the very wealth generated by waterfront planning and design initiatives which actually benefit few directly because 'the vast majority of those who will share it have not yet been born' (Dovey 2005:2). This gives urban design and planning decisions wider ramifications than even imagined, and goes some way towards explaining why critics of redevelopment strategies can become so enraged. They realise that the consultation exercises built into projects are insufficient avenues for public participation in decision-making, signaling the need to challenge unilateral, or singular, ways of 'seeing' by questioning the vision and principles underpinning redevelopment strategies. The presence of tension reveals that, 'while private interests can service public interests, the public-private partnership embodies a conflict of interest at its core' (Dovey 2005:247). 
So place-making practices are not straightforward because they conceal contradictions between creating and protecting which become embodied in regulations and processes (Dovey 2005:232). Those planning and designing cities are so caught up in this conflict of interest that it becomes second nature. And with competitions being the very lifeblood of architecture, claims of anomalies in the very fabric of the profession are unlikely to be welcomed with open arms. Lars Bergström (1970) points out the near impossibility of deciding what conflicts of interest really mean owing to the fact that they are rarely free of ambiguities, making it especially hard to analyse them with neutrality. According to Bergström, conflicts of interest are caused either by a 'state of mutual antagonism or hostility between two (or more) parties', or as a result of 'the incompatibility of interests (values, etc.) which might in turn give rise to antagonism or hostile behavior' (Bergström 1970:198). At the core of these conflicts is rivalry, where interested parties consciously jockey for position with each being unwilling to accommodate the wishes and needs of the other. The point of such struggles is to eliminate rivals, or at the very least neutralise them.

But in considering any conflict, it pays to remember that the tension resulting from it usually rests in the system that created the hostility, or frustration, in the first place which can simmer away for years. It can be latent most of the time, yet go on to manifest itself overtly when triggered by some seemingly innocuous situation arising in the normal course of events. All of a sudden, conditions appear to become intolerable and an open conflict breaks out, or re-erupts, seemingly out of nowhere. It was only with a full understanding, or conscious awareness, of the other's wishes that the 'incompatibility of potential future positions' became fully apparent (Bergström 1970:199). Therefore where resolution is wanted, it pays to be able to distinguish what type of conflict is actually in question because 'to eliminate hostility is one thing; to eliminate incompatibility (of interests, for example) is quite another' (Bergström 1970:199).

Bergström explains that when interpretations of 'conflict' and 'interest' vary, as they often do, conflict resolution is particularly fraught. In attempting to determine what interests are, there is always the inclination to identify interests with what seems desirable to attain at the time. This kind of interest can be subjective on the one hand when it relates to demands and expectations, and objective on the other when a party becomes aware of a right whose attainment is within conceivable reach. Whether aspired to, or not, both types of interests require a moral decision to be made and for a position to be staked. Either way, what this sort of situation makes clear is the nature of relations by highlighting the distinction between those with authority to make decisions and those without it (Bergström 1970:202). And when interests are at odds, both in substance and direction, they end up serving as the source and orientation behind all forms of action, whether positive or negative. Curiously, the position, or location, of a conflict has little impact on relations or on behavioural responses.

'For example, it would be odd to say that there is a conflict of interest between two parties if each of them can very easily remove the barrier to the joint satisfaction of their interests and if they know quite well how to do this.'

(Bergström 1970:209) 
The problem, then, rests in determining whether the conflict of interest is real, or not, and in order to do this one needs to ask whether the parties are really in conflict; what the origins of the conflict happen to be; and whether the interests are compatible or incompatible between conflicting parties. Finally, whether there is any possibility of reconciliation and by what methods this might be accomplishable. If it turns out that interests are not incompatible after all, then the conflict never really existed in the first place, but if it resulted from some sort of propaganda, or indoctrination, then again the problem isn't real, even if incompatibilities emerge. If it can be shown that a barrier to joint satisfaction is removable by intervention, then the conflict isn't really present once the impediment has been removed. So only where the barrier is beyond human control do conflicts become truly insurmountable, making them irreconcilable, and this is what has to be proven in order for a conflict to actually exist. Given that the resolution of most problems is within our grasp, the real issue revolves around making a distinction between the elimination and suppression of conflicts. Here, Bergström reminds us:

'A conflict which is eliminated does no longer exist, whereas a conflict which is merely suppressed does still exist, even though, roughly speaking, it has somehow become latent or is less likely to give rise to violence or hostility than it used to be. We may also say that a conflict is suppressed if the parties have accepted to live with it. Thus, certain kinds of compromise represent suppression rather than elimination of conflict.'

(Bergström 1970:212)

By far the commonest way of ending a conflict is through avoidance, this being the preferred means of eliminating a problem and making the rival party go away. However, for incompatibilities to really be removed, once and for all, a structural change has to take place, effectively breaking down barriers and thus allowing progress to be made and finally satisfying the needs of all parties concerned. Where it has become impossible to achieve this goal, a modification of interests must be considered so that 'conflict conclusion' can take place. And when value systems are altered, willingly, and settlements accepted, rather than imposed, then justice is served and the source of an incompatibility eventually disappears. Otherwise, the only way of eliminating a conflict is through some really drastic act involving dramatic structural transformation, the impact of which is not always certain (Bergström 1970:213-5).

\section{Procurement practices}

If a conflict stems not only around who gets to decide how public land is used, but also around the processes used to make land-use decisions, then something more needs to be known about how places like parks are actually procured. As it stands, procurement practices must meet the demands of stakeholders such as the public, various levels of government, and different interests within the private sector. In 'Corruption in Public Procurement: A Perennial Challenge' (2007), Glen T. Ware, Shaun Moss, J. Edgardo Campos, and Gregory P. Noone note that 'most public procurement systems attempt to emulate the operation of the market, primarily by requiring competitive tendering procedures for major acquisitions' (Ware et al 2007:295). 
Public procurement tools, such as design competitions for parks, are run along strict guidelines that involve rules and bidding practices that are expected to be transparent, accountable and efficient in nature. Public officials are held responsible for proper implementation of regulations and for decision outcomes, with the violation of rules being circumvented by internal controls, audits, as well as a complaints system where challenges to decisions can be lodged and heard. That is why review bodies have the authority to correct anomalies and institute remedies so that procurement practices are seen to be above board and legitimate. When procurement processes are kept open, this imbues confidence in the whole system because it eliminates the opportunity for private gain by either government officials or private interest groups. By transparency is meant:

'[...] the ability of all interested participants to know and understand the actual means and processes by which contracts are awarded and managed. This requires the release, at a minimum, of information sufficient to allow the average participant to know how the system is intended to work, as well as how it is actually functioning.'

(Ware et al 2007:298) after (Wittig 2005:111)

Knowing how officials use their control over procurement processes is vital, particularly if the aim is to avoid any suspicion over dodgy practices. Potential problems are identified, then, by using red flags which go up under particular situations, such as when the same contractor seems to be getting preferential treatment and receiving what appears to be more than their fair share of recurrent awards. Another sticky situation is where former officials act as suppliers, or advisors, on projects for which they were previously responsible. Bid rigging is another problem area, and refers to situations where a competition has been manipulated so that a pre-selected bidder ends up winning the commission. This can be done by writing specific requirements into the bidding documents that only one particular competitor could realistically meet, either that, 'or the contract may be drawn up so that only one particular bidder will qualify and all others will be rejected as being unqualified' (Ware et al 2007:301).

Sometimes all it takes to skew a procurement process is to give a favoured bidder access to information not available to others. 'Inside information' enables the bidder to tender what is wanted and gives them more time than their competitors to come up with a polished proposal. Because of their subtlety these sorts of procurement problems are hard to spot and combat, indicating that however well conceived no system, or competition process, is ever completely free of risks. This makes an examination of potential vulnerabilities useful in terms of looking out for remedial measures and control mechanisms for reducing potential anomalies. But this can only be done if a problem is made apparent, or becomes visible, and owned up to. If a fatal flaw can be shown to exist, 'this distortion at the outset of a project may set up a dynamic that leads to bid rigging or collusion in later phases'(Ware et al 2007:309).

The way bids, or proposals, are evaluated can also throw up red flags. For example: 
'Some types of evaluation systems give public officials excessive discretion in decision making and thus are particularly prone to exploitation by corrupt public officials and the bidders who influence them. Although price is the most widely used evaluation criterion in public procurement, other, nonprice criteria are also commonly applied. [...] The extent to which these nonprice evaluation criteria are quantified and expressed [...] often largely dictates the extent to which the evaluation process is prone to undue or corrupt influence. The most vulnerable evaluation systems are those that convert evaluation criteria, and sometimes inexplicably, even price itself, into notional points, which are then awarded to each by one or more evaluators based on his or her own subjective assessment of the worth of the bid against each criterion. Under such evaluation systems, there is often no right or wrong answer in the decision-making process, as the winning bid is simply the one that receives the most points; in such a situation, the decision is wide open to corrupt influence, and it becomes all but impossible to hold the evaluators accountable for the correctness of their decision.'

(Ware et al 2007:314-315)

Other indicators of problems in procurement exist when vested interests are amongst members of bid evaluation committees, also where staff are involved in contract award decisions and in its supervision. This type of situation occurs when award and supervision are undertaken by the same procuring entity, also where high-level public officials sit on evaluation committees that intervene in the processing and ranking of bids with the specific intention of changing results. What is important to note here is the way complaints about process and evaluation are handled when they arise, the presumption being that a mechanism exists for receiving and dealing with complaints, though this isn't necessarily always the case (Ware et al 2007:316). These types of considerations rarely enter the mind of an inexperienced competitor who assumes a process is fair to begin with and that avenues of redress exist, should worse come to worse. The enthusiast, caught up in the excitement of the moment, is therefore far less likely to be on the lookout for problems from the outset. Only seasoned pros think to check whether provisions have been made in the process for dealing with real, or perceived, anomalies because they know from hard experience that not all systems are equal (Ware et al 2007:316).

\section{The role of lobby Groups}

Lobby groups are better at getting a response than lone individuals because they can bond people together in the face of adversity, making it much harder for a local authority to ignore them. Indeed, wherever issues requiring common action exist, lobbyists will be found, attempting to influence decisions without actually exercising formal powers. The reason for this has to do with the nature of the driving force behind them, which is not so much politics but the protection of perceived rights. The longer a lobby group manages to survive in the public arena the greater will its credentials and influence become, often leading to fixed patterns of achieving goals. 
According to Graeme Moodie and Gerald Studdert-Kennedy (1970), lobby groups establish themselves with the sole purpose of making sure power is evenly distributed so that no one body can continuously exercise control without undergoing some sort of challenge. The point here is to secure some power as a way of safeguarding the ability of outsiders to participate in decision-making processes, otherwise the public risks being totally sidelined. Indeed, in many instances lobby groups are the only reason why discussion between the public and power holders takes place at all. So pressure groups exist to supplement representation and to constitute 'public opinion' whenever a conflict arises with officials (Moodie \& Studdert-Kennedy 1970:13, 59). Because lobby groups can, and often do, oppose governments the idea of ignoring them is risky because once a battle is initiated anything can happen. The leverage power lobby groups hold is determined by two things: first, their ability to access decision-makers; second, to garner sufficient resources in undertaking a challenge. How these resources are exploited, and controlled, signals the amount of power any one group ends up exercising in a power struggle. Since influence can be purchased and resources easily mobilised, when the cause emerges where lobby groups believe they aren't getting a fair hearing, trouble is likely to ensue. This happens because resistance, along with other forms of noncooperation, actually works and is therefore the most popular strategy lobby groups use in voicing their concerns. Pressure tactics are also used in forcing a local authority to reconsider their position, the impact of large numbers of supporters being sufficient to bring about wanted change (Moodie \& Studdert-Kennedy 1970:67).

When a sense of mission exists, enrolling the public's support is made easier, so too when lobby groups are driven by a sense of moral outrage over unpopular decisions. Then people want to take part and become involved in what they see as a worthy cause. The mere fact that an official body, like a local Council, can be forced into justifying their actions is sufficient proof of lobbyists' power. And if mistrust can be created in a process of challenging these bodies, lobby groups will do so willingly in a bid to better achieve their ends. Their point is to get policies and decisions reviewed by any means possible, and get opponents to look at new perspectives as well as take into consideration other arguments and possibilities. However, lobby groups are not without their own internal problems in the form of entrenched attitudes which tend to limit their effectiveness. Also, preserving integrity can prove something of a challenge, particularly when a stance is taken that is very much at odds with a powerful local authority. Further, serious conflicts of interest are also possible within voluntary agencies, not just large institutions. Much, then:

'[...] depends upon the constitution and the general political context whether pressure groups operate as a force for enlarging the circles of informed involvement or whether they contribute rather to the creation and maintenance of an exclusive inner circle for confidential bargaining and discussion.'

(Moodie \& Studdert-Kennedy 1970:96)

So, in order for lobby groups to be 'actual or potential catalysts of general public involvement' (Moodie \& Studdert-Kennedy 1970:109) and bring benefit to communities 
their potential for disruption has to be more than just well-intentioned but underpinned by sound principles and values, otherwise their persistence serves no one but themselves. If lobby groups turn into small dynasties, then the motives underlying their actions and claims become no less suspect than the opponents under challenge. Similarly, when opposition is allowed to become so entrenched that any, and all, actions undertaken by an adversary is sufficient to cause a long dispute, then something is amiss. When this situation occurs, their ability to pick and choose fights has been forsaken with everything leading to a battle. This is not only an uncreative response, but an unsustainable one as well, with the ceaseless bickering souring relations all around and eventually driving off even the staunchest of supporter out of sheer exhaustion and disillusionment.

\section{Land-use problems}

Thomas Guterbock (1980) explores the way alternative land-use patterns affect people's response to a place, and the impact of governance practices on the conditions surrounding land-use problems. In listing the criteria by which the general public judges long-term effects to be 'bad', the origins of detrimental land-use patterns become visible, as are the issues of viability and equity. According to Guterbock:

'We need to understand the causes of land-use patterns; also the process by which people make land-use decisions in different contexts so we can evaluate various institutional frameworks for land-use control and thus choose among alternative change strategies. Social science research can provide this.'

(Guterbock 1980:246)

By making new patterns of expansion more compatible with old values, less disruption takes place because a balance is being struck between founding and preservation, claims Peter Cannavò (2007). For a city to survive both are needed, however most developments end up being contested precisely because different perspectives and values end up clashing at decision-making levels. When debates over land get taken to extremes, as they often do, opponents attempt to exclude each other from full participation. Often, this is done by 'delegitimizing opposing voices, branding them as enemies of progress, or environmental despoilers', which is less than helpful (Cannavò 2007:225).

Best practice indicates that it is therefore critical to make sure all stakeholders are part of 'a collective voice in the management of a place - whether private property or an area under the jurisdiction of a particular government entity' (Cannavò 2007:226). The point of getting everyone involved, notes Cannavò, is to encourage plurality and to make sure the field of possibilities doesn't become narrowed down inadvertently. Any attempt to deny the politics of difference by either ignoring, or downplaying it, is likely to have a detrimental effect on place attachment, and lead to eventual conflicts of one sort or another. The ability to see things from other people's perspective is important then, so shouldn't be treated as salutary, or as part of some public relations exercise. This is because when people are excluded from participating, all sense of partnership is shattered, making institutional structures for deliberation ineffective at best, and inappropriate at worst. Equally, when no other avenues exist for working out differences, 
or getting unwanted projects stopped, the public finds itself forced to resort to court action against local authorities and private developers. And when challenges are successful a modification in expectations occurs, causing new patterns of interaction and response to evolve. If demands aren't being responded to, rather than initiate a dialogue, stakeholder groups will get into the habit of skipping directly to litigious models of interaction in the knowledge that these are more effective. When this occurs, all semblance of democratic participation is given up. Nor is it always the most viable, or sustainable approach, given that even the strongest lobbyists are unable at times to counter enormous developments, the stakes being too high. The scale of these projects far exceeds the scope of most groups, creating a sense of powerlessness in the face of massive disruption. With this sort of scenario, decision-making ends up being done for the public by others, rather than through any sort of real agreement, guaranteeing frustration (Cannavò 2007:227-8).

\section{Place as a Process}

David Smaldone, Charles Harris and Nick Sanyal (2005) note that most studies about place meanings and people's attachment to them, deal almost singularly with positive aspects of place-making. They believe this is a shame because 'a better understanding of the negative aspects is needed to be aware of the full spectrum of place connections and disconnections' (Smaldone et al 2005:412). Typically, negative experiences are understated, or even overlooked, because too little is understood about the fluid and shifting nature of people's relationships with places. Because places are given their meaning through a variety of means, and in response to numerous influences, this indicates that a place ought to be conceptualised as a process, rather than a static entity.

Since ties can be made, or severed, according to circumstances and preferences, the same place is capable of going from hospitable to uncomfortable over a period of time, or vice versa. In setting up an emotional bond with a place, specific events also have an impact, meaning that certain places can evoke, and reinforce, both good and bad feelings. When people speak of feeling rooted to a spot, or that a place is part and parcel of them, this shows a clear commitment to existing in a particular spot and explains why the loss of a particular place to a community can be upsetting, even devastating. Equally, it demonstrates why the imposition of an unwanted development affects commitment in a negative way through a real, or perceived, deterioration of conditions (Smaldone et al 2005: 411).

\section{On the Politics of Parks}

Galen Cranz writes of public parks as an ongoing process, sighting the five models that have guided American thought and influenced park design world-wide. These include: the pleasure grounds 1850 - 1900; the reform park 1890-1930; the recreation facility 1930-1965; the open-space system after 1965; and the latest model, the cultural park. Each, according to Cranz, embodies a different underlying principle that reflects the social and cultural world from which their designs have emerged.

To our modern eyes the pleasure grounds of the past look fairly docile, however 'this idea that they were merely passive is a self-serving comparison made today to rationalise our 
parks not being as rich and complex as the pleasure ground, which was intended for both active play and contemplative experience' (Cranz 1994:118). Pleasure grounds are in fact the result of a public movement originating in the $1850 \mathrm{~s}$, whereby a conscious decision was made by local authorities to do something about the high rates of cholera epidemics in large cities, particularly during the summer. Concerns over high density, and growth problems, were also a significant factor in bringing about these beautiful, green spaces.

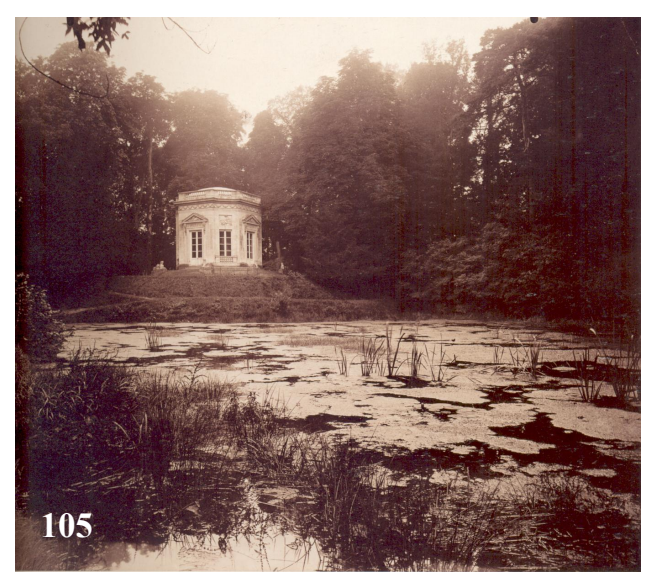

In response to agitation, legislators purchased land with public money in order to create large, open spaces for development into parks, with bits of land being been made available for such purposes by donation. Eventually, municipal governments went ahead

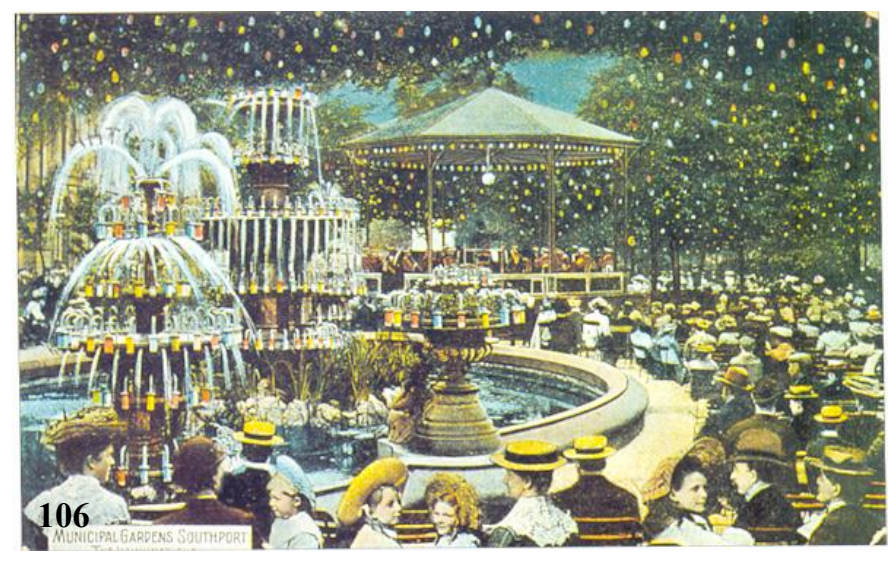
and did something to ameliorate the lot of city dwellers, usually buying up the cheapest and least desirable sections for building new parks. This meant these spaces were on the periphery of cities, and towns, on rather compromised sites. In terms of design, pleasure grounds were given curved meadows and undulating paths, because pastoral ideals were thought to be the perfect antidote to the congestion and stresses of city life, fields supposedly having something of nature and culture to them. Architecture played only a minimal role in these parks, native trees being their main focus along with water features which were meant to evoke a sense of serenity (Cranz 1994:119).

The Reform Park of the turn of the century, 1890-1930, represented policymakers' recognition that unless the working classes could also visit parks, then the instruction encoded in open spaces was being wasted. Therefore, it was decided to locate reform parks closer to the working populations living in tenement districts.

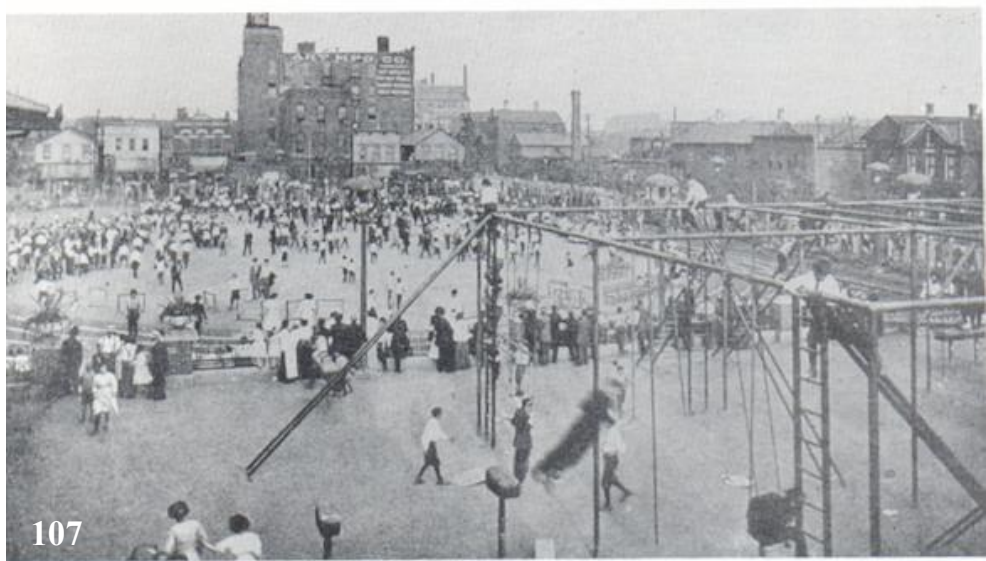
These parks, not surprisingly, were much reduced in size with all allusion to the pastoral 
abandoned in favour of strict symmetry. Here trees were used only to decorate edges with interior recreation replacing outdoor activities, spontaneous play no longer being trusted for some reason because people were thought to require supervision even in recreational pursuits. Regimented exercise was in, meaning that segregation of the sexes became the norm and play equipment became less for recreation and more to foster physical development (Cranz 1994:120).

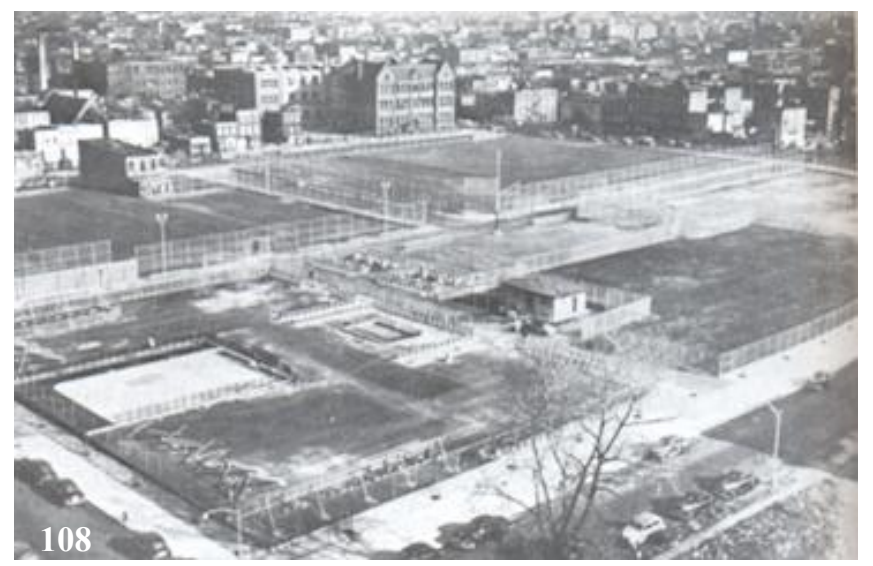

The Recreation Facility Park, 19301965 , represented another shift in park principles with old attitudes being rejected by public officials and planners who now no longer sought to use the spaces as a way of solving urban problems. Social agendas were out, with parks being returned to places for spontaneous fun. This move revealed the beginnings of a market mentality that emerged in response to municipalities not having a clear idea of what problems they were actually trying to resolve with open spaces. With this loss of ideals came banal park designs where greenery was no longer thought essential. The fact that large numbers of people still attended these bleak parks, in spite of their drabness, was proof that trees weren't actually essential, which lead to ugly blacktop surfaces and miles of cyclone fencing surrounding them. Here ease of maintenance seemed to outweigh any consideration for the public's wellbeing (Cranz 1994:121).

The Open-Space System, which emerged after 1965, marks a new era where city parks are used as a plank in the political platform of politicians, as well as agents of social reform for policymakers. Parks were less about recreational designations, and more about the potential of any space to provide recreational experience to its users. With sufficient imagination, any

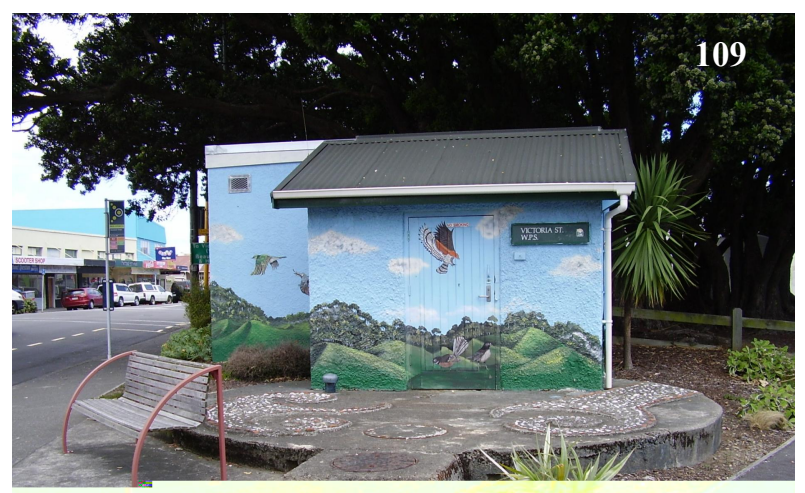
space would do, even walking down the street, the message here being that daily life, if seen in the right way, had an aesthetic component that could be tapped into by open-space planners. Henceforth, recreational experience need not be confined to park areas alone, with streetscapes affording just as much fun as open, green spaces. Out of this came two new models for parks: the adventure playground for children and the vest-pocket park for middle-class shoppers and office workers. This sort of park marked a major departure from the old recreation-facility standards, what with their tiny size and the feeling of oasis they 
presented. Since these concepts translated into transforming any rejected plot of land into some sort of recreational facility, this meant that planning standards were abandoned

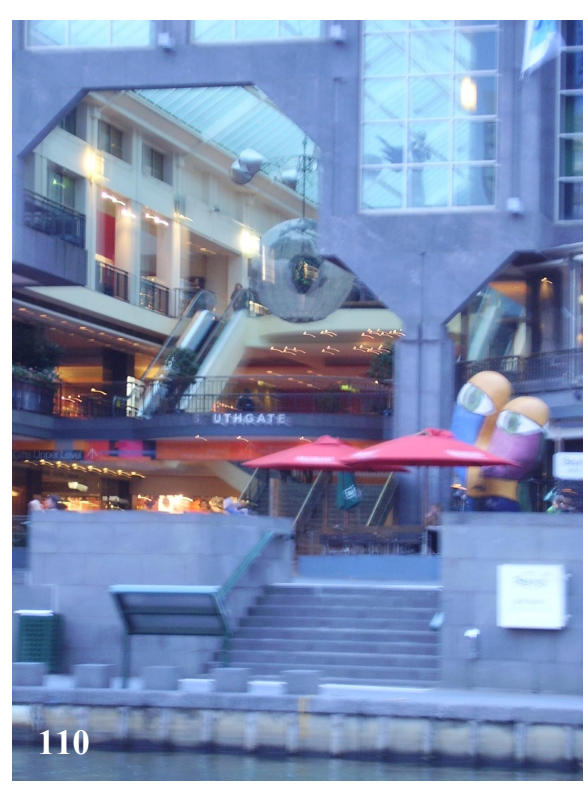
and replaced with a 'get it where you can' mentality (Cranz 1994:121-122).

From this evolved the fifth model, the Cultural Park, which carried over many of the ideals seen in the open-space system, yet conveyed an altogether new attitude towards city living. Whereas the pleasure grounds saw cities as a necessary evil, and park spaces as some sort of antidote to urban squalor, cultural parks took the opposite stance. Living in the city was now considered worth celebrating, making them into pieces of art that glorified contemporary life.

Framed in this way, even the chaos of city life could be made to look orderly and meaningful, with this model of park attempting to turn the city and even its problems into virtues. The principles of composition and design adopted for these spaces were not so much about hiding and compensating, but rather about enhancing and celebrating what

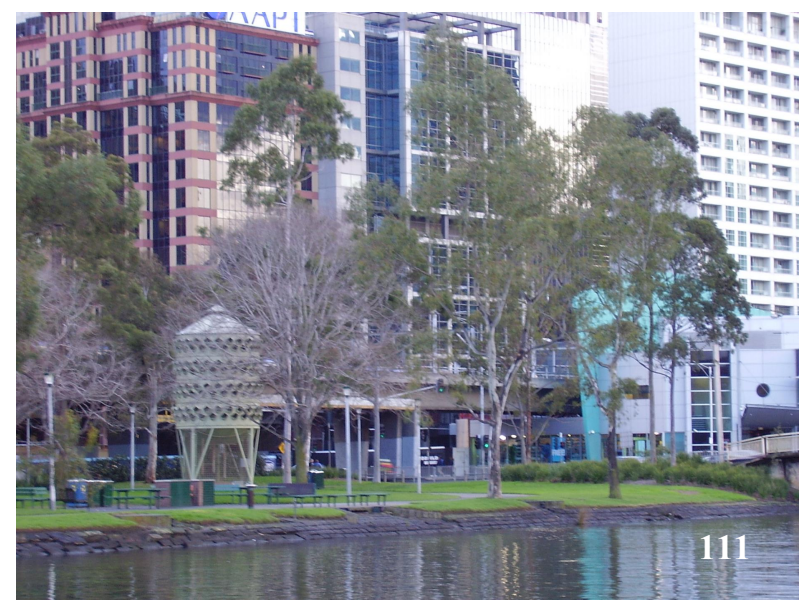
remnants of nature existed, making these parks the very embodiment of ecological, recreational, cultural, and political concerns (Cranz 1994:122).

Laura Verdi also views open, green spaces as the scene of power where concepts of 'enterprise culture' are clearly evident. She studies parks and gardens that have been

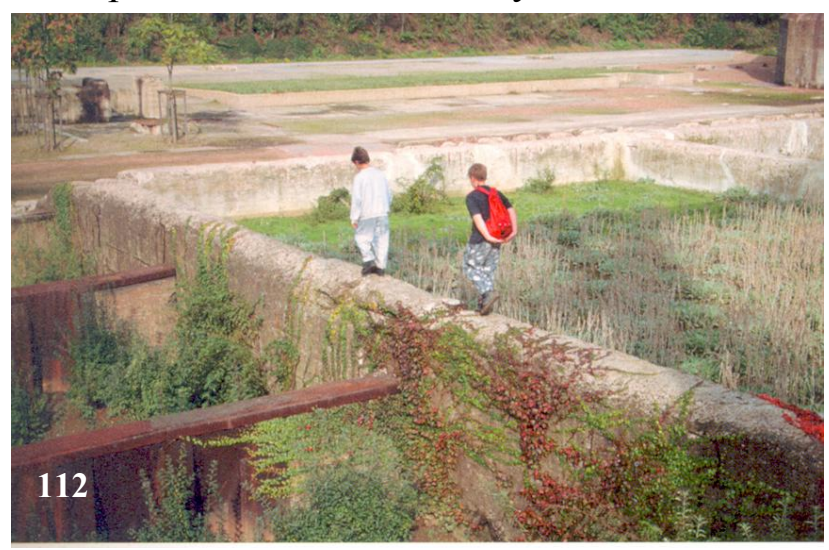
created out of former industrial areas because they embody a different system of representation, one that has emerged as a result of a new geography of cities. Within these radically changed urban environments, different models of complex power are said to be in the process of emerging, replacing what has now become old perspectives of park functions. Outmoded ideas are being swept aside for more flexibly multifunctional ones in a bid to re-create a bond between art, nature and man which, according to Verdi, 
makes for problematic sites. This is because these unique parks are without any real referent being 'artificial landscapes and spaces burdened with so many elements that the unitary sense of the project itself goes astray' (Verdi 2004:383). The ambition of representing democratic practices through these open spaces remains purely symbolic at this stage, with attempts to fulfill their promise as yet unachieved.

Keith Bassett, Ron Griffiths, and Ian Smith explain why this might be so using the city of Bristol, England, as a case study. Here, they analyse the ins and outs of a waterfront regeneration undertaken around the time of the Millennium, an example that highlights changes in the structure of governance practices. They also discuss how attempts to build a city-wide consensus around this project are marked by conflicting views and contrasting visions, bringing into question local authorities' ability to deliver on policy objectives. Here, the authors draw attention to two key points; first, that Councils have to be prepared to collaborate and co-exist with a much wider range of agencies and interest groups than previously, making the task of coordinating large developments even more complex than usual nowadays. Secondly, that the trend of using these projects as 'symbols of the successful transition to a new form of governance' (Bassett et al 2002:1757) is not always panning out according to plan.

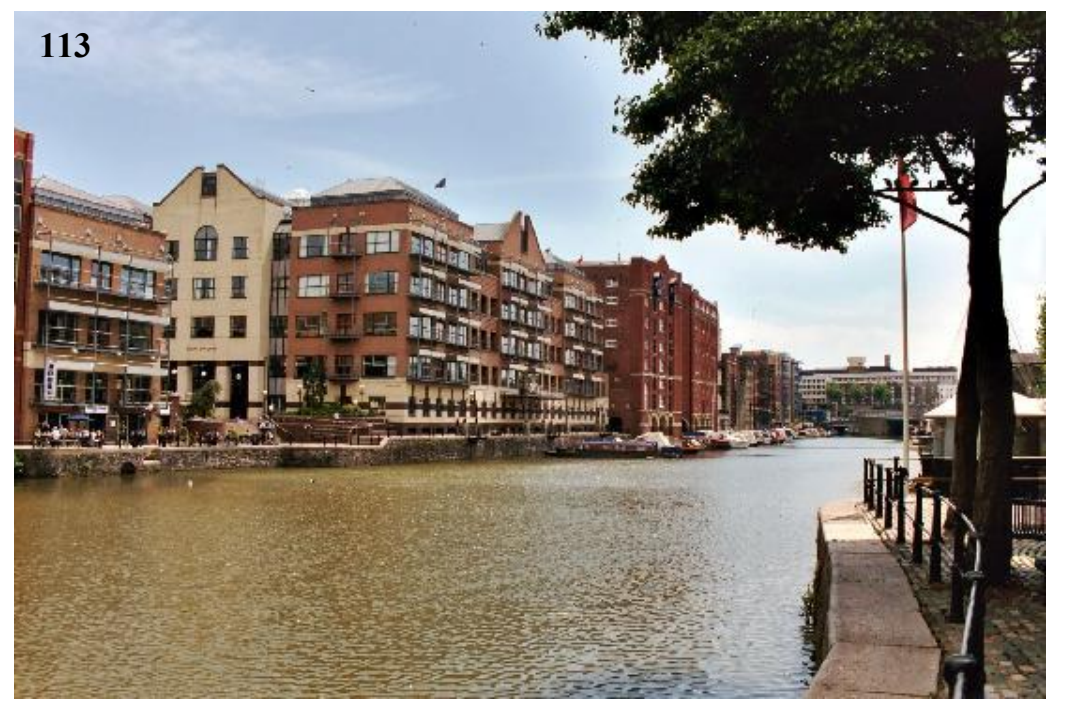

The intention behind this massive project was to mobilise the wider community and get it working more effectively with the local Council, and although this strategy had seen good outcomes elsewhere, in Bristol's case it turned out to be extraordinarily controversial and divisive. This was due primarily to the way the development showed up weaknesses and strengths in local systems of governance. When a failure of this magnitude occurred, it did so on a grand scale bringing to light problems in the power structures, political agendas, and decision-making processes. Because waterfront projects represented a cumulative experience, with the quality of relations becoming all too apparent, they were capable of changing management practices as well as patterns of local governance for either the better or worse (Bassett et al 2002:1764). In successful cases working partnerships developed, showing that confrontation need not necessarily be the norm; that co-operation was possible between various elements such as culture, commerce and residential development. However, it took a certain will-force for this to happen which explained why unsuccessful redevelopments could prove so demoralising to a city and its people. 
Where Bristol was concerned, problems arose around ownership, the securing of sufficient profits for developers, funding for cultural projects, and infrastructure issues. At first, public criticism of the proposed waterfront plans was muted, but this quickly changed into full-blown opposition when the size of buildings and their location became clear. Sightlines to the harbour were about to be blocked, prompting the ire of local residents, amenity groups, and local architects alike who were deeply unhappy about the vision being put forward by planning committees. Opposition was mounted by different societies, as well as local Councillors, with battle lines being drawn 'around a series of key development and design issues' (Bassett et al 2002:1766).

Cannon’s Marsh Amphitheatre, Cannon’s Way, Bristol, City of Bristol, UK.

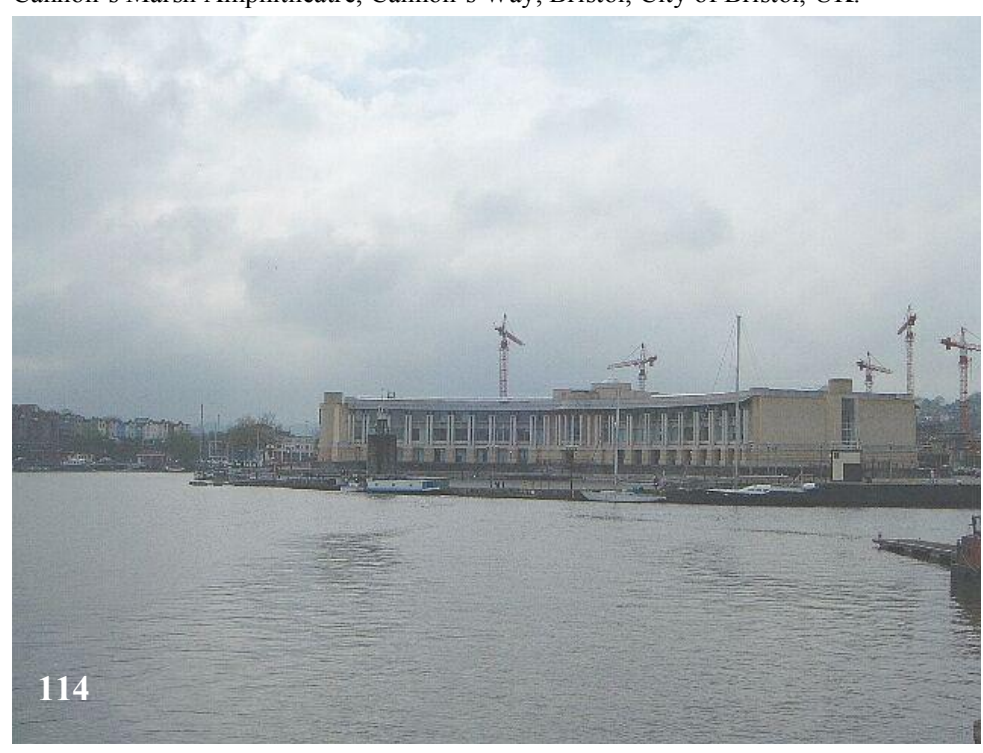

As the conflict deepened, plans and counter plans were devised including the submission of completely alternative plans for Bristol's waterfront, with websites being used to present the developers' schemes as well as those created by detractors. Rivals fought it out on-line, and at public meetings, where submissions were tendered to local Council voicing criticism over the project's economic viability, building heights,

and design quality. Although local governance practices changed in response to the battle of Cannon's Marsh, important lines of fracture outlived the immediate fracas in the form of competing urban visions and agendas. This demonstrated the limits of a Council's ability to deliver on large-scale developments, particularly its inability to forge a coherent agenda around concepts of urban renaissance, sustainability, and mixed-use development (Bassett et al 2002:1773).

All of which sounds vaguely familiar. 


\section{Third Evaluation}

In exploring the scholars', and other professionals', perspectives on competition and procurement practices new information comes to light that justifies having cast a wider net in searching for answers. The reader is made aware of some of the problems that arise in procuring large, iconic objects such as waterfront redevelopment projects, and how difficulties mount in attempting to balance conflicting requirements. The Chaffers Park Design Competition exposes divisions within the architectural community, as well as between lobby groups, the community and local Council, for reasons that are now much clearer. Because mechanisms for resolving public land conflicts appear to be negligible in this case, it is easy to understand why Wellington's waterfront debate has dragged on for years, and why opposition to Council's strategies tends to flair up at a moment's notice whenever something new, or unpopular, is proposed.

Nor do the doubts end with the selection of a winner in this case. Events leading up to, and including, the competition magnify the effects of both good and bad management practices, making this public event a good indicator of the state of relations in Wellington. Though design competitions are not meant to be used as tools for political or professional reform, the allegations levelled at this particular one nevertheless tells us a great deal. If the competition was a sham and finalists wasted their time, and money, competing in an event that they had no show of winning, then mistrust in Council will persist and even grow.

The independence, impartiality, and objectivity of Council's professional advisors will eventually be called into question, drawing attention to the limited pool of experts available in a small country like New Zealand. That the judgment of outsiders is not always welcomed in some situations, or even appealed to, also raises queries, for good reason. As sponsor and overseer of the design competition Council is already in an awkward position, so to discover that the winning proposal is the brainchild of designers previously engaged to work up ideas for the waterfront and park makes the notion of a conflict of interest all the more plausible. However, evidence proving that the competition was used by Council as a means of getting its scheme through with a minimum of public resistance, is rather thin on the ground. Nonetheless, in allowing the past to re-emerge the question does get raised, casting doubt on the process and principles underpinning not only the competition structure but Council's consultation practices.

Though 'ideas competitions' are meant to allow everyone a chance to participate, this story suggests that those outside the inner circle got shunted aside and discredited, rather than praised, for their efforts. Claims that the judging panel is guilty of a miscarriage of duty are also hard to substantiate. Perhaps members of the Waterfront Development Subcommittee ought to be considered the real victims here, having had their authority smeared by what some consider a bunch of disgruntled losers suffering from a bad case of sour grapes. Whatever the case, in analyzing events surrounding the creation of Waitangi Park, it pays to be wary, to size up the various accounts and keep a sharp lookout for telling gaps in interpretation. Recriminations persist because nothing ever 
gets cleared up, with lingering problems being left unresolved to fester, adding to the layers of complexity with every passing year.

Although Council works hard to legitimize its position and takes great pains to produce official documents justifying its strategies and initiatives, because the conflict is never acknowledged and fully faced, Council's position is left weakened. Complaints, when they surface, are handled in a way that suggests a decision has been made to give up trying to satisfy all interests because it is impossible. This explains why a culture of ignoring opponents and trying to destroy them when they surface, ends up fueling the conflict. Council's defence becomes one of staying on message and collecting style points. Barriers are thrown up preventing engagement that might threaten Council's control, with the result that participation has devolved into a process of filling out of feedback forms, responding to pre-set survey questionnaires, going to formal workshops, and preparing submissions that appear to carry very little weight.

The Chaffers Park Design Competition begins to look like nothing more than a clever public relations ploy, one that was never really intended to create new and unique ways of relating, though few would be conscious of this. In taking a closer look at this event, red flags are brought to our attention, the vote issue and allegations of conflict of interest being uppermost. The confusion over the vote originates with lobby groups, not Council, since the latter made it clear from the outset that it would be making the decision concerning who won the competition. However, allegations of vote tampering by lobby groups comes from Council, an unfortunate move that is made worse by the artless incursion of professional institutes prepared to throw their considerable weight behind Council's choice and that of its technical experts. Finally the evaluation system itself left something to be desired, being a numbers game open to vagaries.

Holding a sponsor like Council accountable for the correctness of its decision is no easy matter, with few prepared to venture into this murky terrain. Better to accept the inevitable and move on to the next battle, there being no right or wrong in this instance. Better to use whatever has been gained from this experience, however negative, in more profitable areas. This allows complaints about structure and organization to slip by mostly unnoticed, which is a worrying trend, the assumption probably being that adequate provisions exist for handling such anomalies. In truth, people never consider the possibility of redress until a problem arises in their own back yard and they can't get it resolved satisfactorily. No great wonder then that the principles and values underscoring a competition process go largely unexamined, with no one stopping to consider whether it is being conducted fairly and squarely. The seasoned professional knows better, and is far more conscious of potential anomalies creeping into the exercise than the amateur who marches along blithely. Although the rules and regulations governing design competitions look to be carved in stone, in reality the goalposts do shift in midstream, as this story shows, leading to unexpected consequences for all concerned. This knowledge makes the letter written by Rachel Hughes to Wellington City Council, following her team's loss in Chaffers Park Design Competition, interesting for its tone as much as its contents. 
The Chairman

10 December 2002

Waterfront Development Subcommittee

P.O. Box 2199

Wellington

Dear Sir,

\section{RE : CHAFFERS PARK DESIGN COMPETITION}

The Chaffers Park Design Competition has allowed me the opportunity to be involved with the development of Wellington's waterfront, and I have very much enjoyed being part of the design process associated with the competition. The competition has allowed Council to explore a wide range of options for the Chaffers area and has allowed the public to clearly indicate the type of park generally preferred.

However, I have serious concerns with the final selection process, which occurred at the Subcommittee meeting on 25 November 2002. I believe the process did not fully acknowledge the public consultation carried out by the Waterfront Project Team, and did not present an objective and reasonable assessment of the scheme preferred by a large percentage of those consulted.

The results of the public consultation indicate a clear preference for Scheme D, over the selected Scheme A. The informal research at Shed 6 showed $59 \%$ of respondents "really liked" Scheme D, and $16 \%$ of respondents "really liked" Scheme A. The comparison of weighted scores showed Scheme D at 4000, ahead of all other schemes with a 1200 margin. The formal AC Nielsen research showed a similar result with $46 \%$ indicating Scheme D as their personal favourite and $16 \%$ indicating Scheme A as a personal favourite. The AC Nielsen survey respondents were also requested to rate the five designs against 12 criteria. Scheme D was rated highest above all other schemes on 9 criteria, equal first on 1 criteria and $2^{\text {nd }}$ and $3^{\text {rd }}$ on the remaining criteria.

I believe that there were anomalies with the selection process, which have led to my concerns, and these are outlined as follows.

- The Technical Advisory Group (TAG) appeared to give a very heavy weighting or bias to a particular design style of park, even though the Subcommittee decided to explore different design styles when selecting the five finalists from Stage 1.

- The AC Nielsen survey and TAG completed a ranked comparison of the Stage 2 finalists. The AC Nielsen comparison was based on assessed ratings against 12 criteria, using a maximum score of 10 . The TAG comparison however was based on ordered rankings (i.e. $1^{\text {st }}, 2^{\text {nd }}, 3^{\text {rd }}, 4^{\text {th }} \& 5^{\text {th }}$ ) of the five finalists, and these rankings were then used to indicate whether or not a scheme met the assessment criteria.

- The Competition brief required finalists to submit a fully coloured and detailed model to allow the designs to be easily understood by all. TAG and Council advisors then cautioned the Subcommittee against the more accurate models, thereby discrediting the public assessment process and giving more weight to the TAG advice, which favoured a scheme with a more abstract model. 
- TAG and Lambton Harbour Management Ltd's treatment of budget and related issues were inconsistent and not fully transparent. Scheme D was presented to the Subcommittee inaccurately on areas of budget deletions, particularly the small boat ramp, the Clyde Quay Boat Harbour foreshore landscaping, and the lighted harbour poles illustrating the spiral. Scheme D was presented as having related extensive external works (Te Papa foreshore treatment). Advice from LHML indicated separate funding may be available for this work, and deletions in this area were made to a number of schemes without disadvantaging the assessment of those schemes other than Scheme D.

- TAG assessment on some criteria appeared inaccurate in relation to Scheme D.

- Scheme $\mathrm{D}$ was presented as having $5,700 \mathrm{~m}^{2}$ of green space. However the design actually includes $8,000 \mathrm{~m}^{2}$ of predominantly green open space (includes two adjacent lawn areas separated by a flat promenade).

- Similarly it was advised that Scheme D did not meet the waterfront framework criteria and lacked access to and continuity of the existing waterfront promenade. The waterfront promenade in Scheme D continues uninterrupted from Te Papa to Oriental Parade, as indicated on the drawings.

- Scheme $\mathrm{D}$ was assessed as having 210 carparks. The design included 70 carparks under a plaza building east of Herd Street building. Although the plaza building was deleted for budget reasons, the existing carpark in this location could be utilised, giving a total of 280 carparks.

- The selected Scheme A did not receive the level of scrutiny TAG directed at Scheme D on issues of building use (residential?), carpark allocations (in relation to building/park use), budget deletions (wetland canal walls), and traffic flow (particularly Oriental Parade to OPT).

- Council officials made inflammatory public commentary in the days before the Subcommittee's deliberations, seemingly casting doubt on the public voting process and this point was then taken up at the Subcommittee by two Councillors as having credence.

- TAG failed to address cultural and artistic merit accurately as technical advisors. Scheme D worked closely with renowned Maori artist Robyn Kahukiwa on key issues relating to the theme and intent of the Torino design and related artworks. All Maori aspects of the design were also discussed or developed with the Wellington Tenths Trust. TAG and others described the Scheme D Maori features as "tokenism".

- Scheme A was rated highest by TAG for the provision of 15 different "activity areas". However assessments did not expand on the relative cost and quality of the schemes' activities. The Subcommittee elected to review the scope of activities in Scheme A. However the impact on budget was not fully identified. Scheme D activities, artworks and park furniture were budgeted at $\$ 2.4 \mathrm{~m}$.

- The buildings on Scheme A may be subject to reduction in height. The budget impact of modifications to the proposed buildings resulting in possible devaluation of site revenues was not fully identified.

- The Subcommittee, after some 3 hours of discussions, informally voted 4:4 between Schemes A \& D. Why was the public's clear preference for Scheme D not then used to break the Subcommittee's deadlock?

For a more balanced view of the designs, I believe TAG should have been more broadly representative and the Subcommittee given a less subjective and better representation of specific design aspects of each scheme and the design style adopted e.g. 
- The allocation of budget use for each of the schemes' major design features should have been made clearer.

- TAG should have more clearly presented the relationship between building use, park use, allocation of land use, car park allocations to buildings and park and space use.

- TAG should have assessed each scheme on the criteria (as did the public) and not ranked each Scheme 1 to 5 on each criteria - this was misleading.

In essence, I believe Scheme D was inappropriately assessed, was not presented in the same context as afforded Scheme A, and both the Scheme D design and the public did not really get a fair go in what was deemed by Council to be a "competition". Therefore I feel it is necessary to advise the Mayor and Councillors of my concerns and to provide them with detailed information regarding the assessment of Scheme D.

Yours sincerely,

Rachel Hughes

Although the merits of Rachel's complaints concerning the competition process are hard to gauge, her sense of moral outrage in the way Scheme D was assessed is clear enough. Council's evaluation process for the five finalists was based on eight criteria, as shown in the graph below published by Wellington City Council in its Review of the Chaffers Competition, Stage 2, 18 November 2002, as prepared for the Wellington Waterfront Development Subcommittee by its Technical Advisory Group. In a presentation of the review, individual scores are averaged out with Scheme A receiving 1.4 while Scheme D only manages 4.0, indicating that the latter failed to meet criteria in several areas. Number 1 represents the highest attainable score, number 5 the lowest.

$\begin{array}{lccccc}\text { Criteria } & \text { Scheme A } & \text { Scheme B } & \text { Scheme C } & \text { Scheme D } & \text { Scheme E } \\ \text { 1. quality } & 1 & 3 & 2 & 5 & 4 \\ \text { 2. safety \& activity } & 2 & 4 & 1 & 3 & 5 \\ \text { 3. arts, culture } & 1 & 4 & 2 & 5 & 3 \\ \text { 4. accessibility } & 1 & 4 & 2 & 5 & 3 \\ \text { 5. Herd St. P.O. } & 1 & 2 & 3 & 4 & 5 \\ \text { 6. Chinese garden } & 3 & 5 & 1 & 2 & 4 \\ \text { 7. transition zones } & 1 & 2 & 3 & 4 & 5 \\ \text { 8. infrastructure } & 1 & 2 & 5 & 4 & 3 \\ \text { Average } & 1.4 & 3.3 & 2.4 & 4.0 & 4.0\end{array}$

Nor is the response Rachel Hughes receives from Wellington City Council likely to mollify her anger. 
19 December 2002

Rachel Hughes

WELLINGTON

Dear Rachel,

\section{Re: CHAFFERS PARK DESIGN COMPETITION}

Thank you for your letter about the Chaffers design competition. I agree with you that the competition has allowed the Council to explore a wide range of options. for the area and that public views were thoroughly canvassed.

In my opinion, the selection process has been open, public, transparent and fair. Throughout the competition it has been consistently and clearly stated that the decision on the winning design was to be made by the Waterfront Development Subcommittee. The Subcommittee actively sought the views of the public through a variety of consultation methods, both formal and informal. It also drew upon the advice of a range of experts, including the Technical Advisory Group (TAG) and Lambton Harbour Management Limited (LHML). The reports and record of this consultation and advice is extensive and was thoroughly reviewed and assimilated by each member of the Subcommittee.

It was clearly noted throughout Stage 2 of the competition that the formal and informal research on public opinion would be an important part of the information to be considered by the Waterfront Development Subcommittee. And so it proved. However, the public consultation process was never represented as a vote or a referendum.

Your summary of the results of the consultation is correct, although you have omitted the interest and user group feedback. This showed, in particular, different levels of support for Schemes A and D, some of it quite polarised. This feedback included comment from several professional bodies who preferred Scheme A.

It was unfortunate you were unable to attend the meeting of 25 November. Nevertheless, you will be aware that the information provided on all the public consultation and submissions, and the reports from TAG and LHML were scrutinised and discussed in great detail by the Subcommittee. I note the specific criticisms you make of the TAG and LHML reports and can assure you that the Subcommittee sought clarification on many of the issues you raise as part of the questioning of WCC officials and TAG and LHML members at the meeting.

I am confident that the Waterfront Development Subcommittee, in its five hour public deliberation of the shortlisted schemes - and in the preceding weeks where members 
spent a great deal of time examining the entries and considering the various relevant reports - made a balanced and responsible decision. As you are aware, debate on the final decision focussed eventually on the merits of Schemes A and D. In my opinion the debate was rigorous, thorough and fair. Scheme A was selected only after the main concerns about certain aspects of it (many arising from the public consultation activities) were identified and deemed resolvable in the next stage

I can understand that you are disappointed with the result, but I do not accept your contention that Scheme D "did not really get a fair go" in the competition. As Chair of the Subcommittee, I undertook to ensure that all contestants got "a fair go". I believe they did. In the end, the decision of the Subcommittee in favour of Scheme A was unanimous.

It will be difficult and no doubt disappointing, for you to know how close you came to winning. I do congratulate you and your team most sincerely on the quality of the work presented. All teams made exceptional efforts to present their designs effectively and persuasively. I understand the Mayor intends to thank all contestants for the efforts they each have made on behalf of the city, personally at a function in January. Wellington is fortunate and privileged to have had the opportunity to explore and choose from a wonderfully diverse and imaginative range of design options for this challenging site. You contribution has been significant and is acknowledged.

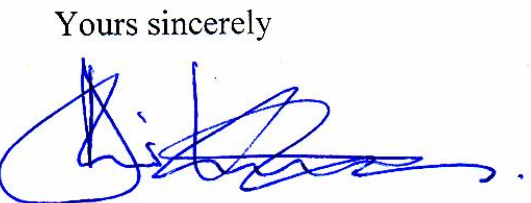

David Kernohan

Chair, Waterfront Development Subcommittee

In this letter of response, the Chair of the Waterfront Development Subcommittee, David Kernohan, makes no attempt to set up a meeting with Rachel in order to talk things through, a step that would have indicated her concerns were being taken seriously. Instead, she is given a polite brush off and told everything is in order, this being the sort of response lobby groups were well familiar with. [Lindsay Shelton found the prospect of having to engage Council in one legal battle after another a wearying one, which may have contributed to his decision to step down as President of Waterfront Watch after some nine years of involvement. Mary Varnham's group, 'Chaffers Park - Make It Happen', wound down its operations following the competition, having achieved its goal of a park on the site.] 
If anything, the task of lobby groups was becoming increasingly difficult, with former Chairman of Wellington Civic Trust, Ian Hunter, commenting on the problem of keeping abreast of waterfront developments:

'One of the features of many of these issues is that they have become more technically and legally complex. Without specialist knowledge relating to the Resource Management Act, urban design and planning, architecture and environmental matters it is becoming more difficult for community groups like the Trust to participate in both the consultation and decisionmaking process.'

(Wellington Civic Trust newsletter, Annual General Meeting, 23 May 1999)

'This has significant implications for all of us, yet the way material has been presented means that unless you have considerable knowledge of the subject it would be extremely difficult to make a submission that would carry any weight. It could well be that the whole process will become a debate between professionals who have their own causes to advance and that the interests of the wider community will get submerged in esoteric wrangling.' (Wellington Civic Trust newsletter, December 1998)

The Wellington Civic Trust, and its Trustees, had a long and distinguished history of working with the Council in a co-operative, and more conciliatory, way though they were not sparing with their criticism when necessary. It was just done in a less abrasive way than Waterfront Watch. This meant that the Trust's profile was more subdued, which detracted somewhat from the considerable work it had done in relation to the waterfront over more years than other lobby groups. Ian Hunter may have recognised that the ability of lobbyists to act as actual, and potential, catalysts was about to come under threat owing to the increased size of development projects, making involvement in decisionmaking a more fraught business. The question of how to keep the channels of communication open with local authorities, while pressing for a greater stake in decisionmaking processes required tact and diplomacy.

Resorting to legal appeals, 'faute de mieux', was a position that was hard to sustain on a number of levels. The cost in time and energy took its toll on lobby group members, with bad experiences capable of affecting morale. This brought into question the viability of litigious models of interaction for resolving ongoing differences. Institutional frameworks were likely to change as a result of continued challenges, possibly backfiring on all concerned. The public, for whom these battles were presumably being fought, are mostly oblivious to this rivalry, being the last to know and often care what is going on behind the scenes. Yet this inability on the part of rival interests to accommodate each other, which is all too evident in Wellington's waterfront redevelopment, demonstrates how attempts were made to eliminate opponents on both sides of the debate. Moreover, because the system that created this hostility stemmed back over several decades, this made it hard not only to identify where the problem began, but more importantly where best to begin rooting it out. After simmering away for years, even the smallest trigger 
was now sufficient to make the conflict erupt again, with a strength that surprised everyone.

This shows that land-use problems are part of an ongoing process, with fights over public land being no different to those occurring over privately held land except that they are played out in fuller view of the community and involve more people. When the battles get nasty and turn personal, then hope gives way to disappointment and disillusionment, making it an unpleasant experience all round. The waterfront project begins to embody both good and bad aspects of relating, showing it to be anything but a static entity since no two people seem to share the same opinion about its worth. The same goes for Waitangi Park, whose meaning vacillates according to who is being addressed with some loving it while for others it holds old unhappy memories. Whether Council imposed its vision for this site on the public, or simply made a hard decision where no consensus could be reached, remains unclear; readers must judge for themselves. Certainly Bristol's experience of its waterfront redevelopment rings familiar, indicating that Wellington's situation is not all that unique, a thought that is at once comforting and depressing. Waitangi Park begins to look less of a prize and more of a threat in realising that it symbolizes the tension between founding and preservation. This explains why, for a brief time, this new park was the focus of so much attention. Whether it is destined to become a loved place, or a space people are mostly indifferent to, is equally hard to predict.

This makes an urban park a queer object that comes about as a result of a deliberate political act to keep a site not only public, but clear of buildings. The conscious decision not to allow anything, other than recreational facilities, to prevail on a site is therefore uncommon, land being especially at a premium on desirable waterfronts. Since creating a park requires a great deal of planning, consultation, and money, these types of amenities represent a combination of components rife with potential possibilities and problems. So in studying a park and asking why it has been envisioned in one particular way rather than another, a host of questions arise. The manner in which a piece of land is employed tells us who its real owner is, with the contest in Waitangi Park's case being between Wellington City Council, lobby groups, and the public. When a supposedly open competition gets thrown into the mix, then it becomes an extension of its owners' will and employed as a tool. The sponsor maintains its right to select a winner, this being whoever devises a design that best fits the needs of the owner, as stipulated by technical experts employed to make sure pre-set requirements are met.

Taking these facts and forcing them into confrontation with speculation brings the reader into contact with the sociologist's perspective, where a different kind of knowledge is made possible through a more abstract take on events. Here Waitangi Park is looked at in three new ways: as a presence, as a place of transformation, and as a space of obliviousness. From this unfettered position it becomes possible to detect absences and give them presence, though it requires the reader crossing over into unfamiliar territory. In going back over the site's transformation from a busy port to an obsolete facility, we witness it being bandied about by fate and vested interests, almost disappearing as an entity for a time only to resurface as a cultural park after a prolonged battle. 


\title{
Foreground
}

\author{
In taking up the foreground position, \\ the principle object of an inquiry \\ becomes visible. Being the most \\ conspicuous and active of stances, a \\ defter rendering of accounts is \\ required.
}




\section{Foreground}

In turning away from Waitangi Park as we have come to know it, and in re-envisioning the site in a more speculative way, significant absences come into view.

\section{Waitangi Park as a presence}

If a state of presence means being in front and can be used with a vague sense of place, or space, then what sort of presence is a park? We know that people with presence are supposed to be impressive in appearance and bearing, with some aspect of them standing out as stately that makes them a strong influence on others. There has to be a presence not only of body but of mind as well, with a sense of the person in question being endowed with selfcommand in difficult situations. These

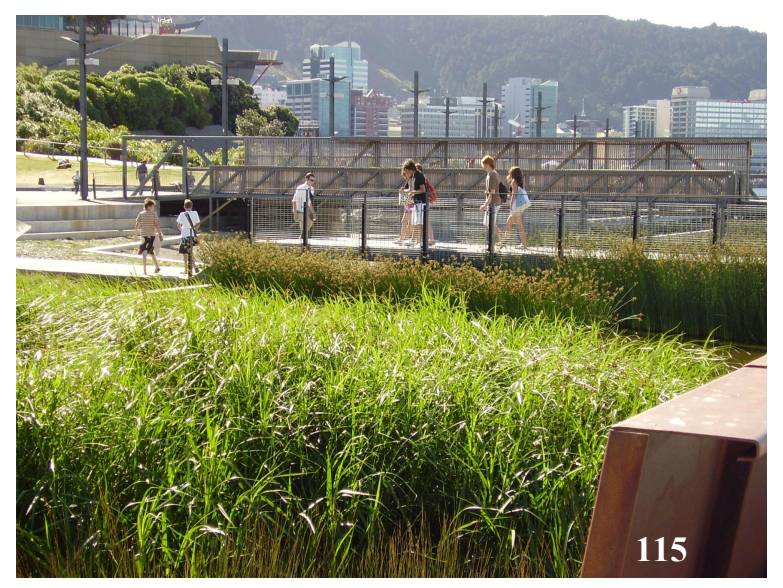
sorts of individuals are said to be free from any sort of embarrassment, or panic, lending them additional character. But if these same traits are applied to an object like a park, what would it need? Is Waitangi Park, for instance, considered a presence or merely a green, open space?

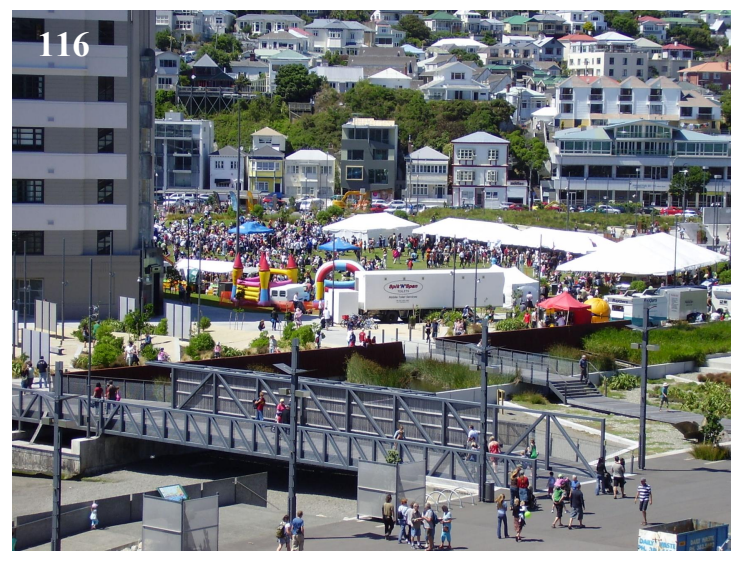

So for a park to retain presence, its users have to feel engaged with the space on an ongoing basis; there also has to be a groundswell of emotion, or some sort of significant movement, around the site in order for it to be seen as distinct from any other place. A great deal depends, then, on whether a park's potential has been fulfilled to its utmost.
To discover whether an object radiates presence, a simple question must be asked; what would it take for Waitangi Park to no longer have a bearing in a person's life? Some maintain that when a park is no longer part and parcel of an active process, then it lacks any kind of presence. That when its administrators fail to stay alert to the needs of the public, then any chance of creating a memorable presence is erased, or at the very least diminished.

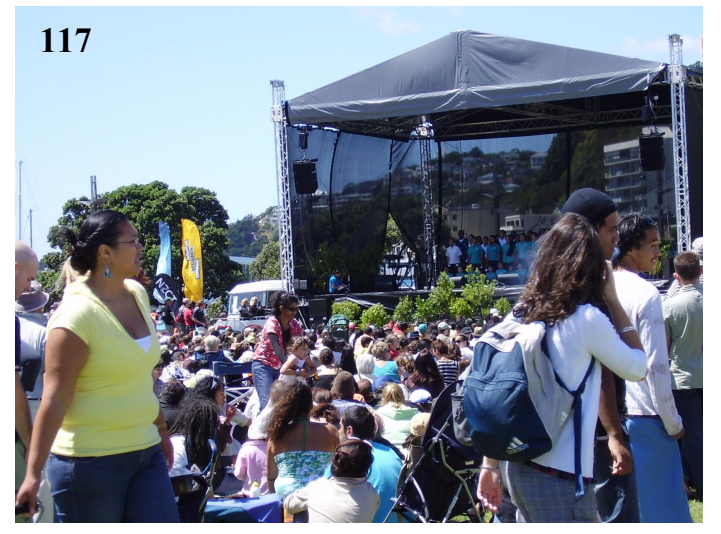




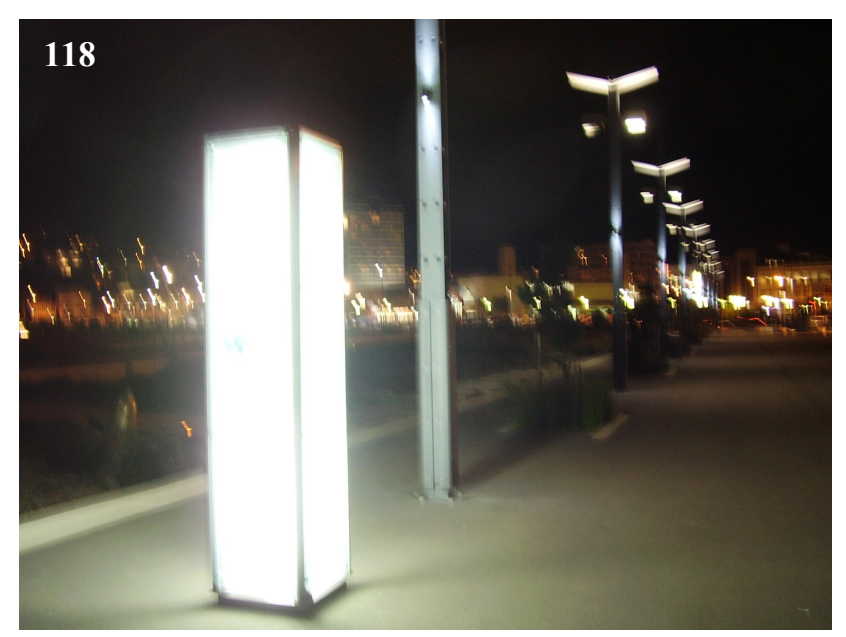

One way of attaining presence is for an interchange to take place in the form of a magical connection, or synthesis, where act, place and word come together. This makes presence something akin to shared imagination where staying in the present, or inside the moment, was all important. When people remain fully aware and alive to a place then a moment of coalescence happens between a park and its users, making for happy coexistence. The unconscious power of presence is at work in these instances, unleashing a certain freedom and truth. If the choice is made to let this presence come along with us, and we decide to play with it and enjoy what is on offer, then the park's mission is fulfilled and the site is complete; contact has been made.

But if a park experience turns out to be unsatisfactory, and found wanting in some discernable way, then clearly something is amiss. When absences make their presence felt, it forces unhappy people to take stock of their assumptions and expectations about a park space. These absences become a presence, glimpsed only through a scrutiny of what has been dismissed.
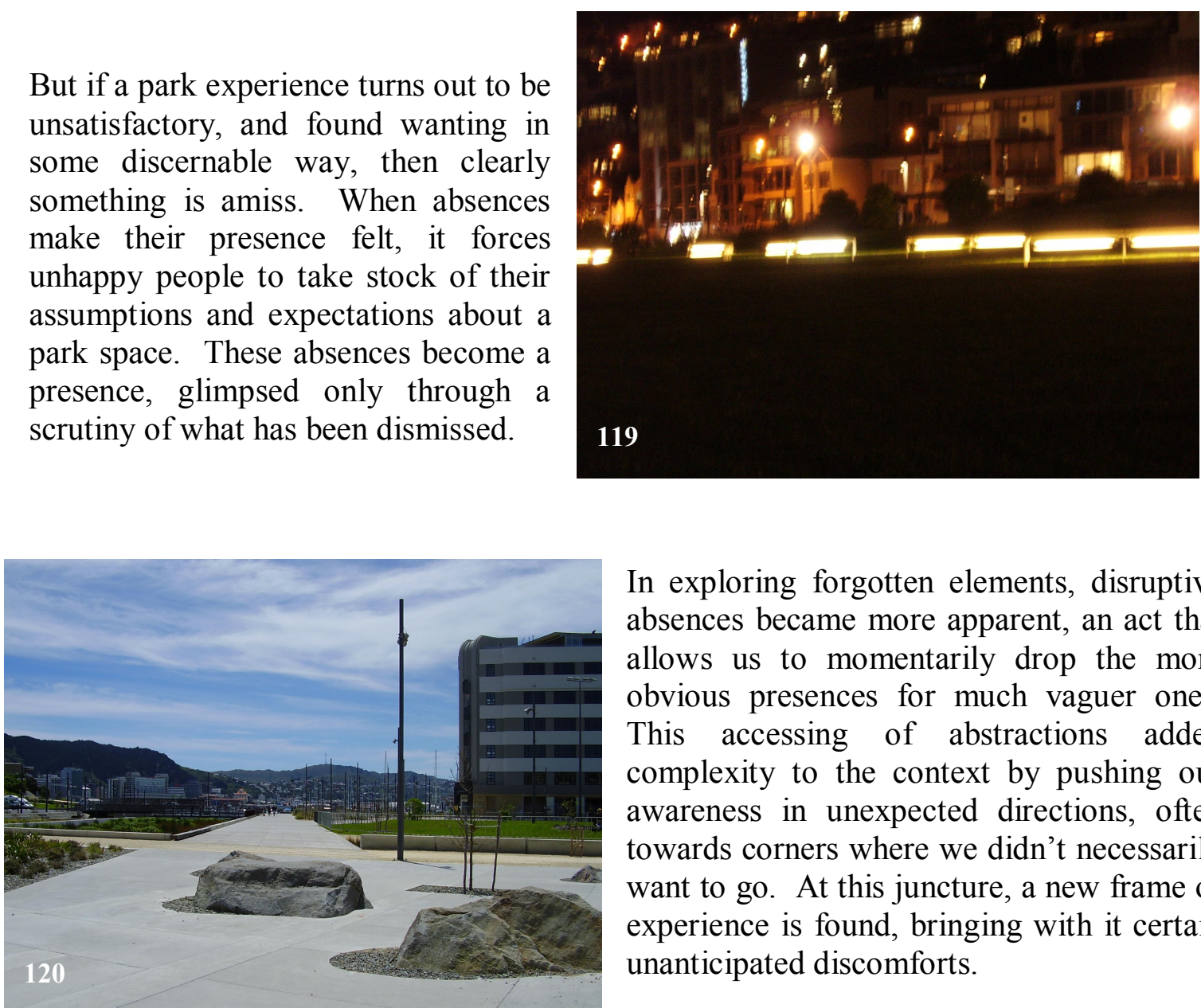

In exploring forgotten elements, disruptive absences became more apparent, an act that allows us to momentarily drop the more obvious presences for much vaguer ones. This accessing of abstractions added complexity to the context by pushing our awareness in unexpected directions, often towards corners where we didn't necessarily want to go. At this juncture, a new frame of experience is found, bringing with it certain unanticipated discomforts. 


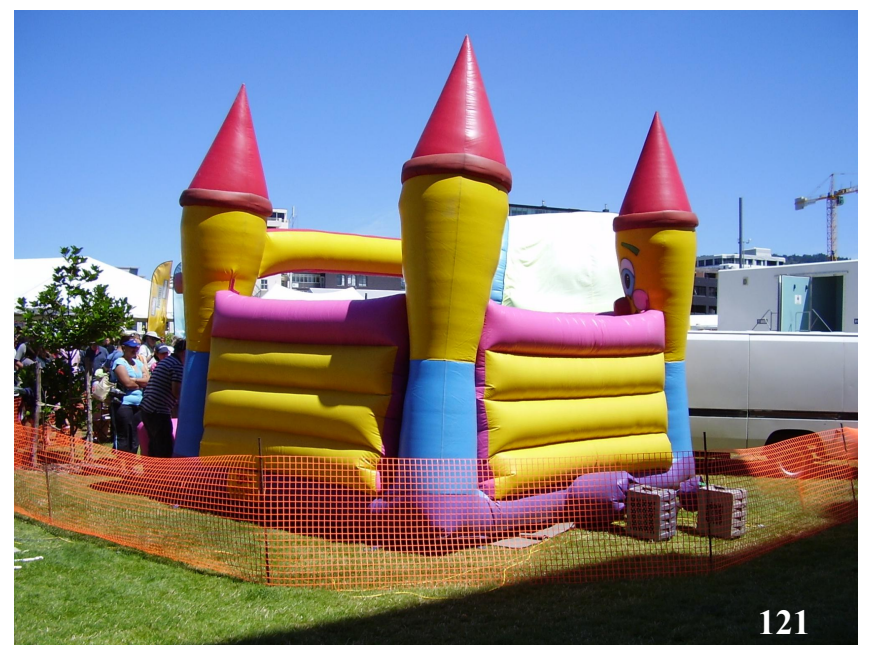

At times like this, the park goes from a benign presence to something less than welcoming, the familiar suddenly becoming unfamiliar, even a little sinister in light of newfound awareness. This raises an ugly thought: whether a real transformation could ever be expected to take place in a space like this, or if the park isn't just some awful manifestation of a great grinding machine let loose to capture ideas and pulverise them.

From this perspective, the park no longer looks the type of place to call 'our own', the perception of the site having been transformed with too much unpleasant foreknowledge. An ugly spectre rears its head in allowing another version of Waitangi Park's creation to re-emerge, one revealing a less than sunny landscape.

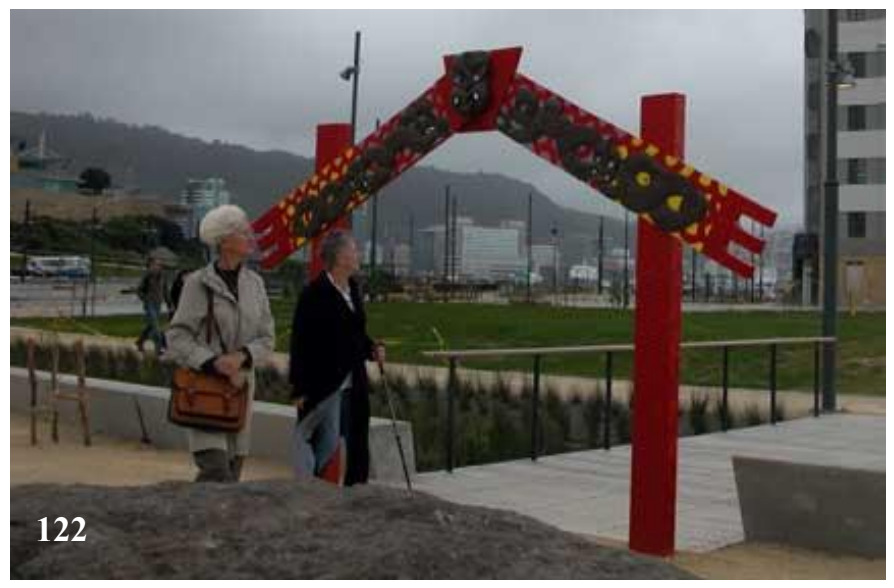

A reconsideration of facts must be undertaken, however tedious and distasteful. As more and more ingredients get added to the mix contradictions pile up, weighing down the

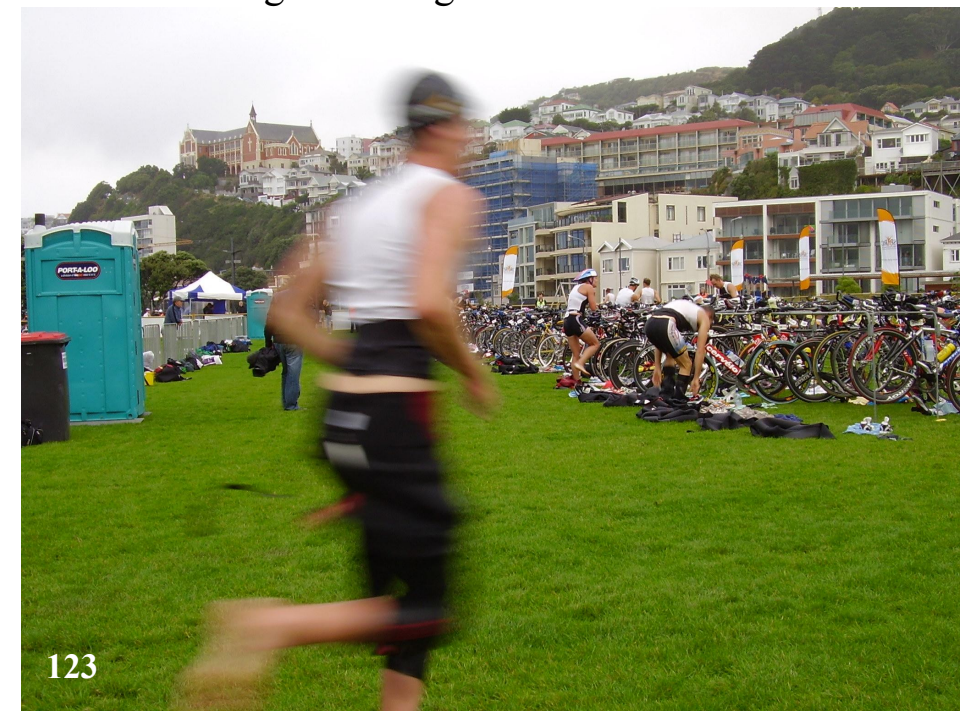
exercise almost to the point of stalling. Accounts multiply until a state of confusion is reached where efforts to arrange, and rearrange, these stories expose livid gaps and heretofore invisible boundaries. These lines of demarcation are telling, in that they allow those witnessing events to extend their gaze across not only seen features but unseen ones as well. What had been taken away now gets superimposed. 


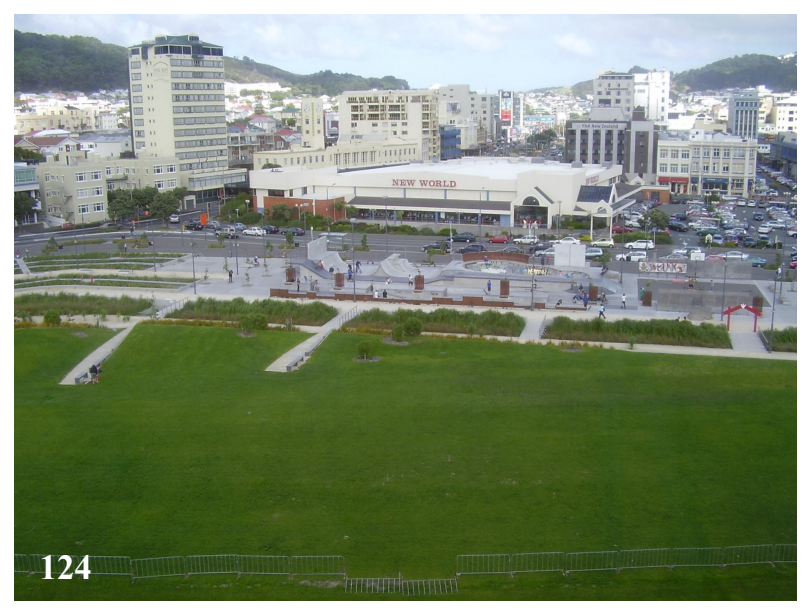

The balance is being tipped with behind the scene motives set aside for a while. The disunity caused by so many accounts, and interpretations, has made the journey a tiresome one that threatened to go on 'ad infinitum'. The stories, becoming garbled in the telling, retain a particular quality of energy in spite of this chaotic context. The 'good' and 'bad' of the place have been uncovered, making the park experience richer.

In permitting the storytelling process to overtake the reader, odd angles and crazy patterns come to replace what at first appeared unnaturally harmonious and smooth surfaces. The prescribed homogeneity of the park's design is shattered by the action of digging around in its past. Following along as events unfold makes us aware that most of the choosing has been done by others, the task having been left to them in good faith. It all looks so locked down, in hindsight.
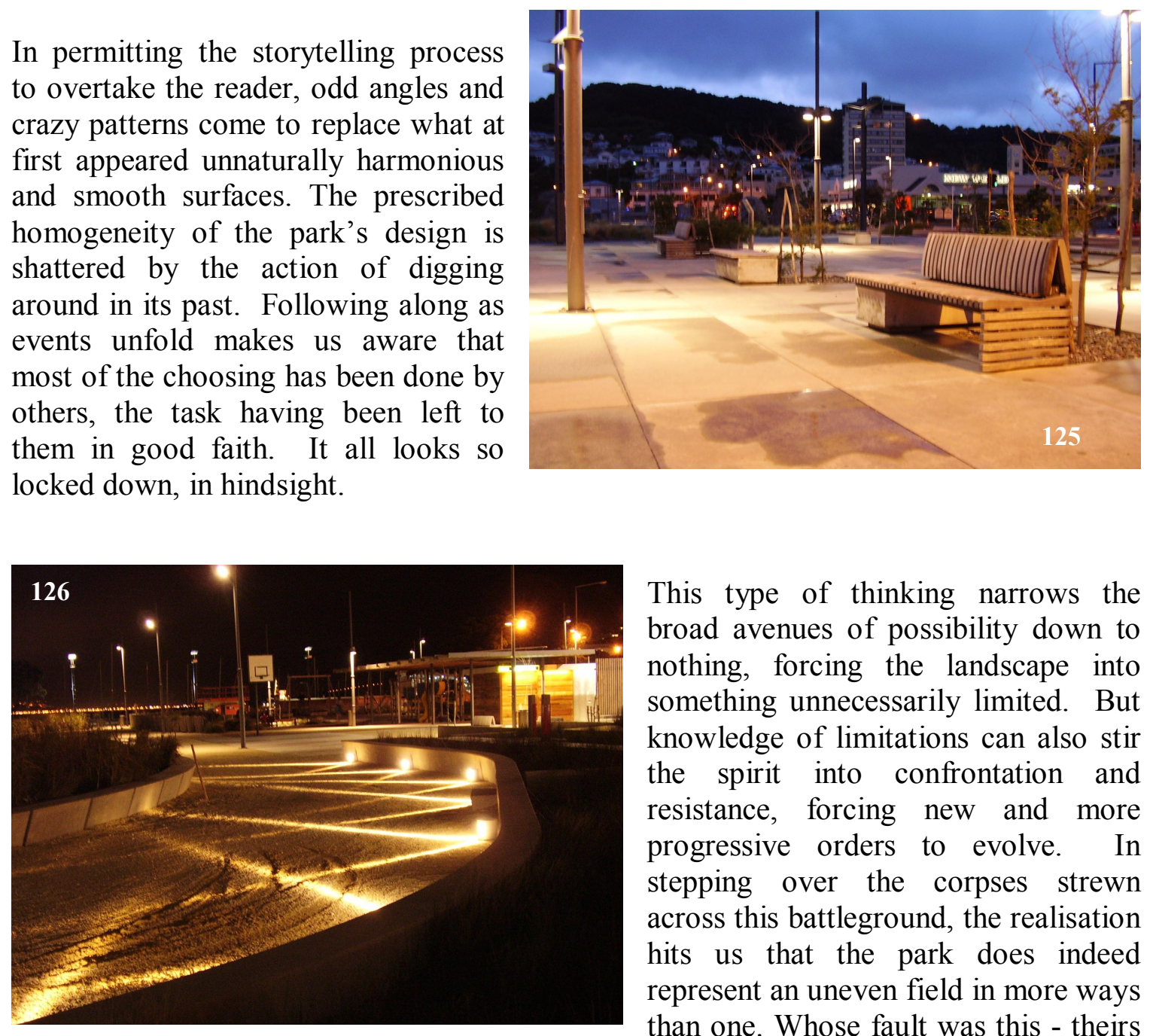

This type of thinking narrows the broad avenues of possibility down to nothing, forcing the landscape into something unnecessarily limited. But knowledge of limitations can also stir the spirit into confrontation and resistance, forcing new and more progressive orders to evolve. In stepping over the corpses strewn across this battleground, the realisation hits us that the park does indeed represent an uneven field in more ways than one. Whose fault was this - theirs or somehow ours? Are we complicit in some way for how things turned out, and if so in what way? No longer slaves to objective facts, a measure of discernment is now possible, signaling the return of choice. 


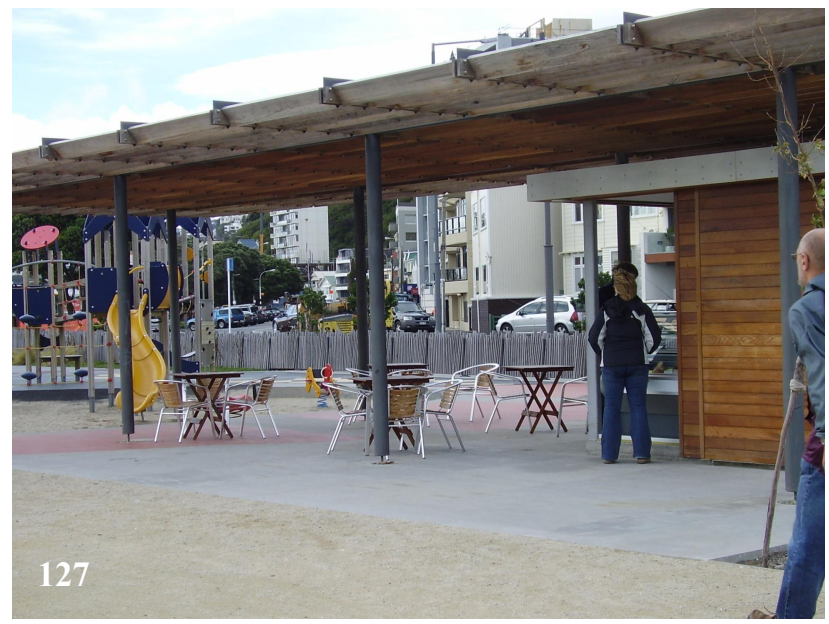

difficult quest, and after much consideration.
We understand now that the park is a place of process, having learned to discern what is needed and what can safely be discarded. In separating out what warrants retention from obfuscating details, the brute impact of disillusionment is tempered somewhat. This exploration of a public place has cost us dearly in some ways, the relocation of missing elements having exacted quite a price in terms of lost innocence. This sort of insight only ever materialises towards the end of a

From this interplay of act and place came new insights and skills of discernment, such as the ability to pause when required and record faithfully what is transpiring according to close observation. This approach represented not so much an evolution in seeing, but a revolution in perception. Only in examining the position of facts in the context of experience did it become clear that imposed forms filter out chaos. For the sake of structure, many events and objects are buried, pushed out of

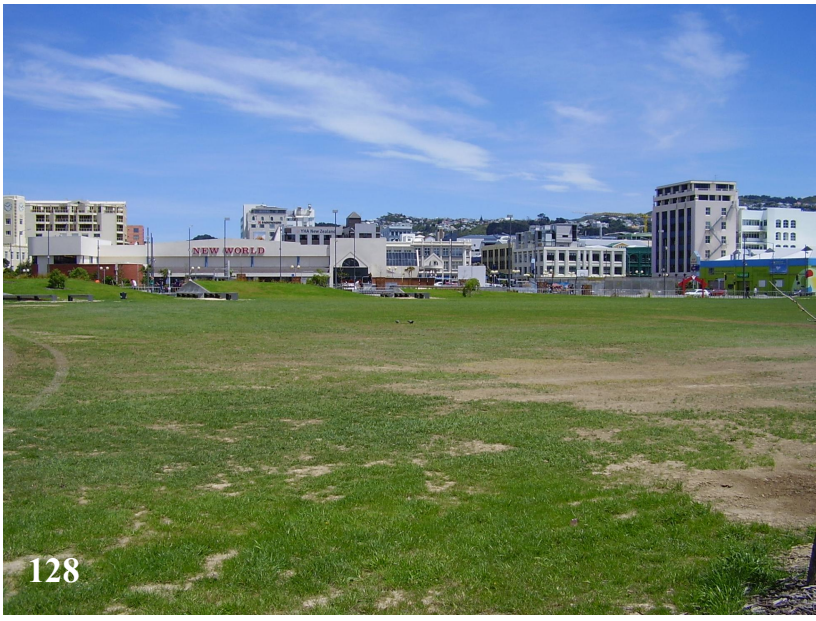
sight by the sheer weight of other's intentions. It has taken an outsider's eye to discover this alternate view of Waitangi Park, where in testing what is there against what might have been, an altogether different perspective on this open, green space becomes possible.

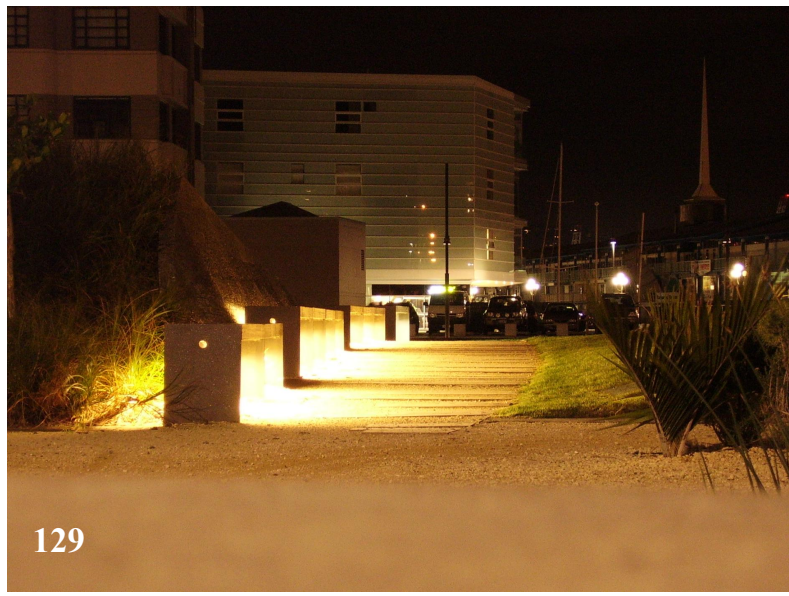

The assumption that every story has two sides is a false one, the truth being that most have multiple versions and angles from which to choose. Weaker versions are lost with time while the more robust ones get bought and paid for, going from strength to strength with every retelling. There is more fragmentation and reversal on the horizon, suggesting that Waitangi Park's story is as yet incomplete. 


\section{Waitangi Park as a place of transformation}

Transformation, from one state to another, becomes apparent mostly through destructive activity, the observer but rarely getting an all-encompassing view of the process in its entirety. Nor is there any consciousness, on our parts, of the role we play in bringing about this change.

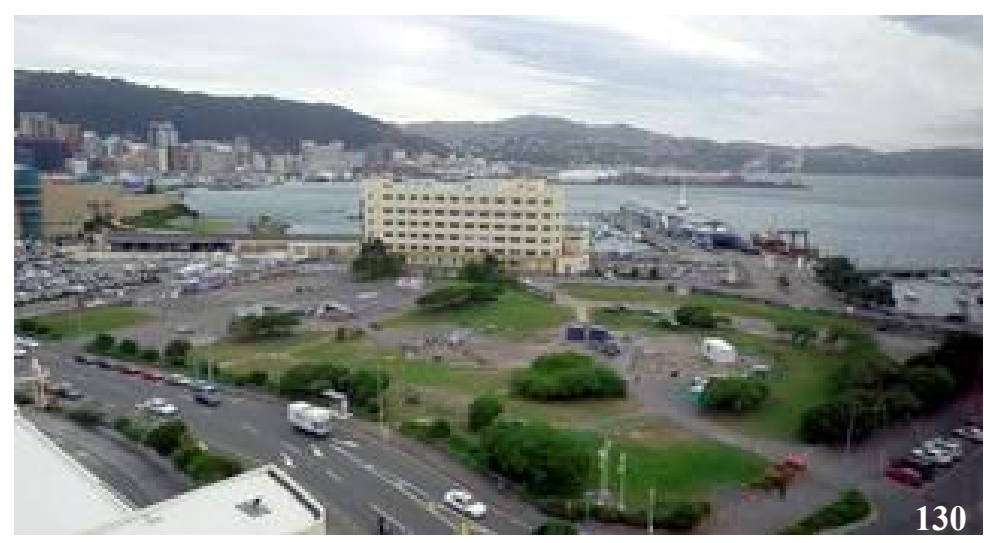

Only once a place has begun its transformation does the onlooker take notice and then, usually, only in passing, yet every moment of a transformation brings about alterations from the initial whisperings all the way through to a project's completion. The scenario is almost always the same, with the old making way for the new. In considering the old Chaffers Park pictured above, there is a certain scruffy harmony to the site beneath whose provisional surface, countless other transformations have taken place - now long since forgotten.

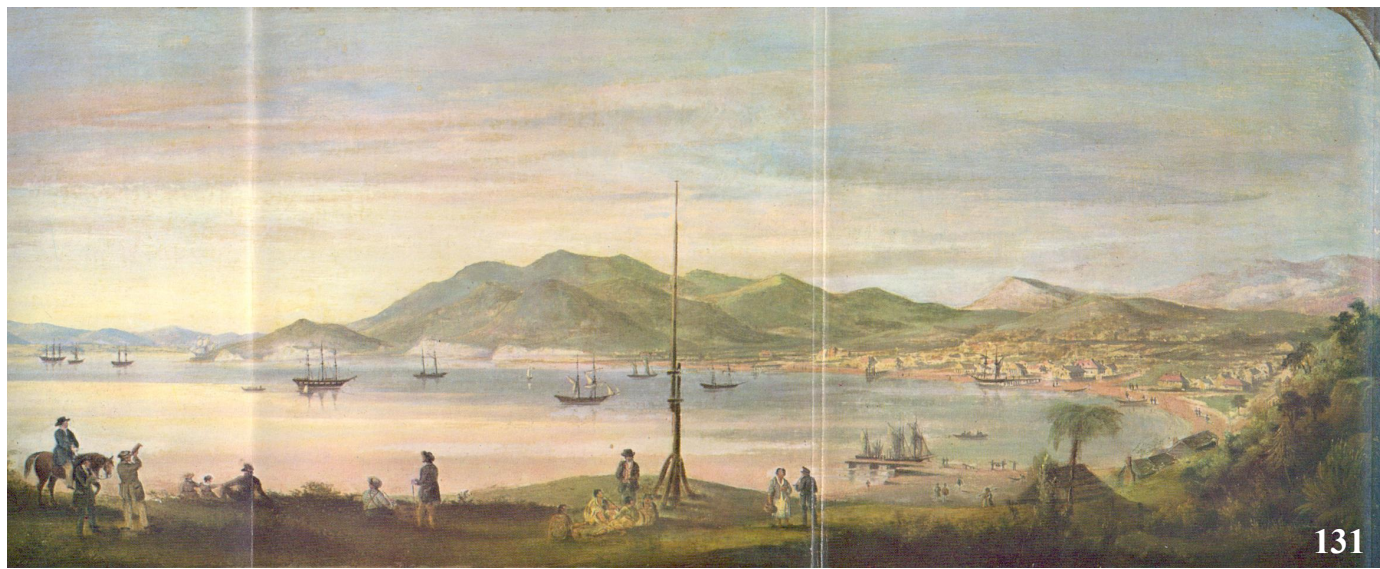

An unspoiled bay remade a thousand times over, with so many alterations to its name that the place is barely unrecognised as itself. An earthquake has pushed the site up by a metre or more, and redefined the area forever by opening up possibilities for new growth

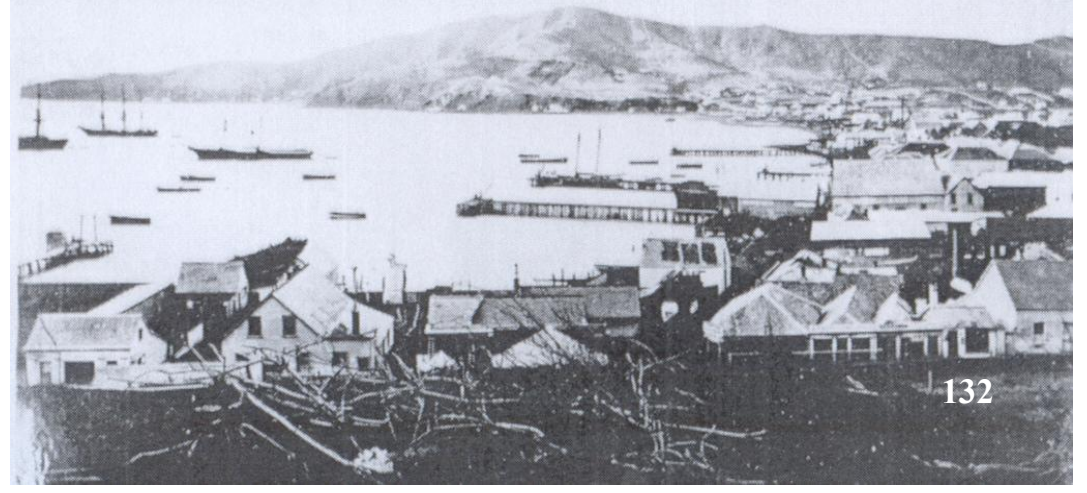

in the process. A bog that regularly breaks its banks, flooding out the eastern end of Port Nicholson, is drained thus changing the landscape yet again. 
Rickety docks are built then torn down for more substantial port facilities, leaving private owners out of pocket, squeezed out in pursuit of greater commercial gain. Wellington City, being bound and bent on survival, only has the one story to tell of growth and potential in the making. Gone now is the sleepy fishing village of yesteryear, replaced by a strident bustle, each year forward bringing gain of one sort or another with never a mention of loss in the narratives. Even sea water is replaced to make way for much-needed services, with the result that a once pristine place is quickly transformed into a desecrated hovel fit only for industrial purposes. People and things come and go in rapid succession, their stories mostly buried beneath tons of brick and rubble. Buildings are put up, seemingly higgledy-piggledy, all for the sake of convenience and gain. Warehouses once prized, soon teeter on

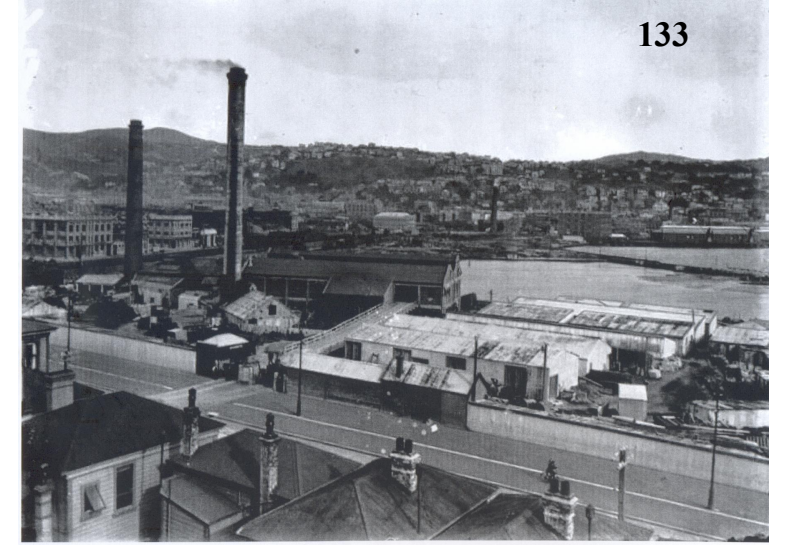
the brink of destruction their worth succumbing to other imperatives and new development pressures. Waterfront train lines, once the pride of a community, are about to vanish, their removal suddenly being just as necessary as it once was to lay tracks.

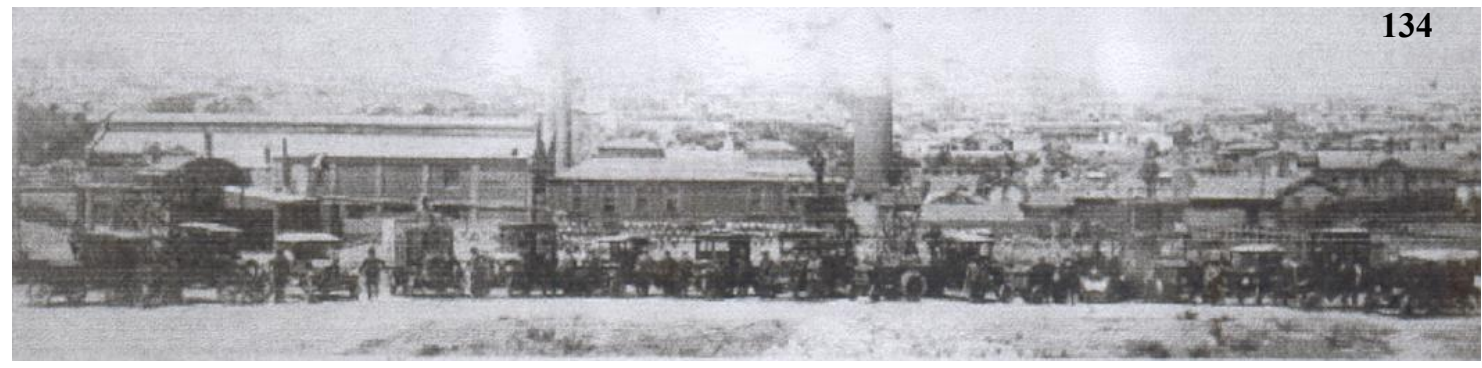

Until the point is reached where nothing of what is pictured here remains, the various sites having long since been obliterated except for the odd surviving building or two. These mementos are a reminder of the sheer pressure of time, and life, on a place.
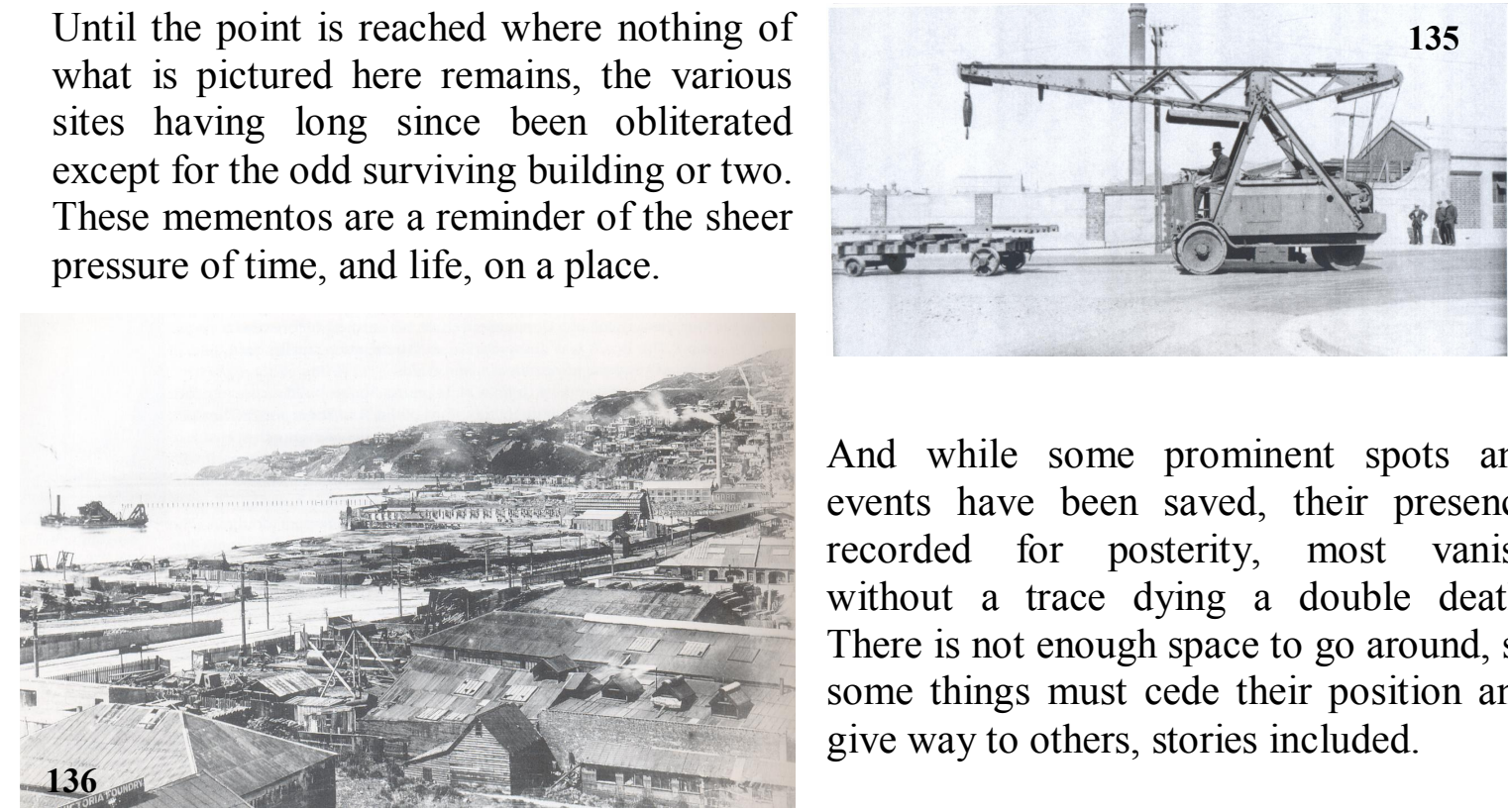

And while some prominent spots and events have been saved, their presence recorded for posterity, most vanish without a trace dying a double death. There is not enough space to go around, so some things must cede their position and give way to others, stories included. 


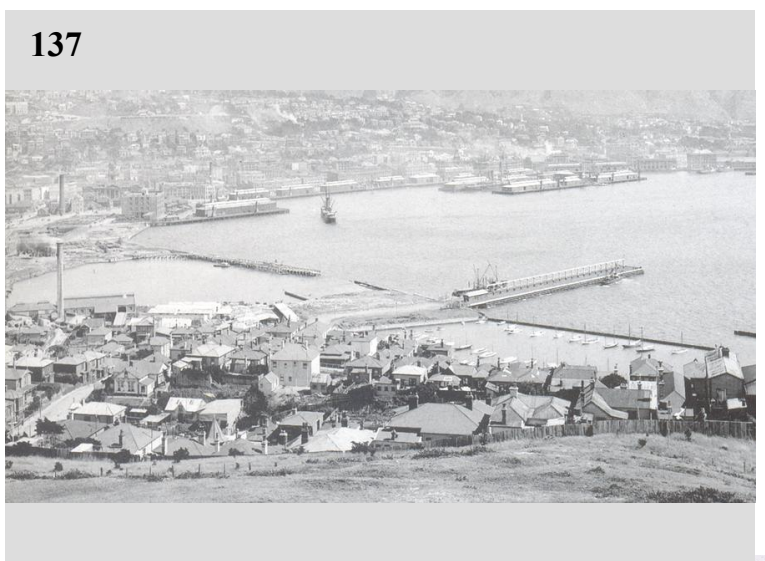

The park idea is hauled out, from time to time, then usually set aside again for various reasons. This type of spectacular transformation being called for requires a lot of money and political will, something the public had little control over.
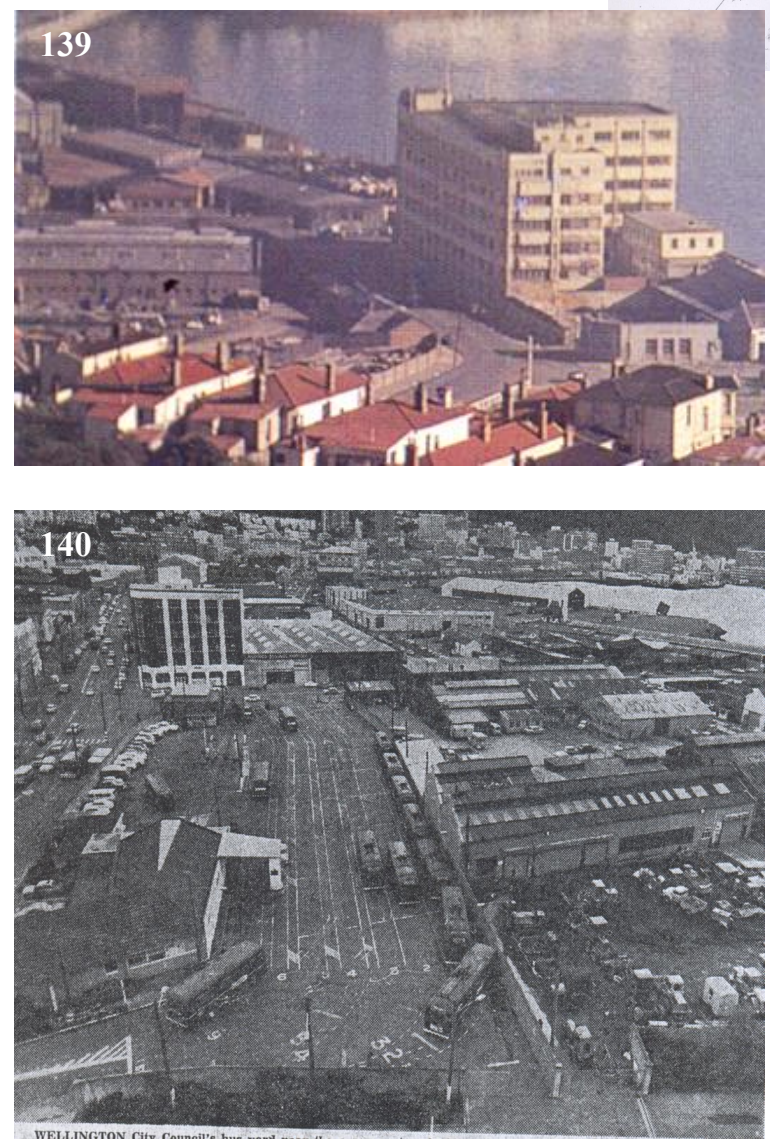

Wellington's port facilities find a good location in Chaffers Bay, and stay there cramming the city's foreshore for decades. Every conceivable city service is also packed into the Corporation Yard, from trams and terminals to God knows what; no corner being left fallow. There is talk of making the site a little tidier, its appearance badly needing sprucing up and the idea of a public park is floated as a way of rectifying the ugliness.

\section{8}

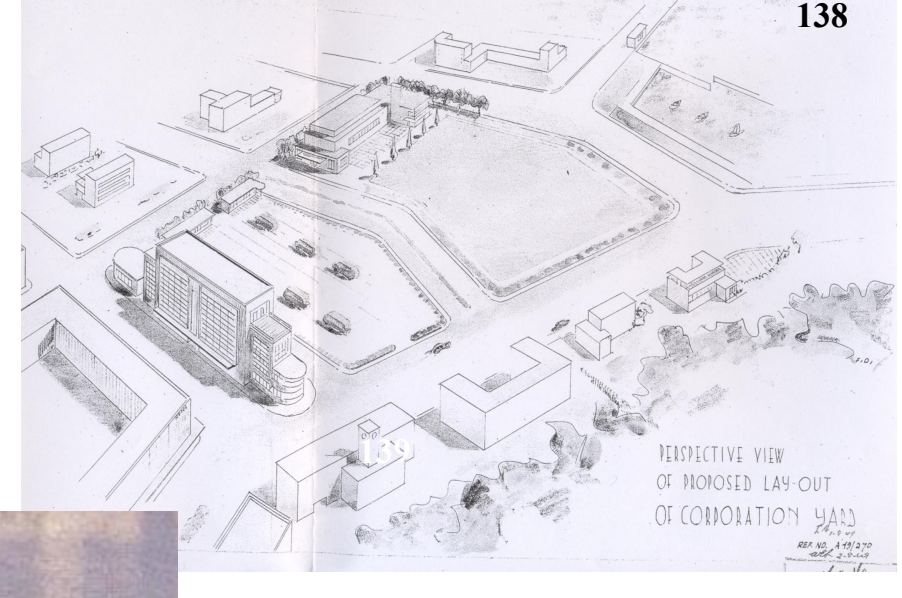

It takes vision and the committed efforts of a City Council to pull off a dramatic change such as turning of a dump into an open, green space. The long-held wishes of a community may not be enough to get things altered in the short term. So the park idea has to wait for another day, until land values rise to the point where transformation becomes profitable, finally prompting Council into action. City Councillors meet and discuss a range of possibilities, deciding eventually to move matters along and have the old make way for the new. Only then does the site's next incarnation come under serious consideration. Replacing an eyesore by sweeping away the redundant is a step in the right direction, though the task would still take some twenty years to accomplish. 


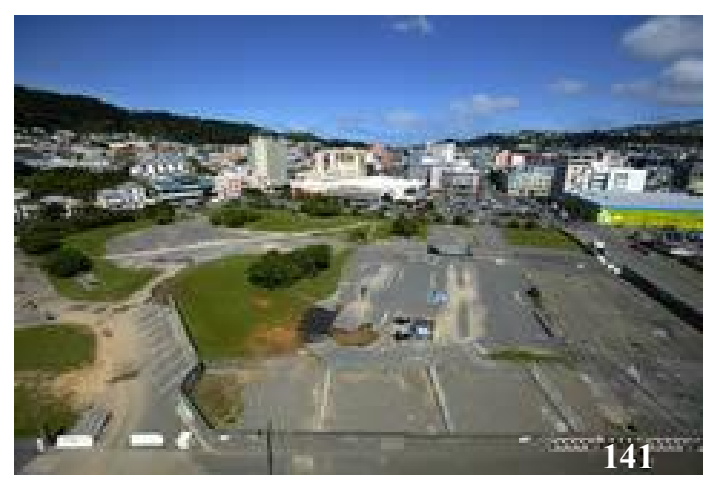

Not like today, when decisions are made in a flash with the finger on fast forward button the whole way through. But the vision for the Chaffers area is uncertain, one minute a park, the next firmly stuck in a holding pattern. Until further notice, the site serves as a rough playground while Council devises some plan or other for it. A goodly sum is spent on making the park passable and though a bit of a mess, the place is popular with its users, mostly young skateboarders who make it their home-away-from home.

Something has to be done about it, though just what that might be is up for grabs with complaints mounting about the inadequacies of the whole area. Misunderstandings are bound to occur, given that plans for a housing estate and retail outlets, along with a pocket sized park, have received Council's consent to be built. The public seems to have gone back on its word, no longer wanting what

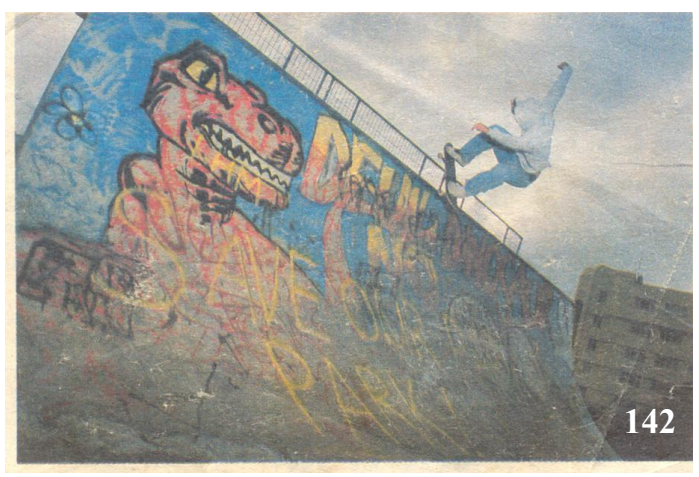
had been suggested by designers in the 1982 competition, preferring the park idea.

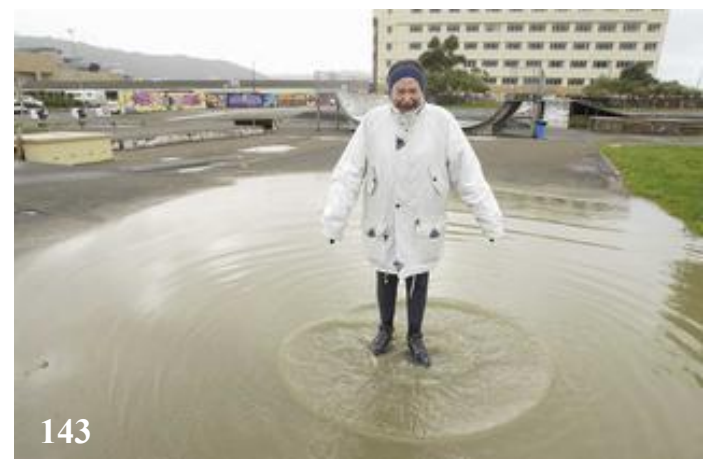

Here is the origin of the debate, where the battle begins over who owns the space and has a right to designate its eventual use. An unwanted transformation is bitterly opposed by the people who want the space kept for public rather than private purposes. The ensuing conflict makes headlines and forces a split, the tussle continuing until Council finally backs down and goes back to an older vision for the waterfront.

This marks a tipping point between the public's and Council's relations, the site's future drawn with a quick bold stroke by the people. Now there will be a park, but what of its design? Will a consensus be reached and a unified vision found, or is another skirmish about to erupt over the competition?

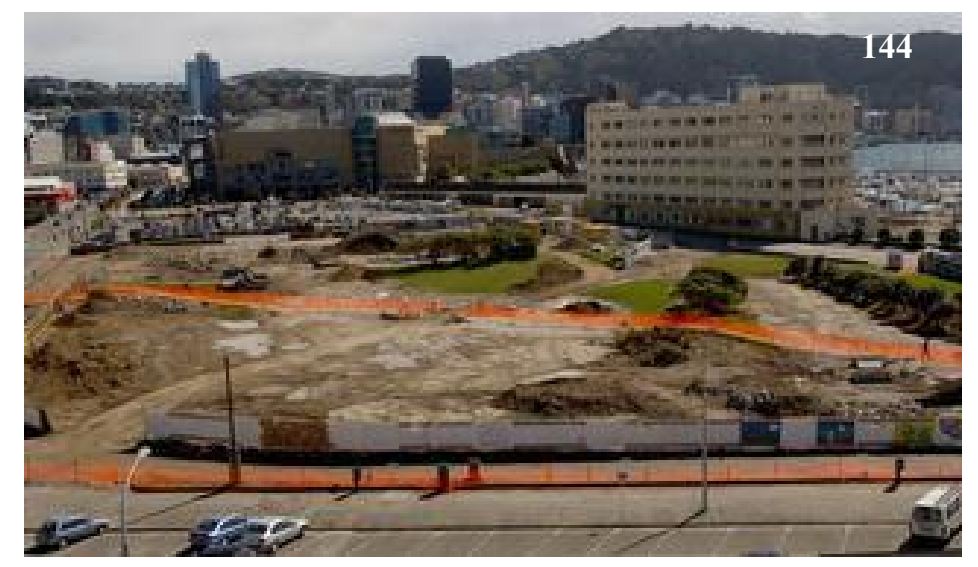




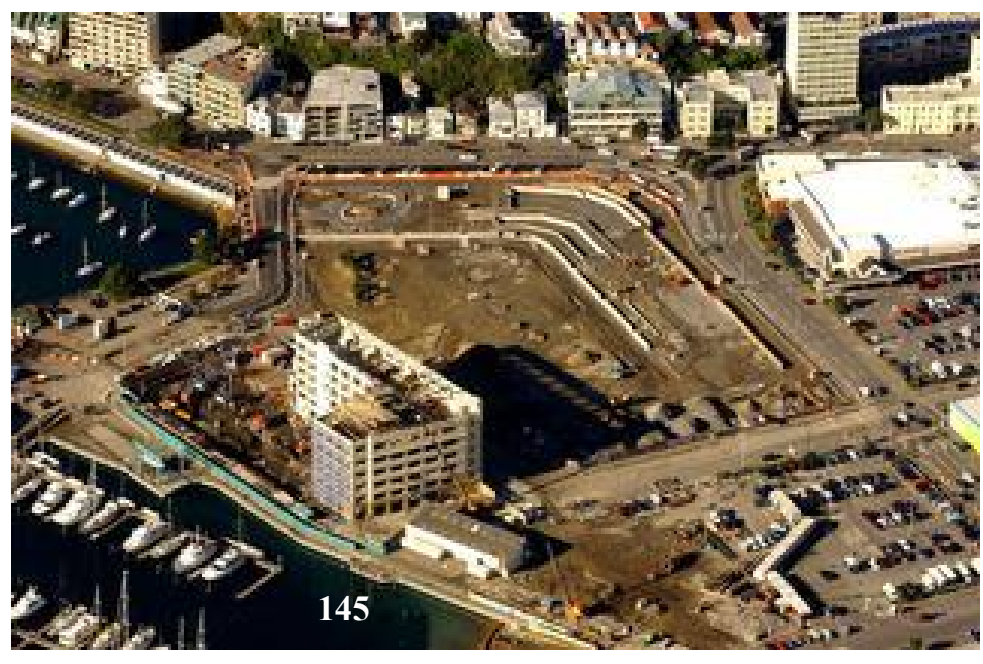

Problems arise but the antagonism is less pronounced this time, Council having taken the process firmly in hand. The process unfolds according to plan, with a winner finally being selected on merit. Then, scoop by scoop the site begins its remarkable transition from a rag tag open space to polished environment fit for New Zealand's capital. But will

this new park be loved?

Splashy visuals and a big exhibition pass for an opening ceremony, with events coming off without a hitch, opponents having successfully been kept at bay on this proud occasion. Waitangi Park is launched to great fanfare and the people come to marvel at an achievement that so

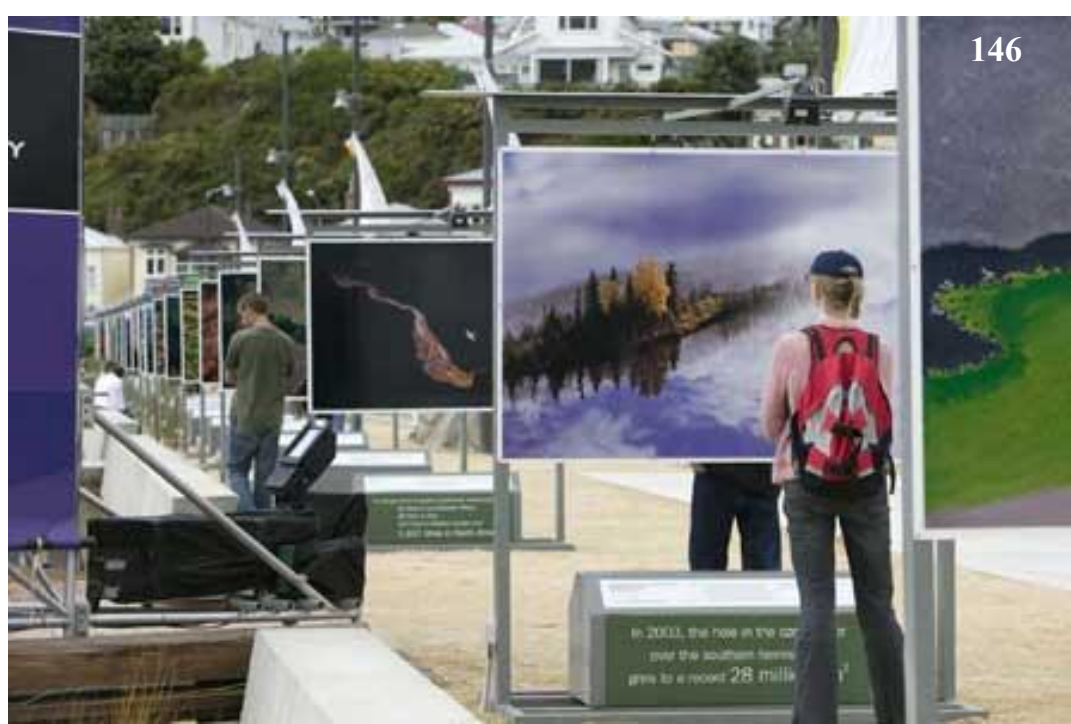
very nearly never took place. The memories are already dimming, the battle having moved on up the harbour. Left behind in the wake of development is a transformed Chaffers area, there to serve as a symbol of fresh beginnings expressing city life and the enjoyment of the present. This park is not intended as a reminder of past failings, certainly not Council's, so although old problems persist, for the moment they can safely be ignored. But grievances and mistrust are not so easily snuffed out, or reversed, being ready to resurface at a moment's notice when the circumstances fit. So could the new park be said to have smoothed out divisions, or merely exacerbated them? Has the vision behind this open, green space been a top-down imposition on the public or the result of a communityled intervention? Have the political responses, both sides of the conflict, been managed or merely left to run their course? Handled differently, how might things have turned out? 


\section{Waitangi Park as a space of obliviousness}

Had another design been selected for Waitangi Park, the people's for instance, then it would have looked quite different from the way it does now. In doing so, perhaps the relations between Council, lobby groups and the public would have been improved, though this is hard to imagine.

If the real intention behind building the park had been to change the principles and values

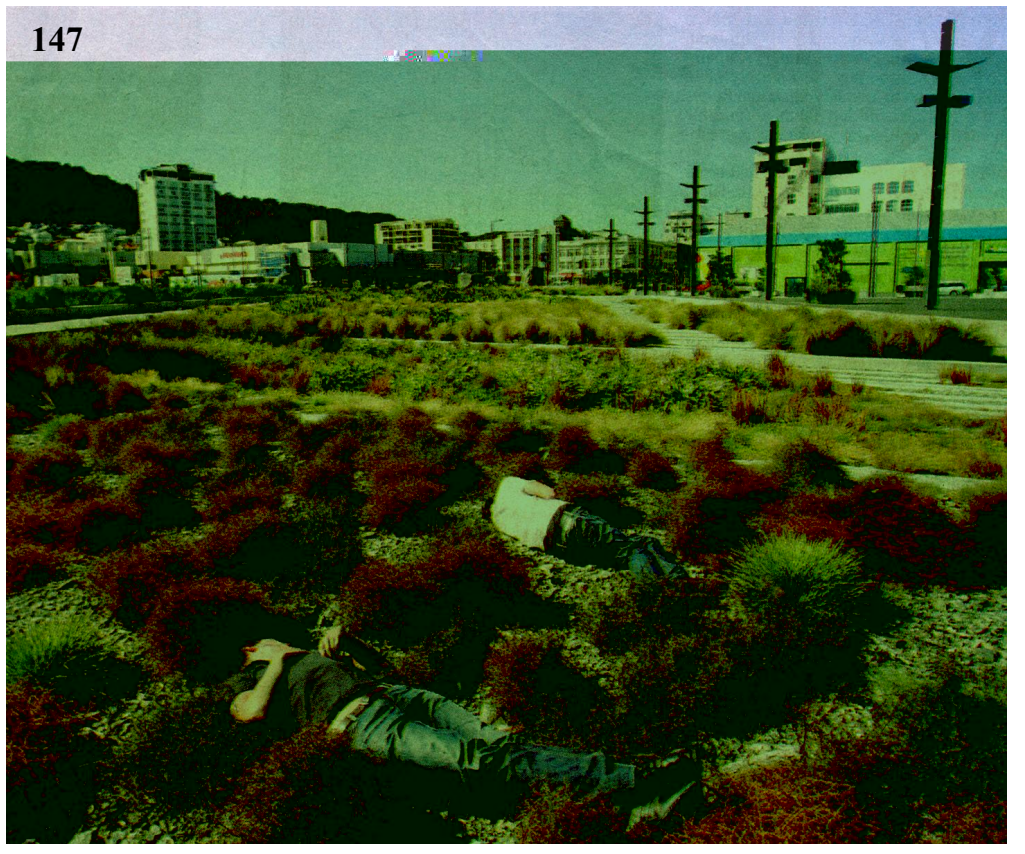
underpinning processes and structures, then a significant transformation in social relations might well have occurred, given sufficient incentive on everyone's part. Bad experiences in place-making might have been replaced by better ones, heralding a fundamental change in the city's future operations. As it stands, the change that took place in the Chaffers area is superficial, being purely cosmetic in nature. This is a demoralising thought, since the design awards and accolades showered on the new park tell us otherwise. We have a right, however, to ask whether the landscape has really been altered for the better through the creation of Waitangi Park. If the outcome of the exercise resulted in more, not less, mistrust and suspicions, then the bad of the place might well outweigh the good, sending us all back to the drawing board for a rethink.

It appears that Council prefers its public to be oblivious to this debate, happy only in the knowledge that a lovely, green space awaits us all along Wellington's beautiful foreshore. This is enough to break our alertness, engender carelessness, and blur all conflicting details that might shake us out of a self-induced sleep. This obliviousness is a two-sided sword though, representing on the one hand a dulling of perceptions and on the other a general disregard for what is going on around us. Whether deliberate, or unconscious, the effect of obliviousness is the same, to smother sensation. In trying to save ourselves from the unpleasant and upsetting, something is lost in the way of empowerment. To endlessly dodge thwarted expectations and knocks to the nervous system, the only recourse is obliviousness in the form of fantasizing, indifference and apathy. Curiously enough, forms of escape like fantasy actually support reality whereas obliviousness provides a magic state of limbo, making it a temporary kind of blindness capable of making a person insensible, and unaware, for a while. 
In a way obliviousness offers obscurity from a too harsh reality, by providing a convenient entry point into nothingness. Unlike the longing of daydreaming, it supplies a rare antidote to wishing, so that its effect is a lot like dreamless sleep. Obliviousness makes life simpler because so little attention is needed, so that it symbolizes a reprieve rather than a platform for attempting 'a movement into new scripts' (Cohen and Taylor 1976:69). As a result, it has the capacity to shield us from an 'interpretive impasse or moment of undecideability' (McQuillan 2001:87) (De Man 1971) by consciously narrowing vision down to what can easily be absorbed and understood. The use of obliviousness is also a convenient way of allowing relationships to break down for a time, so that they might safely be taken up at a later date and reconstituted when the mood is more auspicious. In letting this void take place, even encouraging it, a greater appreciation for others is sometimes possible, thus permitting relations to recover where a serious conflict has taken place. Falling into obliviousness could therefore be considered a positive move, especially if it was capable of breaking down barriers and dispelling solitude. A society may well need the occasional bout of obliviousness in order to function effectively and maintain mental wellbeing.

It does this by providing some a relief from the grind of life, and giving people a way to forgive through forgetfulness. Becoming mindless is a sensible way of moving forward in certain circumstances, and on occasion a clever way of navigating through particularly difficult terrain that is unfamiliar, or threatening. Effectively, obliviousness serves as a substitute for faith by helping us cope, doing so largely by providing an escape from 'the presence of incommunicable experience' (Augé 2004:85). But obliviousness shouldn't be confused with ignorance which stems from a lack of awareness and can be easily addressed if wanted, or with indifference which represents an absence of interest. Indifference is a state of mind where there is no inclination for, or against, something with no distinction made between the two. For the indifferent, conflicts are of no importance whatsoever because in this mental state people don't care one way or the other what happens. All zeal and attention leaves them, the will having departed for parts unknown, a situation that actually renders them unbiased because they exhibit no preference whatsoever. Here, there is no definite inclination, with the indifferent being easily persuaded to go either way in a decision since one course of action is just as good as any other.

To be apathetic requires a certain indolence, the result being a passionless and sluggish sort of person but with an exceptionally tranquil life. This is because apathy causes less bother than engagement or resistance which explains why the apathetic have a propensity for letting events take their own course. By choosing not to intervene in a situation unwanted excitement is avoided, all of which suggests that action is considered an anathema to the apathetic because it leads to commotion of one sort or another. So, in remaining oblivious to certain facts and events, either through distraction, ignorance, or apathy, a person is freed up for other perhaps more profitable activities. They needn't end up wasting their time battling contentious situations, or trying to reverse stalemates once they occur because the oblivious choose to stay unaware. Questions aren't asked and answers sought, the behind the scene goings on staying just that - out of sight and mind - where they are far less troublesome. 
The oblivious certainly don't spend a lot of time considering the impact of design competitions on social vision and political response, nor do they go about digging up old and contentious stories that put a local Council's structures and processes in a bad light. By being blind to all forms of anomalies, no offence is ever taken and need never be addressed or resolved, so the problems vanish. This has the effect of making the oblivious look like they are in collusion with the powers that be. Collusion has a nasty ring to it because it infers willful and deliberate ignorance of wrongdoing, where a person is willing to look the other way for convenience sake. But it can also be used to good effect as a coping strategy, the only risk being that it might eventually develop into an unconscious habit that is much harder to rationalise and justify in the face of real evil. This idea of slipping in and out of consciousness, with the intention of ignoring, takes place more often than we would like to admit. Indeed, the shutting of one's eyes to a recurrent, and seemingly intractable problem, is all too common in everyday life. So in some instances, obliviousness has less to do with innocence, or forgetfulness, than it does with practices of collusion. It goes well beyond a moment's carelessness, keeping troubles at a distance, or even holding problems temporarily at bay, because it allows the matter to be taken out of an individual's hands, and conscience, and placed in someone else's. And it is this willingness, nay eagerness, to pass over difficult decisions to others, ones we ought to be making for ourselves, that marks both the beginning and end of trust. Not surprising, then, that conflicts should emerge and mistrust become rife, especially when expectations are rebuffed and stay unmet. The upshot is worth reiterating, if for no other reason than to hammer home the point lest we forget or become careless once again. How:

'Conflicts tend to cast long shadows on the polities in which they occur. Public officeholders face pressures from the media, the public, legislatures and sometimes the courts to recount how a crisis could have occurred, to account for their response, and to explain how they propose to deal with its impact. When the crisis in question is widely held to have been unforeseeable and uncontrollable, the amount of explaining and excusing they have to do is limited. But when there is a widespread perception that the threat could have been foreseen and possibly avoided altogether, or that the official response after its occurrence was substandard, political leaders and officials may end up in troubled waters.'

(Boin, McConnell, 'T Hart 2008:4) 


\section{Unfinished Business}

Waitangi Park remains unfinished, with plans for more buildings on the site yet to be thrashed out in the public arena if given a chance. This means that the likelihood of more conflicts in future is fairly high unless some sort of transformation takes place in relations between Council, lobby groups and the general public. If nothing happens to this effect, then the debate can be expected to carry on - ad infinitum - with the latest changes to the Resource Management Act being symptomatic of ongoing power struggles over public land use. The buildings envisioned for the park might go ahead as planned by Council, then again lobby groups may come up with a counter-move that blocks their construction, or stall the process for a time. In the interim, the story of Wellington's waterfront redevelopment goes on, and on, and on, making any attempt at a tidy conclusion pretty much futile.

In dealing with the implications of negative place-making practices on organizational structure, let us imagine that a newly created urban park affords neither peace nor pleasure to a visitor. This being the case, the park literally ceases to exist as a place to go, having nothing of worth to offer. This sort of bad experience is capable of turning a place like Waitangi Park into a non-entity, along with all the principles and values underpinning it because no strong connection results between the space and its visitors. It fails in its primary function, the park's conception of celebration carrying no weight since its presence affords little in the way of attachment, certainly no sense of true ownership. This leads to the real possibility of disengagement in the form of obliviousness, a frame of mind associated with unloved, and unlovable, places. This phenomenon comes about as a result of conflicting visions, with some users attracted to the park while others stay away in droves out of apathy, disinterest, or dislike for it.

When this happens, the steadying influence of open, green spaces becomes an illusion, making the park seem less 'our' place than an embodiment of 'their place', a spot belonging to all those shadowy experts tucked under Council's protective wings. And if, for some reason, this newly created space provides no certainty, or calming repose, but only a fleeting divertissement, then what real good does it have? However good the design, it alone cannot counteract conflicts, or even guarantee attendance at the park ground. So while some see Waitangi Park as a marvelous addition to Wellington's waterfront, others are less enthralled by it as a cultural phenomenon, noticing only its soulless quality and concrete expanses. When the park is avoided because of unpleasant involvements and associations, it runs foul of expectations and has a less than positive effect. Yet, curiously enough, in terms of providing a space for falling into obliviousness, the park excels. Here the business of debates, lack of control, public landuse problems, disappear altogether because nothing is made of them. Only older historical facts about the site, or recent technical feats, are alluded to making events in the near distance 'out of play' as it were. Consequently, the park begins to symbolize our right to blot out difficult engagements processes in favour of more leisurely pursuits and thoughts. Not becoming involved then, or even knowing what is going on, becomes an option that many choose, sometimes because they feel unequal to the task or because 
time is at a premium and the battle ahead too daunting. All sorts of reasons for staying aloof suggest themselves, this disengagement not even requiring any form of manipulation on other's part since we are happy to let go for ourselves. Obliviousness can be achieved anytime, anyplace, and requires no skill whatsoever - only persistence and blindness to conflicting facts. After a while, a certain knack for collusion may be necessary, in order to keep things ticking along smoothly. So this business of allowing oneself a lapse in attention requires some forethought, making the carelessness of certain acts not so innocent as imagined, an aspect of place-making rarely alluded to. This is because the problem can't be seen with the naked eye so isn't that obvious, and because no 'thing' is perceived as being missing, the other possible visions having long since been forgotten, everything goes on as before. The status quo remains intact and undisturbed, making the purpose and impact of obliviousness clear however. Only upon waking up from this state of mind do people suddenly recognise what has been lost, that some form of injustice has taken place. Then the consciousness is raised that undemocratic practices are at hand prompting indignation and rage. The dozing ceases abruptly, and the people attempt to take back the reigns of control, but too late.

Having been unable to rouse themselves in time, the power has gone elsewhere with a simple slipping through the grasp, impossible now to regain. This shock realisation forces reconsideration, the need being to make a conscious choice between staying permanently in the background where it was safe, or picking a way through unfamiliar and sometimes hostile territory in the hope of regaining lost ground. The bolder approach is to raise expectations to even greater height, giving up all thoughts of escape through obliviousness. This act of leaping into the foreground of action shatters all possibility of indifference, apathy, or ignorance, and leads to resistance against forgetfulness and all other forms of carelessness. Although forgetting is an understandable practice, there being less shame in making a graceful exit than undertaking an unsuccessful endeavour, standing aside carries the greater risk. A person might end up being excluded for lack of response, with the result that they eventually get shut out of decision-making altogether out of sheer inertia. However, the reverse can also be true; that in taking too great an interest in proceedings a person's contributions may still be discounted particularly if they somehow fall foul of the general plan.

So rather than be made to feel unwelcome, even denigrated for our attempts to participate, many decide to just lie down in the shade and go to sleep, to accept gratefully whatever is on offer. This uncomplicated approach to life carries fewer demands, removing as it does the burden of thinking things through. And yet because of my stubborn insistence on creating a radical story about a park, this place has become tainted and turned into a veritable swamp. Doing so has allowed choice to return, but at a cost. Doubts have been raised and deep mistrust uncovered, destroying some cherished assumptions about urban parks. They no longer look quite such lovely concepts, being the bearers of disillusionment and disappointment in this case. In contemplating Waitangi Park, it seems now to embody the death of a nameless and shapeless hope, signalling the presence of a tale without end. 


\section{List of Illustrations}

\section{Page 2}

Illustration 1

Page 3

Illustration 2

Illustration 3

Illustration 4

Illustration 5

\section{Page 4}

Illustration 6

Illustration 7

\section{Page 5}

Illustration 8

Illustration 9
Waitangi Park, 2007.

Source: Author's collection.

Skateboarding, Waitangi Park.

Source: Wellington City Council,

On the Waterfront, Issue 30, May 2007.

'Subway opens on the waterfront'

Source: Wellington City Council,

On the Waterfront, Issue 30, May 2007.

Inside front cover, Wellington Waterfront: Looking Ahead.

Source: Wellington City Council, October 2003.

'Seaward promenade reopens'

Source: Wellington City Council,

On the Waterfront, Issue 30, May 2007.

Wellington (Port Nicholson), 1842.

Source: Carman, A.H. (1970) The Birth of a City.

Wellington: Wright \& Carman, frontispiece.

The Destructor with city morgue in foreground.

Source: McGill, David (2003) Wellington: A Capital Century.

Wellington: Transpress, p.30.

Corporation Yard, mid 1980s.

Source: Johnson, David (1996) Wellington Harbour.

Wellington: Wellington Maritime Museum Trust, p.411.

Caption: Chaffers Park, Wellington. A competition to redesign it.

Source: The Dominion Post Collection

Photographer: John Nicholson

Image ID: 73343

Filename: Chaffers_JN_AMJ_1903_73343.jpg

Published:

The Dominion Post - 22/3/2002

The Dominion Post - 7/10/2002 


\section{Page 6}

Illustration 10

Illustration 11

\section{Page 7}

Illustration 12

\section{Page 8}

Illustration 13

Illustration 14

\section{Page 9}

Illustration 15

Illustration 16

Illustration 17

\section{Page 10}

Illustration 18

Illustration 19
'Harbour City: Blueprints for the Future'.

Plans of winning entry by Paperchase Group,

Wellington Civic Trust, Harbour City Ideas Competition, 1982

Source: J.C. Beaglehole Room

The Library

Victoria University of Wellington

ID: NA 9282 W4 W776, p.8.

Lambton Harbour Group (1989) Lampton Harbour Combined Scheme: Under Town and Country Planning Act 1977: Appendix: Urban Design Concept. Gabites Porter \& Partners, Wellington.

Source: Lambton Harbour Management Limited March, 1989 (approximated date).

Tom Bollinger cartoon of Wellington waterfront.

Source: City Voice, 9 May 1996, p.18.

Members of the public study a model of proposed development to Wellington's waterfront.

Source: EP/2000/0285/32 [ca 28 January 2000]

Dominion Post Collection

Alexander Turnbull Library, Wellington, N.Z.

'Public already excluded', [commentary by Lindsay Shelton].

Source: The Dominion Post, 15 September 2007.

Chaffers development proposals viewed by concerned citizens.

Source: DOM/1996/0505/1/19 [ca 5 May 1996]

Dominion Post Collection

Alexander Turnbull Library, Wellington, N.Z.

'Parts of development will be unpleasant for public - report'.

Source: The Evening Post, 18 April 1996.

Artist's impression of Chaffers Crescent in the residential development. Source: The Dominion, 17 April 1996.

People seated at a waterfront development public forum, Queens Wharf Events Centre, Wellington.

Source: EP/1996/1464/21 [ca19 May1996]

Dominion Post Collection

Alexander Turnbull Library, Wellington, N.Z.

'Waterfront battle close to the edge'.

Source: The Dominion, 2 February 2000. 
Illustration $20 \quad$ Frances Williamson presents Mayor Mark Blumsky with a petition against Variation 17 of the Wellington City Council's district plan.

Source: EP/2000/0388/27 [ca 8 February 2000]

Dominion Post Collection

Alexander Turnbull Library, Wellington, N.Z.

\section{Page 11}

Illustration 21

Variation 17 meeting, Wellington. The controversial Variation 17 (to the WCC District Plan) proposed large scale commercial development of the waterfront.

Source: DOM/2000/0201/1/19 [ca 1 Feb 2000]

Dominion Post Collection

Alexander Turnbull Library, Wellington, N.Z.

Illustration 22 Mayor Mark Blumsky with Wellington City Councillors at a press

conference in which they discuss Variation 17 of the district plan. Shows

Councillors Rob Goulden, Kerry Leigh Prendergast (1953-),

Ian Hutchings, Allen Johnstone, Chris Parkin, Sue (Susan Margaret)

Piper (1951-), Robert Armstrong, and Alick Shaw (1952-).

Source: EP/2000/0375/33 [ca 7 February 2000]

Dominion Post Collection

Alexander Turnbull Library, Wellington, N.Z.

Illustration 23 'Five years' work at risk - Blumsky'

Source: The Dominion, 29 January 2000.

\section{Page 12}

Illustration 24

Caption: Outgoing Waterfront Watch chairman Lindsay Shelton with the Overseas Terminal in the background.

Source: The Dominion Post Collection

Image ID: 80842

Filename: waterfront_80842.jpg

Photographer: Kent Blechynden

The Dominion Post - 10/5/2004

The Dominion Post - 14/5/2004

Illustration 25 Caption: Lindsay Shelton, retiring from the NZ Film Commission as their Marketing Director.

Source: The Dominion Post Collection

Image ID: 58039

Filename: Shelton_3_pr_tom_010501_58039.jpg

Photographer: Phil Reid

The Dominion - 7/9/2001

The Dominion Post - 22/7/2003

Illustration 26 Lindsay Shelton, organizer of a protest meeting against Variation 17 of the Wellington City Council's district plan.

Source: EP/2000/0293/027 [ca 29 January 2000]

Dominion Post Collection

Alexander Turnbull Library, Wellington, N.Z. 


\section{Page 13}

Illustration 27

'Oppose New Buildings on Waitangi/Chaffers Park'.

Source: Waterfront Watch, leaflet, October 2005.

Illustration 28

'If you object to the way Lambton Harbour Management is behaving on your waterfront...'

Source: City Voice, 16 May 1996.

\section{Page 14}

Illustration 29

WCC advertisement encouraging public to post opinions to Lambton Harbour Consultation

Source: Special Lambton Harbour consultation edition, Have your say funding options, July 1997, p. 4

Illustration $30 \quad$ Waterfront Leadership Group.

Source: Wellington City Council, Waterfront Newsletter, Issue Three, 21 Sept 2000, p.3.

Illustration $31 \quad$ Waterfront Leadership Group Workshop.

Source: Wellington City Council, Waterfront Newsletter, Issue Four, 19 October 2000, cover.

\section{Page 15}

Illustration 32

Wellington City Councillor Mary Varnham (1946-) standing in the centre of Lambton Quay, Wellington. Varnham is suggesting that the street be closed to most vehicles in the lead up to Christmas.

Source: EP/1999/3425/20 [ca 10 November 1999]

Dominion Post Collection

Alexander Turnbull Library, Wellington, N.Z.

\section{Page 16}

Illustration 33 Chaffers Park Campaigners.

Source: City Voice, cover, 11 December 1997.

Illustration $34 \quad$ Filling out Chaffers development surveys, Wellington.

Source: DOM/1997/0814/1/20 [ca 14 Aug 1997]

Dominion Post Collection

Alexander Turnbull Library, Wellington, N.Z.

\section{Page 17}

Illustration 35

'365 Things To Do In a Park'

Source: City Voice, 28 August 1997, p.14.

Illustration 36 'Mary Varnham - indefatigable'

Source: City Voice, 18 December 1997. 


\section{Page 18}

Illustration 37

Illustration 38

Illustration 39
'Mary Varnham at Chaffers Park last year'.

Source: City Voice, 26 November 1998, p.4.

'Thousands Back Park'.

Source: City Voice, 23 September 1997, p.3.

'A great day at Chaffers Park'.

Source: Chaffers Park Make It Happen,

Newsletter 3, 5 September 1997, p.3.

\section{Page 19}

Illustration 40

Illustration 41

Illustration 42

\section{Page 20}

Illustration 43

Illustration 44

Illustration 45

Illustration 46

Illustration 47
'Lambton Harbour dream a nightmare', [commentary by Mary Varnham]. Source: The Evening Post, 9 May 1996.

'There's something about Mary', [campaign advertisement].

Source: City Voice, 15 October 1998, p.3.

"Public 'treated as fools' on Chaffers", [commentary by Mary Varnham]. Source: Contact, 12 March 1998.

Wellington City Council

Sketch of proposed Chaffers Park

Source: City Voice, 23 October, 1997, p.3.

Sketch of proposed Chaffers Park, Wellington City Council.

Source: City Voice, cover, 20 January 2000.

Sketch of Chaffers Park development.

Source: Wellington City Council,

Special Lambton Harbour consultation edition, July 1997, p.1.

"Chaffers Park and 'Herd Island' - the council's latest plan".

Source: City Voice, 10 December 1998, p.3.

Source: Wellington City Council

Option 4 - Chaffers Development, Concept Plan Proposal, Enclosure 1 (d)

Report 21: The Development of Chaffers Area of the Lambton Development Project, 9 December 1998.

Model of proposed buildings for Queens Wharf, Wellington.

Source: EP/2000/0180D/29 [ca 19 January 2000]

Dominion Post Collection

Alexander Turnbull Library, Wellington, N.Z. 
Illustration 48 Option 2 - Chaffers Development, Concept Plan Proposal, Enclosure (b)

Source: Wellington City Council

Report 21: The Development of Chaffers Area of the

Lambton Development Project, 9 December 1998.

\section{Page 21}

Illustration 49
Caption: M H Waterfront Project Manager Pennie Hurndell with some of the submissions for the Chaffers Park upgrade

Source: The Dominion Post Collection

Photographer: Maarten Holl

Image ID: 75050

Filename: waterfront2_mh_db_2204_75050.jpg

Published: The Dominion Post, 23 April 2002.

Illustration 50

Illustration 51

\section{Page 22}

Illustration 52

Illustration 53

\section{Page 23}

Illustration 54

Illustration 55

Illustration 56

\section{Page 24}

Illustration 57

Illustration 58
Designs on Chaffers, Rachel Hughes' Stage 1 proposal Chaffers Park.

Source: Wellington City Council, Your city council newspaper, APW, July 2002, p.10.

'Chaffers Park - get your thinking caps on...'.

Source: Wellington City Council, Your city council newspaper, undated, p.10.

Logo for Chaffers Park Design Competition.

Source: Wellington City Council, undated.

'Battle of the Chaffers designs'.

Source: Cook Strait Times, 2 December 2002.

'Just wait and see'.

Source: Wellington City Council,

A great new green on the waterfront, undated.

'Chaffers design decided: Experts override public's choice'.

Source: Cook Strait Times, 2 December 2002.

'Council wins park war'.

Source: The Dominion Post, 28 January 2004.

'Scheme A design challenged'.

Source: Cook Strait Times, 9 December 2002.

'Waterfront judges fail first big test'.

Source: The Evening Post, 31 May 2002. 


\section{Page 25}

Illustration 59

Illustration 60

Illustration 61

\section{Page 26}

Illustration 62

Illustration 63

\section{Page 27}

Illustration 64

Illustration 65
Getting Lambton Harbour Back on Track.

Source: WCC Special Lambton Harbour consultation edition, July 1997.

Caption: Mayor Kerry Prendergast and Fran Wilde on the waterfront's city- to-sea bridge.

Source: The Dominion Post

Image ID: 21244

Filename: watera 27244.jpg

Photographer: Rob Kitchin

Publishing Info:

The Dominion Post - 23/7/2003

\section{'Let's get on with it'}

Source: The Dominion Post, 23 July 2003, p.B5.

'A park rising from the rubble'.

Source: The Wellingtonian, 19 May 2005.

'Chaffers Park to be given new name'.

Source: The Dominion Post, 11 April 2003.

Caption: Rachel Hughes in her home in Seatoun Heights with her Chaffers Park proposal plans.

Source: The Dominion Post Collection Image ID: 55210

Filename: Chaffers_Hughes_6_552210.jpg.

Photographer: Haana Howard

Publishing info:

The Dominion Post - 23/5/2002.

Models of Chaffers Park Design Competition, Schemes B, C, D and E.

Source: Tag Report, pp.17-21.

Review of Chaffers Park Competition Stage 2

Wellington Waterfront Development Subcommittee

Technical Advisory Group,

Wellington City Council.

\section{Page 28}

Illustration 66

Scheme D model, Chaffers Park Design Competition.

Source: Collection of Rachel Hughes and Simon Novak.

Illustration 67 Children's playground, Waitangi Park.

Source: Wellington City Council,

On the Waterfront, Issue 18, 2006. 


\section{Page 29}

Illustration 68

Illustration 69

Illustration 70

\section{Page 30}

Illustration 71

Illustration 72

\section{Page 31}

Illustration 73

Illustration 74

Illustration 75

\section{Page 32}

Illustration 76

Illustration 77

\section{Page 33}

Illustration 78

Illustration 79
Scheme D model, Chaffers Park Design Competition.

Source: Collection of Rachel Hughes and Simon Novak.

Skateboard park, Waitangi Park, 2007.

Source: Author's collection.

Skateboard park, Waitangi Park, 2007.

Source: Author's collection.

Scheme D model, Chaffers Park Design Competition.

Source: Collection of Rachel Hughes and Simon Novak.

Waitangi Park, 2007.

Source: Author's collection.

Scheme D model, Chaffers Park Design Competition.

Source: Collection of Rachel Hughes and Simon Novak.

'In a mess: surrounded by construction work', [Futuna Chapel].

Source: The Dominion Post, 16 September 2002.

View looking north along graving dock, Waitangi Park, 2007.

Source: Author's collection.

Scheme D model, Chaffers Park Design Competition.

Source: Collection of Rachel Hughes and Simon Novak.

Waharoa (Maori Gateway), Waitangi Park, 2007.

Source: Author's collection.

'The Waterfront: The Facts', Wellington City Council.

Source: The Dominion, 26 January 2000, p.14.

Evaluation Scheme A

Source: Wellington City Council

Wellington Waterfront Development Committee,

Technical Advisory Group

Review of Chaffers Park Competition, Stage 2, 2002, p.11.

\section{Page 34}

Illustration 80
Scheme D, view looking west from marina.

Source: Collection of Rachel Hughes, Simon Novak. 
Illustration 81 Scheme A, view looking west towards Herd Street Building,

Waitangi Park, 2007.

Source: Author's collection.

\section{Page 35}

Illustration 82
Submission for Chaffers Park Design

Source: Wellington Branch of the New Zealand Institute of Landscape, Architects, Undated, c. late 2002.

\section{Page 36}

Illustration 83
Submission for Chaffers Park Design

Source: Wellington Branch of the New Zealand Institute of Architects, 12 November 2002.

\section{Page 37}

Illustration 84
Scheme D, view looking west.

Source: Collection of Rachel Hughes, Simon Novak.

Illustration 85 Scheme A, View from marina.

Source: Author's collection.

\section{Page 38}

Illustrations 86-89

Scheme D model, Chaffers Park Design Competition.

Source: Collection of Rachel Hughes, Simon Novak.

\section{Page 39}

Illustration 90

Caption: Finalist in the Chaffers Park design competition, Megan Wraight lead designer for this entry.

Source: The Dominion Post

Image ID: 7986

Filename: 1057_Megan_Wraight_7986.jpg

Photographer: Andrew Gorrie

Publishing Info:

The Dominion Post - 9/10/2002

Illustration 91 Caption: Finalist in the Chaffers Park design competition, Rachel Hughes lead designer for this entry

Source: The Dominion Post

Image ID: 7987

Filename: 1059_Rachel_Hughes_7987.jpg

Photographer: Andrew Gorrie

Publishing Info:

The Dominion Post - 9/10/2002

The Dominion Post - 30/10/2002

The Dominion Post - 21/11/2002 


\section{Page 40}

Illustration 92 View looking north over graving dock, Waitangi Park, 2007.

Source: Author's collection.

\section{Page 41}

Illustration 93 Night view of lit walkway near café, Waitangi Park, 2007.

Source: Author's collection.

\section{Page 42}

Illustration 94 View of Waitangi Park from Te Papa Museum, 2007.

Source: Author's collection.

\section{Page 43}

Illustration 95 ' 8 weeks to design quayside'

[Ian Athfield's involvement in WCC's waterfront redesign]

Source: City Voice, 17 July 1997, p.3.

Illustration 96 'Use of stormwater in park'

[Megan Wraight's involvement in WCC's design of Chaffers Park area]

Source: The Dominion, 2 February 2000, p.16.

\section{Page 47}

Illustration 97 'Lambton Harbour Consultation...the design team reports'

[Wellington City Council]

Source: City Voice, 16 October 1997.

\section{Page 48}

Illustration 98 'Town belt, walkways, playgrounds, beaches, parks, sportsfields...

What would you like to see?'

[Wellington City Council]

Source: City Voice, 30 July 1998.

\section{Page 49}

Illustration 99 'The Waterfront: The Facts'

[Wellington City Council]

Source: City Voice, 27 January 2000.

\section{Page 58}

Illustration 100 'Designs of Chaffers'

Source: Wellington City Council, Your city council newspaper, AOW, July 2002, p10.

\section{Page 59}

Illustration 101 'Wellington's New Waterfront Park'

Source: Wellington City Council, Splash Special, Autumn 2003, cover. 


\section{Page 61}

Illustration 102 'The Wraight Stuff'

Source: On the Waterfront, Issue 15, 2005.

\section{Page 72}

Illustration 103 Image of proposed Hilton hotel for Queens Wharf Outer-T.

Source: Absolutely Positively Wellington, Wellington City Council, Consultation, p.3, undated.

Illustration 104 Overseas Passenger Terminal.

Source: Wellington City Council

http://www.wellingtonwaterfront.co.nz/development/waitangi/overseas passenger_terminal/index.htm, accessed 4 January 2009.

\section{Page 87}

Illustration 105 Photograph by Eugene Atget, Grand Trianon, Pavillon de musique,

Source: Szarkowski, John and Maria Morris Hambourg (1983) The Work of Atget: The Ancien Regime, Volume III. London: Gordon Fraser, p. 53, plate 17.

Illustration 106 Municipal Gardens, Southport 1907.

Source: Woudstra, Jan and Ken Fieldhouse (2000) The Regeneration of Public Parks. London: E \&FN Spon, p.II: figure 3, colour section.

Illustration 107 Gymnasium and playground Stanford park Chicago South park, Outdoor District Annual Report c. 1915.

Source: Cranz, Galen (1982) The Politics of Park Design: A History of Urban Park in America. Cambridge, Massachusetts: MIT Press, p92.

\section{Page 88}

Illustration 108 Recreation facility New York City.

Source: Cranz, Galen (1982) The Politics of Park Design:

A History of Urban Park in America. Cambridge, Massachusetts:

MIT Press, p124.

Illustration 109 Playground in Picton, New Zealand.

Source: Author's collection.

\section{Page 89}

Illustration 110 Pocket park, Upper Hutt, New Zealand.

Source: Author's collection.

Illustration 111 Waterfront park, Melbourne, Australia.

Source: Author's collection. 
Illustration 112 Latz + Partner, Duisburg-Nord Landscape Park, Duisburg, Germany 1990-2002. [A park developed on the site of an old steelworks.]

Source: Reed, Peter (2005) Groundswell: Constructing the contemporary landscape. New York: The Museum of Modern Art, p.5.

\section{Page 90}

Illustration 113 Waterfront redevelopment, Bristol City, UK

Source: http://www.tripadvisor.com/LocationPhotos-g186220-w2-

Bristol_England.html\#17513936, accessed 11 January 2009.

\section{Page 91}

Illustration 114 Cannon's Marsh Amphitheatre, Cannon's Way, Bristol, City of Bristol, UK.

Source: http://static.panoramio.com/photos/original/18955.jpg, accessed 11 January 2009.

\section{Page 94-96}

Letter from Rachel Hughes to Wellington City Council concerning anomalies in Chaffers Park Design Competition, 10 December 2002.

\section{Page 97-98}

Letter of response to Rachel Hughes from David Kernohan, Chair, Waterfront Development Subcommittee, Wellington City Council, regarding anomalies in the Chaffers Park Design Competition, 19 December 2002.

\section{Page 102}

Illustration 115 Smaller pedestrian bridge spanning graving slip, western edge of Waitangi Park, 2007.

Source: Author's collection.

Illustration 116 Waitangi Park, Waitangi Day, 6 February 2008.

Source: Author's collection.

Illustration 117 Waitangi Park, Waitangi Day, 6 February 2008.

Source: Author's collection.

\section{Page 103}

Illustration 118 Signage system at night, eastern edge of Waitangi Park, 2007.

Source: Author's collection.

Illustration 119 Night view of open green and lit benches, Waitangi Park, 2007. Source: Author's collection.

Illustration 120 View looking north along graving dock, Waitangi Park, 2007. Source: Author's collection. 


\section{Page 104}

Illustration 121 'Whaharoa Unveiled in Waitangi Park'.

Source: On the Waterfront, Issue 24, 2006.

Illustration 122 Triathlon, Waitangi Park, 2007.

Source: Author's collection.

Illustration 123 Waitangi Park, Waitangi Day, 6 February 2008.

Source: Author's collection.

\section{Page 105}

Illustration 124 Waitangi Park from Herd Street Building, 2008.

Source: Author's collection.

Illustration 125 Seating on southern edge of Waitangi Park at dawn, 2007.

Source: Author's collection.

Illustration 126 Lit promenade near café kiosk, Waitangi Park, 2007

Source: Author's collection.

\section{Page 106}

Illustration 127 Waitangi Park, café kiosk, 2007.

Source: Author's collection.

Illustration 128 View of green, Waitangi Park, 2007.

Source: Author's collection.

Illustration 129 Waitangi Park, promenade leading to Herd Street Building, 2007.

Source: Author's collection.

\section{Page 107}

Illustration 130 Chaffers Park, Wellington. A competition to redesign it.

Source: The Dominion Post.

Filename: Chaffers_JN_AMJ_1903_73343.jpg

Photographer: John Nicholson

Published: The Dominion Post - 22/3/2002

The Dominion Post - 7/10/2002.

Illustration 131 Wellington (Port Nicholson), 1842.

Source: Carman, A.H. (1970) The Birth of a City.

Wellington: Wright \& Carman, frontispiece.

Illustration 132 Chaffers Beach, 1867/68.

Source: Stewart, Graham (1999) Around Wellington by Tram

in the $20^{\text {th }}$ Century. Wellington: Grantham House, p.22. 


\section{Page 108}

Illustration 133 Corporation Yard and Destructor from Clyde Quay.

Source: Wellington City Council Archives.

Neg. 00138:0:13462.

Illustration 134 Panoramic photograph of staff and machinery at Corporation Yard, Clyde Quay. Source: Wellington City Archives.

Neg. 00138:0:9164.

Illustration 135 Rolling crane, Wellington City Corporation Yard.

Source: Wellington City Archives.

Neg. 00146:1:99.

Illustration 136 Wakefield Street looking toward Destructor and Mount Victoria.

Source: Wellington Harbour Board (1980) The Wellington Harbour Board Collection. Wellington: Wellington Harbour Board, New Zealand, p.232.

\section{Page 109}

Illustration 137 Clyde Quay, in 1910, from Mount Victoria.

Source: McGill, David (2003) Wellington: A Capital Century.

Wellington: Transpress, p.30.

Illustration 138 Perspective View of Proposed Lay-Out of Corporation Yard,

Scheme B, 2 August 1949.

Source: Wellington City Council Archives

File: 00009:953:50/3/13 P +1.

Illustration 139 Cropped image of aerial view of Clyde Quay Wharf and Herd Street Post and Telegraph Building.

Source: McGill, David (2003) Wellington: A Capital Century.

Wellington: Transpress, p.180.

Illustration 140 Aerial view of Wellington City Corporation Yard.

Source: The Dominion, 28 June 1978.

\section{Page 110}

Illustration 141 'Before: Waitangi Park before construction began'.

Source: Wellington City Council.

On the Waterfront, Issue Four, August 2004.

Illustration 142 'A Space to Play'.

Source: City Voice, 18 April 1996, p28. 
Illustration 143 Rosamund Averton is angry about the potholes and general state of Chaffers Park.

Source: The Dominion Post Archives

File: Chaffers_Park_1_2535.jpg

Published, 9 August 2002

Photographer: Martin Hunter.

Illustration 144 File picture showing Chaffers Park which is undergoing redevelopment.

Source: The Dominion Post Archives

Filename: Chaffers_Park_1409_91898.jpg

Date Taken: 14 September 2004.

Photographer: Craig Simcox.

\section{Page 111}

Illustration 145 Aerial of Chaffers Park and the construction of Waitangi Park around the old Post and Telegraph Building on the waterfront, Wellington city.

Source: The Dominion Post Archives.

File: Chaffers 120011.jpg

Published: 30 June 2005

Photographer: Andrew Gorrie.

Illustration 146 Waitangi Park, opening display.

Source: Wellington City Council, On the Waterfront, Issue 18, 2006.

\section{Page 112}

Illustration 147 'Sleeping it off'

[These two guys were still recovering on New Years Day in Waitangi Park after a big night.]

Source: The Dominion Post Archives

Image ID: 213846

Filename: new_years_day_3_213846.jpg

Photographer: Andrew Gorrie

Publishing Info:

The Dominion Post - 5/1/2007

The Dominion Post - 2/1/2008. 


\section{References}

'Across the board' (editorial) Architecture New Zealand, Jan/Feb. 1998, pp.12-13.

Action for the Environment (1978) A Harbour View: A Public Opinion Survey of Wellington. Wellington: Action for the Environment.

Assessors' Report: Harbour City Competition, New Zealand Architect, No. 5, 1983, p.35-41.

Augé, Marc (2004) Oblivion. Minneapolis: University of Minnesota Press.

Bassett, Keith, Ron Griffiths and Ian Smith (2002) 'Testing Governance: Partnerships, Planning and Conflict in Waterfront Regeneration' in Urban Studies, 2002:39, pp.1757-1775. http://usj.sagepublcom/cigi/content/abstract/39/10/1757.

Bentley, Ian (1999) Urban Transformations: Power, people and urban design. London: Routledge.

Bergström, Lars (1970) 'What is a Conflict of Interest?' in Journal of Peace Research, 1970; 7; 197. http://jpr.sagepub.com/cgi/content/abstract/7/3/197.

Birchall, Clare (2006) Knowledge Goes Pop: From Conspiracy Theory to Gossip. N.Y.: Berg.

Blunt, Gerald, Chris McDonald, and Tommy Honey (2003) 'Battle of the Backyard' in Architecture New Zealand, Jan/Feb 2003, No. 1, pp.64-72.

Boin, Arjen, Allan McConnell, Paul 'T Hart (eds) (2008) Governing After Crisis: The Politics of Investigation, Accountability and Learning. Cambridge: Cambridge University Press.

Campos, J. Edgardo and Sanjay Pradhan (eds) (2007) The Many Faces of Corruption: Tracking Vulnerabilities at the Sector Level. Washington, DC: The World Bank.

Cannavò, Peter F. (2007) The Working Landscape: Founding, Preservation, and the Politics of Place. Cambridge, Massachusetts: The MIT Press.

Carman, A.H. (1970) The Birth of a City. Wellington: Wright \& Carman.

Castells, M. (1998) 'Conclusion: Making Sense of our World' in End of the Millennium. Oxford: Blackwell, pp.335-360.

Cohen, S. and Laurie Taylor (1976) Escape Attempts: The theory and practice of resistance to everyday life. London: Penguin.

Corrick, Martin (2008) By Chance. NY: Random House.

Cranz, Galen (1982) The Politics of Parks: A history of urban parks in America. Cambridge, Mass.: MIT Press. 
Cranz, Galen (1994) 'Four Models of Municipal Park Design in the United States' in Stuart Wrede and William Howard Adams (eds) Denatured Visions: Landscape and Culture in the Twentieth Century. New York: Museum of Modern Art, pp. 118-123.

Davies, Valerie (1994) The Way We Were: Wellington. Auckland: Moa Beckett Publishers.

De Man, Paul (1971) Blindness \& Insight: Essays in the rhetoric of contemporary criticism. New York: Oxford University Press.

Doorne, Stephen Michael (1998) 'Power, Participation and Perception: An Insiders' Perspective on the Politics of the Wellington Waterfront Redevelopment', Current Issues in Tourism, Vol. 1, No. 2, 1998. Discussion Web Site: http://divcom.otago.ac.nz:800/tourism/currentissues/homepage.htm. Accessed 15 December 2007.

Doorne, Stephen Michael (1998) The last resort: a study of tourism policy, power and participation on the Wellington waterfront : a thesis submitted to the Victoria University of Wellington in fulfilment of the requirements for the degree of Doctor of Philosophy in Tourism and Services Management. Victoria University of Wellington.

Dovey, Kim (2005) Fluid City: Transforming Melbourne's Urban Waterfront. Abingdon, Oxfordshire: Routledge.

Edy, Jill A. (2001) 'The Presence of the Past in Public Discourse' in Roderick P. Hart and Bartholomew H. Sparrow (eds) Politics, Discourse, and American Society: New Agendas. New York: Rowman \& Littlefield, pp. 53-70.

Edwards, Doug (1989) Put Him In The Longboat. Wellington Harbour Board / Government Printing Books.

Evans, Graeme (2005) 'Measure for Measure: Evaluating the Evidence of Culture's contribution to Regeneration' in Urban Studies, 2005; 42; 959-983.

http://usj.sagepub.com/cgi/content/abstract/42/5-6/959.

Fukuyama, Francis (ed) (2007) Blindside: How to anticipate forcing events and wild cards in global politics. Baltimore, MD: Bookings Institution Press.

Glazer, Nathan (2007) From a Cause to a Style: Modernist Architecture's Encounter with the American City. Princeton, NJ: Princeton University Press.

Green, Suzanne (2002) 'Chaffers on show' in Landscape New Zealand, Nov/Dec., pp.46-49.

Guterbock, Thomas M. (1980) 'Sociology and the Land-Use Problem' in Urban Affairs Review, 1980: 15; 243. http://uar.sagepub.com/cgi/content/abstract/15/3/243.

Haan, Hilde and Ids Haagsma with essays by Dennis Sharp and Kenneth Frampton (1988) Architects in Competition. London: Thames and Hudson.

'Harbour city competition', New Zealand Architecture, No.5, 1983, pp. 35-41.

Hayden, Dolores (1997) The Power of Place: Urban Landscapes as Public History. Cambridge, Massachusetts: MIT Press. 
Higonnet, A (2002) 'What do you want to know about children' in Marilyn Brown (ed) Picturing Children: Construction of Childhood between Rousseau and Freud. Aldershot, Hants: Ashgate, pp.200-206.

Hunt, John (1995) 'Design and detection: The strange case of the design competition' in Architecture New Zealand, Jan/Feb. 1995, pp.43-47.

Hunt, John (2005) 'Contested sites' in Architecture New Zealand, July/August 2005, pp.82-83.

Huxley, Aldus (1961) The Doors of Perception and Heaven and Hell. Harmondsworth, Middlesex: Penguin.

Johns, Ralph (2002) 'Wellington waterfront so far so good' in Landscape New Zealand, Jan/Feb. 2002, pp.12-15.

Johns, Ralph, (2006) 'A shore thing' in Landscape New Zealand, August 2006, pp.6-8.

Johnson, David (1996) Wellington Harbour. Wellington: Wellington Maritime Museum Trust.

Landscape New Zealand (2008) 'Award of Excellence for Sustainability: Wraight Athfield Landscape + Architecture Ltd, Waitangi Park, Wellington’, May 2008, p.11.

Le Heron, Richard and Eric Pawson (eds) (1996) Changing Places: New Zealand in the Nineties. Auckland: Longman Paul.

Marcus, Greil (1997) The Dustbin of History. London: Picador.

McCarthy, Christine (2003) 'Design Awards and Competitions' in Christine McCarthy and Jillian Walliss (eds.) Proceedings of National Design Research Symposium. Wellington: National Design Research Symposium 2003, Victoria University of Wellington, pp.76-81.

McGill, David (2003) Wellington: A Capital Century. Wellington: Transpress.

McGlynn, Sue (1993) 'Reviewing the Rhetoric' in Richard Hayward and Sue McGlynn (eds) Making Better Places: Urban Design Now. London: Butterworth-Heinemann, pp.3-9.

McQuillan, Martin (2001) Paul de Man. London and New York: Routledge.

Moodie, Graeme C. and Gerald Studdert-Kennedy (1970) Opinions, Publics and Pressure Groups. London: George Allen and Unwin Ltd.

Nancy, Jean-Luc (1993) The Birth to Presence. Stanford, CA: Stanford University Press.

New Zealand Institute of Architects (199[-]) Handbook for the Organization of Architectural Design Competitions. Auckland: NZIA.

O’Neill, Onora (2002) A Question of Trust. Cambridge: Cambridge University Press.

Park, Geoff (2007) 'The remnant ecologies of Waitangi Park' in Forest \& Bird, August, p36-37. 
Price, Nina (2007) Waitangi Park: Setting the Context, Honours Sociology paper, unpublished, School of Social and Cultural Studies, Victoria University of Wellington.

Reed, Peter (2005) Groundswell: Constructing the contemporary landscape. New York: The Museum of Modern Art.

Roberts, John (1989) Te Aro Pa: Its Significance. Wellington: John Roberts.

Sloan, T.S. (1986) Deciding: Self-Deception in Life Choices. New York: Methuen \& Co.

Smaldone, David, Charles Harris \& Nick Sanyal (2005) 'An exploration of place as a process: The case of Jackson Hole, WY', Journal of Environmental Psychology, No.25, pp.397-414.

Spreiregen, Paul D. (1979) Design Competitions. New York: McGraw-Hill.

Strong, Judith (1976) Participating in Architectural Competitions: A Guide for Competitors, Promoters and Assessors. London: The Architectural Press Ltd.

Strong, Judith (1996) Winning by design: architectural competitions. Boston: ButterworthHeinemann.

Stewart, Graham (1999) Around Wellington by Tram in the $20^{\text {th }}$ Century. Wellington: Grantham House.

Szarkowski, John and Maria Morris Hambourg (1983) The Work of Atget: The Ancien Regime, Volume III. London: Gordon Fraser.

Trudeau, Daniel (2006) 'Politics of belonging in the construction of landscapes: place-making, boundary-drawing and exclusion' in Cultural Geographies, No. 13; 421. http://cgj.sagepub.com/cgi/content/abstract/13/3/421.

Verdi, Laura (2004) 'The Garden and the Scene of Power' in Space and Culture, Vol. 7, No. 4, pp.360-385. http://sac.sagepub.com/cgi/content/abstract/7/4/360

Ward, Louis E. (1975) Early Wellington. Wellington: Whitcombe \& Tombs.

Ware, Glenn T., Shaun Moss, J. Edgardo Campos, and Gregory P. Noone (2007) 'Corruption in Public Procurement: A Perennial Challenge' in J. Edgardo Campos and Sanjay Pradhan (eds) (2007) The Many Faces of Corruption: Tracking Vulnerabilities at the Sector Level. Washington, DC: The World Bank, pp. 295-334 [hard copy version].

Wellington Harbour Board (1980) The Wellington Harbour Board Collection. Wellington: Wellington Harbour Board, New Zealand.

Wilson, Lyn (2003) Enchanted Forests and Themed Gardens: exploring a French intervention for Wellington, undergraduate design paper, unpublished, School of Architecture and Design, Victoria University of Wellington.

Wittig, Wayne A. (2005) 'Linking Islands of Integrity to Promote Good Governance in Public Procurement: Issues for Consideration' in Fighting Corruption and Promoting Integrity in Public Procurement. Paris: OECD, pp.109-114. 
Woudstra, Jan and Ken Fieldhouse (2000) The Regeneration of Public Parks. London: E \&FN Spon.

Yska, Redmer (2006) Wellington. Wellington: Reed.

Leaflets, inserts, advertisements (alphabetically)

Wellington City Council/Lambton Harbour Management Limited/Wellington Waterfront Limited

Absolutely Positively Wellington, Consultation, p.3, undated.

'Chaffers Park - get your thinking caps on...'.

Your city council newspaper, undated, p.10.

'Consultation: Proposed hotel for Queens Wharf Outer-T', undated.

'Designs on Chaffers', AOW, July 2002.

'Getting Lambton Harbour back on track', Special Lambton Harbour consultation edition, July 1997.

'Just wait and see, A great new green on the waterfront', undated.

'Lambton Harbour Consultation...the design team reports', 16 October 1997.

Special Lambton Harbour consultation edition, Have your say funding options, July 1997.

'The Waterfront: The Facts', City Voice, 20 January 2000.

'Town belt, walkways, playgrounds, beaches, parks, sportsfields... What would you like to see?', City Voice, 30 July 1998.

'Update on Lambton Harbour', Wellington City Council, May 1996.

‘Waitangi Park: Wellington's new waterfront playground', December 2004.

'Wellington's new waterfront playground: Waitangi Park:', December 2004.

'Wellington's Waterfront: A new urban park for Wellington', The Dominion Post, 2 August 2003.

'Wellington Waterfront: Looking Ahead', October 2003.

Letters and e-mails (by date)

Letter from Winifred E. Wright to Mayor of Wellington, 29 May 1964. Wellington City Archives, File: 00009:953:50/3/13 Pt 1, 1933-1965. 
Submission regarding Chaffers Park Development Plan sent to Wellington City Council by the New Zealand Institute of Architects, 12 November 2002.

Two draft submissions to Wellington City Council regarding Chaffers Park Design, e-mailed by the Wellington Branch of the New Zealand Institute of Landscape Architects to its membership, commenting on the merits of Scheme D's proposal, November 2002.

Final submission regarding Chaffers Park Design sent to Wellington City Council by Wellington Branch of the New Zealand Institute of Landscape Architects, 16 November 2002.

\section{Newsletters (by date)}

Chaffers Park - Make it Happen!

Chaffers Park Campaign - Newsletters, letters, and press releases.

http://www.sustainable.wellington.net.nz?Campaigns/Chaffers Park/, accessed 13 March 2008.

Submisssion to the Lambton Harbour Consultation, August 1, 1997.

'A great day at Chaffers Park', Newsletter 3, 5 September, 1997.

Newsletter 4, 16 October 1997.

Chaffer's Park Campaign - Letters and press releases, 21, October 1997.

Newsletter 5, November 11, 1997.

Newsletter 6, 27 February 1998.

'Public consultation a mockery', February 20, 1998.

'Variation 17 - It's a violation, not a variation', 7 February 2000.

'Blumsky's Folly', Fax dated 12 October 2000.

'Stop! Don't throw away Wellington's last chance for a large, beautiful green park of the waterfront', undated. Wellington City Archives, Waterfront Watch files, 2006/20 and 21 series.

'The great wall of Wellington', undated.

Waterfront Watch http://www.waterfrontwatch.org.nz/

No. 31, March-April 2000.

No. 32, May-June 2000.

No. 33, August, 2000.

No. 34, September 2000.

No. 36, February-March 2001. 
No. 37, April-May 2001.

No. 38, August 2001.

No. 40, December 2001.

No. 41, March 2002.

No. 42, April 2002.

No. 43, June 2002.

No. 44, September-October 2002.

No. 45, November 2002.

No. 46, December 2002.

Wellington City Council

'Waterfront Newsletter'

Issue One, 24 July 2000.

Issue Two, 30 August 2000.

Issue Three, 21 Sept 2000.

Issue Four, 19 October 2000.

Issue Five, 5 December 2000.

Issue Six, 19 December 2000.

Issue Seven, 20 February 2000.

Issue Eight, 15 March 2001.

Issue Nine, 7 May 2001.

Issue Ten, 21 June 2001.

Issue Eleven, 20 August 2001.

Issue Twelve, 21 September 2001.

Issue Thirteen, 29 October 2001

Issue Fourteen, 19 December 2001.

Issue Fifteen, 3 April 2002.

Issue Sixteen, 17 June 2002.

Issue Seventeen, 21 August 2002.

Issue Eighteen, 23 October 2002.

'Splash! The waterfront'

'Wellington's New Waterfront Park', Splash Special, Autumn 2003.

'On the Waterfront'

Issue 1, May 2004.

Issue 2, June 2004.

Issue 3, July 2004.

Issue 4, August 2004.

Issue 10, May 2005.

Issue 14, October 2005.

Issue 15, November 2005.

Issue 18, March 2006.

Issue 24, October 2006.

Issue 29, April 2007.

Issue 30, May 2007.

http://www.wellingtonwaterfront.co.nz/media_section/Publications/on the waterfront/ne wsletters.htm? $\mathrm{m}=40$ 
Wellington Civic Trust

http://www.wellingtoncivictrust.org/about/

July, 1983.

July, 1997.

September, 1997.

May, 1998.

October, 1998.

December, 1998.

May 23 1999, Annual General Meeting.

September, 1999.

July, 2001.

October, 2001.

March, 2002.

\section{Newspapers (by date)}

\section{City Living}

'A non event?', 7 December 1995.

\section{City Voice}

'Harbour Protest', 22 February 1996.

'Wanted a vision', 14 March 1996.

'The Waterfront: can we trust Lambton Harbour Management?', 18 April 1996.

'A space to play?', 18 April 1996 [commentary by Simon Collins].

'Informed debate welcomed', Chairman of Lambton Harbour Management, 9 May 1996

[commentary by Malcolm Woods].

'If you object to the way Lambton Harbour Management is behaving on your waterfront...', 16 May 1996.

'A foundering flagship', 16 May 1996 [commentary by Chris McDonald].

"Waterfront 'for people, not profits"', 23 May 1996.

'The waterfront: a re-designed process', 30 May 1996.

'Lambton Harbour mismanagement', 8 August 1996 [commentary by Alastair Thompson].

'New waterfront plan almost ready', 27 March 1997 [commentary by Simon Collins].

'Wellington's waterfront - a vision betrayed', 26 June 1997 [commentary by Derek Wilson].

'Creed of the cancer cell', 3 July 1997 [commentary by Derek Wilson].

'The state of our civilisation', 10 July 1997 [commentary by Derek Wilson].

'Lambton Harbour twists consultation process', 10 July 1997.

'Lambton Harbour: Decision time', 17 July 1997 [commentary by Ian Hunter, Chairman, Wellington Civic Trust].

'Eight weeks to design quayside', City Voice, 17 July 1997.

'Campaign for bigger Chaffers Park', 24 July 1997.

'Don't throw away Wellington's last chance for a large, beautiful green park on the waterfront', 7 August 1997.

'365 Things To Do In a Park', 28 August 1997.

'Big city park at Chaffers a step closer', 3 September 1997.

'Park Life', 18 September 1997.

'Thousands Back Park', 25 September 1997.

'Consultation axed', 9 October, 1997.

'Lambton Harbour Consultation...the design team reports', Wellington City Council, 16 October 1997. 
Sketch of proposed Chaffers Park, 23 October, 1997.

'Wall of buildings' opposed, 30 October 1997.

'Dysfunctional city?', 20 November 1997.

'Our Waterfront', 27 November 1997.

'Chaffers Park Campaigners', 11 December 1997.

'Throwing herself into the cause', 18 December 1997.

'Mary Varnham - indefatigable', 18 December 1997.

'Claim the city', 29 January 1998.

'Chaos reigns again on waterfront', 12 March 1998.

'Town belt, walkways, playgrounds, beaches, parks, sportsfields... What would you like to see?', Wellington City Council, 30 July 1998.

"Candidates claim 'lies' over Chaffers Park", 24 September 1998.

'Chaffers needs buildings' 26 November 1998 [commentary by Julia Gatley of the Wellington Architectural Centre].

'Waterfront test for council', 26 November 1998.

'Mary Varnham at Chaffers Park last year', 26 November 1998.

'Bleak park?', 3 December 1998 [commentary by Mary Varnham].

"Chaffers Park and 'Herd Island' - the council's latest plan”, 10 December 1998.

'Council in a mess', 1 April 1999.

'Waterfront slowdown urged', 29 April 1999.

'War on the waterfront' Latest scheme reopens divisions, 19 January 2000.

'The Waterfront: The Facts', Wellington City Council, 20 January 2000.

Sketch of proposed Chaffers Park, Wellington City Council, cover, 20 January 2000.

'Waterfront farce', 20 January 2000.

'Tidal wave against waterfront plans', 20 January 2000.

'The Waterfront: The Facts', 27 January 2000.

"No compromise on harbour", 27 January 2000.

'Aux armes, citoyens!', 10 February 2000.

'Garden in waiting', 24 February 2000.

'Blumsky to block democracy', 29 June 2000.

'Democracy poisoned', 13 July 2000.

“Applause greets 'no' to waterfront buildings", 19 October 2000.

\section{Contact}

'Right questions not asked', 25 August, 1989.

"Public 'treated as fools' on Chaffers", 12 March 1998 [commentary by Mary Varnham].

“"Councillors' choice for Chaffers Park”, 9 January 2003.

\section{Cook Straight Times}

'Battle of the Chaffers designs', 2 December 2002.

'Chaffers design decided: Experts override public's choice', 2 December 2002.

'Scheme A design challenged', 9 December 2002.

\section{The Dominion}

'Clyde Quay Area: Improvements Effected and in Prospect', 11 November 1937.

'Eyesore Soon May Go', 13 February 1965.

'Aerial view of Wellington City Corporation Yard', 28 June 1978.

'City plans \$40m. facelift for three acres', 28 June 1978.

'On the Waterfront', weekend section, 18 November 1995.

'Artist's impression of Chaffers Crescent in the residential development', 17 April 1996.

'Integrated view of Chaffers Bay plan urged', 17 April 1996. 
'Thinking big on the harbour', 15 and $16^{\text {th }}$ May 1996 [commentary by Lindsay Shelton].

'Another look at waterfront', 21 May 1996.

'Waterfront dilemmas', 24 July 1996.

'Attack on Lambton planning', 13 May 1997.

'Buildings not parks urged for waterfront', 14 August 1997.

'Chaffers site the key issue at council meeting', 15 August 1997.

'Guidelines set for Chaffers', 16 August 1997.

'Council votes for buildings on Chaffers site', 5 March 1998 [commentary by Paul Moran].

"Council waterfront plans 'take people by surprise", 13 January 2000 [commentary by

Lindsay Shelton].

'Harbour plan gets a rough ride', 14 January 2000 [commentary by Leah Haines].

'A better public space', 19 January 2000 [commentary by Mark Blumsky].

'Details please', 22 January 2000.

'Foreshore is public space', 22 January 2000.

'Mayor let us down', 24 January 2000.

'The Waterfront: The Facts', Wellington City Council, 26 January 2000, p.14.

'Five years' work at risk - Blumsky', 29 January 2000.

'Waterfront protest packs town hall', 2 February 2000.

'Waterfront battle close to the edge', 2 February 2000.

'Use of stormwater in park' by Megan Wraight, 2 February 2000.

'Wrestling on the waterfront', 15 February 2000.

'Chaffers Park design contest', 13 December 2001.

'Varnham seeks waterfront job', 27 February 2002.

'Part-timer has big plans for city park', 23 May 2002.

\section{The Evening Post}

'Corporation Yard Move Would Free Six Acres of Valuable Land', 11 June 1957.

'Big Redevelopment Plan for City Council's Yard in City is Approved', 17 August 1972.

'Fighting through the tack to get to the water', 17 August 1995 [commentary by Mary Varnham].

'Casino's long game of chance begins', 1 April 1996.

'Parts of development will be unpleasant for public - report', 18 April, 1996.

'Lambton Harbour dream a nightmare', 9 May 1996 [commentary by Mary Varnham].

'Debate encouraged but let's get facts right', 17 May 1996 [commentary by

Malcolm Woods, Chairman Lambton Harbour Management].

'Time to pause - Blumsky: Wellington Waterfront Forum', 20 May 1996.

'Council to discuss waterfront', 20 May 1996.

'The common theme: put people first', 28 May 1996.

'Chaffers must become a true city park', 15 December 1996 [commentary by Mary Varnham].

'Big city park at Chaffers a step closer', 3 September 1997.

'Varnham in election', 26 August 1998.

'There's something about Mary', 15 October 1998 [campaign advertisement].

'New council must have eye on future', 12 November 1998.

'War on the Waterfront: Latest scheme reopens divisions: The council claims the development will draw people to the waterfront. Opponents say Wellingtonians don't want it', 19 January 2000.

'Hundreds rally against harbour plan: MPs join the call against proposal', 28 January 2000. 
'Constitutional issues in Variation 17 dispute', 28 January 2000 [commentary by Mary Varnham].

'Hundreds rally against harbour plan', 28 January 2000.

'Up In Arms', EP Magazine, 29 January 2000.

'Objections run hot over waterfront', 29 January 2000.

'Call to stand firm on waterfront, 29 January 2000.

'Councillors ready for waterfront row', 31 January 2000.

'Full house expected in fight against Variation 17', 1 February 2000.

'Stop the Wall', 2 February 2000.

'Smokescreen on the waterfront', 5 February 2000 [commentary by Stuart Niven].

'Backlash sinks harbour plan', 7 February 2000.

"Council's 'middle way' is meaningless, say opponents", 8 February 2000.

'Sombre council pulls Variation 17 plug', 14 April 2000.

'Chaffers' future inspires designers', 19 April 2000.

'Waterfront decision a con -Varnham', $3^{\text {rd }}$ Ed., 12 August 2000.

'Chronology of waterfront developments', $2^{\text {nd }}$ Ed., 21 April 2001.

'Varnham throws hat in mayoral ring', 20 August 2001.

'Another waterfront battle brews', 4 September 2001.

'Design contest for Chaffers', 26 November 2001.

'Design brief for Chaffers Park', 11 December 2001.

'Ambulance building stays put - court', 13 December 2001.

'People don't want Chaffers buildings, watchdog warns', $3^{\text {rd }}$ Ed., 30 January 2002.

'Queue for Chaffers', 22 March 2002.

'Chaffers' future inspires designers', 19 April 2002.

'Is nothing safe from the bulldozer mentality?, 11 May, 2002.

'Blind eye to public in Chafers designs', 21 May 2002.

'Oscar winner fails to make park design cut', 25 May 2002.

'Waterfront judges fail first big test', 31 May 2002.

The Dominion Post

'Rosamund Averton is angry about the potholes and general state of Chaffers Park', 9 August 2002

'In a mess: surrounded by construction work', 16 September 2002 [Futuna Chapel].

'Futuna shift one idea for Chaffers', 9 October 2002.

'Park design plans at a glance. Five design proposals which have been shortlisted for

Chaffers Park. The winner will be chosen next month', 9 October 2002.

'Park design favourite chosen', 16 October 2002.

'Park design is a winner', 30 October 2002.

'Call to keep Chaffers simple', 8 November 2002.

'Park backers deny dirty tricks', 21 November 2002.

"“Chaffers debate: 'Listen to the people"”, 23 November 2002.

'Crunch time for Chaffers Park site', 25 November 2002.

'Experts' plan gets Chaffers nod', 26 November 2002.

'Waterfront Watch to meet over Chaffers decision', 27 November 2002.

'The architect says thanks', 6 December 2002.

'What people want and why they don't get it', 20 January 2003 [commentary by Lindsay Shelton].

'Waterfront decisions', 20 February 2003 [commentary by David Kernohan].

'Chaffers Park to be given new name', 11 April 2003.

'Park building plan faces fight', 5 May 2003.

'Chaffers park area approved', 13 May 2003. 
'Chaffers Park show', 24 May 2003.

'Cynicism not too surprising', 11 June 2003.

'Who can we trust?', 19 July 2003.

'Shore to rise', 19 July 2003.

'Waterfront warriors, 22 July 2003.

'Let's get on with it', 23 July 2003.

'Taking a stroll into the future', 25 July 2003.

'Who can you trust with the waterfront?', 26 July 2003.

'Wellington's Waterfront: A new urban park for Wellington', 2 August 2003.

'Farewell for Chaffers Park', 23 October 2003.

'Group attacks park sewage plans', 2 ${ }^{\text {nd }}$ Ed., 17 November 2003.

'Council wins park war', 28 January 2004.

'Waterfront Watch 'spoilers' - Wilde', 30 April 2004.

'Council under fire again', 10 May 2004.

'Park project taking shape', 16 March 2005.

'Suits fly as park builder digs up dirt', 26 May 2005.

'Aerial of Chaffers Park and the construction of Waitangi Park around the old Post and Telegraph Building on the waterfront, Wellington City', 30 June 2005.

'Waterfront's tarnished jewel', 10 December 2005.

'Public already excluded', 15 September 2007 [commentary by Lindsay Shelton].

"“End of the line' for Hilton on waterfront", 10 April 2008.

'Council wants your opinion', 1 May 2008.

'Waterfront appeal', 27 May 2008.

'Cloud over waterfront plans: Council feels pinch after hotel vetoed', 17 June 2008.

'Why the council secrecy?', 28 August 2008.

"RMA changes may go 'too far"”, 4 February 2009.

The National Business Review

'Controversy over capital's new urban park', 29 November 2002.

The Sunday Star Times

'Mayor backs off seafront plan', 30 January 2000.

'Nats ready controversial RMA planning shakeup', 1 February 2009.

The Wellingtonian

'A park rising from the rubble', 19 May 2005.

\section{Plans}

Lambton Harbour Management Limited,

Pictorial sales brochure for Chaffers Bay residential units, (undated).

\section{Reports (by date)}

Wellington City Council/Lambton Harbour Management Limited/Wellington Waterfront Limited. Lambton Harbour Group (1989) Lampton Harbour Combined Scheme: Under Town and Country Planning Act 1977: Appendix: Urban Design Concept. Gabites Porter \& Partners, Wellington. 
Lambton Harbour Management Limited (1989) Lampton Harbour Development Project. Wellington: Lambton Harbour Management Limited.

Lambton Harbour Management Limited (1990) A Place for People: Lambton Harbour Development Moves into the 1990s. Wellington: Lambton Harbour Management Limited.

Lambton Harbour Community Consultative Committee Review (1996) Report on Lampton Harbour.

Lambton Harbour Community Consultative Committee (1997) Public Consultation on the Waterfront Designs: Report from the Lambton Harbour Community Consultative Committee.

Special Lambton Harbour consultation edition, July 1997.

Report 21: The Development of Chaffers Area of the Lambton Development Project, 9 December 1998.

The Wellington Waterfront Framework (April 2001): Report of the Waterfront Leadership Group.

Wellington Waterfront Development Subcommittee

Assessment of Chaffers Design Competition Entries, 20 May 2002.

ACNielsen, Chaffers Design Competition, November 2002.

Results of Public Consultation on Chaffers Design Competition Finalists, Report 3, 25 November 2002.

Chaffers Park Design Competition winner selection, Report 4, 25 November 2002.

Technical Advisory Group

Review of Chaffers Park Competition, Stage 2, 18 November 2002.

Power point presentation of Review of Chaffers Park Competition, Stage 2.

Evaluation of Waitangi Park - A Qualitative Study, April 2007.

Waitangi Park Design Quality Audit, 14 June 2007.

Review of Waitangi Park, Report 6, 22 August 2007.

Wellington Waterfront General Users Survey, by UMR Research, April 2008.

Wellington Civic Trust

Wellington Civic Trust 1982/3, Harbour City: New Ideas for One of Wellington's Finest Assets.

Wellington Civic Trust (1983) Harbour City: Blueprints for the Future; Winning Entries in the Wellington Civic Trust Harbour City Competition. Wellington: Wellington Civic Trust.

Wellington Civic Trust (1984) Harbour City: Ideas for Action: Proceedings of the Harbour/City Conference, 4-5 July. 
Wellington Civic Trust (1996) On the Waterfront: A Report and Commentary on the Lambton Harbour Forum held at the Events Centre, Lambton Harbour, Sunday 19 May. Wellington: Wellington Civic Trust.

Brooks, Peter (1999) Public Consultation and the Waterfront: An Account, based on the records of the Wellington Civic Trust, of the public consultations undertaken by the Wellington City Council in 1996-97 on the development of the waterfront. Wellington: The Wellington Civic Trust, May 1999.

\section{Video}

Wellington City Council [video] Chaffers Design Competition (2003).

\section{Websites}

Canon's Marsh Amphitheatre, Cannon's Way, Bristol, City of Bristol, UK.

http://static.panoramio.com/photos/original/18955.jpg, accessed 11 January 2009.

Waterfront redevelopment, Bristol City, UK.

http://www.tripadvisor.com/LocationPhotos-g186220-w2-Bristol_England.html\#17513936, accessed 11 January 2009.

Wellington City Council

www.wellington.govt.nz

Overseas Passenger Terminal

http://www.wellingtonwaterfront.co.nz/development/waitangi/overseas

passenger_terminal/index.htm, accessed 4 January 2009.

'International line-up for next Chaffers design stage', 21 May 2002.

http://www.wellington.govt.nz/news/display-item.php?id+1043, accessed 11 September 2007.

'Possible Chaffers designs to be revealed', 16 May 2002.

http://www.wellington.govt.nz/news/display-item.php?id+1043, accessed 12 May 2007.

'Chaffers designs open to public feedback', 4 October 2002.

http://www.wellington.govt.nz/news/display-item.php?id+1043, accessed 11 September 2007.

'Waitangi Park Site Blessing' [News release] 2004. http://www.wellingtonwaterfront.co.nz/media_section/news_releases/news_releases_2004, accessed 17 February 2008. 